\title{
CONTROLLING INTAKE OF URANIUM IN THE WORKPLACE: APPLICATIONS OF BIOKINETIC MODELING AND OCCUPATIONAL MONITORING DATA
}

January 2012

Prepared by

R. W. Leggett ${ }^{1}$, K. F. Eckerman ${ }^{1}$, C. W. McGinn ${ }^{1}$, R. A. Meck ${ }^{2}$

${ }^{1}$ Environmental Sciences Division

Oak Ridge National Laboratory

P.O. Box 2008

Oak Ridge, TN 37831-6153

${ }^{2}$ Science and Technology Systems, LLC

9408 Corsica Drive

Bethesda, MD 20814-2814 


\section{DOCUMENT AVAILABILITY}

Reports produced after January 1, 1996, are generally available free via the U.S. Department of Energy (DOE) Information Bridge.

Web site http://www.osti.gov/bridge

Reports produced before January 1, 1996, may be purchased by members of the public from the following source.

National Technical Information Service

5285 Port Royal Road

Springfield, VA 22161

Telephone 703-605-6000 (1-800-553-6847)

TDD 703-487-4639

Fax 703-605-6900

E-mail info@ntis.gov

Web site http://www.ntis.gov/support/ordernowabout.htm

Reports are available to DOE employees, DOE contractors, Energy Technology Data Exchange (ETDE) representatives, and International Nuclear Information System (INIS) representatives from the following source.

Office of Scientific and Technical Information

P.O. Box 62

Oak Ridge, TN 37831

Telephone 865-576-8401

Fax 865-576-5728

E-mail reports@osti.gov

Web site http://www.osti.gov/contact.html

This report was prepared as an account of work sponsored by an agency of the United States Government. Neither the United States Government nor any agency thereof, nor any of their employees, makes any warranty, express or implied, or assumes any legal liability or responsibility for the accuracy, completeness, or usefulness of any information, apparatus, product, or process disclosed, or represents that its use would not infringe privately owned rights. Reference herein to any specific commercial product, process, or service by trade name, trademark, manufacturer, or otherwise, does not necessarily constitute or imply its endorsement, recommendation, or favoring by the United States Government or any agency thereof. The views and opinions of authors expressed herein do not necessarily state or reflect those of the United States Government or any agency thereof. 


\section{CONTROLLING INTAKE OF URANIUM IN THE WORKPLACE: APPLICATIONS OF BIOKINETIC MODELING AND OCCUPATIONAL MONITORING DATA}

January 2012

Prepared by

R. W. Leggett ${ }^{1}$, K. F. Eckerman ${ }^{1}$, C. W. McGinn ${ }^{1}$, R. A. Meck ${ }^{2}$

${ }^{1}$ Environmental Sciences Division

Oak Ridge National Laboratory

P.O. Box 2008

Oak Ridge, TN 37831-6153

${ }^{2}$ Science and Technology Systems, LLC

9408 Corsica Drive

Bethesda, MD 20814-2814

OAK RIDGE NATIONAL LABORATORY

Oak Ridge, Tennessee 37831-6283

Managed by UT-BATTELLE, LLC

for the U.S. DEPARTMENT OF ENERGY

under contract DE-AC05-00OR22725 



\begin{abstract}
This report provides methods to interpret and apply occupational uranium monitoring data. The methods are based on current international radiation protection guidance, current information on the chemical toxicity of uranium, and best available biokinetic models for uranium. Emphasis is on air monitoring data and three types of bioassay data: the concentration of uranium in urine; the concentration of uranium in feces; and the externally measured content of uranium in the chest. Primary Reference guidance levels for prevention of chemical effects and limitation of radiation effects are selected based on a review of current scientific data and regulatory principles for setting standards. Generic investigation levels and immediate action levels are then defined in terms of these primary guidance levels. The generic investigation and immediate actions levels are stated in terms of radiation dose and concentration of uranium in the kidneys. These are not directly measurable quantities, but models can be used to relate the generic levels to the concentration of uranium in air, urine, or feces, or the total uranium activity in the chest. Default investigation and immediate action levels for uranium in air, urine, feces, and chest are recommended for situations in which there is little information on the form of uranium taken into the body. Methods are prescribed also for deriving case-specific investigation and immediate action levels for uranium in air, urine, feces, and chest when there is sufficient information on the form of uranium to narrow the range of predictions of accumulation of uranium in the main target organs for uranium: kidneys for chemical effects and lungs for radiological effects. In addition, methods for using the information herein for alternative guidance levels, different from the ones selected for this report, are described.
\end{abstract}





\section{FOREWORD}

This report provides a detailed description of uranium biokinetics and bioassays applicable to evaluation of health risks from potential intakes in an occupational setting. The report addresses both the radiotoxicity and chemical (renal) toxicity of uranium. For reference occupational exposure scenarios, predictions of the time-dependent concentration of uranium in tissues and bioassay are based on biokinetic models currently recommended by the International Commission on Radiological Protection (ICRP). The ICRP's models and default assumptions for uranium were based primarily on data for human subjects exposed to uranium in controlled studies or in occupational or environmental settings. In addition, the ICRP considered an extensive database for uranium in laboratory animals. Sensitivity studies examine the robustness of these models and assumptions to ensure that radiation doses and accumulation of uranium in the kidneys are not underestimated. For example, analyses indicate that a default $5 \mu \mathrm{m}$ activity median aerodynamic diameter particle size can lead to an underestimation of radiation dose as well as the concentration of uranium in the kidneys if inhaled particles are very small. Graphs and tables illustrate interchanges of action levels depending on whether radiotoxicity or chemical toxicity is the limiting consideration for a given form and isotopic composition of uranium.

Different chemical and physical forms of uranium require different bioassay methods for the most reliable results. These methods include urine and fecal analyses and in vivo analysis. An appendix critically examines the feasibility of using hair or nails as a bioassay for uranium. Other appendices address bioassay programs, other radionuclides frequently encountered at uranium facilities, and the current regulatory status of occupational standards for uranium among U.S. Federal agencies.

This report is an up-to-date, technical resource on uranium biokinetics and bioassays. It is expected to be a useful reference or text for training and the classroom. 



\section{TABLE OF CONTENTS}

$\underline{\text { Page }}$

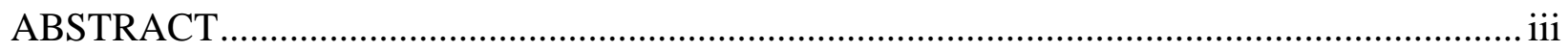

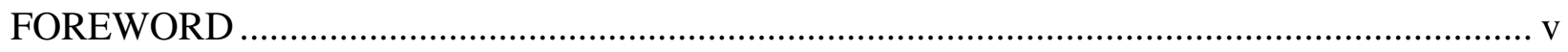

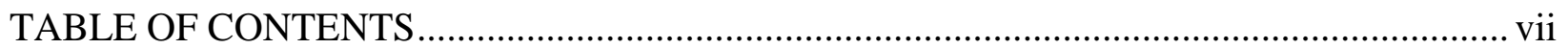

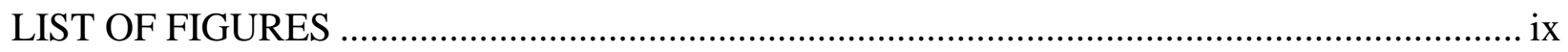

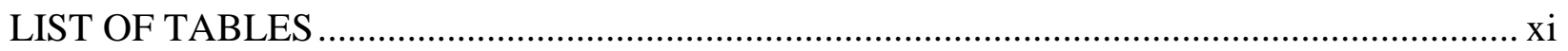

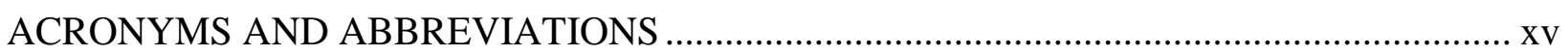

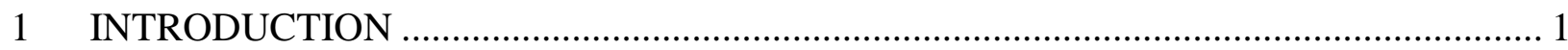

2 Reference PRIMARY GUIDANCE LEVELS ………................................................ 9

2.1 Reference Primary Guidance for Uranium as a Chemical Hazard .............................. 9

2.2 Reference Primary Guidance for Uranium as a Radiation Hazard ............................ 12

3 BIOKINETIC MODELS USED TO DERIVE SECONDARY REFERENCE GUIDANCE

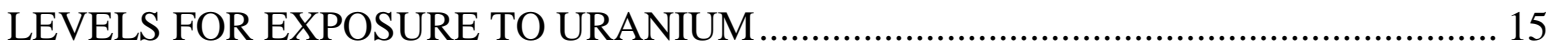

3.1 Respiratory Kinetics.................................................................................... 15

3.1.1 General Features of the ICRP's Human Respiratory Tract Model ................. 15

3.1.2 Application of the HRTM to Various Forms of Uranium .............................. 19

3.1.3 Typical Sizes of Airborne Particles in Work Environments........................... 24

3.1.4 Sensitivity of Derived Secondary Reference Guidance Levels to AMAD ..... 26

3.1.5 Comparison of AMAD and MMAD ...................................................... 29

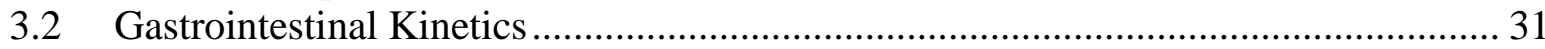

3.2.1 ICRP Models of Gastrointestinal Transit................................................... 31

3.2.2 Pub30 Model of the GI Tract ....................................................................... 31

3.2.3 ICRP's Updated Human Alimentary Tract Model .......................................... 32

3.2.4 Gastrointestinal Absorption of Uranium....................................................... 33

3.3 Biokinetics of Uranium that Reaches Blood........................................................ 34

3.4 Model Predictions of Retention and Excretion of Uranium Following Acute

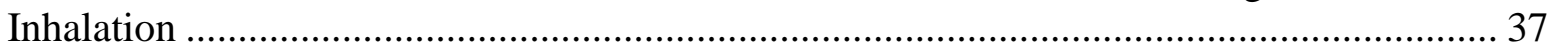

3.5 Estimates of Effective Dose Per Unit Intake of Natural Uranium Isotopes ................ 51

4 VARIATION WITH TIME IN URINARY URANIUM: A COMPLICATING FACTOR IN INTERPRETATION OF URINE MEASUREMENTS....................................................... 53

5 DERIVATION OF INVESTIGATION AND IMMEDIATE ACTION LEVELS ............... 61

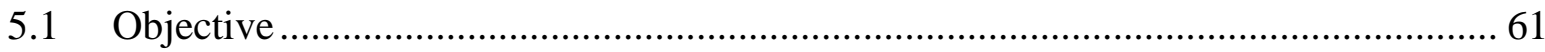

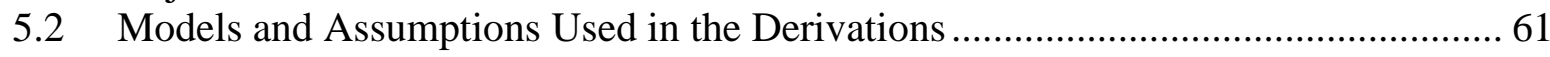

5.3 Action Levels Based on Air Monitoring ................................................................... 62

5.3.1 Action Levels for the Concentration of Airborne Uranium if the Form of

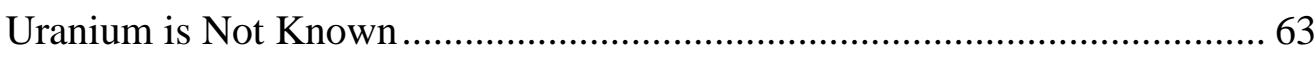

5.3.2 Action Levels for the Concentration of Uranium in Air for Reasonably Well Characterized Forms of Uranium............................................................... 66

5.4 Action Levels Based on Urinary Uranium.................................................................. 74 
5.4.1 Action Levels for Urinary Uranium for Inhalation of an Unknown Form of

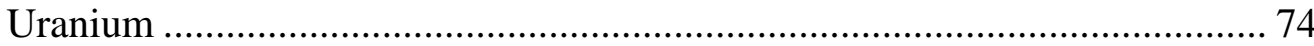

5.4.2 Action Levels for Urinary Uranium for Inhalation of a Reasonably Well Characterized Form of Uranium .................................................................. 77

5.4.3 Action Levels for Urinary Uranium for Intake through a Wound ................... 78

5.5 Action Levels Based on Measurement of Uranium in Feces....................................... 81

5.6 Action Levels Based on External Measurement of Uranium in the Chest ................. 82

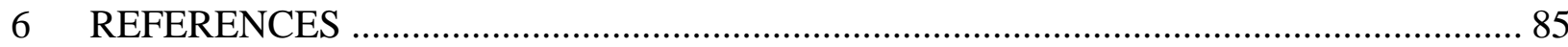

APPENDIX A: BASIC COMPONENTS OF A URANIUM BIOASSAY PROGRAM …............ 1

A.1 . Common Methods of Monitoring for Uranium ……............................................ 1

A.2 . Frequency and Normalization of Bioassay Measurements.......................................... 2

A.3 . Overview of Analytical Methods for Uranium Bioassay ……................................... 3

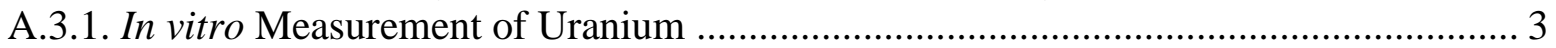

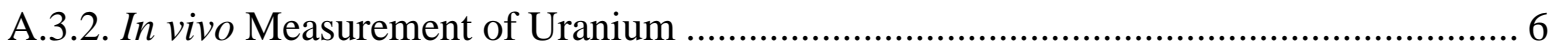

A.4 . Examples of Ongoing Uranium Bioassay Programs …………………………........ 7

A.4.1. Oak Ridge National Laboratory ………………..................................................... 7

A.4.2. U.S. Army Center for Health Promotion and Preventive Medicine ............................ 9

APPENDIX B: FEASIBILITY OF USING HAIR AND NAILS AS BIOASSAY MEDIA FOR

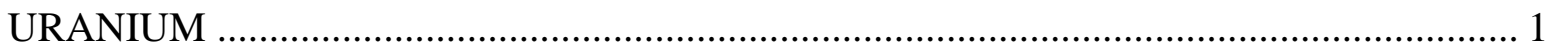

B.1 . Studies of Uranium Levels in Hair and Nails ........................................................ 1

B.2 . The Problem of Distinguishing Between Internal and External Sources .................... 2

B.3 . Example of a Toxin for Which Hair is a Workable Bioassay Medium ....................... 3

APPENDIX C: OTHER RADIONUCLIDES FREQUENTLY ENCOUNTERED AT

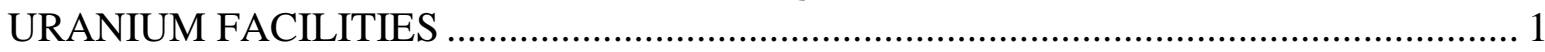

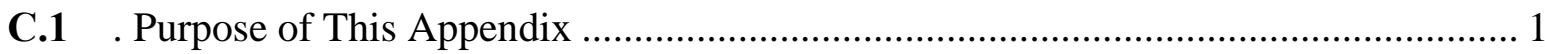

C.2 . Examples................................................................................................ 1

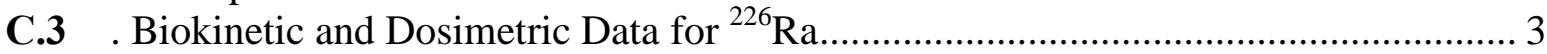

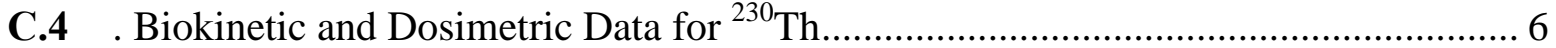

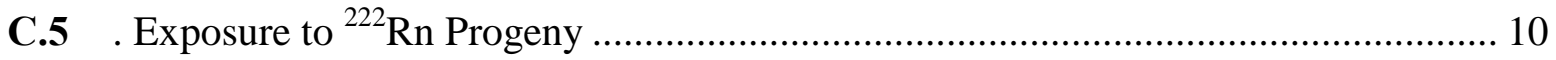

APPENDIX D: COMPARISON OF REFERENCE GUIDANCE IN THIS REPORT WITH U.S.

Federal Agency Guidance and Regulations ........................................................................ 1

D.1. U.S. Nuclear Regulatory Commission Regulatory Guides and Regulation..................... 1

D.1.1. Regulatory Guide 8.11: Applications of Bioassay for Uranium ................................. 1

D.1.2 Regulatory Guide 8.22: Bioassay at Uranium Mills ............................................. 2

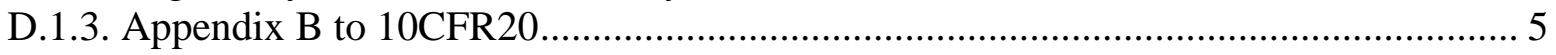

D.2. U.S. Department of Energy Regulation and Technical Standard................................. 11

D.2.1. 10 CFR 851.23 "Safety and Health Standards." ..................................................... 11

D.3. U.S. Department of Labor, Occupational Safety and Health Administration (OSHA), 11

D.4. American Conference of Governmental Industrial Hygienists (ACGIH) Threshold Limit Values (TLVs) for chemical substances and physical agents and Biological Exposure

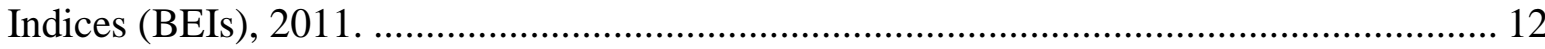




\section{LIST OF FIGURES}

$\underline{\text { Page }}$

Figure 3.1 Structure of the ICRP's respiratory tract model ................................................. 15

Figure 3.2 Model within the HRTM describing time-dependent absorption to blood............... 17

Figure 3.3 Simplification of the model of time-dependent absorption to blood by removal of the compartment "Bound material"..................................................................... 17

Figure 3.4 Model of time-dependent absorption within the HRTM generally applied when the dissolution rate of the material decreases with time..

Figure 3.5 For inhaled ${ }^{234} \mathrm{U}$, sensitivity of effective dose coefficient (E) and peak kidney concentration (P-acute and P-chronic for acute and chronic intake, respectively) to particle size

Figure 3.6 Structure of the gastrointestinal tract model used by the ICRP since the late 1970s. 31

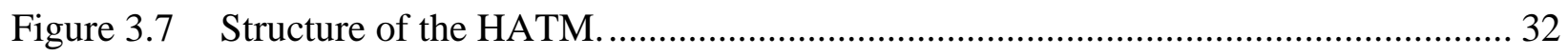

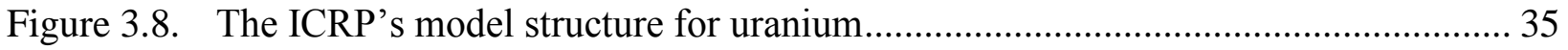

Figure 3.9 Model predictions of the time-dependent concentration of uranium in the kidneys, assuming either acute input of $1 \mu \mathrm{g}$ to blood at time zero or continuous input to blood at the rate $1 \mu \mathrm{g} / \mathrm{d}$.

Figure 3.10 Model predictions of the concentration of uranium in the kidneys as a function of time after acute inhalation of $1 \mu \mathrm{g}$ of uranium of Type F, Type M, or Type $\mathrm{S}(5 \mu \mathrm{m}$ AMAD).

Figure 3.11 Model predictions of the concentration of uranium in the kidneys as a function of time after start of continuous inhalation of uranium of Type F, Type M, or Type $\mathrm{S}(5 \mu \mathrm{m}$ AMAD) at the rate $1 \mu \mathrm{g} / \mathrm{d}$.

Figure 3.12 Model predictions of the concentration ratio of uranium in kidneys $(\mu \mathrm{g} / \mathrm{g})$ to uranium in urine $(\mu \mathrm{g} / \mathrm{mL})$ as a function of time after acute inhalation of uranium (particle size $5 \mu \mathrm{m}$ AMAD).

Figure 3.13 Model predictions of the concentration ratio of uranium in kidneys $(\mu \mathrm{g} / \mathrm{g})$ to uranium in urine $(\mu \mathrm{g} / \mathrm{mL})$ as a function of duration of continuous inhalation of uranium at a constant rate

Figure 4.1 For the hypothetical case described in Example 4.1, model predictions of the urinary excretion rate (rate of entry of uranium into the urinary bladder contents) during Week 4. 


\section{LIST OF FIGURES (continued)}

Page

Figure 4.2 For inhalation of a relatively soluble form of uranium (Type F, $5 \mu \mathrm{m}$

$\mathrm{AMAD}$; intake $=1 \mathrm{mg} / \mathrm{wk}$ ), projected urinary excretion rate and concentration of uranium in kidneys for different patterns of exposure: continuous intake at a constant rate or inhalation at a constant rate during regular work hours. 56

Figure 4.3 For inhalation of a moderately soluble form of uranium (Type M, $5 \mu \mathrm{m}$

$\mathrm{AMAD}$; intake $=1 \mathrm{mg} / \mathrm{wk}$ ), projected urinary excretion rate and concentration of uranium in kidneys for different patterns of exposure: continuous intake at a constant rate or inhalation at a constant rate during regular work hours 57

Figure 4.4 For inhalation of a relatively insoluble form of uranium (Type S, $5 \mu \mathrm{m}$ $\mathrm{AMAD}$; intake $=1 \mathrm{mg} / \mathrm{wk}$ ), projected urinary excretion rate and concentration of uranium in kidneys for different patterns of exposure: continuous intake at a constant rate or inhalation at a constant rate during regular work hours 58

Figure 4.5 For inhalation of a relatively soluble (Type F, top panel) or moderately soluble (Type $\mathrm{M}$ ) form of uranium ( $5 \mu \mathrm{m}$ AMAD, intake $=1 \mathrm{mg} / \mathrm{wk})$, projected urinary excretion rate for different patterns of exposure: continuous intake at a constant rate or inhalation at a constant rate during regular work hours.

Figure 4.6 Sequential measurements of urinary uranium in a worker acutely exposed to uranium as an oxide.

Figure 5.1 Graphs used to determine investigation levels for the concentration of uranium in air. The cases considered are depleted, natural, or ${ }^{235} \mathrm{U}$-enriched uranium of Type F, M, or S (5 $\mu$ m AMAD)......

Figure 5.2 Graphs used to determine immediate action levels for the concentration of uranium in air.

Figure 5.3 Pattern of change with time in urinary uranium for the hypothetical worker in Example 5.4 ....

Figure 5.4 Urinary data for the hypothetical case described in Example 5.5....................... 80

Figure C.1 Structure of the systemic biokinetic model for thorium ...................................... 7

Figure D.1 For an unknown form of uranium, guidance values given in this report for the average concentration of uranium for different exposure periods 


\section{LIST OF TABLES}

$\underline{\text { Page }}$

Table 1.1 Generic criteria for investigation levels and immediate action levels .................... 4

Table 1.2 Summary of investigation and immediate action levels for inhalation exposure to an unknown form of uranium........................................................... 6

Table 3.1 Default absorption types for different forms of airborne uranium ....................... 20

Table 3.2 Default and material-specific parameter values of the model shown in Figure 3.4, representing time-dependent dissolution rates of uranium

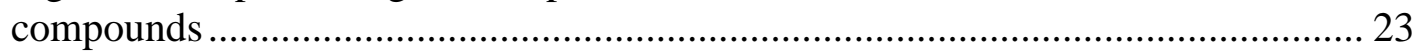

Table 3.3 Sizes of uranium aerosols in work environments ............................................. 25

Table 3.4 Transfer coefficients in ICRP's model for systemic uranium .............................. 36

Table 3.5 Model predictions of retention and excretion (fraction of intake) of uranium following acute input of uranium into blood .................................................... 38

Table 3.6 Model predictions of retention and excretion (multiple of daily intake) of uranium during continuous input of uranium into blood at a constant rate.

Table 3.7 Model predictions of retention and excretion of uranium (fraction of intake) following acute inhalation of a relatively soluble form (Type F, $5 \mu \mathrm{m}$ AMAD).

Table 3.8 Model predictions of retention and excretion of uranium (fraction of intake) following acute inhalation of a moderately soluble form (Type M, $5 \mu \mathrm{m}$ AMAD).

Table 3.9 Model predictions of retention and excretion of uranium (fraction of intake) following acute inhalation of a relatively insoluble form (Type $S$, $5 \mu \mathrm{m}$ AMAD)

Table 3.10 Model predictions of retention and excretion of uranium (multiple of daily intake) as a function of time after start of continuous inhalation of a relatively soluble form (Type F, $5 \mu \mathrm{m}$ AMAD)

Table 3.11 Model predictions of retention and excretion of uranium (multiple of daily intake) as a function of time after start of continuous inhalation of a moderately soluble form (Type M, $5 \mu \mathrm{m}$ AMAD)

Table 3.12 Model predictions of retention and excretion of uranium (multiple of daily intake) as a function of time after start of continuous inhalation of a relatively insoluble form (Type $\mathrm{S}, 5 \mu \mathrm{m}$ AMAD) .

Table 3.13 Model predictions of kidney to urine concentration ratio as a function of time following acute inhalation of uranium by a worker (particle size $=$ $5 \mu \mathrm{m}$ AMAD) 


\section{LIST OF TABLES (continued)}

$\underline{\text { Page }}$

Table 3.14 Model predictions of kidney to urine concentration ratio as a function of time after the start of continuous intake of uranium at a constant rate by inhalation, ingestion, or direct input into blood ............................................. 50

Table 3.15 Effective dose coefficients for intravenously injected $U$ isotopes........................ 52

Table 3.16 Effective dose coefficients for inhalation of uranium isotopes of Type F,

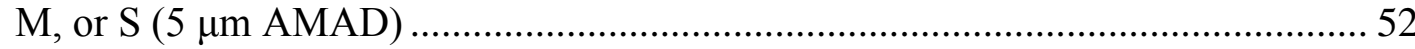

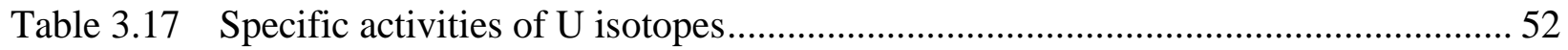

Table 4.1 Model predictions of total uranium intake based on urinary uranium measurement after weekend and alternate assumed patterns of exposure.............. 55

Table 5.1 Investigation and immediate action levels of uranium in air for application to cases in which the form of uranium is not known. 66

Table 5.2 Investigation levels for the concentration of depleted, natural, or

${ }^{235} \mathrm{U}$-enriched uranium in air for different levels of solubility of uranium, based on the default particle size $5 \mu \mathrm{m}$ AMAD.

Table 5.3 Immediate action levels for the concentration of depleted, natural, or ${ }^{235} \mathrm{U}$-enriched uranium in air for different levels of solubility (different absorption types) of uranium, based on the default particle size $5 \mu \mathrm{m}$ AMAD 73

Table 5.4 Investigation and immediate action levels for urine for application to cases in which the form of airborne uranium is not known

Table 5.5 Investigation and immediate action levels for feces for cases in which chronic inhalation of a relatively insoluble form of uranium is known or suspected

Table 5.6 Investigation and immediate action levels for uranium in the chest based

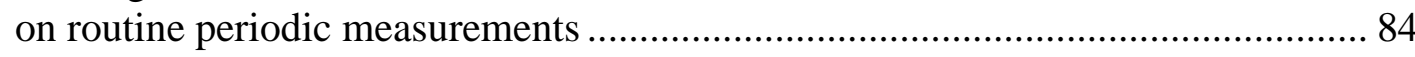

Table A.1 Uranium detection levels for different analytical methods ...................................4

Table A.2 Instrument analysis techniques used for uranium in biological samples ................. 5

Table A.3 Limits of detection of variations of the ICP-MS method of measuring

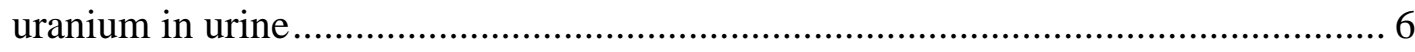

Table A.4 ORNL administrative control action levels for an accidental exposure ................. 8

Table C. $1 \quad$ The ${ }^{238} \mathrm{U}$ chain and decay data ......................................................................... 2

Table C. $2 \quad$ The ${ }^{235} \mathrm{U}$ chain and decay data ........................................................................ 2 


\section{LIST OF TABLES (continued)}

$\underline{\text { Page }}$

Table C.3 Transfer coefficients in the biokinetic model for systemic radium ......................... 4

Table C.4 Model predictions of retention and excretion of ${ }^{226} \mathrm{Ra}$ (fraction of intake) following acute inhalation of a relatively soluble form (Type F, $5 \mu \mathrm{m}$ AMAD) ...... 5

Table C.5 Model predictions of retention and excretion of ${ }^{226} \mathrm{Ra}$ (fraction of intake) following acute inhalation of a moderately soluble form (Type M, $5 \mu \mathrm{m}$ AMAD)

Table C.6 Effective dose coefficients for inhaled ${ }^{226} \mathrm{Ra}(5 \mu \mathrm{m}$ AMAD) ..................................... 6

Table C.7 Transfer coefficients in the biokinetic model for systemic thorium ........................... 8

Table C.8 Model predictions of retention and excretion of ${ }^{230} \mathrm{Th}$ (fraction of intake) following acute inhalation of a moderately soluble form (Type M, $5 \mu \mathrm{m}$ AMAD)

Table C.9 Model predictions of retention and excretion of ${ }^{230} \mathrm{Th}$ (fraction of intake) following acute inhalation of a moderately soluble form (Type $S, 5 \mu \mathrm{m}$ AMAD)

Table C.10 Effective dose coefficients for inhaled ${ }^{230}$ Th $(5 \mu \mathrm{m}$ AMAD) ................................... 10

Table D.1 Comparison of guidance in this report with Regulatory Guide 8.22 ……................. 4

Table D.2 Tissue weighting factors given in ICRP Publications 26 (1977), 60 (1991), and 103 (2008).....

Table D.3 Comparison of action levels for ${ }^{234} \mathrm{U},{ }^{235} \mathrm{U}$, and ${ }^{238} \mathrm{U}$ in air derived in this report with DACs from Appendix B of 10CFR20

Table D.4 Comparison of committed effective dose coefficients $\mathrm{E}_{26}, \mathrm{E}_{60}$, and $\mathrm{E}_{103}$ for inhaled ${ }^{234} \mathrm{U},{ }^{235} \mathrm{U}$, or ${ }^{238} \mathrm{U}$ (5 $\mu$ m AMAD) based on tissue weighting factors from ICRP Publications 26, 60, and 103, respectively...... 10 



\section{ACRONYMS AND ABBREVIATIONS}

ACGIH

AI

ALARA

ALI

AMAD

ASTM

ATSDR

$\mathrm{BB}$

$\mathrm{bb}$

$\mathrm{Bq}$

$\mathrm{C}$

$\mathrm{CDC}$

CEDE

CFR

$\mathrm{Ci}$

d

DAC

DOE or USDOE

DU

E

EPA or USEPA

ET

Exch

$\mathrm{g}$

GI

GSD

Gy

$\mathrm{h}$

HATM

HP

HR-ICP-MS

HRTM

ICP-MS

ICRP

ISL

$\mathrm{J}$

$\mathrm{keV}$

$\mathrm{L}$

LLI

$\mathrm{LN}$

$\mathrm{m}$

MC-ICP-MS

$\mu \mathrm{Ci}$

MDA
American Conference of Governmental Industrial Hygienists

Alveolar interstitium

As Low as Reasonably Achievable

Annual Limit on Intake

Activity median aerodynamic diameter

American Society for Testing and Materials

Agency for Toxic Substances and Disease Registry

Bronchi

Bronchioles

Becquerel

Centigrade

Centers for Disease Control

Committed effective dose equivalent

Code of Federal Regulations

Curie

Day

Derived Air Concentration

United States Department of Energy

Depleted uranium

Effective dose

United States Environmental Protection Agency

Extrathoracic

Exchangeable (with blood plasma)

Gram

Gastrointestinal

Geometric standard deviation

Gray

Hour

Human Alimentary Tract Model

Health physicist

High Resolution Inductively Coupled Plasma Mass Spectrometry

Human Respiratory Tract Model

Inductively Coupled Plasma Mass Spectrometry

International Commission on Radiological Protection

In situ leaching

Joule

Thousand electron volts

Liter

Lower large intestine

Lymph nodes

Meter

Multi-Collector Inductively Coupled Plasma Mass Spectrometry

Microcurie

Minimum detectable activity 


\section{ACRONYMS AND ABBREVIATIONS (continued)}

$\begin{array}{ll}\text { MeV } & \text { Million electron volts } \\ \mathrm{mg} & \text { Milligram } \\ \mu \mathrm{g} & \text { Microgram } \\ \mathrm{mL} & \text { Milliliter } \\ \mu \mathrm{m} & \text { Micrometer } \\ \text { MMAD } & \text { Mass median aerodynamic diameter } \\ \text { mo } & \text { Month } \\ \text { MOX } & \text { Mixed oxide fuel } \\ \text { MPDc } & \text { Maximum Permissible Dose Commitment } \\ \text { NCRP } & \text { National Council on Radiation Protection and Measurements } \\ \text { ng } & \text { Nanogram } \\ \text { nm } & \text { Nanometer } \\ \text { Nonexch } & \text { Nonexchangeable (with blood plasma) } \\ \text { NRC or USNRC } & \text { United States Nuclear Regulatory Commission } \\ \text { NUREG } & \text { US Nuclear Regulatory Commission Regulation } \\ \text { ORNL } & \text { Oak Ridge National Laboratory } \\ \text { OSHA } & \text { Occupational Safety and Health Administration } \\ \text { Pub30 } & \text { Publication 30 of the International Commission on Radiological Protection } \\ \text { Q-ICP-MS } & \text { Quadrupole Inductively Coupled Plasma Mass Spectrometry } \\ \text { RBC } & \text { Red blood cells } \\ \text { RG } & \text { Regulatory Guide } \\ \text { SD } & \text { Standard deviation } \\ \text { SEQ } & \text { Sequestered (in respiratory tissue) } \\ \text { SF-ICP-MS } & \text { Sector Field Inductively Coupled Plasma Mass Spectrometry } \\ \text { SI } & \text { Small intestine } \\ \sigma_{g} & \text { Geometric standard deviation } \\ \text { SpA } & \text { Specific activity } \\ \text { St } & \text { Stomach } \\ \text { ST0 } & \text { Soft tissues with rapid turnover rate } \\ \text { ST1 } & \text { Soft tissues with intermediate turnover rate } \\ \text { ST2 } & \text { Soft tissues with slow turnover rate } \\ \text { Sv } & \text { Sievert } \\ \text { TH } & \text { Thoracic } \\ \text { U } & \text { Uranium } \\ \text { ULI } & \text { Upper large intestine } \\ \text { UNSCEAR } & \text { United Nations Scientific Committee on the Effects of Atomic Radiation } \\ \text { USACHPPM } & \text { U.S. Army Center for Health Promotion and Preventive Medicine } \\ \text { UV } & \text { Ultraviolet } \\ \text { WHO } & \text { World Health Organization } \\ \text { wk } & \text { Week } \\ \text { WL } & \text { Working Level } \\ \text { WLM } & \text { Working Level Month } \\ \text { wT } & \text { Tissue weighting factor } \\ \text { y } & \text { Year } \\ \end{array}$




\section{INTRODUCTION}

Health risks associated with elevated intake of uranium may be divided into two categories: chemical toxicity to tissues, primarily the kidneys; and radiogenic injury to lungs, bone, and other tissues that may result in an increased risk of cancer of these tissues.

The relative significance of the chemical and radiation hazards from intake of the natural uranium isotopes ${ }^{234} \mathrm{U},{ }^{235} \mathrm{U}$, and ${ }^{238} \mathrm{U}$ depends on their isotopic mixture and the chemical and physical form of uranium taken into the body. Chemical toxicity generally has been considered the overriding hazard for intake of relatively soluble uranium compounds with naturally occurring isotopic mixtures, based on studies on laboratory animals (Wrenn, et al. 1985). This would also apply to intake of relatively soluble forms of depleted uranium, which has an even lower specific activity (radioactive decays per second per gram of material) than natural uranium. The radiogenic risk increases with the level of ${ }^{235} \mathrm{U}$-enrichment due mainly to an associated increase in the percentage of ${ }^{234} \mathrm{U}$, which has a higher specific activity than ${ }^{235} \mathrm{U}$ or ${ }^{238} \mathrm{U}$. For inhalation of relatively insoluble uranium compounds, the radiation dose to the lungs could become the prevailing consideration even for natural or depleted uranium due to an increased residence time in the lungs and low fractional absorption of deposited uranium to blood.

The purpose of this report is to provide methods for interpreting uranium monitoring data and limiting exposure to uranium in the workplace. Although various types of monitoring data and different exposure pathways are considered, emphasis is on interpretation of air monitoring data and three main types of bioassay data: the concentration of uranium in urine, the concentration of uranium in feces, and the externally measured content of uranium in the chest. Recommendations concerning limiting values for these quantities are based on current radiation protection guidance, current information on chemical toxicity of uranium, and the best available biokinetic models for uranium. A recommended limiting value is based on the more restrictive of two derived values, one determined from primary guidance for uranium as a chemical hazard and the other from primary guidance for uranium as a radiation hazard.

The primary guidance for prevention of chemical toxicity is intended to ensure that the concentration of uranium in the kidneys in workers remains well below levels projected to result in nephrotoxicity, as judged from data on human subjects and laboratory animals. The primary guidance for limitation of radiation effects is consistent with guidance in Publications 60 and 103 of the International Commission on Radiological Protection (ICRP 1991, 2008).

- Primary guidance for prevention of chemical toxicity: The concentration of uranium in the kidneys should not exceed $1.0 \mu \mathrm{g} \mathrm{U} / \mathrm{g}$ kidney at any time.

- Primary guidance for limitation of radiation effects: The committed effective dose from intake of uranium during any 1-y period (the "annual effective dose") should not exceed $0.02 \mathrm{~Sv}$ as an average over any 5-y period and should not exceed $0.05 \mathrm{~Sv}$ in any single year. The value $0.02 \mathrm{~Sv}$ should be used for planning purposes for any 1-y period.

Background information on these primary guidance levels is given in Section 2. 
The primary guidance levels given above are not directly measurable quantities but provide a basis for derivation of secondary guidance levels that are measurable (e.g., the concentration of uranium in air or urine). Derivation of secondary guidance levels requires the application of biokinetic and dosimetric models for internally deposited uranium. The dosimetry system applied in this report is based on ICRP Publication 60 (1991) and Publication 68 (1994b) except that an updated model of transit of material through the alimentary tract is applied.

The biokinetic models used in this report are summarized in Section 3 and include:

- the ICRP's Human Respiratory Tract Model (HRTM) adopted in ICRP Publication 66 (1994a);

- the ICRP's Human Alimentary Tract Model (HATM) adopted in ICRP Publication 100 (2006), together with gastrointestinal absorption fractions applied in ICRP Publication 68 (1994b) for relatively soluble and relatively insoluble forms of uranium;

- $\quad$ the biokinetic model for systemic uranium in adults, adopted in ICRP Publication 69 (1995a).

Derivations of secondary guidance levels for exposure to uranium are based on characteristics of a reference adult male as defined in ICRP Publication 89 (2002). Analyses done for this report indicate that derived guidance values would differ little if characteristics of a reference adult female were applied instead (Section 5).

Three default levels of solubility or "absorption types" of inhaled uranium are considered:

- Relatively soluble aerosols. These are represented by Type F material as defined in ICRP Publication 66 (1994a). The assumed particle size is $5 \mu \mathrm{m}$ AMAD (activity median aerodynamic diameter), which is the ICRP's default particle size for consideration of occupational intakes. Parameter values for Type F depict fast dissolution in the respiratory tract and a high level of absorption from the respiratory tract to blood. For uranium of Type F, a gastrointestinal absorption fraction of 0.02 is applied to activity that is swallowed after escalation from the respiratory tract.

- Moderately soluble aerosols. These are represented by Type M material (5 $\mu \mathrm{m}$ AMAD) as defined in ICRP Publication 66 (1994a). Parameter values for Type M depict a moderate rate of dissolution and an intermediate level of absorption to blood. For uranium of Type M, a gastrointestinal absorption fraction of 0.02 is applied as a cautiously high value to activity that is swallowed after escalation from the respiratory tract.

- Relatively insoluble aerosols. These are represented by Type S (5 $\mu \mathrm{m}$ AMAD) material as defined in ICRP Publication 66 (1994a). Respiratory parameter values for Type S depict a low rate of dissolution and a low level of absorption to blood. For uranium of Type $\mathrm{S}$, a gastrointestinal absorption fraction of 0.002 is applied to activity that is swallowed after escalation from the respiratory tract.

Guidance is given in Section 3 regarding association of specific chemical forms of uranium with specific default absorption types (Type F, Type M, or Type S), or assignment of materialspecific parameter values.

Because the frequency and duration of exposure to uranium vary from one facility to another and from one worker to another in the same facility, it is not feasible to derive secondary guidance 
values for a comprehensive set of potential exposure patterns. The secondary guidance values given in this report are based on consideration of two idealized patterns of exposure: acute exposure, or continuous exposure at a constant rate. The case of continuous exposure is used as a surrogate for chronic occupational exposure. Section 3 provides tables and figures of ICRP model predictions of retention and excretion of uranium based on these two idealized exposure patterns, various forms of uranium taken into the body, and different pathways of entry into the body. Section 3 also includes an analysis of the sensitivity of derived secondary guidance to the assumed particle size.

Section 4 compares model predictions of retention and excretion of uranium based on the assumption of continuous intake with predictions for intermittent exposure patterns that could occur in the workplace. Section 4 also discusses the problem of interpreting routine urinary uranium measurements in view of the rapid fluctuations of urinary uranium that can occur in uranium workers due to relatively fast urinary clearance of a substantial portion of absorbed uranium. For example, the concentration of uranium in a urine sample collected during or shortly after work hours may be dominated by intake occurring earlier in the day and may be a misleading indicator of total exposure that has occurred since the previous urine measurement. Sampling schemes are proposed for determining reasonable estimates of the average rate of urinary excretion of uranium in chronically exposed workers.

The background material provided in Sections 2-4 is applied in Section 5 to derive secondary guidance levels for exposure to different forms of uranium in the workplace. These secondary guidance levels are referred to as investigation levels and immediate action levels and are given in terms of the mass concentration or activity concentration of uranium in air, urine, or feces, or the total uranium activity in the chest. Essentially, an investigation level indicates the need to confirm the validity of measurements and adequacy of confinement controls and determine whether work limitations are appropriate. An immediate action level indicates that a number of safeguards should be put into place immediately, including removal of workers from further exposure until exposure conditions are found to be acceptable.

Table 1.1 lists "generic" investigation and immediate action levels and the actions that should be taken at each level. These levels are generic in the sense that they are defined in terms of the primary guidance levels given earlier rather than in terms of specific measurable quantities. 
Table 1.1 Generic criteria for investigation levels and immediate action levels

\begin{tabular}{|c|c|c|}
\hline Type of information & Interpretation & Actions \\
\hline $\begin{array}{l}\text { Monitoring data indicate both of the } \\
\text { following: } \\
\text { (a) The kidney concentration does not } \\
\text { exceed } 0.3 \mu \mathrm{g} \mathrm{U} / \mathrm{g} \text { kidney and is not } \\
\text { projected on the basis of models to } \\
\text { exceed this value at current levels of } \\
\text { exposure. } \\
\text { (b) The annual effective dose has not } \\
\text { exceeded } 0.02 \mathrm{~Sv} \text { over the past year } \\
\text { and is not projected to exceed this } \\
\text { value at current levels of exposure. }\end{array}$ & $\begin{array}{l}\text { U confinement } \\
\text { indicated to be } \\
\text { adequate. }\end{array}$ & No corrective actions needed. \\
\hline $\begin{array}{l}\text { Monitoring data indicate one or both of the } \\
\text { following: } \\
\text { (a) The kidney concentration has exceeded } \\
\text { or will eventually exceed } 0.3 \mu \mathrm{g} \mathrm{U} / \mathrm{g} \\
\text { kidney at current levels of exposure. } \\
\text { (b) The annual effective dose has exceeded } \\
\text { or will eventually exceed } 0.02 \mathrm{~Sv} \text { at } \\
\text { current levels of exposure. }\end{array}$ & $\begin{array}{l}\text { Investigation } \\
\text { level. Uranium } \\
\text { confinement or } \\
\text { respiratory } \\
\text { controls may not } \\
\text { provide } \\
\text { adequate margin } \\
\text { of safety. }\end{array}$ & $\begin{array}{l}\text { 1. Confirm results underlying the model } \\
\text { prediction (e.g., repeat latest urinalysis } \\
\text { and increase frequency of urine } \\
\text { sampling). } \\
\text { 2. Reassess model predictions. Where } \\
\text { feasible, apply worker-specific exposure } \\
\text { scenarios in place of the idealized } \\
\text { scenarios underlying the derived } \\
\text { investigation levels. } \\
\text { 3. Identify cause of elevated monitoring } \\
\text { data and initiate additional control } \\
\text { measures if initial results are confirmed. } \\
\text { 4. If monitoring data are found to be } \\
\text { anomalous, investigate sampling and } \\
\text { measurement procedures and correct if } \\
\text { necessary. } \\
\text { 5. If elevated exposure to a worker is } \\
\text { confirmed, determine whether other } \\
\text { workers may have been exposed and } \\
\text { make bioassay measurements for those } \\
\text { workers. } \\
\text { 6. Consider work assignment limitations for } \\
\text { workers with elevated intakes of } \\
\text { uranium. }\end{array}$ \\
\hline $\begin{array}{l}\text { Monitoring data indicate one or more of } \\
\text { the following: } \\
\text { (a) The kidney concentration has exceeded } \\
\text { or will eventually exceed } 1.0 \mu \mathrm{g} \mathrm{U} / \mathrm{g} \\
\text { kidney at current levels of exposure. } \\
\text { (b) The annual effective dose has exceeded } \\
\text { or will eventually exceed } 0.05 \mathrm{~Sv} \text { at } \\
\text { current levels of exposure. }\end{array}$ & $\begin{array}{l}\text { Immediate } \\
\text { action level. } \\
\text { Uranium } \\
\text { confinement, } \\
\text { respiratory } \\
\text { protection, or } \\
\text { monitoring } \\
\text { program not } \\
\text { acceptable. }\end{array}$ & $\begin{array}{l}\text { 1. Take the actions indicated above. } \\
\text { 2. Immediately remove from further } \\
\text { exposure any workers estimated to have } \\
\text { a kidney uranium concentration } \\
\text { approaching or exceeding } 1.0 \mu \mathrm{g} \mathrm{U} / \mathrm{g} \\
\text { kidney. } \\
\text { 3. Continue operations only if source of } \\
\text { elevated uranium is clearly identified and } \\
\text { corrected, or if it is clearly established } \\
\text { that the monitoring data leading to the } \\
\text { model predictions are incorrect. } \\
\text { 4. Analyze bioassay samples weekly or } \\
\text { more frequently for workers in affected } \\
\text { area. }\end{array}$ \\
\hline
\end{tabular}


Table 1.1 provides the basis for derivation of numerical investigation and immediate action levels based on the following types of measurements:

The concentration of uranium in air: Continuous air monitoring during work hours typically is the primary method for monitoring and control of airborne uranium. An air monitoring program should include not only measurement of the mass concentration and activity concentration of airborne uranium but also measurement of the solubility of aerosols in which uranium is carried. The main purpose of such measurements is to determine whether a significant portion of the airborne material is highly insoluble. This is important because inhalation of highly insoluble material may result in accumulation of uranium in the lungs and elevated radiation dose to lung tissue. Special determinations of the solubility of uranium aerosols are needed when changes in operations may affect the solubility of the material to which workers are exposed.

Urine measurements: Measurement of the rate of excretion of uranium in urine is another important component of a uranium monitoring program. Urinary excretion measurements may detect significantly high acute exposures or gradual unfavorable trends in exposure not evident from air monitoring data alone. Urine sampling generally is performed at regular intervals, with the frequency of sampling depending on the exposure potential of the individual.

In vivo thorax (chest) measurements: Periodic in vivo thorax measurements are needed in cases where there is a potential for inhalation of elevated quantities of relatively insoluble forms of uranium. Special in vivo thorax measurements are used to estimate the level of intake in the event of known or suspected short-term exposure to relatively insoluble uranium. Exposure to relatively insoluble forms of uranium may not be revealed by urinalysis due to a low rate of dissolution of the inhaled material in the lungs and absorption of uranium to blood. In vivo thorax measurements typically are performed at wider time intervals than routine urinalysis.

Fecal measurements: Fecal analysis generally is not performed routinely but can be a useful assessment tool if it is suspected that workers have been exposed to relatively insoluble uranium aerosols. Inhalation of a relatively insoluble uranium aerosol cannot be determined by urinary excretion measurements alone. A low urinary to fecal excretion ratio for uranium in a worker provides suggestive evidence that most or all of the inhaled uranium is in relatively insoluble form, although the possibility usually cannot be ruled out that fecal uranium represents largely ingested activity.

Table 1.2 summarizes investigation levels and immediate action levels derived in Section 5 for uranium in air, urine, feces, and chest. The values in Table 1.2 apply to inhalation of an unknown form of uranium. In the case of fecal or chest measurements the values apply either to an unknown form of inhaled uranium or a form known to have a relatively insoluble component. 
Table 1.2 Summary of investigation and immediate action levels for inhalation exposure to an unknown form of uranium

\begin{tabular}{|c|c|c|c|}
\hline \multirow[b]{2}{*}{ Measure } & \multirow[b]{2}{*}{ Level } & \multicolumn{2}{|c|}{ Action level $^{a, b}$} \\
\hline & & $\begin{array}{c}\text { Mass } \\
\text { concentration } \\
\text { or content of } U\end{array}$ & $\begin{array}{c}\text { Activity } \\
\text { concentration or } \\
\text { content or } \mathrm{U}^{\mathrm{c}}\end{array}$ \\
\hline $\begin{array}{l}\text { Concentration of } \\
\text { unknown form of } \\
\text { uranium in air }\end{array}$ & $\begin{array}{l}\text { Investigation level } \\
\text { Average over a } 40 \text {-h workweek } \\
\text { Average over } 2 \text { consecutive weeks } \\
\text { Average over a month } \\
\text { Average over } 3 \text { months }\end{array}$ & $\begin{array}{l}60 \mu \mathrm{g} / \mathrm{m}^{3} \\
45 \mu \mathrm{g} / \mathrm{m}^{3} \\
30 \mu \mathrm{g} / \mathrm{m}^{3} \\
15 \mu \mathrm{g} / \mathrm{m}^{3}\end{array}$ & 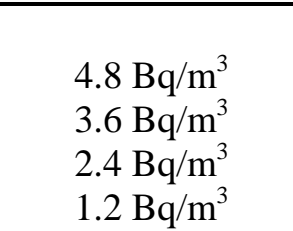 \\
\hline & $\begin{array}{l}\text { Immediate action level } \\
\text { Average over a } 40 \text {-h workweek } \\
\text { Average over } 2 \text { consecutive weeks } \\
\text { Average over a month } \\
\text { Average over } 3 \text { months }\end{array}$ & $\begin{array}{c}200 \mu \mathrm{g} / \mathrm{m}^{3} \\
150 \mu \mathrm{g} / \mathrm{m}^{3} \\
100 \mu \mathrm{g} / \mathrm{m}^{3} \\
50 \mu \mathrm{g} / \mathrm{m}^{3}\end{array}$ & $\begin{array}{l}12 \mathrm{~Bq} / \mathrm{m}^{3} \\
9.0 \mathrm{~Bq} / \mathrm{m}^{3} \\
6.0 \mathrm{~Bq} / \mathrm{m}^{3} \\
3.0 \mathrm{~Bq} / \mathrm{m}^{3}\end{array}$ \\
\hline $\begin{array}{l}\text { Concentration of } \\
\text { uranium in urine } \\
\text { after inhalation of } \\
\text { unknown form }\end{array}$ & $\begin{array}{l}\text { Investigation level } \\
\text { Immediate action level }\end{array}$ & $\begin{array}{l}10 \mu \mathrm{g} / \mathrm{L} \\
33 \mu \mathrm{g} / \mathrm{L}\end{array}$ & $\begin{array}{l}0.6 \mathrm{~Bq} / \mathrm{L} \\
1.5 \mathrm{~Bq} / \mathrm{L}\end{array}$ \\
\hline $\begin{array}{l}\text { Concentration of } \\
\text { uranium in feces }\end{array}$ & $\begin{array}{l}\text { Investigation level } \\
\text { Immediate action level }\end{array}$ & $\begin{array}{l}\text { Not specified } \\
\text { Not specified }\end{array}$ & $\begin{array}{c}0.025 \mathrm{~Bq} / \mathrm{g} \\
0.06 \mathrm{~Bq} / \mathrm{g}\end{array}$ \\
\hline $\begin{array}{l}\text { Total activity of } \\
\text { uranium in the } \\
\text { chest }\end{array}$ & $\begin{array}{l}\text { Investigation level } \\
\text { Immediate action level }\end{array}$ & $\begin{array}{l}\text { Not specified } \\
\text { Not specified }\end{array}$ & $\begin{array}{l}200 \mathrm{~Bq} \\
500 \mathrm{~Bq}\end{array}$ \\
\hline $\begin{array}{l}{ }^{a} \text { The more restricti } \\
{ }^{b} \text { Guidance levels a } \\
\text { regard to both the solul } \\
\text { and its isotopic compo: } \\
{ }^{234} \mathrm{U} \text { and which has sliq } \\
\text { As discussed in Sectior } \\
\text { reasonably well charac } \\
{ }^{c} \text { Action levels deri } \\
\text { radiation dose other th } \\
\text { levels should be reduce } \\
{ }^{d} \text { Action levels for } \mathrm{f} \\
\text { known or suspected. }\end{array}$ & $\begin{array}{l}\text { f the two values based on mass concentration } \\
\text { t for exposure to an unknown form of uraniun } \\
\text { y of airborne uranium (100\% is Type F materi } \\
\text { of ( } 100 \% \text { of measured activity is }{ }^{234} \mathrm{U} \text {, which } \\
\text { higher effective dose coefficients than }{ }^{235} \mathrm{U} \\
\text { higher action levels may be appropriate in son } \\
\text { zed. } \\
\text { from radiation protection guidelines are based } \\
\text { ternally deposited uranium are negligible. If } \\
\text { s required to conform to the primary guidance } \\
\text { excretion are applicable in cases where inhal }\end{array}$ & $\begin{array}{l}\text { activity concentratio } \\
\text { nd are based on a wor } \\
\text { implying relatively hi } \\
\text { e dominant source of } \\
{ }^{8} \mathrm{U} \text { when expressed as } \\
\text { cases in which the for } \\
\\
\text { the assumption that o } \\
\text { is not the case, the re } \\
\text { limitation of radiatio } \\
\text { on of a relatively insol }\end{array}$ & $\begin{array}{l}\text { is applied. } \\
\text {-case situation with } \\
\text { absorption to blood) } \\
\text { ctivity for enriched } \\
\text { lose per unit activity). } \\
\text { of airborne uranium is } \\
\text { cupational sources of } \\
\text { mmended action } \\
\text { effects (see text). } \\
\text { ole form of uranium is }\end{array}$ \\
\hline
\end{tabular}

Action levels derived from radiation protection guidelines (last column of Table 1.2) are based on the assumption that occupational radiation doses from sources other than internally deposited uranium are negligible, defined here as $<0.002 \mathrm{~Sv}$ ( $10 \%$ of the primary guidance level of 0.02 $\mathrm{Sv})$. If this is not the case, the radiologically based action levels should be reduced as required to ensure that the total radiation dose does not exceed the primary radiological guidance. Suppose, for example, that a worker's projected annual external dose based on a quarterly badge reading is $0.005 \mathrm{~Sv}$, and it is impractical to reduce the worker's external exposure. Then the radiologically based investigation and immediate action levels should be reduced by $25 \%(100 \% \times 0.005 \mathrm{~Sv} /$ $0.02 \mathrm{~Sv})$ and $10 \%(100 \% \times 0.005 \mathrm{~Sv} / 0.05 \mathrm{~Sv})$, respectively, where $0.02 \mathrm{~Sv}$ and $0.05 \mathrm{~Sv}$ are the 
primary guidance values underlying radiologically based investigation and immediate action levels, respectively. An action level would then be the more restrictive of the unchanged value derived from chemical guidance and the re-derived value based on radiological guidance.

Derivations of the investigation and immediate action levels given in Table 1.2 are based on worst-case assumptions regarding the form of uranium entering the body by the inhalation pathway. Since this report addresses intakes in the occupational environment, inhalation and wounds are the only intake pathways considered in the derivations. Swallowed uranium is taken into account as a secondary pathway associated with transfer of inhaled uranium from the respiratory tract to the alimentary tract. However, oral ingestion of uranium is considered to be a relatively unimportant pathway for intake of uranium in the workplace and is not addressed in this report. If there is reasonably good information on the form of inhaled uranium, higher action levels may be implied by the generic criteria in Table 1.1. Section 5 provides methods for deriving case-specific action levels for the following situations:

Concentration of a known form of uranium in air. If the airborne uranium is reasonably well characterized with regard both to solubility (as defined by any of the ICRP's default absorption types) and isotopic mixture (representing natural, ${ }^{235} \mathrm{U}$-enriched, or ${ }^{235} \mathrm{U}$-depleted uranium), the investigation and immediate action levels may be determined from graphs given in Section 5.

Concentration of uranium in urine following inhalation of a known form. When the form of inhaled uranium is reasonably well characterized, investigation and immediate action levels based on urinary uranium may be calculated from tables given in Section 3, as illustrated in Section 5.

Action levels for urinary uranium in the case of intake of uranium through a wound. It is important to monitor a worker who has been exposed to uranium through a wound to determine whether removal from further exposure or medical intervention is indicated. Section 5 illustrates how urinary excretion measurements may be used, together with tables in Section 3 (or predictions of a wound model plus systemic model) to estimate the rate of transfer of uranium from a wound to blood.

All investigation and immediate actions levels derived in Section 5 and all illustrative examples given in that section are based on application of default model parameter values recommended by the ICRP. Action levels may be derived from material-specific parameter values describing dissolution and absorption in the lungs or fractional absorption from the gastrointestinal tract, whenever there is reasonably strong information in support of such parameter values. Information that might be used to develop material-specific dissolution rates include site-specific data from in vitro dissolution studies of the material in simulated lung fluid and reported measurements on workers exposed to the same material. With regard to application of published material-specific parameter values, it should be kept in mind that the dissolution rate of some materials depends on factors that may differ from site to site such as the process of formation of the material. 
Appendix A of this report discusses basic components of a uranium bioassay program, including analytical methods commonly employed as part of in vitro and in vivo monitoring activities. The basic components of a uranium bioassay program are illustrated in the context of the bioassay program for uranium and other radionuclides at Oak Ridge National Laboratory. A brief discussion is given of a more narrowly focused bioassay program developed by the U.S. Army Center for Health Promotion and Preventive Medicine (USACHPPM) for U.S. soldiers potentially exposed in battle to depleted uranium.

Appendix B examines the practicality of using hair and nails as biomarkers in a uranium bioassay program. The main conclusion is that uranium measured in hair and nails cannot be assumed to arise wholly, or even mainly, from internally deposited uranium.

Appendix $C$ addresses radionuclides other than the natural uranium isotopes ${ }^{234} U,{ }^{235} U$, and ${ }^{238} U$ that may be found in relatively high quantities at a uranium facility. Decay data are provided for members of the ${ }^{238} U$ and ${ }^{235} \mathrm{U}$ chains, which are commonly encountered at uranium facilities. Effective dose coefficients and biokinetic model predictions needed for interpretation of bioassay are tabulated for the following potentially significant types of internal exposure at uranium facilities: acute inhalation of soluble or moderately soluble forms of ${ }^{226} \mathrm{Ra}$; acute inhalation of moderately soluble or relatively insoluble forms of ${ }^{230} \mathrm{Th}$; and chronic inhalation of short-lived ${ }^{222} \mathrm{Rn}$ progeny.

Appendix D summarizes the guidance provided in Regulatory Guide 8.11, "Applications of Bioassay for Uranium"; Regulatory Guide 8.22, "Bioassay at Uranium Mills"; and Appendix B of 10CFR20 and makes comparisons with guidance proposed in the present report. Appendix D also examines the sensitivity of committed effective dose coefficients, and hence the radiologically based action levels given in this report, to the choice among tissue weighting factors recommended in ICRP Publication 26 (1977), Publication 60 (1991), and Publication 103 (2008). In addition, Appendix D compares guidance levels in this report to DOE and OSHA regulations and to ACGIH guidance. 


\section{REFERENCE PRIMARY GUIDANCE LEVELS}

\subsection{Reference Primary Guidance for Uranium as a Chemical Hazard}

Primary guidance levels provide the basis for interpretation of monitoring data for uranium and limitation of uranium in the monitored media. The authors have selected reference primary guidance levels on the basis of a review of the scientific literature related to potential radiological and chemical effects of uranium and consideration of the role of health effects classification in setting standards by U.S. Federal agencies. A summary of the literature review and criteria for standards follows.

Toxic effects of uranium on the kidneys are assumed to occur only when the renal uranium concentration exceeds some threshold level. Since the early 1950 s a concentration of $3 \mu \mathrm{g} \mathrm{U} / \mathrm{g}$ kidney has served as a primary guidance level for avoidance of chemical toxicity in workers exposed to uranium (Voegtlin and Hodge 1953, Spoor and Hursh 1973, Stopps and Todd 1982). This level represents a committee's judgment based primarily on results of animal experiments conducted in the 1940s.

Information collected since the 1940s indicates that the traditional guidance level of $3 \mu \mathrm{g} \mathrm{U} / \mathrm{g}$ kidney is above the no-effects level but probably below a serious-effects level with regard to renal dysfunction. Subjects with intakes resulting in estimated peak concentrations near $3 \mu \mathrm{g} \mathrm{U} / \mathrm{g}$ kidney have shown transient biochemical indicators of renal dysfunction but no acute illnesses or indications of long-term adverse health effects (U.S. National Research Council 2008). On the other hand, acutely exposed persons with estimated peak concentrations substantially exceeding $6 \mu \mathrm{g} \mathrm{U} / \mathrm{g}$ kidney have shown protracted biochemical indicators of renal dysfunction and sometimes severe illness (U.S. National Research Council 2008). Kathren and Burklin (2008) concluded from a review of the literature that there have been no reported human deaths attributable to chemical toxicity of uranium.

Guilmette and coworkers (2004) reviewed information on renal toxicity of uranium as part of the Capstone health risk assessment study of military uses of depleted uranium. They concluded that:

- $\quad$ uranium concentrations $\leq 2.2 \mu \mathrm{g} \mathrm{U} / \mathrm{g}$ kidney will not result in detectable effects;

- concentrations $>2.2 \mu \mathrm{g} \mathrm{U} / \mathrm{g}$ kidney but $\leq 6.4 \mu \mathrm{g} \mathrm{U} / \mathrm{g}$ kidney may result in transient indicators of renal dysfunction without overt symptoms of illness;

- concentrations $>6.4 \mu \mathrm{g} \mathrm{U} / \mathrm{g}$ kidney but $\leq 18 \mu \mathrm{g} \mathrm{U} / \mathrm{g}$ kidney may result in protracted symptoms of renal dysfunction and possibly illness;

- concentrations $>18 \mu \mathrm{g} \mathrm{U} / \mathrm{g}$ kidney are likely to result in severe clinical symptoms of renal dysfunction.

These conclusions refer to peak concentrations following brief exposure to uranium. These authors also reviewed twenty-seven cases of human $U$ exposures reported in the scientific literature and listed transient effects in the kidney in eight cases. The peak kidney concentration for those eight cases, apparently calculated by these authors or the original investigators using selected biokinetic models, ranged from 1 to $6 \mu \mathrm{g} \mathrm{U} / \mathrm{g}$ kidney. In a ninth case, a biochemical 
indicator of renal dysfunction persisted for three weeks, and the estimated peak kidney concentration was $3 \mu \mathrm{g} \mathrm{U} / \mathrm{g}$ kidney.

By contrast to the no-effects level of $2.2 \mu \mathrm{g}$ U/g kidney proposed by those authors, a U.S. National Research Council committee recently concluded that transient adverse renal effects of uranium including proteinuria and glucosuria may occur at peak kidney concentrations as low as $1.0 \mu \mathrm{g} \mathrm{U} / \mathrm{g}$ kidney (U.S. National Research Council 2008).

In a cohort of Gulf War veterans with embedded fragments of depleted uranium (DU) metal resulting from "friendly fire" incidents, uranium concentrations in urine measured every two years since 1993 persistently range from 10 to over 500 times normal levels (Squibb et al. 2005). This indicates that the embedded DU fragments are gradually releasing uranium to blood in these subjects. The biokinetic models applied in the present report were used to estimate kidney uranium concentrations in these veterans based on their urinary uranium excretion through about 2001 (Squibb et al. 2005). Estimated kidney concentrations exceeded $0.1 \mu \mathrm{g} \mathrm{U} / \mathrm{g}$ kidney in several veterans and $\geq 0.6 \mu \mathrm{g} \mathrm{U} / \mathrm{g}$ kidney in two cases. Subtle changes in measures of renal proximal tubule function have been evident in some of the veterans, but no clinical evidence of decreased renal function has been observed in this cohort (Squibb et al. 2005).

A 16-year follow-up study of 35 members of a larger cohort of 77 of these Gulf I veterans, 11 of whom are bearing DU embedded fragments, were examined in a broad spectrum of medical and laboratory tests. The subjects with embedded fragments continue to excrete elevated concentrations of urine $\mathrm{U}$ as a function of the DU fragment burden. A high exposure group was defined as having current urine $\mathrm{U}$ concentrations $\geq 0.1 \mu \mathrm{g} \mathrm{U} / \mathrm{g}$ creatinine. The maximum measured concentration of urinary $\mathrm{U}$ was $60 \mu \mathrm{g} \mathrm{U} / \mathrm{g}$ creatinine. Differences between the high and low exposure groups were compared. Although subtle trends are suggested with regard to renal proximal tubular function and bone formation, the high exposure cohort exhibits few clinically significant U-related health effects. Of 17 laboratory biomarker parameters for renal effects, only five approached statistical significance, with $p \leq 0.11$. Differences between the high and low exposure groups for two of these five parameters were in the expected direction, and three were in the opposite direction expected. The report did not address the presence or absence of casts in the urine (McDiarmid, et al. 2009).

Results of animal studies suggest that mild renal injury with transient elevation in urinary biochemical indices may occur in chronically exposed animals at renal uranium concentrations of a few tenths of a microgram U per gram kidney (Leggett 1989, Foulkes 1990). The return of the biochemical indices to normal during chronic exposure may reflect a kind of acquired tolerance to uranium associated with structural changes in the luminal surfaces of regenerated kidney tubule cells (Leggett 1989). Several reviewers have suggested that the traditional chemical guidance level for uranium of $3 \mu \mathrm{g} \mathrm{U} / \mathrm{g}$ kidney should be reduced, particularly for consideration of chronic exposures (Morrow et al. 1982, Wrenn et al. 1985, Morrow 1984, Sula et al. 1989, Leggett 1989, SuLu and Zhao 1990, Foulkes 1990). Guidance values in the range $0.3-1 \mu \mathrm{g} \mathrm{U} / \mathrm{g}$ kidney have been proposed.

Established methods for assigning limits for exposure to hazardous chemicals were taken into account in the selection of the reference primary guidance levels for the chemical toxicity of 
uranium. Chou and Pohl (2005) have explained the derivation of standards based on renal injury used by two Federal agencies. They write:

...the U.S. Health and Human Services' Agency for Toxic Substances and Disease Registry (ATSDR) derives minimal risk levels (MRLs)... an MRLs is an estimate of the daily human exposure to a hazardous substance that is likely to be without appreciable risk of adverse non-cancer health effects over a specified duration of exposure...MRLs are derived using the no-observed-adverse-effect level/uncertainty factor (NOAEL/UF) approach. They are used for acute (1-14 days), intermediate (15-364 days), and chronic (365 days and longer) exposure durations, and for the oral and inhalation routes of exposure. MRLs are based on non-cancer health end points... and are derived based on the highest NOAEL, or in the absence of a NOAEL, the lowest less-serious lowest-observedadverse-effect level (LOAEL) for the most sensitive health effect end point for a given route and exposure duration in the database. Uncertainty factors (UFs) are applied to account for human variability, for use of a LOAEL, for interspecies extrapolation when animal studies are used in the absence of adequate human data, and for extrapolation across exposure duration.

The U.S. Environmental Protection Agency (EPA) also derives health-based guidance values for hazardous chemicals; EPA's values are called reference concentrations (RfCs) and reference doses (RfDs) for inhalation and oral exposures, respectively...ATSDR derived an intermediate-duration oral MRL of $0.002 \mathrm{mg} / \mathrm{kg} /$ day for highly soluble uranium salts. If extrapolated to chronic exposure, this MRL would be one order of magnitude lower than the RfD. ...ATSDR used a LOAEL of $0.05 \mathrm{mg} / \mathrm{kg} /$ day in rabbits from the [Gilman et al. 1998] study and a UF [uncertainty factor] of 30, whereas EPA derived the RfD for soluble uranium salts of $0.003 \mathrm{mg} / \mathrm{kg} /$ day using a LOAEL of $2.8 \mathrm{mg} / \mathrm{kg} /$ day and a UF of 1000 on the basis of a 30-day oral bioassay in rabbits by [Maynard and Hodge 1949].

The U.S. Nuclear Regulatory Commission likely based its occupational limit for U in 10 CFR 20.1201 (e) and10 CFR 20 Appendix B, Footnote 3 on recommendations in ICRP Publication 2 (ICRP 1959).

The availability of human data from the literature review, especially data from the Gulf War I veterans, provide for the establishment of a reference guidance level on the LOAEL basis. We take subtle changes in the renal proximal tubular function, including the presence of urinary casts (Luessenhop, et al. 1958, Kathern and Moore, 1986), as the LOAEL indicators. We calculate from reference man data (ICRP 2002) and the method illustrated in Example 5.5 of this report that the high exposure group of the Gulf War I veterans (McDiarmid, et al. 2009) have a concentration of $U$ ranging from 0.001 to $0.7 \mu \mathrm{g} U / \mathrm{g}$ kidney. Given that there were transient effects at the upper end of these levels and the data are subject to interpretation, it appears that the upper end of this range is on the cusp between a NOAEL and a LOAEL. These data are consistent with the conclusion of the U.S. National Research Council that transient adverse renal effects of uranium including proteinuria and glucosuria may occur at peak kidney concentrations as low as $1.0 \mu \mathrm{g} \mathrm{U} / \mathrm{g}$ kidney, as noted above. 
In this report, the concentration $1.0 \mu \mathrm{g} \mathrm{U} / \mathrm{g}$ kidney is adopted as the reference primary guidance level for prevention of chemical toxicity. This value is used to derive immediate action levels in terms of measurable quantities such as the concentration of uranium in air or the concentration of uranium in urine. The equilibrium value $0.3 \mu \mathrm{g} \mathrm{U} / \mathrm{g}$ kidney is used to derive investigation levels in terms of measurable quantities.

\section{$\underline{\text { Reference primary guidance for prevention of chemical toxicity from intake of uranium: }}$}

\section{The concentration of uranium in the kidneys should not exceed $1.0 \mu \mathrm{g} \mathrm{U} / \mathrm{g}$ kidney at any time.}

\subsection{Reference Primary Guidance for Uranium as a Radiation Hazard}

To place all ionizing radiations on a common scale with regard to their potential health detriment, the ICRP uses quantities called the equivalent dose and the effective dose. The equivalent dose is the absorbed dose averaged over an organ or tissue and multiplied by a radiation weighting factor that reflects the relative biological effectiveness of the type (and energy in the case of neutrons) of radiation causing the dose. The effective dose takes into account that the relationship between equivalent dose and the probability of radiogenic effects depends on the organ or tissue irradiated. The effective dose is a weighted sum of equivalent doses to radiosensitive tissues, with the tissue weighting factor representing the relative contribution of that tissue to the total detriment for the case of uniform irradiation of the whole body.

The concept of effective dose (equivalent) was introduced in ICRP Publication 26 (1977), along with weighting factors for radiosensitive tissues and primary guidance levels concerning acceptable doses from occupational intakes. Radiogenic health effects were categorized as stochastic, meaning that the probability of occurrence is a function of dose (e.g., cancer or genetic disorders), or nonstochastic, meaning that the effect is expected to occur when the dose reaches or exceeds a threshold value (e.g., acute radiation syndrome or the formation of cataracts). To prevent nonstochastic effects, the dose equivalent (referred to as the equivalent dose in later ICRP documents) to body organs from intakes in a year was limited to $0.5 \mathrm{~Sv}$, except that the lens of the eye was limited to $0.15 \mathrm{~Sv}$. To constrain the occurrence of stochastic effects, the effective dose to the body from exposures or intakes in a year was limited to $0.05 \mathrm{~Sv}$, although averaging over periods considerably longer than a year was acceptable.

ICRP Publication 26 was superseded by ICRP Publication 60 (ICRP 1991). The guidance in Publication 60 is also based on the concept of effective dose, but revised weighting factors and a revised limit on the effective dose are provided to reflect later information on the effects of radiation exposures. Guidance is provided in ICRP Publication 60 for prevention of nonstochastic effects, but that guidance is usually less restrictive than the guidance for stochastic effects. ICRP Publication 60 limits the effective dose (50-y integral) to $0.02 \mathrm{~Sv}$ per year (i.e., from intake during a 1-y period) averaged over defined periods of five years and $0.05 \mathrm{~Sv}$ in any single year. The value $0.02 \mathrm{~Sv}$ rather than $0.05 \mathrm{~Sv}$ is intended for planning purposes, even for 1y periods. 
ICRP Publication 60 was recently superseded by ICRP Publication 103 (2008). The primary guidance in ICRP Publication 60 summarized in the preceding paragraph was retained in ICRP Publication 103.

In this report, an annual effective dose of $0.02 \mathrm{~Sv}$ is adopted as the reference primary guidance level for control of radiation effects from intake of uranium. The same value is used to derive investigation levels in terms of measurable quantities such as the concentration of uranium in air or the concentration of uranium in urine. An annual effective dose of $0.05 \mathrm{~Sv}$ is used to derive immediate action levels in terms of measurable quantities.

Reference primary guidance for limitation of radiation effects from intake of uranium:

The annual effective dose from intake of uranium should not exceed $0.02 \mathrm{~Sv}$ as an average over any 5-y period and should not exceed $0.05 \mathrm{~Sv}$ in any single year. The value $0.02 \mathrm{~Sv}$ for intake during any 1-y period should be used for planning purposes. 



\section{BIOKINETIC MODELS USED TO DERIVE SECONDARY REFERENCE GUIDANCE LEVELS FOR EXPOSURE TO URANIUM}

\subsection{Respiratory Kinetics}

\subsubsection{General Features of the ICRP's Human Respiratory Tract Model}

The ICRP's Human Respiratory Tract Model (HRTM) was introduced in ICRP Publication 66 (1994a). Default parameter values describing deposition, retention, translocation, and absorption of inhaled particles or gases are provided in Publication 66, but material-specific parameter values may be substituted when information allows.

The compartments of the HRTM and the paths of mechanical clearance of deposited particles are shown in Figure 3.1. Reference values for particle transport rate constants are shown beside the arrows and are in units of $\mathrm{d}^{-1}$. The rates of particle transport are assumed to be independent of particle size.

Particle transport is in competition with the dissolution of particles, which determines the rate of absorption of the contained radionuclide to blood. Dissolution models used in conjunction with the particle transport model shown in Figure 3.1 are described below. Absorption to blood is assumed to occur from all respiratory compartments except $\mathrm{ET}_{1}$. This is in addition to activity that is absorbed to some extent from the alimentary tract after it is escalated from the lungs and swallowed. The total absorption of activity to blood from the respiratory and alimentary tracts determines the level of urinary excretion of activity.

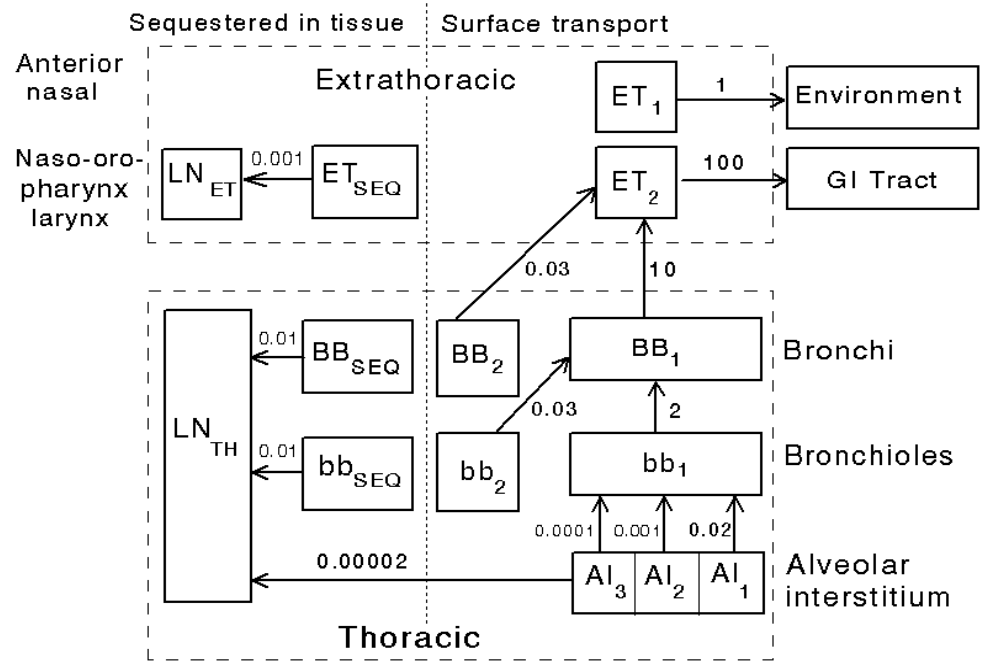

Figure 3.1 Structure of the ICRP's respiratory tract model (ICRP 1994a). The numbers adjacent to the arrows indicate particle transport rates $\left(\mathrm{d}^{-1}\right)$. Absorption to blood is assumed to occur from all respiratory compartments except ET $_{1}$. Abbreviations: $\mathbf{A I}=$ alveolar interstitium, 


\section{$\mathrm{BB}=$ bronchi, $\mathrm{bb}=$ bronchioles, $\mathrm{ET}=$ extrathoracic, $\mathrm{LN}=$ lymph nodes, $\mathrm{SEQ}=$ sequestered , and}

TH $=$ thoracic.

The HRTM divides the respiratory system into extrathoracic (ET) and thoracic tissues. The airways of the ET region are further divided into the anterior nasal passages in which deposits are removed by extrinsic means such as nose blowing and the posterior nasal passages (nasopharynx, oropharynx, and the larynx) from which deposits are swallowed or absorbed to blood. The airways of the thorax include the bronchi (BB), bronchioles (bb), and alveolar interstitium (AI). Uranium or other material deposited in the thoracic airways is cleared into blood by absorption, to the gastrointestinal tract by mechanical processes (i.e., transported upward and swallowed), and to the regional lymph nodes via lymphatic channels.

The dissolution rate depends on the chemical and physical form of the inhaled element. Dissolved activity generally is assumed to be immediately absorbed to blood, although the HRTM allows for binding of dissolved activity to tissues of the respiratory tract and gradual absorption of bound activity to blood when indicated by specific information. Absorption is assumed to occur at the same rate in all regions of the respiratory tract except $\mathrm{ET}_{1}$, where it is assumed that no absorption takes place. The ICRP's default parameter values for relatively soluble, moderately soluble, and relatively insoluble aerosols imply that the absorption rate decreases with time. A level absorption rate or an increasing absorption rate may be assigned.

The dissolution-absorption model within the HRTM is shown in Figure 3.2. This is a first-order model that is designed to depict a time-dependent rate of absorption to blood. This model applies to each compartment of the respiratory tract other than $\mathrm{ET}_{1}$, from which there is assumed to be no absorption. All of the deposit in the respiratory tract is initially assigned to a compartment representing an initial state, i.e., an initial rate of dissolution of inhaled particles in the respiratory tract. Material in the initial state dissolves at the rate $s_{p}$ but is simultaneously transformed in undissolved form at the rate $s_{p t}$ to a material with a different dissolution rate $s_{t}$. A fraction $f_{b}$ of activity dissolved from particles either in the initial state or the transformed state enters a respiratory tissue compartment called "Bound material" and a fraction $1-\mathrm{f}_{\mathrm{b}}$ goes directly to blood. Activity transfers from the bound state to blood at the rate $\mathrm{s}_{\mathrm{b}}$.

The implementation of the dissolution-absorption model shown in Figure 3.2 is illustrated using the bronchiolar compartment identified in Figure $3.1 \mathrm{as} \mathrm{b}_{2}$. A compartment with the same name $\left(b_{2}\right)$ is used to represent the initial state of material in $b_{2}$, and a compartment named $b_{2}$ - $T$ (not shown in Figure 3.1) is used to represent the transformed state of that material at the same location in the respiratory tract. The change of material at this location from the initial state to the transformed state is represented by a transfer coefficient from $b_{2}$ to $b_{2}-T$. The transfer coefficient from $b_{b}$ to $b_{b_{2}}-T$ is the value $s_{p t}$ indicated in Figure 3.2. The transfer coefficient describing absorption from the initial state compartment $b_{2}$ to blood is $\left(1-f_{b}\right) s_{p}$, and the transfer coefficient describing absorption from the transformed state compartment $\mathrm{bb}_{2}-\mathrm{T}$ to blood is $\left(1-f_{b}\right) s_{t}$. The transfer coefficients from $b_{2}$ and $b_{2}$-T to the "bound" compartment within the bronchiolar region are $f_{b} s_{p}$ and $f_{b} s_{t}$, respectively. The particle transport rate $0.03 \mathrm{~d}^{-1}$ from $b_{2}$ to $\mathrm{BB}_{1}$ shown in Figure 3.1 is used as both the transfer coefficient from the transformed state compartment $\mathrm{bb}_{2}-\mathrm{T}$ to the transformed state compartment $\mathrm{BB}_{1}-\mathrm{T}$ and the transfer coefficient from the initial state compartment $\mathrm{bb}_{2}$ to the initial state compartment $\mathrm{BB}_{1}$. 


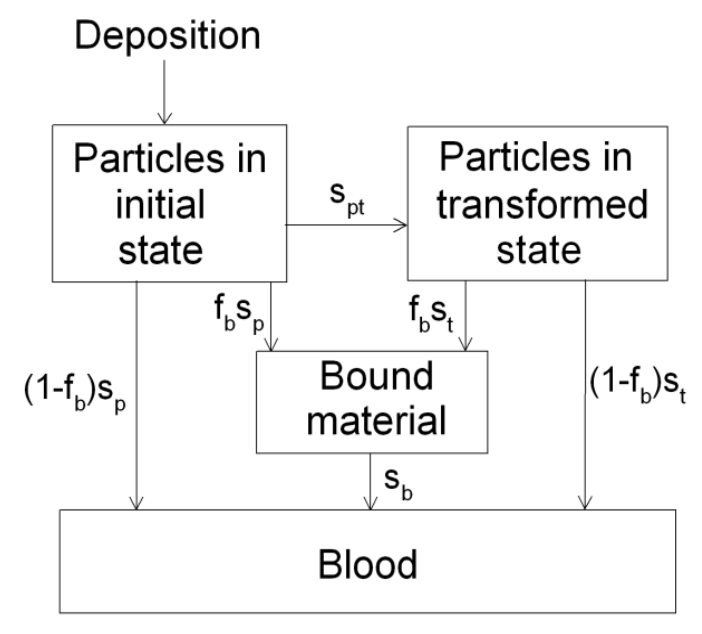

Figure 3.2 Model within the HRTM describing time-dependent absorption to blood. Inhaled material deposited in the respiratory tract initially dissolves at rate $s_{p}$. Dissolution is in competition with transformation at rate $s_{p t}$ to a material with dissolution rate $s_{t}$. Fractions $1-f_{b}$ and $f_{b}$ of dissolved activity enter blood and bind to respiratory tissues, respectively. Activity transfers from the bound state to blood at the rate $s_{b}$.

The compartment in Figure 3.2 labeled "Bound material" is rarely used due to lack of information on binding of dissolved activity to respiratory tissues. For most practical purposes the dissolution-absorption model shown in Figure 3.2 can be reduced to the simpler model shown in Figure 3.3.

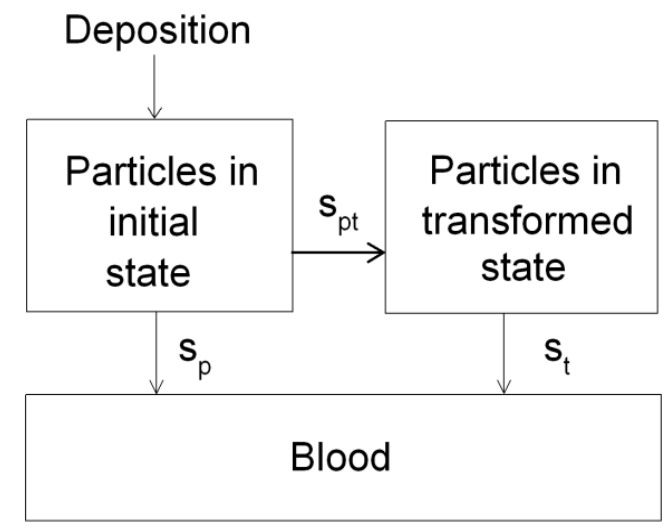

Figure 3.3 Simplification of the model of time-dependent absorption to blood by removal of the compartment "Bound material". All of the deposit is assigned to a compartment labeled "Particles in initial state". Material is transferred from this compartment to body fluids at rate $s_{p}$ (absorption) and to a compartment called "Particles in transformed state" at rate $s_{p t}$. Particles in the transformed state have a different absorption rate $s_{t}$. 
If the dissolution rate decreases with time as is often the case, the model shown in Figure 3.3 may be replaced by the even simpler model shown in Figure 3.4. In the latter model, which is the most commonly used version, it is assumed that a fraction $\mathrm{f}_{\mathrm{r}}$ of deposited material dissolves at the relatively fast rate $\mathrm{s}_{\mathrm{r}}$ and the remaining fraction $1-\mathrm{f}_{\mathrm{r}}$ dissolves more slowly at the rate $\mathrm{s}_{\mathrm{s}}$. The relatively soluble and less soluble fractions are assigned to separate compartments upon deposition. The models shown in Figures 3.3 and 3.4 give the same results when the two sets of parameter values are related as follows:

$$
\begin{gathered}
s_{p}=s_{s}+f_{r}\left(s_{r}-s_{s}\right) \\
s_{p t}=\left(1-f_{r}\right)\left(s_{r}-s_{s}\right) \\
s_{t}=s_{s}
\end{gathered}
$$

These relations are useful because material-specific dissolution rates usually are reported in terms of the model shown in Figure 3.4, and some computer applications of the HRTM are based on the more general model shown in Figure 3.3.

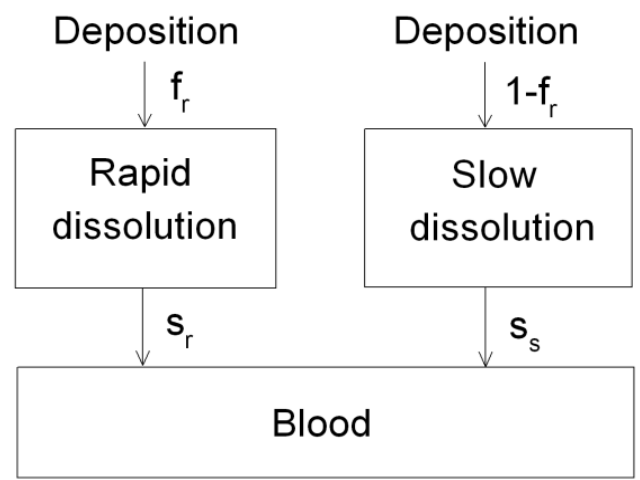

Figure 3.4 Model of time-dependent absorption within the HRTM generally applied when the dissolution rate of the material decreases with time. Fractions $f_{r}$ and 1- $f_{r}$ of deposited material have different dissolution rates $\left(s_{\mathrm{r}}\right.$ and $s_{\mathrm{s}}$, respectively).

In most applications of the HRTM, inhaled particulate material is assigned to one of three generic absorption types: Type F, representing fast dissolution and a high level of absorption to blood; Type M, representing a moderate rate of dissolution and an intermediate level of absorption to blood; and Type $S$, representing slow dissolution and a low level of absorption to blood. In terms of the ICRP's dissolution model as depicted in Figure 3.4, Type F has dissolution parameters $f_{r}=1$ (i.e., there is no slow dissolution fraction) and $s_{r}=100 d^{-1}$; Type $M$ has dissolution parameters $\mathrm{f}_{\mathrm{r}}=0.1, \mathrm{~s}_{\mathrm{r}}=100 \mathrm{~d}^{-1}$, and $\mathrm{s}_{\mathrm{s}}=0.005 \mathrm{~d}^{-1}$; and Type $\mathrm{S}$ has dissolution parameters $\mathrm{f}_{\mathrm{r}}=0.001, \mathrm{~s}_{\mathrm{r}}=100 \mathrm{~d}^{-1}$, and $\mathrm{s}_{\mathrm{s}}=0.0001 \mathrm{~d}^{-1}$. Each of these parameter values is applied to each respiratory compartment shown in Figure 3.1, except $\mathrm{ET}_{1}$, to define the absorption rate to blood from that compartment. The user selects Type F, M, or S based either on ICRP recommendations or independent interpretation of site-specific data and information from the literature. 


\subsubsection{Application of the HRTM to Various Forms of Uranium}

The pattern of clearance of uranium from the respiratory tract has been studied frequently in laboratory animals and uranium workers following inhalation of various forms of uranium. Also, the rate of dissolution in simulated lung fluid has been determined for different forms of uranium. The collective data provide a basis for assigning default absorption types (Type F, Type M, or Type S) to commonly encountered uranium compounds.

The default absorption types given in Table 3.1 may be applied to the indicated forms of uranium in the absence of specific information. In cases where data from different studies are inconsistent, the assigned absorption type represents the most frequently observed pattern if evident. Where data are too limited to assign a most frequently observed pattern, the intermediate absorption type, Type $\mathrm{M}$, is assigned as a method of avoiding large under- or overestimates of residence time in the lungs and absorption to blood. 
Table 3.1 Default absorption types for different forms of airborne uranium ${ }^{a}$

\begin{tabular}{|c|c|c|c|}
\hline Inhaled form & Default type & Comments & References \\
\hline $\begin{array}{l}\text { Uranyl nitrate } \\
\left(\mathrm{UO}_{2}\left(\mathrm{NO}_{3}\right)_{2}\right)\end{array}$ & $\mathrm{F}$ & $\begin{array}{l}\text { Widely encountered in aqueous solution } \\
\text { in nuclear fuel fabrication and } \\
\text { reprocessing. Type F behavior is most } \\
\text { frequently observed for uranyl nitrate } \\
\text { but Type M behavior is suggested by } \\
\text { some data. }\end{array}$ & $\begin{array}{l}\text { Cook and Holt 1974; } \\
\text { Cooper et al. 1982; } \\
\text { Ballou et al. 1986; } \\
\text { Ellender 1987; } \\
\text { Stradling et al. 1991; } \\
\text { Eidson 1994; } \\
\text { Hodgson et al. } 2000\end{array}$ \\
\hline $\begin{array}{l}\text { Uranium } \\
\text { dioxide }\left(\mathrm{UO}_{2}\right)\end{array}$ & $S$ & $\begin{array}{l}\text { Final product in the manufacture of } \\
\text { nuclear fuel pellets and also present as } \\
\text { depleted uranium in mixed oxide fuel } \\
\text { (MOX). Human, animal, and in vitro } \\
\text { data indicate low solubility of } \mathrm{UO}_{2} \text { in } \\
\text { lungs. See } \mathrm{UO}_{2} \text {-specific dissolution } \\
\text { rates in Table 3.2. }\end{array}$ & $\begin{array}{l}\text { Leach et al. 1973; } \\
\text { Cook and Holt 1974; } \\
\text { Pomroy and Noel 1981; } \\
\text { Schieferdecker et al. 1985; } \\
\text { Price 1989; } \\
\text { Stradling et al. 1989b; } \\
\text { Métivier et al. 1992; } \\
\text { Eidson 1994; } \\
\text { Chazel et al. 2000b; } \\
\text { Ansoborlo et al. 2002; } \\
\text { Stradling et al. 2002 }\end{array}$ \\
\hline $\begin{array}{l}\text { Uranium } \\
\text { trioxide }\left(\mathrm{UO}_{3}\right. \\
\text { or } \\
\left.\mathrm{UO}_{3} \cdot \mathrm{nH}_{2} \mathrm{O}\right)\end{array}$ & M & $\begin{array}{l}\text { Formed by heating uranyl nitrate, which } \\
\text { in the fuel fabrication cycle is then } \\
\text { reduced to form } \mathrm{UO}_{2} \text {. Behavior of } \mathrm{UO}_{3} \\
\text { is sensitive to the hydration state, and } \\
\text { its solubility depends on the parameter } \\
\text { n. Rat data indicate either Type } \mathrm{F} \text { or } \\
\text { Type } \mathrm{M} \text { behavior. }\end{array}$ & $\begin{array}{l}\text { Harris 1961; } \\
\text { Morrow et al. 1972; } \\
\text { Cook and Holt 1974; } \\
\text { Eidson 1994; } \\
\text { Ansoborlo et al. 2002; } \\
\text { Stradling et al. 2002 }\end{array}$ \\
\hline $\begin{array}{l}\text { Uranium } \\
\text { octoxide } \\
\left(\mathrm{U}_{3} \mathrm{O}_{8}\right)\end{array}$ & M & $\begin{array}{l}\text { Present in yellowcake and also occurs } \\
\text { in later stages of the uranium fuel cycle. } \\
\text { Occupational, animal, and in vitro data } \\
\text { available. Dissolution rate is variable } \\
\text { and apparently dependent on the } \\
\text { process of manufacture. Most data are } \\
\text { consistent with Type } \mathrm{M} \text { but Type } \mathrm{S} \text { is } \\
\text { sometimes indicated. See } \mathrm{U}_{3} \mathrm{O}_{8^{-}} \\
\text {specific dissolution rates in Table } 3.2 \text {. }\end{array}$ & $\begin{array}{l}\text { Cook and Holt 1974; } \\
\text { West et al. 1979; } \\
\text { Eidson and Mewhinney 1980; } \\
\text { Chalabreysse et al. 1989; } \\
\text { Stradling et al. 1989a, 2002; } \\
\text { Eidson 1990, 1994; } \\
\text { Métivier et al. 1992; } \\
\text { Barber and Forrest 1995; } \\
\text { Ansoborlo et al. 1998b, 2002; } \\
\text { Chazel et al. } 1998\end{array}$ \\
\hline $\begin{array}{l}\text { Uranium } \\
\text { peroxide } \\
\text { hydrate }\left(\mathrm{UO}_{4}\right. \\
\left.\text { or } \mathrm{UO}_{4} \cdot \mathrm{nH}_{2} \mathrm{O}\right)\end{array}$ & $\mathrm{F}$ & $\begin{array}{l}\text { Present at one stage of uranium fuel } \\
\text { cycle and consists of small needles with } \\
\text { AMAD near } 1 \mu \mathrm{m} \text {. Type } \mathrm{F} \text { behavior } \\
\text { indicated by rat data. See } \mathrm{UO}_{4} \text {-specific } \\
\text { dissolution rates in Table } 3.2 . .\end{array}$ & Ansoborlo et al. 1998a \\
\hline
\end{tabular}


Table 3.1 (continued)

\begin{tabular}{|c|c|c|c|}
\hline Inhaled form & Default type & Comments & References \\
\hline $\begin{array}{l}\text { Uranium } \\
\text { tetrafluoride } \\
\left(\mathrm{UF}_{4}\right)\end{array}$ & $\mathrm{M}$ & $\begin{array}{l}\text { An intermediate product in the uranium } \\
\text { fuel cycle. Can be reduced to uranium } \\
\text { metal or oxidized by fluorine to form } \\
\mathrm{UF}_{6} \text {. Animal studies indicate Type F or } \\
\text { Type M; in vitro solubility studies } \\
\text { indicate Type } \mathrm{M} \text {. See } \mathrm{UF}_{4} \text {-specific } \\
\text { dissolution rates in Table } 3.2 . \text {. }\end{array}$ & $\begin{array}{l}\text { Cook and Holt 1974; } \\
\text { Stradling et al. 1985, 2002; } \\
\text { Chalabreysse et al. 1989; } \\
\text { André et al. 1989; } \\
\text { Ansoborlo et al. 1990, 2002; } \\
\text { Eidson 1994; Chazel et al. } \\
\text { 2000a }\end{array}$ \\
\hline $\begin{array}{l}\text { Uranium } \\
\text { hexafluoride } \\
\left(\mathrm{UF}_{6}\right)\end{array}$ & $\mathrm{F}$ & $\begin{array}{l}\text { Exists in vapor form but in presence of } \\
\text { water in the atmosphere or respiratory } \\
\text { tract is converted to uranyl fluoride } \\
\left(\mathrm{UO}_{2} \mathrm{~F}_{2}\right) \text { aerosol. Exposure likely to } \\
\text { involve both chemical forms } \\
\text { simultaneously and also hexafluoride } \\
\text { fumes. Rapid absorption from lungs to } \\
\text { blood indicated accidental human } \\
\text { exposures and animal and in vitro data. }\end{array}$ & $\begin{array}{l}\text { Cook and Holt 1974; } \\
\text { Boback 1975; } \\
\text { Morrow et al. 1982; } \\
\text { Moore and Kathren 1985; } \\
\text { Beau and Chalabreysse 1989; } \\
\text { Fisher et al. 1991; } \\
\text { Eidson 1994; } \\
\text { Bailey and Davis } 2002\end{array}$ \\
\hline $\begin{array}{l}\text { Uranyl Tri- } \\
\text { Butyl- } \\
\text { Phosphate } \\
\text { (U-TBP) }\end{array}$ & $\mathrm{F}$ & $\begin{array}{l}\text { Used as extractant in nuclear fuel } \\
\text { fabrication and for separation of } U \text { and } \\
\text { Pu during reprocessing. }\end{array}$ & $\begin{array}{l}\text { Pellow et al. 1996; } \\
\text { Stradling et al. } 2002\end{array}$ \\
\hline $\begin{array}{l}\text { Vaporized } \\
\text { uranium metal }\end{array}$ & M & $\begin{array}{l}\text { Method of } \mathrm{U} \text { enrichment based on laser } \\
\text { isotopic separation can produce three } \\
\text { types of aerosols identified as variable } \\
\text { mixtures of } \mathrm{U} \text { metal, } \mathrm{UO}_{2} \text {, and } \mathrm{U}_{3} \mathrm{O}_{8} \text {. } \\
\text { Rat studies suggest Type } \mathrm{M} \text { behavior. }\end{array}$ & Ansoborlo et al. $1998 \mathrm{~b}$ \\
\hline $\begin{array}{l}\text { Uranium ore } \\
\text { dust }\end{array}$ & M & $\begin{array}{l}\text { Often variable mixtures of relatively } \\
\text { soluble and insoluble fractions. } \\
\text { Moderate solubility indicated by some } \\
\text { in vitro data. Human exposure data } \\
\text { indicate extended lung retention of } \\
\text { portion of intake. }\end{array}$ & $\begin{array}{l}\text { Kalkwarf 1979; } \\
\text { Fisher et al. 1982; } \\
\text { Alexander et al. 1986; } \\
\text { Duport et al. 1991; } \\
\text { Eidson } 1994\end{array}$ \\
\hline $\begin{array}{l}\text { Ammonium } \\
\text { diuranate } \\
(\mathrm{ADU}) \\
\left(\left(\mathrm{NH}_{4}\right)_{2} \mathrm{U}_{2} \mathrm{O}_{7}\right)\end{array}$ & M & $\begin{array}{l}\text { A component of yellowcake. Rat } \\
\text { studies data indicate moderate solubility } \\
\text { in lungs. In vitro data are variable and } \\
\text { indicate relatively fast to moderate } \\
\text { solubility. }\end{array}$ & $\begin{array}{l}\text { Galibin and Parfenov 1971; } \\
\text { Cook and Holt 1974; } \\
\text { Boback 1975; } \\
\text { Eidson and Mewhinney 1980; } \\
\text { Damon et al. 1984; } \\
\text { Stradling et al. 1987, 2002; } \\
\text { Eidson 1994; } \\
\text { Ansoborlo et al. } 2002\end{array}$ \\
\hline
\end{tabular}


Table 3.1 (continued)

\begin{tabular}{|c|c|c|c|}
\hline Inhaled form & Default type & Comments & References \\
\hline Yellowcake & $\mathrm{M}$ & $\begin{array}{l}\text { Yellowcake is a complex mixture of } \\
\text { diuranates, uranyl sulfate, and hydrated } \\
\text { uranium oxides and contains } 70-90 \% \\
\text { uranium. The main component is } \mathrm{U}_{3} \mathrm{O}_{8} \text {. } \\
\text { In vitro studies indicate dissolution rate } \\
\text { varies with mixture of materials and } \\
\text { preparation process. Differences found } \\
\text { in dissolution rates of low-fired } \\
\text { yellowcake (dried at less than } 400^{\circ} \mathrm{C} \text { ) } \\
\text { and high-fired (calcined) yellowcake } \\
\text { (dried at } 400+^{\circ} \mathrm{C} \text { ). See material- } \\
\text { specific dissolution rates in Table 3.2. }\end{array}$ & $\begin{array}{l}\text { Eidson and Mewhinney 1980; } \\
\text { Dennis et al. 1982; } \\
\text { Alexander et al. 1986; } \\
\text { Canu et al. } 2008\end{array}$ \\
\hline $\begin{array}{l}\text { Uranium } \\
\text { aluminide } \\
\left(\mathrm{UAl}_{\mathrm{x}}\right)\end{array}$ & S & $\begin{array}{l}\text { Experience at one site indicates initially } \\
\text { low solubility followed by rapid } \\
\text { dissolution a few months after intake. } \\
\text { Material-specific parameter values are } \\
\text { given in Leggett et al. } 2005 \text {. }\end{array}$ & Leggett et al. 2005 \\
\hline $\begin{array}{l}\text { Uranyl } \\
\text { carbonate } \\
\text { complexes }\end{array}$ & M & $\begin{array}{l}\text { Little direct information. Theoretical } \\
\text { considerations indicate these complexes } \\
\text { generally may be stable at the } \mathrm{pH} \text { of } \\
\text { lung fluid but may break down at the } \\
\mathrm{pH} \text { of gastric fluid. Data for rats } \\
\text { indicate respiratory kinetics broadly } \\
\text { similar for uranyl nitrate and } \\
\text { bicarbonate but lung retention of } \\
\text { bicarbonate is slightly greater. }\end{array}$ & $\begin{array}{l}\text { Ellender 1987; } \\
\text { USEPA 1999a, 1999b; } \\
\text { Sutton and Burastero } 2004\end{array}$ \\
\hline
\end{tabular}

${ }^{a}$ For use in the absence of specific information on the in vivo or in vitro solubility of the inhaled material.

Inhalation of uranyl carbonate complexes has received little attention in radiation protection but is an important consideration for workers involved in extraction or processing of uranium mined by in situ leaching techniques. With these techniques uranium ores are leached underground by the introduction of a solvent solution, called a lixiviant, through injection wells drilled into the ore body. Lixiviants used in U.S. operations often consist of water containing added oxygen and carbon dioxide or sodium bicarbonate, which mobilize uranium. The injected lixiviant passes through the ore body and mobilizes the uranium, and the uranium-bearing solution is pumped to the surface. In a carbonate leach system the uranium would be complexed as uranyl carbonate. The pregnant leach solution is processed to extract the uranium, usually by ion exchange or by solvent extraction. The uranium in the pregnant lixiviant conceivably could pose an inhalation exposure hazard if the material were accidentally released, particularly indoors. For example, the material could be released due to a pipe or valve failure during processing of the pregnant lixiviant. Type $\mathrm{M}$ is recommended in Table 3.1 as a most likely or default absorption type for uranyl carbonate, but to derive a worst-case dose one could assume Type $\mathrm{S}$ behavior in the 
respiratory tract. Theoretical considerations suggest, however, that uranyl carbonate complexes are likely to break down in the acid environment of the stomach (USEPA, 1999a, 1999b; Sutton and Burastero, 2004). Even if one assumes Type $S$ behavior, the gastrointestinal uptake fraction for soluble uranium (0.02) should be applied to uranium escalated up the respiratory tract and swallowed, rather than the value 0.002 applied by the ICRP to inhaled uranium of Type $S$.

Material-specific parameter values have been proposed in the literature for some forms of uranium. These have been based on in vitro dissolution studies, animal studies, or relatively detailed follow-up of cases with elevated intakes of known forms of uranium. Material-specific parameter values formulated in terms of the model shown in Figure 3.4 are summarized in Table 3.2. The materials addressed are $\mathrm{U}_{3} \mathrm{O}_{8}$ from manufacturing of enriched pellets; industrial $\mathrm{UO}_{2}$ from mixed oxide (MOX) fuel manufacturing; $\mathrm{UF}_{4}$, used in the hexafluoride process; $\mathrm{UO}_{4}$, an intermediate compound in the uranium fuel cycle; low-fired yellowcake (dried at less than $400^{\circ}$ ); and high-fired yellowcake (dried at higher temperatures). Also included for comparison in Table 3.2 are the corresponding parameter values for the three default absorption types:

Type F, Type M, and Type S.

Table 3.2 Default and material-specific parameter values of the model shown in Figure 3.4, representing time-dependent dissolution rates of uranium compounds ${ }^{a}$

\begin{tabular}{|c|c|c|c|}
\hline Material & $\mathbf{f}_{\mathbf{r}}$ & $S_{r}\left(d^{-1}\right)$ & $S_{s}\left(d^{-1}\right)$ \\
\hline Type F & 1.0 & 100 & - \\
\hline Type M & 0.1 & 100 & 0.005 \\
\hline Type S & 0.001 & 100 & 0.0001 \\
\hline $\mathrm{U}_{3} \mathrm{O}_{8}$ & 0.017 & 2.6 & 0.00037 \\
\hline $\mathrm{UO}_{2}$ & 0.03 & 1.25 & 0.0015 \\
\hline $\mathrm{UF}_{4}$ & 0.58 & 0.21 & 0.0026 \\
\hline $\mathrm{UO}_{4}$ & 0.87 & 0.93 & 0.024 \\
\hline $\begin{array}{l}\text { Yellowcake } \\
\left.\text { (low-fired }^{b}\right)\end{array}$ & 0.61 & 0.87 & 0.017 \\
\hline $\begin{array}{l}\text { Yellowcake } \\
\text { (high-fired }^{b} \text { ) }\end{array}$ & 0.35 & 0.7 & 0.0035 \\
\hline
\end{tabular}

Material-specific parameter values given in the literature, including ICRP documents, must be used with caution. It should be kept in mind that the dissolution rate of some materials depends on factors that may differ from site to site, such as the process of formation of the material.

In general, a choice between the ICRP's default parameter values and material-specific parameter values should reflect the level of information available on the material to which workers are being exposed. As a rule of thumb, material-specific parameter values should be applied only when there is strong information on the dissolution properties of a material and high 
confidence that the workers were exposed mainly to that material. Application of a given default absorption type requires only broad information on the solubility properties of an inhaled material. If information is insufficient to decide whether an inhaled material is best described as relatively soluble (Type F), moderately soluble (Type $M$ ), or relatively insoluble (Type S), then comparison with exposure limits should be based on the most restrictive of the three default absorption types with regard to the case of interest.

\subsubsection{Typical Sizes of Airborne Particles in Work Environments}

The aerodynamic diameter of a particle is defined as the diameter of a unit-density sphere having the same terminal settling velocity as that particle. In ICRP documents, particle sizes generally are expressed in terms of the activity median aerodynamic diameter (AMAD), defined as the aerodynamic diameter of an aerosol particle whose activity is the median for the aerosol.

The default particle size recommended by the ICRP for estimation of doses from inhalation of particulate aerosols in the workplace is $5 \mu \mathrm{m}$ AMAD (ICRP 1994b). This value was based on a survey of published values of AMAD measured in working environments (Dorrian and Bailey 1995). Results compiled from 52 studies indicated a range of 0.12-20 $\mu \mathrm{m}$ AMAD for operations involving uranium and $0.12-25 \mu \mathrm{m}$ AMAD for all work environments. The collected data were fit reasonably well by a lognormal distribution with a median value of $4.4 \mu \mathrm{m}$. Data from both the nuclear power and nuclear fuel handling industries gave a median value of about $4 \mu \mathrm{m}$. Data from uranium mills gave a median value of about $7 \mu \mathrm{m}$ with AMADs sometimes exceeding $10 \mu \mathrm{m}$. High temperature and arc saw cutting operations generated submicron particles and occasionally bimodal lognormal particle size distributions.

Particle size distributions listed by Dorrian and Bailey (1995) for operations involving uranium are summarized in Table 3.3. In view of the wide range of reported values for different uranium operations, sampling to characterize aerosol particle size distributions for individual work practices is recommended. 
Table 3.3 Sizes of uranium aerosols in work environments (Dorrian and Bailey, 1995)

\begin{tabular}{|c|c|c|c|}
\hline Type of workplace & Process and comments & $\operatorname{AMAD}(\mu \mathrm{m})$ & GSD \\
\hline Uranium mill & $\begin{array}{l}\text { Activities involving yellowcake } \\
\text { Drum loading } \\
\text { Powder sampling } \\
\text { Lid sealing } \\
\text { After } 2 \mathrm{~h} \text { inactivity }\end{array}$ & $\begin{array}{c}6-12 \\
12-20 \\
12-20 \\
3-6\end{array}$ & $\begin{array}{l}-- \\
-- \\
-- \\
--\end{array}$ \\
\hline Uranium mill & Product packaging & 13 & 4.1 \\
\hline Uranium mill & Drum filling & 9.1 & 3.2 \\
\hline Uranium mill & $\begin{array}{l}\text { Drum filling } \\
\text { Dust fall from hopper }\end{array}$ & $\begin{array}{l}5.8 \\
14\end{array}$ & $\begin{array}{l}2.7 \\
4.1\end{array}$ \\
\hline Uranium mill & $\begin{array}{l}\text { Activities involving yellowcake } \\
\text { Filtration } \\
\text { Packaging } \\
\text { Powder sampling } \\
\text { Packaging area, no activity }\end{array}$ & $\begin{array}{c}0.72 \\
4.5 \\
5.7 \\
0.5\end{array}$ & $\begin{array}{l}2.5 \\
2.3 \\
2.2 \\
2.8\end{array}$ \\
\hline Uranium mill & $\mathrm{U}, \mathrm{Th}$ & 7 & -- \\
\hline Uranium plant & $\begin{array}{l}\text { Uranyl fluoride production } \\
\text { Preparing U ore concentrates } \\
\text { Slag crushing } \\
\text { Annealing, inspection of U metal rods } \\
\text { Weighing } \mathrm{UF}_{4} / \mathrm{Mg} \text { pellets }\end{array}$ & $\begin{array}{c}1-9 \\
5 \\
4-8 \\
3.5 \\
2.5\end{array}$ & $\begin{array}{l}-- \\
-- \\
-- \\
--\end{array}$ \\
\hline Uranium plant & $\begin{array}{l}\text { Saw operation } \\
\text { Oxide burner operation }\end{array}$ & $\begin{array}{c}0.3 \\
0.12\end{array}$ & $\begin{array}{l}-- \\
--\end{array}$ \\
\hline Uranium plant & Burning of uranium cuttings & $\begin{array}{l}6.0,0.49 \\
\text { (bimodal) }\end{array}$ & -- \\
\hline Uranium plant & Metal fabrication & $>1$ & -- \\
\hline Uranium mines & $\begin{array}{l}\text { Stopes (underground) } \\
\text { Crusher-rock breaker (underground, } \\
\mathrm{U}, \mathrm{Th} \text { ) }\end{array}$ & $\begin{array}{l}5 \\
7\end{array}$ & $\begin{array}{l}-- \\
--\end{array}$ \\
\hline Uranium mine (open pit) & $\begin{array}{l}\text { Normal mining operations (long-lived } \\
\text { alpha emitters) }\end{array}$ & 11.7 & -- \\
\hline Copper-uranium-gold mine & $\begin{array}{l}\text { Stopes (underground, long-lived alpha } \\
\text { emitters) }\end{array}$ & 5 & \\
\hline Uranium mine & $\begin{array}{l}\text { Ore crushing, transport operations } \\
\text { (underground, U, Th, Ra) }\end{array}$ & 3 & -- \\
\hline Natural uranium workshop & -- & $3.5-6.0$ & -- \\
\hline Enrichment plant & -- & 8 & -- \\
\hline
\end{tabular}


Table 3.3 (continued)

\begin{tabular}{|c|c|c|c|}
\hline Type of workplace & Process and comments & AMAD $(\mu \mathrm{m})$ & GSD \\
\hline Fuel fabrication plant & $\begin{array}{l}\text { All generation conditions at various } \\
\text { work areas }\end{array}$ & 8.2 & $\begin{array}{ll}- \\
-\end{array}$ \\
\hline Fuel fabrication plant & Pellet press & 6.1 & 2.1 \\
\hline \multirow{7}{*}{ Fuel fabrication plant } & Fuel pellet loading & 5.2 & 1.8 \\
\hline & Grinding pellets & 5.7 & 2.1 \\
\hline & Sintering furnace area & 5.3 & 2.1 \\
\hline & Waste treatment area & 5.7 & 2.0 \\
\hline & Pellet press & 3.9 & 2.0 \\
\hline & Powder blending & 3.7 & 1.8 \\
\hline & Powder drum handling & 5.2 & 1.9 \\
\hline \multirow{2}{*}{ Fuel fabrication plant } & Pellet pressing & 8.8 & -- \\
\hline & Pellet turning & 7.1 & -- \\
\hline \multirow{9}{*}{$\begin{array}{l}\text { Mixed oxide reactor fuel } \\
\text { fabrication plant }\end{array}$} & Glove box operations $(\mathrm{Pu}, \mathrm{U})$ & & \\
\hline & Blending of mixed oxide & 2.5 & 1.5 \\
\hline & Jet milling & 1.6 & 1.6 \\
\hline & Dumping after jet milling & 2.3 & 1.7 \\
\hline & Blending after jet milling & 2.6 & 1.5 \\
\hline & Slug pressing & 3.1 & 1.5 \\
\hline & Grinding slugs & 2.3 & 1.7 \\
\hline & Fuel pellet pressing & 1.9 & 1.5 \\
\hline & Grinding of fuel pellets & 2.1 & 1.6 \\
\hline $\begin{array}{l}\text { Mixed oxide reactor fuel } \\
\text { fabrication plant }\end{array}$ & $\begin{array}{l}\text { Glove box operations, grinding }(\mathrm{Pu} \text {, } \\
\mathrm{U})\end{array}$ & 2.4 & 1.1 \\
\hline \multirow{2}{*}{$\begin{array}{l}\text { Demonstration fuel fabrication } \\
\text { plant (MOX) }\end{array}$} & Powder blending and mixing $(\mathrm{Pu}, \mathrm{U})$ & 1.9 & 1.6 \\
\hline & Grinding & 2.3 & 1.6 \\
\hline Spent fuel bays & $\begin{array}{l}\text { Transfer, cutting, storage and } \\
\text { shipment of fuel }(\mathrm{Pu}, \mathrm{U}, \mathrm{Sr}, \mathrm{Cs})\end{array}$ & 6.8 & 2.8 \\
\hline Monazite sand separation plant & Th, U & 1.4 & 2.0 \\
\hline Mineral sand reprocessing plant & Dry mill area $(\mathrm{Th}, \mathrm{U})$ & 3.2 & 2.8 \\
\hline \multirow[t]{3}{*}{ Mineral sand processing plants } & Dry separation plants $(\mathrm{Th}, \mathrm{U})$ & & \\
\hline & All particles & 9.0 & 5.3 \\
\hline & Particles $<20 \mu \mathrm{m}$ & 2.7 & 3.6 \\
\hline
\end{tabular}

\subsubsection{Sensitivity of Derived Secondary Reference Guidance Levels to AMAD}

The secondary reference guidance levels for occupational exposure to airborne uranium given in this report are largely determined by derived values $\mathrm{E}=$ committed effective dose per unit activity intake of uranium and $\mathrm{P}=$ peak concentration of uranium in the kidneys for idealized 
exposure scenarios. Action levels derived from primary reference radiological guidance levels alone (i.e., if primary reference chemical guidance levels were not also considered) vary inversely with $\mathrm{E}$, and action levels derived from primary reference chemical guidance alone vary inversely with $\mathrm{P}$. The values $\mathrm{E}$ and $\mathrm{P}$ depend on the size distribution of particles carrying the airborne uranium, which is expressed in this report in units of AMAD. An AMAD of $5 \mu \mathrm{m}$ is used to derive default action levels. This appears to be a reasonable central estimate for uranium aerosols based on measurements in a variety of uranium facilities (Table 3.3), but values for individual sites or work stations vary from about $0.1 \mu \mathrm{m}$ to well over $10 \mu \mathrm{m}$.

Figure 3.5 summarizes results of an analysis of the sensitivity of $E$ and $P$ to variation in AMAD within the range of particle sizes listed in Table 3.3, for uranium of Type F, Type M, or Type S. Results for particle sizes $>10 \mu \mathrm{m}$ (not shown) are continuations of the indicated trends for sizes from $5 \mu \mathrm{m}$ to $10 \mu \mathrm{m}$. All of the curves in the figure were based on inhalation of ${ }^{234} \mathrm{U}$ but would be virtually identical if based on ${ }^{235} \mathrm{U},{ }^{238} \mathrm{U}$, or a mixture of ${ }^{234} \mathrm{U},{ }^{235} \mathrm{U}$, and ${ }^{238} \mathrm{U}$. The committed effective dose $\mathrm{E}$ is based on acute intake. Because the peak kidney concentration $\mathrm{P}$ can vary strongly from one exposure pattern to another, the sensitivity of $\mathrm{P}$ to AMAD was examined both for acute and chronic exposure scenarios. The curves labeled P-acute and P-chronic represent the peak concentration of uranium in the kidneys following acute intake and during continuous intake at a constant rate, respectively. Each curve in Figure 3.5 is normalized to the value 1.0 at $5 \mu \mathrm{m}$ AMAD as follows. A committed effective dose coefficient $\mathrm{E}$ derived for a given particle size is divided by the inhalation dose coefficient for ${ }^{234} \mathrm{U}$ (Table 3.16) for the same absorption type and particle size $5 \mu \mathrm{m}$ AMAD. Values for P-acute are based on acute intake of $1 \mu \mathrm{g} \mathrm{U}$ and are normalized by dividing by the value of P-acute derived for particle size $5 \mu \mathrm{m}$ AMAD. Values for P-chronic are based on continuous intake at the rate $1 \mu \mathrm{g} \mathrm{U} / \mathrm{d}$ and are normalized by dividing by the value of P-chronic derived for particle size $5 \mu \mathrm{m}$ AMAD.

For inhalation of uranium of Type F, the normalized curves for E, P-acute, and P-chronic are virtually identical. For example, a change in the AMAD that leads to a $15 \%$ increase in E will also lead to a $15 \%$ increase in $\mathrm{P}$-acute or $\mathrm{P}$-chronic. The values $\mathrm{E}, \mathrm{P}$-acute, and $\mathrm{P}$-chronic are only moderately sensitive to AMAD, varying by $<35 \%$ from values derived from the default AMAD of $5 \mu \mathrm{m}$ as the AMAD ranges from 0.1 to $20 \mu \mathrm{m}$. The relatively small variation of these values with AMAD indicates that action levels based on the default AMAD should be appropriate for application to exposures to uranium aerosols with sizes in the range $0.1-20 \mu \mathrm{m}$.

P-acute was also found to be only moderately sensitive to AMAD for inhalation of uranium aerosols of Type $\mathrm{M}$, varying by about $35 \%$ from the value of P-acute at $5 \mu \mathrm{m}$ AMAD as the particle size varies in the range 0.1-20 $\mu \mathrm{m}$ AMAD. P-acute was found to be somewhat more sensitive to AMAD for Type S material, varying by about $65 \%$ from the value of P-acute at $5 \mu \mathrm{m}$ AMAD as the particle size varies in the range 0.1-20 $\mu \mathrm{m}$ AMAD. For both Type $\mathrm{M}$ and Type $\mathrm{S}$ material, however, the value of $\mathrm{P}$-acute at $5 \mu \mathrm{m}$ AMAD is near the peak value for particle sizes in the range $0.1-20 \mu \mathrm{m}$ AMAD. Hence, it seems reasonable to apply action levels based on the default AMAD in virtually any situation where P-acute is the limiting consideration. 

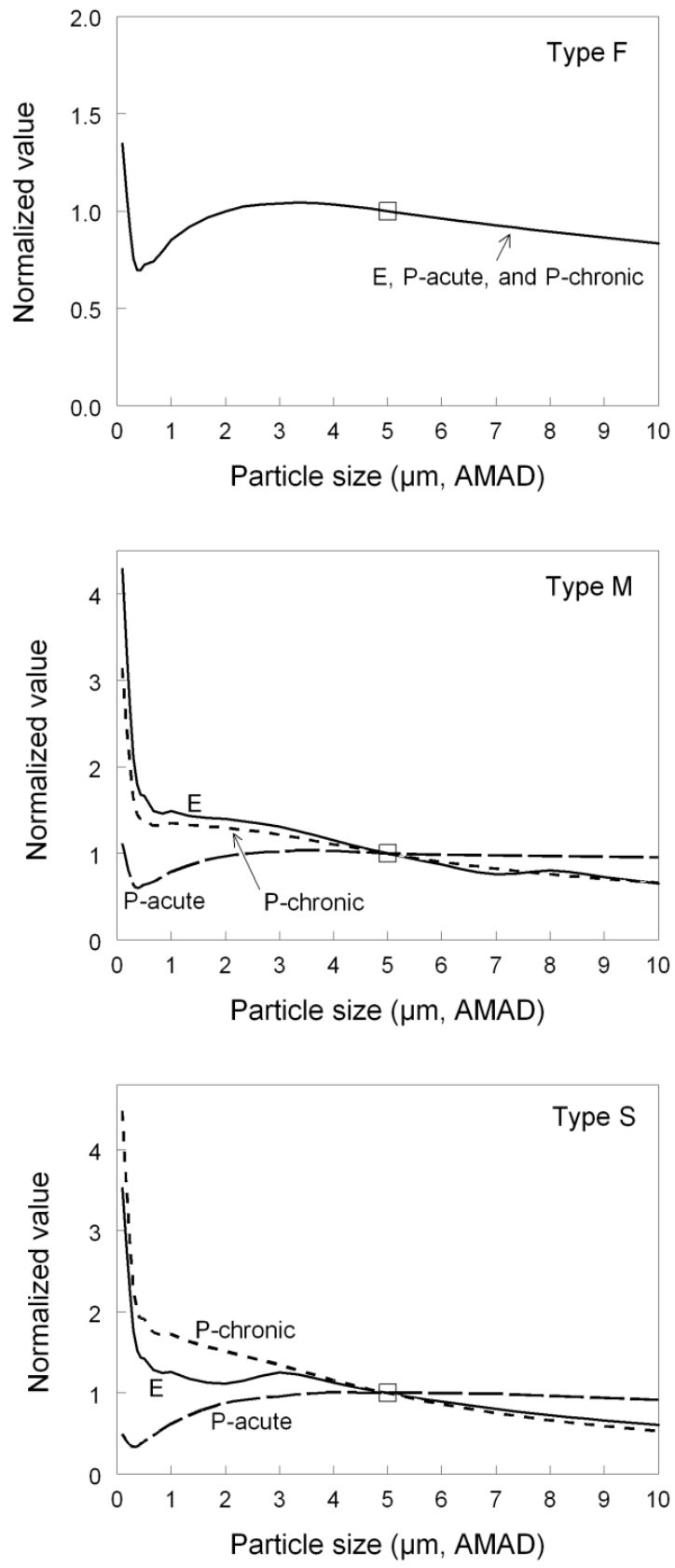

Figure 3.5 For inhaled ${ }^{234} \mathrm{U}$, sensitivity of effective dose coefficient (E) and peak kidney concentration (P-acute and P-chronic for acute and chronic intake, respectively) to particle size. For each absorption type the curves for E, P-acute, and P-chronic are each normalized to 1.0 for inhaled particle size $5 \mu \mathrm{m}$ (represented by a square).

For inhalation of uranium of Type $\mathrm{M}$ or Type $\mathrm{S}$, the values $\mathrm{E}$ and $\mathrm{P}$-chronic vary nearly in parallel and are more sensitive to AMAD than in the case of inhalation of Type F material. $\mathrm{E}$ and P-chronic generally increase with decreasing particle size. The steepest climb occurs as the AMAD decreases from $0.5 \mu \mathrm{m}$ to $0.1 \mu \mathrm{m}$, where values reach about 3-4.5 times the values based on the default particle size. The relatively high sensitivity of $\mathrm{E}$ and $\mathrm{P}$-chronic to changes in the 
AMAD below $0.5 \mu \mathrm{m}$ results from HRTM predictions that fractional deposition of inhaled activity in deep lungs increases sharply with decreasing particle size for submicron particles. According to the HRTM, a substantial portion of material of Type M or Type S deposited in the $\mathrm{AI}$ is retained for an extended period. Derived lung doses for long-lived uranium isotopes are nearly proportional to the assumed residence time in AI. Also, fractional absorption of uranium to blood and hence uptake by the kidneys increases roughly in proportion to the fraction of inhaled material retained in the AI region for an extended period, due essentially to slow net mechanical clearance from AI compared with the competing rate of absorption to blood.

As indicated in Table 3.3, sizes of airborne uranium particles in the workplace typically are in the range 1-20 $\mu \mathrm{m}$ AMAD, but certain tasks such as high temperature and arc saw cutting operations may involve particle sizes $<1 \mu \mathrm{m}$ AMAD. For workers involved in operations known or suspected to produce a relatively high quantity of submicron particles, it is prudent to take special measures to ensure that the primary reference chemical and radiological guidance levels (see Sections 1 and 2) are not exceeded. Examples of special measures that may be taken include derivation of air concentration guidelines specific to measured particle sizes based on the methods described in Section 5, limiting work time in the area, or increasing urinary uranium measurements and chest counts for frequent comparison with action levels in Table 1.2.

\subsubsection{Comparison of AMAD and MMAD}

The mass median aerodynamic diameter (MMAD) is defined as the aerodynamic diameter of an aerosol particle whose mass is the median for the aerosol. The MMAD is equal to the AMAD if the activity per unit mass is constant among all particles in the aerosol, which is not always the case. For example, Kotrappa et al. 1979 found that radioactivity per unit mass or volume increased with decreasing particle size in airborne uranium ore dust in a uranium crusher house. The study was carried out on particles with area diameter in the range $0.6-3 \mu \mathrm{m}$. The area diameter of a particle is the diameter of a circle having a cross sectional area equivalent to that of the particle.

Kotrappa and coworkers (1979) proposed that the AMAD of ore dust can be estimated from the MMAD using the equation:

$$
A M A D=M M A D e^{-0.955 \times \ln ^{2}\left(\sigma_{g}\right)}
$$

where, $\ln ^{2}$ is the square of the natural logarithm and $\sigma_{\mathrm{g}}$ is the geometric standard deviation (GSD). A typographical error in the equation given in the paper by Kotrappa and coworkers has been corrected.

Equation 3.1 implies that the AMAD is less than the MMAD for ore dust. For example, an MMAD of $5.0 \mu \mathrm{m}$ with GSD of 2.1 corresponds to an AMAD of $3.0 \mu \mathrm{m}$; an MMAD of $2 \mu \mathrm{m}$ with GSD of 1.7 corresponds to an AMAD of $1.5 \mu \mathrm{m}$; and an MMAD of $0.7 \mu \mathrm{m}$ with GSD of 2.0 corresponds to an AMAD of $0.44 \mu \mathrm{m}$.

Equation 3.1 does not hold for uranium aerosols in general. For example, Bhanti et al. 1986 found that the concentration of uranium in monazite sand varies with the cube of the diameter of 
airborne particles in the size range $0.6-2 \mu \mathrm{m}$ (area diameter). This indicates that activity is roughly proportional to mass and hence that MMAD is approximately the same as AMAD in this case. Monleau et al. 2006 measured MMAD and AMAD for aerosols generated from $\mathrm{UO}_{2}$ and $\mathrm{UO}_{4}$ powders found in work areas of uranium fuel cycle facilities. For $\mathrm{UO}_{2}$ aerosols the AMAD was $2.53 \mu \mathrm{m}$ with GSD of 1.93, and the MMAD was $1.8 \mu \mathrm{m}$ with GSD 1.66. For $\mathrm{UO}_{4}$ aerosols the AMAD was $2.34 \mu \mathrm{m}$ with GSD 2.01, and the MMAD was $1.31 \mu \mathrm{m}$ with GSD 1.70. Based on the measured MMADs and associated GSDs, Equation 3.1 would predict an AMAD of 1.41 $\mu \mathrm{m}$ for $\mathrm{UO}_{2}$ aerosols compared with the measured value of $2.53 \mu \mathrm{m}$, and an AMAD of 1.0 for $\mathrm{UO}_{4}$ aerosols compared with the measured value of $2.34 \mu \mathrm{m}$.

Ideally, the MMAD of a uranium aerosol would be used to estimate total and regional deposition in the respiratory tract if the goal is to estimate the time-dependent mass concentration of uranium in the kidneys, and the AMAD would be used to estimate deposition if the goal is to estimate radiation doses to tissues. Based on reported relations of MMAD and AMAD for uranium aerosols, however, differences between the MMAD and AMAD may not to be of much practical consequence with regard to interpretation of uranium monitoring data. For example, for inhaled $\mathrm{UO}_{2}$ of Type $\mathrm{S}$, the derived effective dose per unit intake based on an assumed AMAD of $1.8 \mu \mathrm{m}$ (the MMAD measured by Monleau and coworkers for $\mathrm{UO}_{2}$ aerosols) differs by only $14 \%$ from the value based on the measured AMAD of $2.53 \mu \mathrm{m}$. For inhaled $\mathrm{UO}_{4}$ of Type $\mathrm{F}$, the derived peak concentration of uranium in the kidneys per unit intake based on an assumed MMAD of $2.34 \mu \mathrm{m}$ (the AMAD measured by Monleau and coworkers for $\mathrm{UO}_{4}$ aerosols) differs by only $13 \%$ from the value based on the measured MMAD of $1.31 \mu \mathrm{m}$ (this applies to both acute and chronic intake). For moderately soluble (Type M) uranium ore dust inhaled as fine particles (say, size $0.70 \mu \mathrm{m}$ MMAD with GSD =2.0), the derived peak concentration of uranium in the kidneys per unit intake based on the MMAD differs by only $12 \%$ from the value based on an assumed MMAD of $0.44 \mu \mathrm{m}$ [the AMAD derived from Equation 3.1] (this applies to both acute and chronic intake). For the same case of inhaled uranium ore dust, the effective dose per unit intake derived from an assumed AMAD of $0.70 \mu \mathrm{m}$ (the MMAD) differs by only $12 \%$ from the value based on an AMAD of $0.44 \mu \mathrm{m}$.

To summarize, the MMAD of a uranium aerosol ideally would be used as model input to derive the peak mass concentration of uranium in the kidneys, and the AMAD ideally would be used as input to estimate radiation doses to tissues. In practice, any predictive error resulting from equating MMAD and AMAD is likely to be negligible compared with other sources of error including uncertainty and variability in the biokinetics of well characterized forms of uranium and case-specific uncertainties such as the form of uranium inhaled, the average concentration of uranium in air in the work area, intake by a given worker in the area, and the average concentration of uranium in urine in a given worker. Thus, if the MMAD of an aerosol is known and the AMAD is not, it is reasonable to assume that the AMAD is equal to the MMAD. If the AMAD is known and the MMAD is not, it is reasonable to assume that the MMAD is equal to the AMAD. 


\subsection{Gastrointestinal Kinetics}

\subsubsection{ICRP Models of Gastrointestinal Transit}

The biokinetic and dosimetric model of the gastrointestinal (GI) tract used to derive dose coefficients tabulated in current ICRP documents is based on a GI transit model developed in the mid-1960s. The model (Figure 3.6) was first used by the ICRP in Publication 30, Limits for Intakes of Radionuclides by Workers (ICRP 1979), and is referred to here as the Pub30 model.

The ICRP recently adopted a more sophisticated model of the behavior of radionuclides in the entire alimentary tract. The updated model, referred to as the Human Alimentary Tract Model (HATM), will replace the Pub30 model in upcoming ICRP reports.

With regard to calculation of effective dose or organ doses from intake of uranium, it makes little difference whether the Pub30 model or HATM is applied as long as the same gut uptake fraction is applied in both cases. For use in a bioassay program, the main difference between the two models is that the HATM predicts a slightly longer transit time of material through the alimentary tract and thus a slightly lower rate of fecal excretion of activity in the first few days after intake. This makes a modest difference in back calculation of intake based on fecal data for early times after intake. The HATM is applied in the present report. Both the HATM and the Pub30 model, which is still used in many dose and bioassay codes, are summarized below.

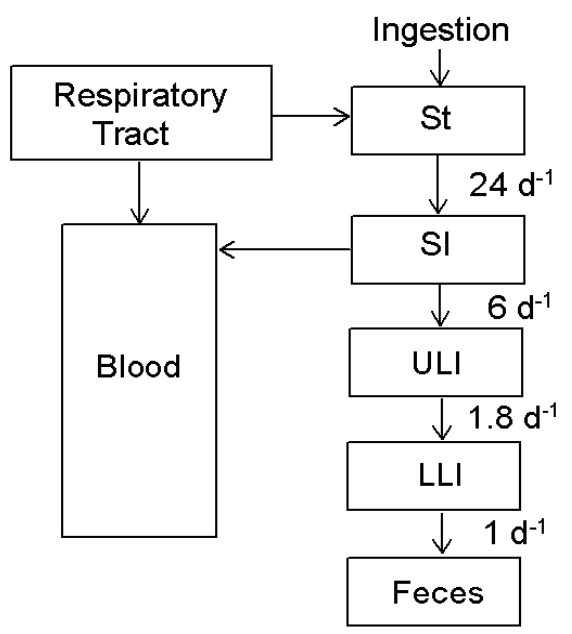

Figure 3.6 Structure of the gastrointestinal tract model used by the ICRP since the late 1970s (ICRP 1979).

\subsubsection{Pub30 Model of the GI Tract}

The Pub30 model divides the GI tract into four segments or compartments: stomach (St), small intestine (SI), upper large intestine (ULI), and lower large intestine (LLI), and depicts first-order transfer of material from one segment to the next. Material is assumed to transfer from St to SI at the fractional rate of $24 \mathrm{~d}^{-1}$, from SI to ULI at $6 \mathrm{~d}^{-1}$, from ULI to LLI at $1.8 \mathrm{~d}^{-1}$, and from LLI to Feces at $1 \mathrm{~d}^{-1}$. 
Absorption of ingested activity to blood is assumed to occur in SI and is described by an element-specific or, in some cases, a compound-specific " $f_{1}$ value" representing fractional absorption of the stable element to blood. For dosimetric calculations each segment of the tract is represented as an idealized geometric figure. Estimates of dose to tissues of the GI tract from non-penetrating radiations emitted in the contents of the tract are based on simplistic assumptions. For beta and alpha emitters the dose to the walls of the GI tract from activity in the GI contents is taken as $100 \%$ and $1 \%$, respectively, of the dose at the surface of the contents. This is in addition to the dose to the walls of the GI tract from absorbed activity, which is often the dominant source of dose to the walls of the tract, particularly from long-lived radionuclides.

\subsubsection{ICRP's Updated Human Alimentary Tract Model}

The structure of the HATM is shown in Figure 3.7. The compartments and paths of movement represent the following processes: entry of a radionuclide into the oral cavity by ingestion or into the esophagus after mechanical clearance from the respiratory tract; sequential transfer through the lumen of the oral cavity, esophagus, stomach, small intestine, and segments of the colon, followed by emptying in feces; radionuclide deposition and retention on or between the teeth and return to the oral cavity; deposition and retention in the oral mucosa or walls of the stomach or intestines; transfer from the oral mucosa or walls of the stomach or intestines back into the lumenal contents or into blood (absorption); and transfer from secretory organs or blood into the contents of segments of the tract.

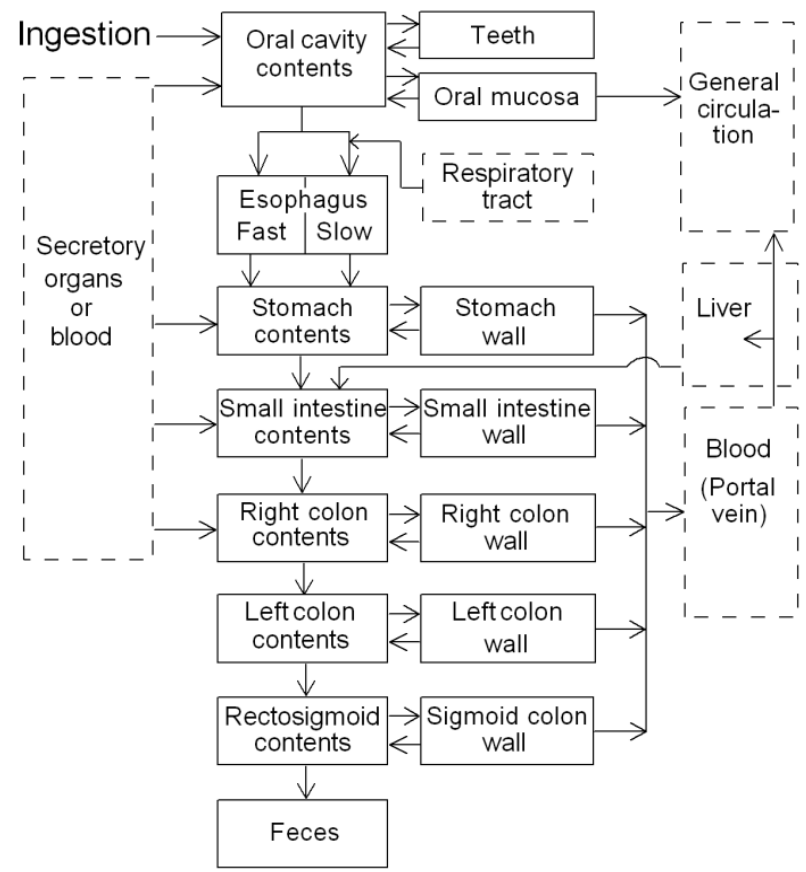

Figure 3.7 Structure of the HATM. The dashed boxes are not part of the HATM but are included in the schematic to show connections between the HATM and respiratory and systemic models.

Entry into the alimentary tract by ingestion or transfer from the respiratory tract and sequential transfer through the lumen of the tract are regarded as generic processes in that the rates are 
assumed to be independent of the radionuclide. The other processes addressed by the HATM are assumed to occur at element-specific rates. For example, element-specific parameter values are required to describe uptake and retention in the walls of the alimentary tract. An elementspecific process is addressed in HATM applications only if information is available to assign a non-zero transfer rate to that process. For most elements, specific information on behavior in the alimentary tract is limited to measurements of fractional absorption to blood.

Separate transit times are provided for transfer of ingested solids, liquids, and total diet through the mouth and esophagus and for transit of non-caloric liquids, caloric liquids, solids, and total diet through the stomach. The material-specific values were developed for application to special cases. Transit values for total diet are intended for standard applications of the HATM.

For purposes of calculating absorbed fractions for short-range radiations originating in the contents of the alimentary tract, the segments of the tract are represented as a set of idealized geometric figures and the contents as a homogenous material. For example, the stomach is treated as a sphere and the esophagus and intestines as right circular cylinders.

The HATM and Pub30 model yield similar tissue dose estimates for most radionuclides, but in some cases the HATM will yield substantially different doses to walls of the alimentary tract for one or both of the following reasons:

- Retention of radionuclides in the walls of the tract can be specified in the HATM when information is available. This feature can result in substantial increases in the estimated dose to the walls.

- The location of sensitive cells of different regions of the tract is modeled explicitly in the HATM. The targets for all effects are taken to be the epithelial stem cells, which are known to be removed by some distance from the lumen of the tract. For some alpha and beta emitters, this change from the Pub30 model results in substantially reduced dose estimates because alpha emissions and low-energy beta emissions originating in the contents of the tract do not penetrate to the depth at which the sensitive cells are estimated to reside.

\subsubsection{Gastrointestinal Absorption of Uranium}

Uranium may be absorbed from the alimentary tract to blood after oral intake or after swallowing of inhaled activity that has been escalated up the respiratory airways to the pharynx. Fractional absorption of uranium from the alimentary tract after escalation from the respiratory tract cannot be determined directly due to simultaneous absorption of uranium from the respiratory tract. Estimated fractional absorption of uranium after oral intake ranges from less than 0.001 to about 0.06 for individual subjects (Leggett and Harrison 1995; Harrison et al. 2001). Central values estimated in controlled studies on humans range from about 0.01 to about 0.025 . Environmental studies yield central estimates in the range 0.003-0.03. Data from studies on laboratory animals indicate that fractional uptake of forms of uranium commonly encountered in the workplace depends strongly on the chemical form ingested. Absorption appears to be greatest for uranium ingested as $\mathrm{UO}_{2}\left(\mathrm{NO}_{3}\right)_{2} \cdot 6 \mathrm{H}_{2} \mathrm{O}, \mathrm{UO}_{2} \mathrm{~F}_{2}$, or $\mathrm{Na}_{2} \mathrm{U}_{2} \mathrm{O}_{7}$, roughly half as great for $\mathrm{UO}_{4}$ or $\mathrm{UO}_{3}$, and 1-2 orders of magnitude lower for $\mathrm{UCl}_{4}, \mathrm{U}_{3} \mathrm{O}_{8}, \mathrm{UO}_{2}$, and $\mathrm{UF}_{4}$ (Leggett and Harrison 1995). 
In current documents of the ICRP (1994b, 1995a, 1995b), fractional uptake from the alimentary tract to blood is assumed to be 0.02 for relatively soluble forms of uranium including uranium in food or drink and 0.002 for relatively insoluble forms of uranium. For activity that is swallowed after escalation from the respiratory tract, the value 0.02 is applied to uranium inhaled as Type $\mathrm{F}$ or Type M material, and 0.002 is applied to uranium inhaled as Type $\mathrm{S}$ material.

As is the case for parameter values describing dissolution and absorption in the respiratory tract, the ICRP's default values for fractional absorption of uranium from the gastrointestinal tract may be replaced by material-specific values whenever there is supporting information or suggestive evidence that the default values are not sufficiently cautious. This is illustrated in an earlier discussion of inhaled uranyl carbonate complexes in Section 3.1.2.

\subsection{Biokinetics of Uranium that Reaches Blood}

The ICRP's current systemic biokinetic model for uranium was adopted in ICRP Publication 69 (1995a). The model structure is shown in Figure 3.8. This is a generic model structure applied by the ICRP to several elements that tend to follow the movement of calcium in bone (Leggett 1992). Uranium is not a physiological analogue of calcium in most respects, but the uranyl ion follows the movement of calcium in bone sufficiently closely that the structure of the calcium model is applicable to uranium (Leggett 1994). There is evidence that $\mathrm{UO}_{2}{ }^{++}$exchanges with $\mathrm{Ca}^{++}$at the surfaces of bone mineral crystals, although $\mathrm{UO}_{2}{ }^{++}$apparently does not participate in crystal formation or enter existing crystals. The gross distribution of uranium in the skeleton is similar to that of calcium at early times after uptake to blood. Uranium is initially present on all bone surfaces but is most highly concentrated in areas of growth. Perhaps depending on the microscopic structure of the bone of each species, uranium on bone surfaces may gradually diffuse into bone volume. As is the case for calcium, a substantial portion of uranium deposited in bone apparently is lost to blood plasma by processes that occur more rapidly than bone resorption.

Parameter values for uranium in a reference adult are given in Table 3.4. Some of these values are generic for the so-called "bone-volume-seeking" elements. For example, values describing removal from non-exchangeable bone volume compartments are estimated in terms of bone remodeling rates and therefore are independent of the element. Most of the transfer coefficients in the model are element specific. Uranium-specific parameter values given in Table 3.4 were based mainly on the following sources of information: measurements of uranium in blood and excreta of several human subjects who were intravenously injected with uranium; postmortem measurements of uranium in tissues of some of those subjects; postmortem measurements of uranium in tissues of occupationally and environmentally exposed subjects; data on baboons, dogs, or smaller laboratory animals exposed to uranium for experimental purposes; and consideration of the physiological processes thought to determine retention and translocation of uranium in the body (Leggett 1994; ICRP 1995a). The methods of selection of the parameter values of the ICRP's systemic model for uranium are described by Leggett (1994). 


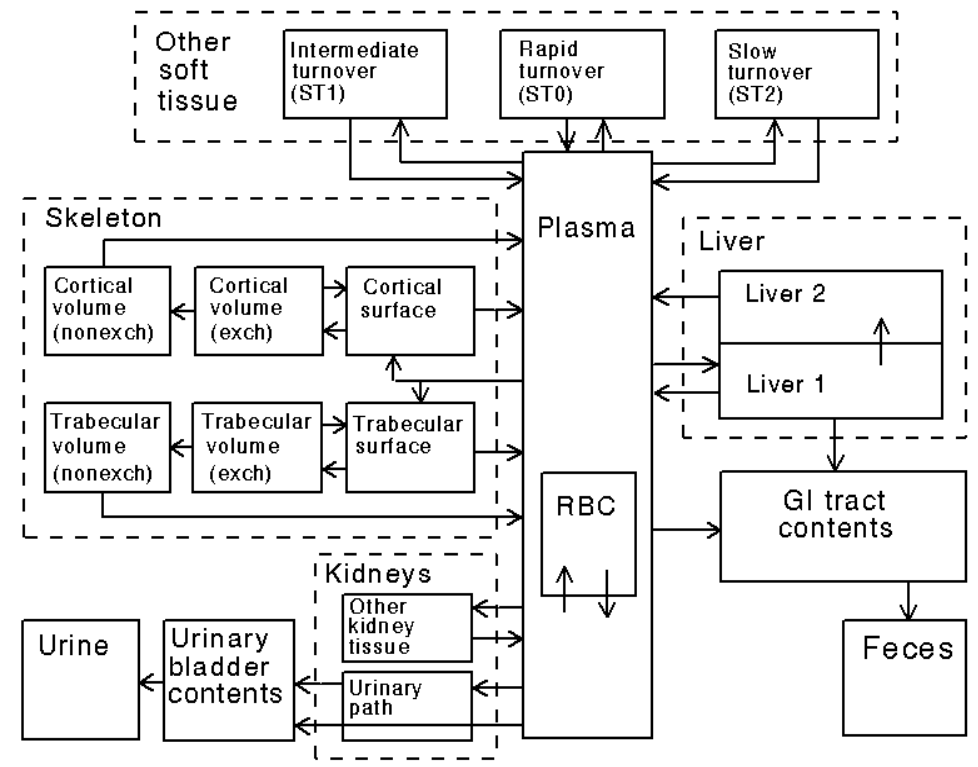

Figure 3.8. The ICRP's model structure for uranium (after ICRP Publication 69 1995a); exch $=$ exchangeable; nonexch $=$ nonexchangeable . 
Table 3.4 Transfer coefficients in ICRP's model for systemic uranium (ICRP 1995a)

\begin{tabular}{|c|c|}
\hline Path & $\begin{array}{c}\text { Transfer coefficient } \\
\left(d^{-1}\right)\end{array}$ \\
\hline $\begin{array}{l}\text { From plasma to: } \\
\text { ST0 } \\
\text { RBC } \\
\text { Urinary bladder contents } \\
\text { Kidney } 1 \\
\text { Kidney } 2 \\
\text { Upper large intestine contents } \\
\text { Liver 1 } \\
\text { ST1 } \\
\text { ST2 } \\
\text { Trabecular bone surfaces } \\
\text { Cortical bone surfaces }\end{array}$ & $\begin{array}{l}1.050 \times 10^{1} \\
2.450 \times 10^{-1} \\
1.543 \times 10^{1} \\
2.940 \times 10^{0} \\
1.220 \times 10^{-2} \\
1.220 \times 10^{-1} \\
3.670 \times 10^{-1} \\
1.630 \times 10^{0} \\
7.350 \times 10^{-2} \\
2.040 \times 10^{0} \\
1.630 \times 10^{0}\end{array}$ \\
\hline $\begin{array}{l}\text { To plasma from: } \\
\text { ST0 } \\
\text { RBC } \\
\text { Kidney } 2 \\
\text { Liver 1 } \\
\text { Liver } 2 \\
\text { ST1 } \\
\text { ST2 } \\
\text { Bone surfaces }{ }^{a} \\
\text { Nonexch. trabecular bone volume } \\
\text { Nonexch. cortical bone volume }\end{array}$ & $\begin{array}{l}8.320 \times 10^{0} \\
3.470 \times 10^{-1} \\
3.800 \times 10^{-4} \\
9.200 \times 10^{-2} \\
1.900 \times 10^{-4} \\
3.470 \times 10^{-2} \\
1.900 \times 10^{-5} \\
6.930 \times 10^{-2} \\
4.930 \times 10^{-4} \\
8.210 \times 10^{-5}\end{array}$ \\
\hline From Kidney 1 to urinary bladder contents & $9.900 \times 10^{-2}$ \\
\hline From Liver 1 to Liver 2 & $6.930 \times 10^{-3}$ \\
\hline From bone surfaces to exchangeable bone volume ${ }^{a}$ & $6.930 \times 10^{-2}$ \\
\hline From exchangeable bone volume to bone surfaces ${ }^{a}$ & $1.730 \times 10^{-2}$ \\
\hline $\begin{array}{l}\text { From exchangeable bone volume to } \\
\text { nonexchangeable volume }\end{array}$ & $5.780 \times 10^{-3}$ \\
\hline
\end{tabular}

${ }^{a}$ Applies both to trabecular and cortical bone compartments. 


\subsection{Model Predictions of Retention and Excretion of Uranium Following Acute Inhalation}

Because it is not feasible to derive action levels for each of a comprehensive set of exposure patterns that may arise in the workplace, derived values are based on two idealized patterns of exposure: (1) acute intake, and (2) continuous intake at a constant rate. The second pattern does not actually occur in the workplace but for computational convenience is used as a surrogate for chronic occupational intake for purposes of projecting accumulation of activity in tissues and radiation doses and evaluating bioassay data. Section 4 compares predictions of retention and excretion of uranium based on continuous exposure with predictions based on more complex patterns of exposure that might occur in the workplace. The tables and figures that follow in the present section give model predictions, based on either acute intake or continuous intake at a constant rate, of quantities such as urinary and fecal excretion rates and retention in the lungs that may be useful for interpreting monitoring data or bioassay data for uranium.

Model predictions of retention and excretion of long-lived uranium isotopes as a function of time following acute uptake of uranium into blood at time zero are given in Table 3.5. Predictions of retention and excretion during continuous uptake to blood at a constant rate are given in Table 3.6. Table 3.5 might be used to evaluate situations in which short-term uptake to blood is suspected (e.g., a puncture wound case involving a relatively soluble form of uranium). Table 3.5 might also be used to estimate urinary and fecal excretion rates and total systemic retention of uranium in any case where the input to blood occurs over an extended period, provided the rate of input to blood can be estimated as a function of time.

Model predictions of retention and excretion of long-lived uranium isotopes as a function of time following acute inhalation of relatively soluble (Type F), moderately soluble (Type M), and relatively insoluble (Type $\mathrm{S}$ ) forms by a reference worker are given in Tables 3.7-3.9, respectively. Model predictions of retention and excretion of long-lived uranium isotopes as a function of time following the start of continuous exposure (24 hours a day, 7 days a week) of relatively soluble (Type F), moderately soluble (Type M), and relatively insoluble (Type S) forms by a reference worker are given in Tables 3.10-3.12, respectively. A gastrointestinal uptake fraction of 0.02 was applied to Type $\mathrm{F}$ and Type $\mathrm{M}$, and 0.002 was applied to Type S.

Figures 3.9-3.11 address the concentration of uranium in the kidneys as a function of time after acute intake of uranium or during chronic exposure to uranium. The mass of the kidneys is assumed to be $310 \mathrm{~g}$, the value given in ICRP Publication 89 (2002b) for a reference adult male. Figure 3.9 addresses direct input of uranium to blood either acutely, as might occur in the case of a uranium-contaminated puncture wound, or chronically, as might occur in the case of a wound in which a small piece of uranium metal is left embedded in muscle tissue. Figure 3.10 shows model predictions of the concentration of uranium in the kidneys as a function of time after acute inhalation of $1 \mu \mathrm{g}$ of relatively soluble (Type F), moderately soluble (Type M), or relatively insoluble (Type $\mathrm{S}$ ) uranium of particle size $5 \mu \mathrm{m}$ AMAD. Figure 3.11 shows model predictions of the concentration of uranium in the kidneys as a function of time after start of continuous inhalation of these three generic forms of uranium at the rate $1 \mu \mathrm{g} \mathrm{U} / \mathrm{d}$. It can be shown that the uranium concentration in the kidney converges to essentially the same value over an extended period regardless of the pattern of intake within any one-week or one-month period, as long as the total weekly or monthly intake is constant. Model predictions of the mass concentration of 
uranium in the kidneys gradually approach $0.003 \mu \mathrm{g} \mathrm{U} / \mathrm{g}$ kidney for inhalation of Type $\mathrm{F}$ material, $0.00075 \mu \mathrm{g} \mathrm{U} / \mathrm{g}$ kidney for inhalation of Type M material, and $0.000078 \mu \mathrm{g} \mathrm{U} / \mathrm{g}$ kidney for inhalation of Type $\mathrm{S}$ material.

Table 3.5 Model predictions of retention and excretion (fraction of intake) of uranium following acute input of uranium into blood

\begin{tabular}{|c|c|c|c|c|c|c|}
\hline \multirow{2}{*}{$\begin{array}{c}\text { Day } \\
\text { after } \\
\text { intake }^{a}\end{array}$} & \multicolumn{2}{|c|}{ Urine } & \multicolumn{2}{|c|}{ Feces } & \multirow{2}{*}{$\begin{array}{l}\text { Retained } \\
\text { in kidneys }\end{array}$} & \multirow{2}{*}{$\begin{array}{c}\text { Retained } \\
\text { in total } \\
\text { body }\end{array}$} \\
\hline & $24 \mathrm{~h}$ & Cumulative & $24 \mathrm{~h}$ & Cumulative & & \\
\hline 1 & $6.4 \mathrm{E}-01$ & $6.4 \mathrm{E}-01$ & $1.3 \mathrm{E}-03$ & $1.3 \mathrm{E}-03$ & $1.1 \mathrm{E}-01$ & $3.5 \mathrm{E}-01$ \\
\hline 2 & $2.3 \mathrm{E}-02$ & $6.7 \mathrm{E}-01$ & $2.3 \mathrm{E}-03$ & $3.7 \mathrm{E}-03$ & $1.0 \mathrm{E}-01$ & $3.3 \mathrm{E}-01$ \\
\hline 3 & $1.8 \mathrm{E}-02$ & $6.8 \mathrm{E}-01$ & $1.1 \mathrm{E}-03$ & 4.7E-03 & $9.5 \mathrm{E}-02$ & $3.1 \mathrm{E}-01$ \\
\hline 4 & $1.6 \mathrm{E}-02$ & 7.0E-01 & $3.5 \mathrm{E}-04$ & $5.1 \mathrm{E}-03$ & 8.7E-02 & 2.9E-01 \\
\hline 5 & $1.5 \mathrm{E}-02$ & 7.2E-01 & $1.3 \mathrm{E}-04$ & $5.2 \mathrm{E}-03$ & 8.0E-02 & $2.8 \mathrm{E}-01$ \\
\hline 6 & $1.3 \mathrm{E}-02$ & 7.3E-01 & $6.8 \mathrm{E}-05$ & $5.3 \mathrm{E}-03$ & 7.4E-02 & 2.7E-01 \\
\hline 7 & $1.2 \mathrm{E}-02$ & 7.4E-01 & $5.1 \mathrm{E}-05$ & $5.3 \mathrm{E}-03$ & $6.8 \mathrm{E}-02$ & $2.5 \mathrm{E}-01$ \\
\hline 8 & $1.1 \mathrm{E}-02$ & 7.5E-01 & 4.4E-05 & $5.4 \mathrm{E}-03$ & $6.2 \mathrm{E}-02$ & 2.4E-01 \\
\hline 9 & $1.0 \mathrm{E}-02$ & 7.6E-01 & 4.0E-05 & $5.4 \mathrm{E}-03$ & $5.7 \mathrm{E}-02$ & 2.3E-01 \\
\hline 10 & $9.4 \mathrm{E}-03$ & 7.7E-01 & $3.6 \mathrm{E}-05$ & $5.4 \mathrm{E}-03$ & $5.3 \mathrm{E}-02$ & 2.2E-01 \\
\hline 15 & $6.1 \mathrm{E}-03$ & $8.1 \mathrm{E}-01$ & $2.3 \mathrm{E}-05$ & $5.6 \mathrm{E}-03$ & $3.5 \mathrm{E}-02$ & $1.8 \mathrm{E}-01$ \\
\hline 20 & 4.2E-03 & $8.4 \mathrm{E}-01$ & $1.7 \mathrm{E}-05$ & $5.7 \mathrm{E}-03$ & 2.3E-02 & $1.6 \mathrm{E}-01$ \\
\hline 30 & $2.3 \mathrm{E}-03$ & 8.7E-01 & $1.1 \mathrm{E}-05$ & $5.8 \mathrm{E}-03$ & $1.1 \mathrm{E}-02$ & $1.3 \mathrm{E}-01$ \\
\hline 40 & $1.5 \mathrm{E}-03$ & $8.9 \mathrm{E}-01$ & 7.9E-06 & $5.9 \mathrm{E}-03$ & 5.7E-03 & $1.1 \mathrm{E}-01$ \\
\hline 50 & $1.0 \mathrm{E}-03$ & $9.0 \mathrm{E}-01$ & $6.1 \mathrm{E}-06$ & $6.0 \mathrm{E}-03$ & $3.5 \mathrm{E}-03$ & 9.7E-02 \\
\hline 60 & 7.9E-04 & $9.1 \mathrm{E}-01$ & 4.9E-06 & $6.0 \mathrm{E}-03$ & $2.5 \mathrm{E}-03$ & 8.7E-02 \\
\hline 70 & $6.2 \mathrm{E}-04$ & $9.1 \mathrm{E}-01$ & $4.0 \mathrm{E}-06$ & $6.1 \mathrm{E}-03$ & $1.9 \mathrm{E}-03$ & 8.0E-02 \\
\hline 80 & $5.0 \mathrm{E}-04$ & $9.2 \mathrm{E}-01$ & $3.3 \mathrm{E}-06$ & $6.1 \mathrm{E}-03$ & $1.6 \mathrm{E}-03$ & 7.5E-02 \\
\hline 90 & 4.2E-04 & $9.2 \mathrm{E}-01$ & $2.7 \mathrm{E}-06$ & $6.1 \mathrm{E}-03$ & $1.4 \mathrm{E}-03$ & 7.0E-02 \\
\hline 100 & $3.5 \mathrm{E}-04$ & $9.3 \mathrm{E}-01$ & 2.3E-06 & $6.2 \mathrm{E}-03$ & $1.3 \mathrm{E}-03$ & $6.6 \mathrm{E}-02$ \\
\hline 150 & $1.6 \mathrm{E}-04$ & $9.4 \mathrm{E}-01$ & $1.1 \mathrm{E}-06$ & $6.2 \mathrm{E}-03$ & 8.9E-04 & $5.4 \mathrm{E}-02$ \\
\hline 200 & $8.5 \mathrm{E}-05$ & $9.5 \mathrm{E}-01$ & $5.6 \mathrm{E}-07$ & $6.3 \mathrm{E}-03$ & 7.4E-04 & $4.8 \mathrm{E}-02$ \\
\hline 300 & $3.1 \mathrm{E}-05$ & $9.5 \mathrm{E}-01$ & $2.1 \mathrm{E}-07$ & $6.3 \mathrm{E}-03$ & $6.2 \mathrm{E}-04$ & 4.3E-02 \\
\hline 400 & $1.6 \mathrm{E}-05$ & $9.5 \mathrm{E}-01$ & $1.1 \mathrm{E}-07$ & $6.3 \mathrm{E}-03$ & 5.7E-04 & 4.1E-02 \\
\hline 500 & $1.2 \mathrm{E}-05$ & $9.5 \mathrm{E}-01$ & 7.7E-08 & $6.3 \mathrm{E}-03$ & 5.5E-04 & $4.0 \mathrm{E}-02$ \\
\hline 600 & $1.0 \mathrm{E}-05$ & $9.6 \mathrm{E}-01$ & $6.6 \mathrm{E}-08$ & $6.3 \mathrm{E}-03$ & $5.2 \mathrm{E}-04$ & $3.8 \mathrm{E}-02$ \\
\hline 700 & $9.3 \mathrm{E}-06$ & $9.6 \mathrm{E}-01$ & $6.2 \mathrm{E}-08$ & $6.4 \mathrm{E}-03$ & $5.0 \mathrm{E}-04$ & 3.7E-02 \\
\hline 800 & 8.8E-06 & $9.6 \mathrm{E}-01$ & $5.8 \mathrm{E}-08$ & $6.4 \mathrm{E}-03$ & $4.9 \mathrm{E}-04$ & $3.7 \mathrm{E}-02$ \\
\hline 900 & $8.4 \mathrm{E}-06$ & $9.6 \mathrm{E}-01$ & 5.6E-08 & $6.4 \mathrm{E}-03$ & $4.7 \mathrm{E}-04$ & $3.6 \mathrm{E}-02$ \\
\hline 1000 & $8.1 \mathrm{E}-06$ & $9.6 \mathrm{E}-01$ & $5.4 \mathrm{E}-08$ & $6.4 \mathrm{E}-03$ & $4.5 \mathrm{E}-04$ & $3.5 \mathrm{E}-02$ \\
\hline 1500 & $6.6 \mathrm{E}-06$ & $9.6 \mathrm{E}-01$ & 4.4E-08 & $6.4 \mathrm{E}-03$ & $3.8 \mathrm{E}-04$ & $3.1 \mathrm{E}-02$ \\
\hline 2000 & $5.5 \mathrm{E}-06$ & $9.7 \mathrm{E}-01$ & $3.6 \mathrm{E}-08$ & $6.4 \mathrm{E}-03$ & $3.1 \mathrm{E}-04$ & $2.8 \mathrm{E}-02$ \\
\hline 3000 & $3.8 \mathrm{E}-06$ & $9.7 \mathrm{E}-01$ & $2.5 \mathrm{E}-08$ & $6.4 \mathrm{E}-03$ & $2.2 \mathrm{E}-04$ & $2.4 \mathrm{E}-02$ \\
\hline 4000 & $2.8 \mathrm{E}-06$ & $9.7 \mathrm{E}-01$ & $1.8 \mathrm{E}-08$ & $6.5 \mathrm{E}-03$ & $1.5 \mathrm{E}-04$ & $2.0 \mathrm{E}-02$ \\
\hline 5000 & $2.1 \mathrm{E}-06$ & $9.8 \mathrm{E}-01$ & $1.4 \mathrm{E}-08$ & $6.5 \mathrm{E}-03$ & $1.0 \mathrm{E}-04$ & $1.8 \mathrm{E}-02$ \\
\hline 6000 & $1.6 \mathrm{E}-06$ & $9.8 \mathrm{E}-01$ & $1.1 \mathrm{E}-08$ & $6.5 \mathrm{E}-03$ & $7.2 \mathrm{E}-05$ & $1.6 \mathrm{E}-02$ \\
\hline 7000 & $1.3 \mathrm{E}-06$ & $9.8 \mathrm{E}-01$ & 8.6E-09 & $6.5 \mathrm{E}-03$ & $5.1 \mathrm{E}-05$ & $1.5 \mathrm{E}-02$ \\
\hline 8000 & $1.1 \mathrm{E}-06$ & $9.8 \mathrm{E}-01$ & 7.2E-09 & $6.5 \mathrm{E}-03$ & $3.6 \mathrm{E}-05$ & $1.3 \mathrm{E}-02$ \\
\hline 9000 & $9.3 \mathrm{E}-07$ & $9.8 \mathrm{E}-01$ & $6.2 \mathrm{E}-09$ & $6.5 \mathrm{E}-03$ & $2.5 \mathrm{E}-05$ & $1.2 \mathrm{E}-02$ \\
\hline 10000 & $8.1 \mathrm{E}-07$ & $9.8 \mathrm{E}-01$ & 5.4E-09 & $6.5 \mathrm{E}-03$ & $1.8 \mathrm{E}-05$ & $1.2 \mathrm{E}-02$ \\
\hline
\end{tabular}

${ }^{a} 24-\mathrm{h}$ excretion values for Day 1 refer to $0-24 \mathrm{~h}$ after intake, Day 2 to $24-48 \mathrm{~h}$ after intake, and so forth. Retention values for Day 1 refer to retention at $24 \mathrm{~h}$ after intake, for Day 2 at $48 \mathrm{~h}$, and so forth. 
Table 3.6 Model predictions of retention and excretion (multiple of daily intake) of uranium during continuous input of uranium into blood at a constant rate

\begin{tabular}{|c|c|c|c|c|c|c|}
\hline \multirow{2}{*}{$\begin{array}{l}\text { Day after start } \\
\text { of intake }^{a}\end{array}$} & \multicolumn{2}{|c|}{ Urine } & \multicolumn{2}{|c|}{ Feces } & \multirow{2}{*}{$\begin{array}{c}\text { Retained } \\
\text { in } \\
\text { kidneys }\end{array}$} & \multirow{2}{*}{$\begin{array}{c}\text { Retained } \\
\text { in total } \\
\text { body }\end{array}$} \\
\hline & $24 \mathrm{~h}$ & Cumulative & $24 \mathrm{~h}$ & Cumulative & & \\
\hline 1 & $5.2 \mathrm{E}-01$ & 5.2E-01 & 4.3E-04 & 4.3E-04 & $1.0 \mathrm{E}-01$ & 4.7E-01 \\
\hline 2 & $6.6 \mathrm{E}-01$ & $1.2 \mathrm{E}+00$ & $2.6 \mathrm{E}-03$ & $3.0 \mathrm{E}-03$ & $2.1 \mathrm{E}-01$ & $8.1 \mathrm{E}-01$ \\
\hline 3 & $6.8 \mathrm{E}-01$ & $1.9 \mathrm{E}+00$ & 4.3E-03 & 7.3E-03 & $3.1 \mathrm{E}-01$ & $1.1 \mathrm{E}+00$ \\
\hline 4 & $6.9 \mathrm{E}-01$ & $2.5 \mathrm{E}+00$ & 4.9E-03 & $1.2 \mathrm{E}-02$ & $4.0 \mathrm{E}-01$ & $1.4 \mathrm{E}+00$ \\
\hline 5 & 7.1E-01 & $3.3 \mathrm{E}+00$ & 5.1E-03 & $1.7 \mathrm{E}-02$ & 4.9E-01 & $1.7 \mathrm{E}+00$ \\
\hline 6 & 7.2E-01 & $4.0 \mathrm{E}+00$ & $5.2 \mathrm{E}-03$ & $2.3 \mathrm{E}-02$ & $5.6 \mathrm{E}-01$ & $2.0 \mathrm{E}+00$ \\
\hline 7 & 7.4E-01 & $4.7 \mathrm{E}+00$ & $5.3 \mathrm{E}-03$ & $2.8 \mathrm{E}-02$ & $6.3 \mathrm{E}-01$ & $2.3 \mathrm{E}+00$ \\
\hline 8 & 7.5E-01 & $5.5 \mathrm{E}+00$ & $5.3 \mathrm{E}-03$ & 3.3E-02 & 7.0E-01 & $2.5 \mathrm{E}+00$ \\
\hline 9 & 7.6E-01 & $6.2 \mathrm{E}+00$ & $5.4 \mathrm{E}-03$ & 3.9E-02 & 7.6E-01 & $2.7 \mathrm{E}+00$ \\
\hline 10 & 7.7E-01 & $7.0 \mathrm{E}+00$ & $5.4 \mathrm{E}-03$ & 4.4E-02 & $8.1 \mathrm{E}-01$ & $3.0 \mathrm{E}+00$ \\
\hline 15 & $8.1 \mathrm{E}-01$ & $1.1 \mathrm{E}+01$ & $5.6 \mathrm{E}-03$ & 7.2E-02 & $1.0 \mathrm{E}+00$ & $4.0 \mathrm{E}+00$ \\
\hline 20 & 8.4E-01 & $1.5 \mathrm{E}+01$ & $5.7 \mathrm{E}-03$ & $1.0 \mathrm{E}-01$ & $1.2 \mathrm{E}+00$ & $4.8 \mathrm{E}+00$ \\
\hline 30 & 8.7E-01 & $2.4 \mathrm{E}+01$ & $5.8 \mathrm{E}-03$ & $1.6 \mathrm{E}-01$ & $1.3 \mathrm{E}+00$ & $6.2 \mathrm{E}+00$ \\
\hline 40 & $8.9 \mathrm{E}-01$ & $3.2 \mathrm{E}+01$ & $5.9 \mathrm{E}-03$ & $2.2 \mathrm{E}-01$ & $1.4 \mathrm{E}+00$ & $7.4 \mathrm{E}+00$ \\
\hline 50 & $9.0 \mathrm{E}-01$ & $4.1 \mathrm{E}+01$ & $6.0 \mathrm{E}-03$ & 2.7E-01 & $1.5 \mathrm{E}+00$ & $8.4 \mathrm{E}+00$ \\
\hline 60 & $9.1 \mathrm{E}-01$ & $5.0 \mathrm{E}+01$ & $6.0 \mathrm{E}-03$ & 3.3E-01 & $1.5 \mathrm{E}+00$ & $9.4 \mathrm{E}+00$ \\
\hline 70 & $9.1 \mathrm{E}-01$ & $5.9 \mathrm{E}+01$ & $6.1 \mathrm{E}-03$ & 4.0E-01 & $1.5 \mathrm{E}+00$ & $1.0 \mathrm{E}+01$ \\
\hline 80 & $9.2 \mathrm{E}-01$ & $6.9 \mathrm{E}+01$ & $6.1 \mathrm{E}-03$ & 4.6E-01 & $1.5 \mathrm{E}+00$ & $1.1 \mathrm{E}+01$ \\
\hline 90 & $9.2 \mathrm{E}-01$ & $7.8 \mathrm{E}+01$ & $6.1 \mathrm{E}-03$ & $5.2 \mathrm{E}-01$ & $1.5 \mathrm{E}+00$ & $1.2 \mathrm{E}+01$ \\
\hline 100 & 9.3E-01 & $8.7 \mathrm{E}+01$ & $6.2 \mathrm{E}-03$ & $5.8 \mathrm{E}-01$ & $1.6 \mathrm{E}+00$ & $1.2 \mathrm{E}+01$ \\
\hline 150 & $9.4 \mathrm{E}-01$ & $1.3 \mathrm{E}+02$ & $6.2 \mathrm{E}-03$ & 8.9E-01 & $1.6 \mathrm{E}+00$ & $1.5 \mathrm{E}+01$ \\
\hline 200 & $9.5 \mathrm{E}-01$ & $1.8 \mathrm{E}+02$ & $6.3 \mathrm{E}-03$ & $1.2 \mathrm{E}+00$ & $1.6 \mathrm{E}+00$ & $1.8 \mathrm{E}+01$ \\
\hline 300 & $9.5 \mathrm{E}-01$ & $2.8 \mathrm{E}+02$ & $6.3 \mathrm{E}-03$ & $1.8 \mathrm{E}+00$ & $1.7 \mathrm{E}+00$ & $2.2 \mathrm{E}+01$ \\
\hline 400 & $9.5 \mathrm{E}-01$ & $3.7 \mathrm{E}+02$ & $6.3 \mathrm{E}-03$ & $2.5 \mathrm{E}+00$ & $1.8 \mathrm{E}+00$ & $2.7 \mathrm{E}+01$ \\
\hline 500 & $9.5 \mathrm{E}-01$ & $4.7 \mathrm{E}+02$ & 6.3E-03 & $3.1 \mathrm{E}+00$ & $1.8 \mathrm{E}+00$ & $3.1 \mathrm{E}+01$ \\
\hline 600 & 9.6E-01 & $5.6 \mathrm{E}+02$ & $6.3 \mathrm{E}-03$ & $3.7 \mathrm{E}+00$ & $1.9 \mathrm{E}+00$ & $3.5 \mathrm{E}+01$ \\
\hline 700 & 9.6E-01 & $6.6 \mathrm{E}+02$ & $6.4 \mathrm{E}-03$ & $4.4 \mathrm{E}+00$ & $1.9 \mathrm{E}+00$ & $3.8 \mathrm{E}+01$ \\
\hline 800 & $9.6 \mathrm{E}-01$ & $7.5 \mathrm{E}+02$ & $6.4 \mathrm{E}-03$ & $5.0 \mathrm{E}+00$ & $2.0 \mathrm{E}+00$ & $4.2 \mathrm{E}+01$ \\
\hline 900 & 9.6E-01 & $8.5 \mathrm{E}+02$ & $6.4 \mathrm{E}-03$ & $5.6 \mathrm{E}+00$ & $2.0 \mathrm{E}+00$ & $4.6 \mathrm{E}+01$ \\
\hline 1000 & $9.6 \mathrm{E}-01$ & $9.4 \mathrm{E}+02$ & $6.4 \mathrm{E}-03$ & $6.3 \mathrm{E}+00$ & $2.1 \mathrm{E}+00$ & $4.9 \mathrm{E}+01$ \\
\hline 1500 & $9.6 \mathrm{E}-01$ & $1.4 \mathrm{E}+03$ & $6.4 \mathrm{E}-03$ & $9.5 \mathrm{E}+00$ & $2.3 \mathrm{E}+00$ & $6.6 \mathrm{E}+01$ \\
\hline 2000 & 9.7E-01 & $1.9 \mathrm{E}+03$ & $6.4 \mathrm{E}-03$ & $1.3 \mathrm{E}+01$ & $2.5 \mathrm{E}+00$ & $8.0 \mathrm{E}+01$ \\
\hline 3000 & 9.7E-01 & $2.9 \mathrm{E}+03$ & $6.4 \mathrm{E}-03$ & $1.9 \mathrm{E}+01$ & $2.7 \mathrm{E}+00$ & $1.1 \mathrm{E}+02$ \\
\hline 4000 & 9.7E-01 & $3.8 \mathrm{E}+03$ & $6.5 \mathrm{E}-03$ & $2.6 \mathrm{E}+01$ & $2.9 \mathrm{E}+00$ & $1.3 \mathrm{E}+02$ \\
\hline 5000 & $9.8 \mathrm{E}-01$ & $4.8 \mathrm{E}+03$ & $6.5 \mathrm{E}-03$ & $3.2 \mathrm{E}+01$ & $3.0 \mathrm{E}+00$ & $1.5 \mathrm{E}+02$ \\
\hline 6000 & $9.8 \mathrm{E}-01$ & $5.8 \mathrm{E}+03$ & $6.5 \mathrm{E}-03$ & $3.9 \mathrm{E}+01$ & $3.1 \mathrm{E}+00$ & $1.6 \mathrm{E}+02$ \\
\hline 7000 & $9.8 \mathrm{E}-01$ & $6.8 \mathrm{E}+03$ & $6.5 \mathrm{E}-03$ & $4.5 \mathrm{E}+01$ & $3.2 \mathrm{E}+00$ & $1.8 \mathrm{E}+02$ \\
\hline 8000 & $9.8 \mathrm{E}-01$ & $7.8 \mathrm{E}+03$ & $6.5 \mathrm{E}-03$ & $5.2 \mathrm{E}+01$ & $3.2 \mathrm{E}+00$ & $1.9 \mathrm{E}+02$ \\
\hline 9000 & 9.8E-01 & $8.7 \mathrm{E}+03$ & $6.5 \mathrm{E}-03$ & $5.8 \mathrm{E}+01$ & $3.2 \mathrm{E}+00$ & $2.1 \mathrm{E}+02$ \\
\hline 10000 & $9.8 \mathrm{E}-01$ & $9.7 \mathrm{E}+03$ & $6.5 \mathrm{E}-03$ & $6.5 \mathrm{E}+01$ & $3.3 \mathrm{E}+00$ & $2.2 \mathrm{E}+02$ \\
\hline
\end{tabular}

${ }^{a} 24-\mathrm{h}$ excretion for Day 1 refers to $0-24 \mathrm{~h}$ after start of intake, for Day 2 to $24-48 \mathrm{~h}$, and so forth. Retention values for Day 1 refer to retention at $24 \mathrm{~h}$ after start of intake, for Day 2 at $48 \mathrm{~h}$, and so forth. 
Table 3.7 Model predictions of retention and excretion of uranium (fraction of intake) following acute inhalation of a relatively soluble form (Type F, $5 \mu \mathrm{m}$ AMAD)

\begin{tabular}{|c|c|c|c|c|c|}
\hline $\begin{array}{c}\text { Day after } \\
\text { intake }^{a}\end{array}$ & $\begin{array}{c}\text { 24-h urinary } \\
\text { excretion }\end{array}$ & $\begin{array}{l}\text { 24-h fecal } \\
\text { excretion }\end{array}$ & $\begin{array}{c}\begin{array}{c}\text { Retained in } \\
\text { lungs }\end{array} \\
\end{array}$ & $\begin{array}{c}\text { Retained in } \\
\text { kidneys }\end{array}$ & $\begin{array}{c}\text { Retained in } \\
\text { total body }\end{array}$ \\
\hline 1 & $1.8 \mathrm{E}-01$ & $4.2 \mathrm{E}-02$ & $0.0 \mathrm{E}+00$ & $3.2 \mathrm{E}-02$ & $3.8 \mathrm{E}-01$ \\
\hline 2 & $6.4 \mathrm{E}-03$ & 9.3E-02 & $0.0 \mathrm{E}+00$ & 2.9E-02 & 2.0E-01 \\
\hline 3 & $5.1 \mathrm{E}-03$ & $4.5 \mathrm{E}-02$ & $0.0 \mathrm{E}+00$ & 2.7E-02 & $1.2 \mathrm{E}-01$ \\
\hline 4 & 4.6E-03 & $1.3 \mathrm{E}-02$ & $0.0 \mathrm{E}+00$ & $2.5 \mathrm{E}-02$ & $9.4 \mathrm{E}-02$ \\
\hline 5 & 4.2E-03 & $3.2 \mathrm{E}-03$ & $0.0 \mathrm{E}+00$ & 2.3E-02 & 8.3E-02 \\
\hline 6 & $3.8 \mathrm{E}-03$ & 7.0E-04 & $0.0 \mathrm{E}+00$ & $2.1 \mathrm{E}-02$ & 7.7E-02 \\
\hline 7 & $3.5 \mathrm{E}-03$ & $1.5 \mathrm{E}-04$ & $0.0 \mathrm{E}+00$ & $1.9 \mathrm{E}-02$ & 7.3E-02 \\
\hline 8 & $3.2 \mathrm{E}-03$ & $3.7 \mathrm{E}-05$ & $0.0 \mathrm{E}+00$ & $1.8 \mathrm{E}-02$ & 6.9E-02 \\
\hline 9 & 2.9E-03 & $1.6 \mathrm{E}-05$ & $0.0 \mathrm{E}+00$ & $1.6 \mathrm{E}-02$ & $6.6 \mathrm{E}-02$ \\
\hline 10 & 2.7E-03 & $1.1 \mathrm{E}-05$ & $0.0 \mathrm{E}+00$ & $1.5 \mathrm{E}-02$ & $6.3 \mathrm{E}-02$ \\
\hline 15 & $1.7 \mathrm{E}-03$ & $6.6 \mathrm{E}-06$ & $0.0 \mathrm{E}+00$ & $9.9 \mathrm{E}-03$ & $5.3 \mathrm{E}-02$ \\
\hline 20 & $1.2 \mathrm{E}-03$ & 4.9E-06 & $0.0 \mathrm{E}+00$ & $6.6 \mathrm{E}-03$ & $4.5 \mathrm{E}-02$ \\
\hline 30 & $6.6 \mathrm{E}-04$ & $3.1 \mathrm{E}-06$ & $0.0 \mathrm{E}+00$ & $3.1 \mathrm{E}-03$ & $3.6 \mathrm{E}-02$ \\
\hline 40 & $4.2 \mathrm{E}-04$ & $2.3 \mathrm{E}-06$ & $0.0 \mathrm{E}+00$ & $1.6 \mathrm{E}-03$ & $3.1 \mathrm{E}-02$ \\
\hline 50 & $3.0 \mathrm{E}-04$ & $1.7 \mathrm{E}-06$ & $0.0 \mathrm{E}+00$ & $1.0 \mathrm{E}-03$ & $2.8 \mathrm{E}-02$ \\
\hline 60 & $2.2 \mathrm{E}-04$ & $1.4 \mathrm{E}-06$ & $0.0 \mathrm{E}+00$ & 7.0E-04 & $2.5 \mathrm{E}-02$ \\
\hline 70 & $1.8 \mathrm{E}-04$ & $1.1 \mathrm{E}-06$ & $0.0 \mathrm{E}+00$ & $5.5 \mathrm{E}-04$ & $2.3 \mathrm{E}-02$ \\
\hline 80 & $1.4 \mathrm{E}-04$ & $9.3 \mathrm{E}-07$ & $0.0 \mathrm{E}+00$ & 4.6E-04 & $2.1 \mathrm{E}-02$ \\
\hline 90 & $1.2 \mathrm{E}-04$ & $7.8 \mathrm{E}-07$ & $0.0 \mathrm{E}+00$ & 4.0E-04 & $2.0 \mathrm{E}-02$ \\
\hline 100 & 9.9E-05 & $6.5 \mathrm{E}-07$ & $0.0 \mathrm{E}+00$ & $3.6 \mathrm{E}-04$ & 1.9E-02 \\
\hline 150 & $4.6 \mathrm{E}-05$ & $3.0 \mathrm{E}-07$ & $0.0 \mathrm{E}+00$ & $2.5 \mathrm{E}-04$ & $1.5 \mathrm{E}-02$ \\
\hline 200 & $2.4 \mathrm{E}-05$ & $1.6 \mathrm{E}-07$ & $0.0 \mathrm{E}+00$ & $2.1 \mathrm{E}-04$ & $1.4 \mathrm{E}-02$ \\
\hline 300 & 8.8E-06 & 5.8E-08 & $0.0 \mathrm{E}+00$ & $1.8 \mathrm{E}-04$ & $1.2 \mathrm{E}-02$ \\
\hline 400 & 4.6E-06 & $3.0 \mathrm{E}-08$ & $0.0 \mathrm{E}+00$ & $1.6 \mathrm{E}-04$ & $1.2 \mathrm{E}-02$ \\
\hline 500 & $3.3 \mathrm{E}-06$ & 2.2E-08 & $0.0 \mathrm{E}+00$ & $1.6 \mathrm{E}-04$ & $1.1 \mathrm{E}-02$ \\
\hline 600 & $2.8 \mathrm{E}-06$ & 1.9E-08 & $0.0 \mathrm{E}+00$ & $1.5 \mathrm{E}-04$ & $1.1 \mathrm{E}-02$ \\
\hline 700 & $2.6 \mathrm{E}-06$ & $1.8 \mathrm{E}-08$ & $0.0 \mathrm{E}+00$ & $1.4 \mathrm{E}-04$ & $1.1 \mathrm{E}-02$ \\
\hline 800 & $2.5 \mathrm{E}-06$ & $1.7 \mathrm{E}-08$ & $0.0 \mathrm{E}+00$ & $1.4 \mathrm{E}-04$ & $1.0 \mathrm{E}-02$ \\
\hline 900 & $2.4 \mathrm{E}-06$ & $1.6 \mathrm{E}-08$ & $0.0 \mathrm{E}+00$ & $1.3 \mathrm{E}-04$ & $1.0 \mathrm{E}-02$ \\
\hline 1000 & $2.3 \mathrm{E}-06$ & $1.5 \mathrm{E}-08$ & $0.0 \mathrm{E}+00$ & $1.3 \mathrm{E}-04$ & $9.9 \mathrm{E}-03$ \\
\hline 1500 & $1.9 \mathrm{E}-06$ & $1.3 \mathrm{E}-08$ & $0.0 \mathrm{E}+00$ & $1.1 \mathrm{E}-04$ & 8.9E-03 \\
\hline 2000 & $1.6 \mathrm{E}-06$ & $1.0 \mathrm{E}-08$ & $0.0 \mathrm{E}+00$ & 8.9E-05 & 8.0E-03 \\
\hline 3000 & $1.1 \mathrm{E}-06$ & 7.2E-09 & $0.0 \mathrm{E}+00$ & $6.2 \mathrm{E}-05$ & $6.7 \mathrm{E}-03$ \\
\hline 4000 & $7.8 \mathrm{E}-07$ & $5.2 \mathrm{E}-09$ & $0.0 \mathrm{E}+00$ & 4.3E-05 & $5.8 \mathrm{E}-03$ \\
\hline 5000 & $5.9 \mathrm{E}-07$ & 3.9E-09 & $0.0 \mathrm{E}+00$ & $3.0 \mathrm{E}-05$ & $5.1 \mathrm{E}-03$ \\
\hline 6000 & 4.6E-07 & $3.0 \mathrm{E}-09$ & $0.0 \mathrm{E}+00$ & $2.1 \mathrm{E}-05$ & $4.6 \mathrm{E}-03$ \\
\hline 7000 & $3.7 \mathrm{E}-07$ & 2.5E-09 & $0.0 \mathrm{E}+00$ & $1.4 \mathrm{E}-05$ & 4.2E-03 \\
\hline 8000 & $3.1 \mathrm{E}-07$ & 2.1E-09 & $0.0 \mathrm{E}+00$ & $1.0 \mathrm{E}-05$ & $3.8 \mathrm{E}-03$ \\
\hline 9000 & $2.7 \mathrm{E}-07$ & 1.8E-09 & $0.0 \mathrm{E}+00$ & 7.2E-06 & $3.5 \mathrm{E}-03$ \\
\hline 10000 & 2.3E-07 & $1.5 \mathrm{E}-09$ & $0.0 \mathrm{E}+00$ & $5.1 \mathrm{E}-06$ & $3.3 \mathrm{E}-03$ \\
\hline
\end{tabular}

${ }^{a} 24-\mathrm{h}$ excretion values for Day 1 after intake refer to cumulative excretion 0-24 $\mathrm{h}$ after intake, Day 2 to $24-48 \mathrm{~h}$ after intake, and so forth. Retention values for Day 1 refer to retention at $24 \mathrm{~h}$ after intake, for Day 2 at $48 \mathrm{~h}$, and so forth.

${ }^{b}$ Total content of thoracic compartments shown in Figure 3.1. 
Table 3.8 Model predictions of retention and excretion of uranium (fraction of intake) following acute inhalation of a moderately soluble form (Type M, 5 um AMAD)

\begin{tabular}{|c|c|c|c|c|c|}
\hline $\begin{array}{l}\text { Day after } \\
\text { intake }^{a}\end{array}$ & $\begin{array}{l}\text { 24-h urinary } \\
\text { excretion }\end{array}$ & $\begin{array}{l}\text { 24-h fecal } \\
\text { excretion }\end{array}$ & $\begin{array}{c}\text { Retained in } \\
\text { lungs }\end{array}$ & $\begin{array}{l}\text { Retained in } \\
\text { kidneys }\end{array}$ & $\begin{array}{c}\text { Retained in } \\
\text { total body }\end{array}$ \\
\hline 1 & $2.3 \mathrm{E}-02$ & $8.0 \mathrm{E}-02$ & $5.8 \mathrm{E}-02$ & $4.1 \mathrm{E}-03$ & $5.0 \mathrm{E}-01$ \\
\hline 2 & $1.2 \mathrm{E}-03$ & $1.8 \mathrm{E}-01$ & $5.6 \mathrm{E}-02$ & $3.8 \mathrm{E}-03$ & $2.4 \mathrm{E}-01$ \\
\hline 3 & 8.6E-04 & $9.0 \mathrm{E}-02$ & $5.5 \mathrm{E}-02$ & $3.5 \mathrm{E}-03$ & $1.2 \mathrm{E}-01$ \\
\hline 4 & 7.9E-04 & $2.7 \mathrm{E}-02$ & $5.4 \mathrm{E}-02$ & $3.3 \mathrm{E}-03$ & $8.1 \mathrm{E}-02$ \\
\hline 5 & 7.4E-04 & $7.0 \mathrm{E}-03$ & 5.3E-02 & $3.0 \mathrm{E}-03$ & $6.9 \mathrm{E}-02$ \\
\hline 6 & 6.9E-04 & $1.9 \mathrm{E}-03$ & 5.3E-02 & 2.8E-03 & $6.5 \mathrm{E}-02$ \\
\hline 7 & $6.5 \mathrm{E}-04$ & $7.9 \mathrm{E}-04$ & $5.2 \mathrm{E}-02$ & $2.6 \mathrm{E}-03$ & $6.3 \mathrm{E}-02$ \\
\hline 8 & $6.1 \mathrm{E}-04$ & $5.5 \mathrm{E}-04$ & $5.1 \mathrm{E}-02$ & $2.5 \mathrm{E}-03$ & $6.2 \mathrm{E}-02$ \\
\hline 9 & 5.8E-04 & $5.0 \mathrm{E}-04$ & $5.0 \mathrm{E}-02$ & 2.3E-03 & $6.1 \mathrm{E}-02$ \\
\hline 10 & $5.5 \mathrm{E}-04$ & 4.7E-04 & $5.0 \mathrm{E}-02$ & $2.1 \mathrm{E}-03$ & $5.9 \mathrm{E}-02$ \\
\hline 15 & 4.2E-04 & $4.0 \mathrm{E}-04$ & 4.6E-02 & $1.5 \mathrm{E}-03$ & $5.5 \mathrm{E}-02$ \\
\hline 20 & $3.5 \mathrm{E}-04$ & $3.5 \mathrm{E}-04$ & 4.3E-02 & $1.1 \mathrm{E}-03$ & $5.1 \mathrm{E}-02$ \\
\hline 30 & $2.6 \mathrm{E}-04$ & $2.7 \mathrm{E}-04$ & $3.8 \mathrm{E}-02$ & 6.9E-04 & $4.5 \mathrm{E}-02$ \\
\hline 40 & 2.2E-04 & $2.1 \mathrm{E}-04$ & $3.4 \mathrm{E}-02$ & 4.9E-04 & $4.0 \mathrm{E}-02$ \\
\hline 50 & $1.9 \mathrm{E}-04$ & $1.6 \mathrm{E}-04$ & $3.1 \mathrm{E}-02$ & 3.9E-04 & $3.7 \mathrm{E}-02$ \\
\hline 60 & $1.7 \mathrm{E}-04$ & $1.2 \mathrm{E}-04$ & $2.8 \mathrm{E}-02$ & $3.4 \mathrm{E}-04$ & $3.3 \mathrm{E}-02$ \\
\hline 70 & $1.5 \mathrm{E}-04$ & $9.7 \mathrm{E}-05$ & $2.6 \mathrm{E}-02$ & $3.0 \mathrm{E}-04$ & $3.1 \mathrm{E}-02$ \\
\hline 80 & $1.4 \mathrm{E}-04$ & 7.7E-05 & $2.4 \mathrm{E}-02$ & $2.7 \mathrm{E}-04$ & 2.8E-02 \\
\hline 90 & $1.2 \mathrm{E}-04$ & $6.2 \mathrm{E}-05$ & $2.2 \mathrm{E}-02$ & $2.5 \mathrm{E}-04$ & $2.6 \mathrm{E}-02$ \\
\hline 100 & $1.1 \mathrm{E}-04$ & $5.0 \mathrm{E}-05$ & 2.0E-02 & 2.3E-04 & $2.5 \mathrm{E}-02$ \\
\hline 150 & 7.9E-05 & $2.1 \mathrm{E}-05$ & $1.4 \mathrm{E}-02$ & $1.7 \mathrm{E}-04$ & $1.8 \mathrm{E}-02$ \\
\hline 200 & 5.7E-05 & $1.1 \mathrm{E}-05$ & $1.1 \mathrm{E}-02$ & $1.3 \mathrm{E}-04$ & $1.4 \mathrm{E}-02$ \\
\hline 300 & $3.2 \mathrm{E}-05$ & $5.2 \mathrm{E}-06$ & $5.8 \mathrm{E}-03$ & $9.1 \mathrm{E}-05$ & $9.1 \mathrm{E}-03$ \\
\hline 400 & $1.8 \mathrm{E}-05$ & $2.8 \mathrm{E}-06$ & $3.3 \mathrm{E}-03$ & $6.7 \mathrm{E}-05$ & $6.3 \mathrm{E}-03$ \\
\hline 500 & $1.0 \mathrm{E}-05$ & $1.5 \mathrm{E}-06$ & $1.8 \mathrm{E}-03$ & $5.4 \mathrm{E}-05$ & 4.7E-03 \\
\hline 600 & $6.0 \mathrm{E}-06$ & $8.4 \mathrm{E}-07$ & $1.0 \mathrm{E}-03$ & 4.6E-05 & $3.8 \mathrm{E}-03$ \\
\hline 700 & $3.6 \mathrm{E}-06$ & 4.6E-07 & $5.7 \mathrm{E}-04$ & $4.1 \mathrm{E}-05$ & 3.3E-03 \\
\hline 800 & 2.3E-06 & $2.6 \mathrm{E}-07$ & $3.2 \mathrm{E}-04$ & $3.7 \mathrm{E}-05$ & 2.9E-03 \\
\hline 900 & $1.6 \mathrm{E}-06$ & $1.4 \mathrm{E}-07$ & $1.8 \mathrm{E}-04$ & $3.5 \mathrm{E}-05$ & $2.7 \mathrm{E}-03$ \\
\hline 1000 & $1.1 \mathrm{E}-06$ & 8.1E-08 & $1.0 \mathrm{E}-04$ & 3.3E-05 & $2.6 \mathrm{E}-03$ \\
\hline 1500 & $5.1 \mathrm{E}-07$ & 7.1E-09 & 5.9E-06 & $2.7 \mathrm{E}-05$ & $2.2 \mathrm{E}-03$ \\
\hline 2000 & 4.0E-07 & 2.8E-09 & 3.6E-07 & $2.2 \mathrm{E}-05$ & $2.0 \mathrm{E}-03$ \\
\hline 3000 & 2.7E-07 & $1.8 \mathrm{E}-09$ & $1.6 \mathrm{E}-09$ & $1.6 \mathrm{E}-05$ & $1.7 \mathrm{E}-03$ \\
\hline 4000 & $2.0 \mathrm{E}-07$ & $1.3 \mathrm{E}-09$ & 8.2E-12 & $1.1 \mathrm{E}-05$ & $1.4 \mathrm{E}-03$ \\
\hline 5000 & $1.5 \mathrm{E}-07$ & $9.8 \mathrm{E}-10$ & $4.7 E-14$ & $7.5 \mathrm{E}-06$ & $1.3 \mathrm{E}-03$ \\
\hline 6000 & $1.1 \mathrm{E}-07$ & 7.6E-10 & $2.8 \mathrm{E}-16$ & $5.2 \mathrm{E}-06$ & $1.1 \mathrm{E}-03$ \\
\hline 7000 & 9.2E-08 & $6.1 \mathrm{E}-10$ & $1.7 \mathrm{E}-18$ & $3.6 \mathrm{E}-06$ & $1.0 \mathrm{E}-03$ \\
\hline 8000 & 7.7E-08 & $5.1 \mathrm{E}-10$ & $1.1 \mathrm{E}-20$ & $2.6 \mathrm{E}-06$ & $9.4 \mathrm{E}-04$ \\
\hline 9000 & $6.6 \mathrm{E}-08$ & $4.4 \mathrm{E}-10$ & $6.7 \mathrm{E}-23$ & 1.8E-06 & 8.7E-04 \\
\hline 10000 & 5.7E-08 & $3.8 \mathrm{E}-10$ & $4.2 \mathrm{E}-25$ & $1.3 \mathrm{E}-06$ & $8.1 \mathrm{E}-04$ \\
\hline
\end{tabular}

${ }^{a} 24-\mathrm{h}$ excretion values for Day 1 after intake refer to cumulative excretion $0-24 \mathrm{~h}$ after intake, Day 2 to $24-48 \mathrm{~h}$ after intake, and so forth. Retention values for Day 1 refer to retention at $24 \mathrm{~h}$ after intake, for Day 2 at $48 \mathrm{~h}$, and so forth.

${ }^{b}$ Total content of thoracic compartments shown in Figure 3.1. 
Table 3.9 Model predictions of retention and excretion of uranium (fraction of intake) following acute inhalation of a relatively insoluble form (Type $S, 5 \mu \mathrm{m}$ AMAD)

\begin{tabular}{|c|c|c|c|c|c|}
\hline $\begin{array}{c}\text { Day after } \\
\text { intake }^{a}\end{array}$ & $\begin{array}{c}\text { 24-h urinary } \\
\text { excretion }\end{array}$ & $\begin{array}{l}\text { 24-h fecal } \\
\text { excretion }\end{array}$ & $\begin{array}{c}\begin{array}{c}\text { Retained in } \\
\text { lungs }\end{array} \\
\end{array}$ & $\begin{array}{c}\text { Retained in } \\
\text { kidneys }\end{array}$ & $\begin{array}{c}\text { Retained in } \\
\text { total body }\end{array}$ \\
\hline 1 & $7.1 \mathrm{E}-04$ & $8.6 \mathrm{E}-02$ & $6.4 \mathrm{E}-02$ & $1.3 \mathrm{E}-04$ & $5.2 \mathrm{E}-01$ \\
\hline 2 & 4.6E-05 & $2.0 \mathrm{E}-01$ & $6.3 \mathrm{E}-02$ & $1.2 \mathrm{E}-04$ & $2.5 \mathrm{E}-01$ \\
\hline 3 & $2.6 \mathrm{E}-05$ & 9.7E-02 & $6.2 \mathrm{E}-02$ & $1.1 \mathrm{E}-04$ & $1.2 \mathrm{E}-01$ \\
\hline 4 & $2.4 \mathrm{E}-05$ & $3.0 \mathrm{E}-02$ & $6.1 \mathrm{E}-02$ & $1.0 \mathrm{E}-04$ & 7.8E-02 \\
\hline 5 & $2.2 \mathrm{E}-05$ & 7.6E-03 & $6.1 \mathrm{E}-02$ & $9.6 \mathrm{E}-05$ & $6.6 \mathrm{E}-02$ \\
\hline 6 & $2.1 \mathrm{E}-05$ & $2.1 \mathrm{E}-03$ & $6.0 \mathrm{E}-02$ & 8.9E-05 & $6.3 \mathrm{E}-02$ \\
\hline 7 & $1.9 \mathrm{E}-05$ & 8.9E-04 & $6.0 \mathrm{E}-02$ & 8.2E-05 & $6.1 \mathrm{E}-02$ \\
\hline 8 & $1.8 \mathrm{E}-05$ & $6.3 \mathrm{E}-04$ & $5.9 \mathrm{E}-02$ & $7.6 \mathrm{E}-05$ & $6.1 \mathrm{E}-02$ \\
\hline 9 & $1.7 \mathrm{E}-05$ & 5.8E-04 & 5.8E-02 & 7.0E-05 & $6.0 \mathrm{E}-02$ \\
\hline 10 & $1.6 \mathrm{E}-05$ & $5.5 \mathrm{E}-04$ & $5.8 \mathrm{E}-02$ & $6.6 \mathrm{E}-05$ & $5.9 \mathrm{E}-02$ \\
\hline 15 & $1.2 \mathrm{E}-05$ & $4.9 \mathrm{E}-04$ & $5.5 \mathrm{E}-02$ & 4.6E-05 & $5.7 \mathrm{E}-02$ \\
\hline 20 & $1.0 \mathrm{E}-05$ & 4.3E-04 & 5.3E-02 & $3.4 \mathrm{E}-05$ & $5.4 \mathrm{E}-02$ \\
\hline 30 & 7.6E-06 & $3.5 \mathrm{E}-04$ & 4.9E-02 & $2.0 \mathrm{E}-05$ & $5.0 \mathrm{E}-02$ \\
\hline 40 & $6.4 \mathrm{E}-06$ & $2.8 \mathrm{E}-04$ & 4.6E-02 & $1.4 \mathrm{E}-05$ & 4.7E-02 \\
\hline 50 & $5.7 \mathrm{E}-06$ & $2.3 \mathrm{E}-04$ & 4.4E-02 & $1.2 \mathrm{E}-05$ & $4.5 \mathrm{E}-02$ \\
\hline 60 & $5.2 \mathrm{E}-06$ & $1.8 \mathrm{E}-04$ & $4.2 \mathrm{E}-02$ & $1.0 \mathrm{E}-05$ & $4.2 \mathrm{E}-02$ \\
\hline 70 & $4.8 \mathrm{E}-06$ & $1.5 \mathrm{E}-04$ & $4.0 \mathrm{E}-02$ & $9.3 \mathrm{E}-06$ & 4.1E-02 \\
\hline 80 & $4.5 \mathrm{E}-06$ & $1.3 \mathrm{E}-04$ & 3.9E-02 & 8.7E-06 & $3.9 \mathrm{E}-02$ \\
\hline 90 & 4.3E-06 & $1.1 \mathrm{E}-04$ & $3.8 \mathrm{E}-02$ & 8.2E-06 & $3.8 \mathrm{E}-02$ \\
\hline 100 & 4.1E-06 & $9.0 \mathrm{E}-05$ & $3.7 \mathrm{E}-02$ & 7.8E-06 & 3.7E-02 \\
\hline 150 & $3.5 \mathrm{E}-06$ & $4.8 \mathrm{E}-05$ & $3.3 \mathrm{E}-02$ & $6.8 \mathrm{E}-06$ & $3.4 \mathrm{E}-02$ \\
\hline 200 & $3.2 \mathrm{E}-06$ & $3.3 \mathrm{E}-05$ & $3.1 \mathrm{E}-02$ & $6.4 \mathrm{E}-06$ & $3.2 \mathrm{E}-02$ \\
\hline 300 & $2.8 \mathrm{E}-06$ & $2.4 \mathrm{E}-05$ & $2.8 \mathrm{E}-02$ & 5.9E-06 & $2.9 \mathrm{E}-02$ \\
\hline 400 & $2.6 \mathrm{E}-06$ & $2.1 \mathrm{E}-05$ & $2.6 \mathrm{E}-02$ & $5.6 \mathrm{E}-06$ & $2.6 \mathrm{E}-02$ \\
\hline 500 & 2.3E-06 & $1.9 \mathrm{E}-05$ & 2.3E-02 & 5.3E-06 & $2.4 \mathrm{E}-02$ \\
\hline 600 & $2.1 \mathrm{E}-06$ & $1.7 \mathrm{E}-05$ & $2.1 \mathrm{E}-02$ & $5.1 \mathrm{E}-06$ & $2.2 \mathrm{E}-02$ \\
\hline 700 & 2.0E-06 & $1.5 \mathrm{E}-05$ & 2.0E-02 & 4.9E-06 & $2.0 \mathrm{E}-02$ \\
\hline 800 & $1.8 \mathrm{E}-06$ & $1.4 \mathrm{E}-05$ & $1.8 \mathrm{E}-02$ & 4.7E-06 & $1.8 \mathrm{E}-02$ \\
\hline 900 & $1.7 \mathrm{E}-06$ & $1.2 \mathrm{E}-05$ & $1.6 \mathrm{E}-02$ & 4.5E-06 & $1.7 \mathrm{E}-02$ \\
\hline 1000 & $1.5 \mathrm{E}-06$ & $1.1 \mathrm{E}-05$ & $1.5 \mathrm{E}-02$ & 4.3E-06 & $1.6 \mathrm{E}-02$ \\
\hline 1500 & $1.0 \mathrm{E}-06$ & $6.5 \mathrm{E}-06$ & $1.0 \mathrm{E}-02$ & $3.6 \mathrm{E}-06$ & $1.1 \mathrm{E}-02$ \\
\hline 2000 & 7.5E-07 & $3.9 \mathrm{E}-06$ & 7.3E-03 & $3.1 \mathrm{E}-06$ & 7.6E-03 \\
\hline 3000 & $4.5 \mathrm{E}-07$ & $1.5 \mathrm{E}-06$ & 4.3E-03 & 2.3E-06 & 4.6E-03 \\
\hline 4000 & $3.2 \mathrm{E}-07$ & $6.1 \mathrm{E}-07$ & $3.0 \mathrm{E}-03$ & $1.8 \mathrm{E}-06$ & $3.2 \mathrm{E}-03$ \\
\hline 5000 & $2.5 \mathrm{E}-07$ & $3.1 \mathrm{E}-07$ & $2.3 \mathrm{E}-03$ & $1.4 \mathrm{E}-06$ & $2.5 \mathrm{E}-03$ \\
\hline 6000 & $2.0 \mathrm{E}-07$ & $1.9 \mathrm{E}-07$ & $1.8 \mathrm{E}-03$ & $1.2 \mathrm{E}-06$ & $2.1 \mathrm{E}-03$ \\
\hline 7000 & $1.7 \mathrm{E}-07$ & $1.3 \mathrm{E}-07$ & $1.5 \mathrm{E}-03$ & 9.4E-07 & $1.7 \mathrm{E}-03$ \\
\hline 8000 & $1.4 \mathrm{E}-07$ & 9.7E-08 & $1.3 \mathrm{E}-03$ & 7.7E-07 & $1.5 \mathrm{E}-03$ \\
\hline 9000 & $1.2 \mathrm{E}-07$ & 7.6E-08 & $1.1 \mathrm{E}-03$ & $6.3 \mathrm{E}-07$ & $1.2 \mathrm{E}-03$ \\
\hline 10000 & $1.0 \mathrm{E}-07$ & $6.0 \mathrm{E}-08$ & 8.9E-04 & $5.3 \mathrm{E}-07$ & $1.1 \mathrm{E}-03$ \\
\hline
\end{tabular}

${ }^{a} 24-\mathrm{h}$ excretion values for Day 1 after intake refer to cumulative excretion 0-24 h after intake, Day 2 to $24-48 \mathrm{~h}$ after intake, and so forth. Retention values for Day 1 refer to retention at $24 \mathrm{~h}$ after intake, for Day 2 at $48 \mathrm{~h}$, and so forth.

${ }^{b}$ Total content of thoracic compartments shown in Figure 3.1. 
Table 3.10 Model predictions of retention and excretion of uranium (multiple of daily intake) as a function of time after start of continuous inhalation of a relatively soluble form (Type F, $5 \mu \mathrm{m}$ AMAD)

\begin{tabular}{|c|c|c|c|c|c|}
\hline $\begin{array}{c}\text { Days after } \\
\text { start of } \\
\text { intake }^{a}\end{array}$ & $\begin{array}{c}\text { 24-h } \\
\text { urinary } \\
\text { excretion }\end{array}$ & $\begin{array}{l}\text { 24-h fecal } \\
\text { excretion }\end{array}$ & $\begin{array}{l}\text { Retained in } \\
\text { lungs }^{b}\end{array}$ & $\begin{array}{l}\text { Retained in } \\
\text { kidneys }\end{array}$ & $\begin{array}{l}\text { Retained in } \\
\text { total body }\end{array}$ \\
\hline 1 & $1.5 \mathrm{E}-01$ & $1.1 \mathrm{E}-02$ & $8.1 \mathrm{E}-04$ & $3.0 \mathrm{E}-02$ & $5.3 \mathrm{E}-01$ \\
\hline 2 & $1.8 \mathrm{E}-01$ & $9.0 \mathrm{E}-02$ & 8.1E-04 & $6.0 \mathrm{E}-02$ & $8.0 \mathrm{E}-01$ \\
\hline 3 & $1.9 \mathrm{E}-01$ & $1.6 \mathrm{E}-01$ & 8.1E-04 & $8.8 \mathrm{E}-02$ & $9.6 \mathrm{E}-01$ \\
\hline 4 & $2.0 \mathrm{E}-01$ & $1.9 \mathrm{E}-01$ & $8.1 \mathrm{E}-04$ & $1.1 \mathrm{E}-01$ & $1.1 \mathrm{E}+00$ \\
\hline 5 & $2.0 \mathrm{E}-01$ & $2.0 \mathrm{E}-01$ & 8.1E-04 & $1.4 \mathrm{E}-01$ & $1.2 \mathrm{E}+00$ \\
\hline 6 & $2.1 \mathrm{E}-01$ & $2.0 \mathrm{E}-01$ & 8.1E-04 & $1.6 \mathrm{E}-01$ & $1.3 \mathrm{E}+00$ \\
\hline 7 & 2.1E-01 & $2.0 \mathrm{E}-01$ & 8.1E-04 & $1.8 \mathrm{E}-01$ & $1.3 \mathrm{E}+00$ \\
\hline 8 & $2.1 \mathrm{E}-01$ & $2.0 \mathrm{E}-01$ & $8.1 \mathrm{E}-04$ & $2.0 \mathrm{E}-01$ & $1.4 \mathrm{E}+00$ \\
\hline 9 & $2.2 \mathrm{E}-01$ & $2.0 \mathrm{E}-01$ & 8.1E-04 & 2.2E-01 & $1.5 \mathrm{E}+00$ \\
\hline 10 & 2.2E-01 & $2.0 \mathrm{E}-01$ & $8.1 \mathrm{E}-04$ & $2.3 \mathrm{E}-01$ & $1.5 \mathrm{E}+00$ \\
\hline 15 & 2.3E-01 & $2.0 \mathrm{E}-01$ & 8.1E-04 & $2.9 \mathrm{E}-01$ & $1.8 \mathrm{E}+00$ \\
\hline 20 & $2.4 \mathrm{E}-01$ & $2.0 \mathrm{E}-01$ & 8.1E-04 & 3.3E-01 & $2.1 \mathrm{E}+00$ \\
\hline 30 & $2.5 \mathrm{E}-01$ & $2.0 \mathrm{E}-01$ & 8.1E-04 & $3.8 \mathrm{E}-01$ & $2.5 \mathrm{E}+00$ \\
\hline 40 & $2.5 \mathrm{E}-01$ & $2.0 \mathrm{E}-01$ & $8.1 \mathrm{E}-04$ & $4.0 \mathrm{E}-01$ & $2.8 \mathrm{E}+00$ \\
\hline 50 & 2.6E-01 & 2.0E-01 & 8.1E-04 & 4.2E-01 & $3.1 \mathrm{E}+00$ \\
\hline 60 & 2.6E-01 & $2.0 \mathrm{E}-01$ & 8.1E-04 & 4.2E-01 & $3.4 \mathrm{E}+00$ \\
\hline 70 & $2.6 \mathrm{E}-01$ & $2.0 \mathrm{E}-01$ & $8.1 \mathrm{E}-04$ & $4.3 \mathrm{E}-01$ & $3.6 \mathrm{E}+00$ \\
\hline 80 & $2.6 \mathrm{E}-01$ & $2.0 \mathrm{E}-01$ & $8.1 \mathrm{E}-04$ & $4.3 \mathrm{E}-01$ & $3.8 \mathrm{E}+00$ \\
\hline 90 & $2.6 \mathrm{E}-01$ & $2.0 \mathrm{E}-01$ & 8.1E-04 & 4.4E-01 & $4.0 \mathrm{E}+00$ \\
\hline 100 & $2.6 \mathrm{E}-01$ & $2.0 \mathrm{E}-01$ & 8.1E-04 & 4.4E-01 & $4.2 \mathrm{E}+00$ \\
\hline 150 & $2.7 \mathrm{E}-01$ & $2.0 \mathrm{E}-01$ & $8.1 \mathrm{E}-04$ & $4.6 \mathrm{E}-01$ & $5.1 \mathrm{E}+00$ \\
\hline 200 & 2.7E-01 & $2.0 \mathrm{E}-01$ & 8.1E-04 & 4.7E-01 & $5.8 \mathrm{E}+00$ \\
\hline 300 & 2.7E-01 & $2.0 \mathrm{E}-01$ & 8.1E-04 & 4.9E-01 & $7.1 \mathrm{E}+00$ \\
\hline 400 & 2.7E-01 & $2.0 \mathrm{E}-01$ & $8.1 \mathrm{E}-04$ & $5.1 \mathrm{E}-01$ & $8.3 \mathrm{E}+00$ \\
\hline 500 & 2.7E-01 & $2.0 \mathrm{E}-01$ & 8.1E-04 & 5.2E-01 & $9.4 \mathrm{E}+00$ \\
\hline 600 & $2.7 \mathrm{E}-01$ & $2.0 \mathrm{E}-01$ & 8.1E-04 & $5.4 \mathrm{E}-01$ & $1.1 \mathrm{E}+01$ \\
\hline 700 & $2.7 \mathrm{E}-01$ & $2.0 \mathrm{E}-01$ & $8.1 \mathrm{E}-04$ & $5.5 \mathrm{E}-01$ & $1.2 \mathrm{E}+01$ \\
\hline 800 & 2.7E-01 & $2.0 \mathrm{E}-01$ & $8.1 \mathrm{E}-04$ & $5.6 \mathrm{E}-01$ & $1.3 \mathrm{E}+01$ \\
\hline 900 & $2.7 \mathrm{E}-01$ & $2.0 \mathrm{E}-01$ & 8.1E-04 & $5.8 \mathrm{E}-01$ & $1.4 \mathrm{E}+01$ \\
\hline 1000 & 2.7E-01 & $2.0 \mathrm{E}-01$ & $8.1 \mathrm{E}-04$ & $5.9 \mathrm{E}-01$ & $1.5 \mathrm{E}+01$ \\
\hline 1500 & $2.7 \mathrm{E}-01$ & $2.0 \mathrm{E}-01$ & 8.1E-04 & $6.5 \mathrm{E}-01$ & $1.9 \mathrm{E}+01$ \\
\hline 2000 & $2.8 \mathrm{E}-01$ & $2.0 \mathrm{E}-01$ & 8.1E-04 & 7.0E-01 & $2.4 \mathrm{E}+01$ \\
\hline 3000 & $2.8 \mathrm{E}-01$ & 2.0E-01 & 8.1E-04 & 7.7E-01 & $3.1 \mathrm{E}+01$ \\
\hline 4000 & $2.8 \mathrm{E}-01$ & $2.0 \mathrm{E}-01$ & $8.1 \mathrm{E}-04$ & $8.2 \mathrm{E}-01$ & $3.7 \mathrm{E}+01$ \\
\hline 5000 & $2.8 \mathrm{E}-01$ & $2.0 \mathrm{E}-01$ & 8.1E-04 & 8.6E-01 & $4.3 \mathrm{E}+01$ \\
\hline 6000 & $2.8 \mathrm{E}-01$ & $2.0 \mathrm{E}-01$ & 8.1E-04 & $8.9 \mathrm{E}-01$ & $4.7 \mathrm{E}+01$ \\
\hline 7000 & $2.8 \mathrm{E}-01$ & $2.0 \mathrm{E}-01$ & $8.1 \mathrm{E}-04$ & $9.0 \mathrm{E}-01$ & $5.2 \mathrm{E}+01$ \\
\hline 8000 & $2.8 \mathrm{E}-01$ & $2.0 \mathrm{E}-01$ & 8.1E-04 & $9.2 \mathrm{E}-01$ & $5.6 \mathrm{E}+01$ \\
\hline 9000 & $2.8 \mathrm{E}-01$ & $2.0 \mathrm{E}-01$ & 8.1E-04 & $9.2 \mathrm{E}-01$ & $5.9 \mathrm{E}+01$ \\
\hline 10000 & $2.8 \mathrm{E}-01$ & $2.0 \mathrm{E}-01$ & 8.1E-04 & $9.3 \mathrm{E}-01$ & $6.3 \mathrm{E}+01$ \\
\hline
\end{tabular}

${ }^{a} 24-\mathrm{h}$ excretion values for Day 1 after intake refer to cumulative excretion 0-24 h after intake, Day 2 to $24-48 \mathrm{~h}$ after intake, and so forth. Retention values for Day 1 refer to retention at $24 \mathrm{~h}$ after intake, for Day 2 at $48 \mathrm{~h}$, and so forth.

${ }^{b}$ Total content of thoracic compartments shown in Figure 3.1. 
Table 3.11 Model predictions of retention and excretion of uranium (multiple of daily intake) as a function of time after start of continuous inhalation of a moderately soluble form

(Type M, $5 \mu$ m AMAD)

\begin{tabular}{|c|c|c|c|c|c|}
\hline $\begin{array}{c}\text { Days after } \\
\text { start of } \\
\text { intake }^{a} \\
\end{array}$ & $\begin{array}{l}\text { 24-h urinary } \\
\text { excretion }\end{array}$ & $\begin{array}{l}24-h \text { fecal } \\
\text { excretion }\end{array}$ & $\begin{array}{c}\text { Retained in } \\
\text { lungs }^{b}\end{array}$ & $\begin{array}{l}\text { Retained in } \\
\text { kidneys }\end{array}$ & $\begin{array}{c}\text { Retained in } \\
\text { total body }\end{array}$ \\
\hline 1 & $1.8 \mathrm{E}-02$ & $2.2 \mathrm{E}-02$ & $6.1 \mathrm{E}-02$ & $3.6 \mathrm{E}-03$ & $6.6 \mathrm{E}-01$ \\
\hline 2 & $2.4 \mathrm{E}-02$ & $1.8 \mathrm{E}-01$ & $1.2 \mathrm{E}-01$ & 7.5E-03 & $1.0 \mathrm{E}+00$ \\
\hline 3 & $2.5 \mathrm{E}-02$ & $3.1 \mathrm{E}-01$ & $1.7 \mathrm{E}-01$ & $1.1 \mathrm{E}-02$ & $1.2 \mathrm{E}+00$ \\
\hline 4 & $2.6 \mathrm{E}-02$ & 3.7E-01 & 2.3E-01 & $1.5 \mathrm{E}-02$ & $1.3 \mathrm{E}+00$ \\
\hline 5 & 2.6E-02 & $3.8 \mathrm{E}-01$ & $2.8 \mathrm{E}-01$ & $1.8 \mathrm{E}-02$ & $1.4 \mathrm{E}+00$ \\
\hline 6 & $2.7 \mathrm{E}-02$ & 3.9E-01 & 3.3E-01 & $2.1 \mathrm{E}-02$ & $1.4 \mathrm{E}+00$ \\
\hline 7 & $2.8 \mathrm{E}-02$ & $3.9 \mathrm{E}-01$ & 3.9E-01 & $2.3 \mathrm{E}-02$ & $1.5 \mathrm{E}+00$ \\
\hline 8 & $2.8 \mathrm{E}-02$ & $3.9 \mathrm{E}-01$ & $4.4 \mathrm{E}-01$ & $2.6 \mathrm{E}-02$ & $1.5 \mathrm{E}+00$ \\
\hline 9 & $2.9 \mathrm{E}-02$ & $3.9 \mathrm{E}-01$ & $4.9 \mathrm{E}-01$ & $2.8 \mathrm{E}-02$ & $1.6 \mathrm{E}+00$ \\
\hline 10 & 2.9E-02 & $3.9 \mathrm{E}-01$ & $5.4 \mathrm{E}-01$ & $3.0 \mathrm{E}-02$ & $1.7 \mathrm{E}+00$ \\
\hline 15 & $3.2 \mathrm{E}-02$ & $3.9 \mathrm{E}-01$ & 7.8E-01 & $4.0 \mathrm{E}-02$ & $2.0 \mathrm{E}+00$ \\
\hline 20 & $3.4 \mathrm{E}-02$ & $4.0 \mathrm{E}-01$ & $1.0 \mathrm{E}+00$ & 4.6E-02 & $2.2 \mathrm{E}+00$ \\
\hline 30 & $3.7 \mathrm{E}-02$ & $4.0 \mathrm{E}-01$ & $1.4 \mathrm{E}+00$ & $5.5 \mathrm{E}-02$ & $2.7 \mathrm{E}+00$ \\
\hline 40 & $3.9 \mathrm{E}-02$ & 4.0E-01 & $1.8 \mathrm{E}+00$ & $6.1 \mathrm{E}-02$ & $3.1 \mathrm{E}+00$ \\
\hline 50 & $4.1 \mathrm{E}-02$ & $4.0 \mathrm{E}-01$ & $2.1 \mathrm{E}+00$ & $6.5 \mathrm{E}-02$ & $3.5 \mathrm{E}+00$ \\
\hline 60 & 4.3E-02 & 4.0E-01 & $2.4 \mathrm{E}+00$ & 6.9E-02 & $3.9 \mathrm{E}+00$ \\
\hline 70 & $4.5 \mathrm{E}-02$ & 4.1E-01 & $2.7 \mathrm{E}+00$ & 7.2E-02 & $4.2 \mathrm{E}+00$ \\
\hline 80 & 4.6E-02 & $4.1 \mathrm{E}-01$ & $2.9 \mathrm{E}+00$ & 7.5E-02 & $4.5 \mathrm{E}+00$ \\
\hline 90 & 4.7E-02 & $4.1 \mathrm{E}-01$ & $3.1 \mathrm{E}+00$ & 7.7E-02 & $4.7 \mathrm{E}+00$ \\
\hline 100 & 4.9E-02 & 4.1E-01 & $3.3 \mathrm{E}+00$ & $8.0 \mathrm{E}-02$ & $5.0 \mathrm{E}+00$ \\
\hline 150 & $5.3 \mathrm{E}-02$ & 4.1E-01 & $4.2 \mathrm{E}+00$ & 8.9E-02 & $6.1 \mathrm{E}+00$ \\
\hline 200 & 5.7E-02 & 4.1E-01 & $4.8 \mathrm{E}+00$ & 9.7E-02 & $6.9 \mathrm{E}+00$ \\
\hline 300 & $6.1 \mathrm{E}-02$ & $4.1 \mathrm{E}-01$ & $5.6 \mathrm{E}+00$ & $1.1 \mathrm{E}-01$ & $8.0 \mathrm{E}+00$ \\
\hline 400 & $6.4 \mathrm{E}-02$ & $4.1 \mathrm{E}-01$ & $6.1 \mathrm{E}+00$ & $1.2 \mathrm{E}-01$ & $8.8 \mathrm{E}+00$ \\
\hline 500 & $6.5 \mathrm{E}-02$ & 4.1E-01 & $6.3 \mathrm{E}+00$ & $1.2 \mathrm{E}-01$ & $9.3 \mathrm{E}+00$ \\
\hline 600 & $6.6 \mathrm{E}-02$ & $4.1 \mathrm{E}-01$ & $6.4 \mathrm{E}+00$ & $1.3 \mathrm{E}-01$ & $9.7 \mathrm{E}+00$ \\
\hline 700 & $6.6 \mathrm{E}-02$ & $4.1 \mathrm{E}-01$ & $6.5 \mathrm{E}+00$ & $1.3 \mathrm{E}-01$ & $1.0 \mathrm{E}+01$ \\
\hline 800 & $6.6 \mathrm{E}-02$ & $4.1 \mathrm{E}-01$ & $6.6 \mathrm{E}+00$ & $1.3 \mathrm{E}-01$ & $1.0 \mathrm{E}+01$ \\
\hline 900 & 6.7E-02 & 4.1E-01 & $6.6 \mathrm{E}+00$ & $1.4 \mathrm{E}-01$ & $1.1 \mathrm{E}+01$ \\
\hline 1000 & 6.7E-02 & 4.1E-01 & $6.6 \mathrm{E}+00$ & $1.4 \mathrm{E}-01$ & $1.1 \mathrm{E}+01$ \\
\hline 1500 & 6.7E-02 & $4.1 \mathrm{E}-01$ & $6.6 \mathrm{E}+00$ & $1.6 \mathrm{E}-01$ & $1.2 \mathrm{E}+01$ \\
\hline 2000 & $6.7 \mathrm{E}-02$ & $4.1 \mathrm{E}-01$ & $6.6 \mathrm{E}+00$ & $1.7 \mathrm{E}-01$ & $1.3 \mathrm{E}+01$ \\
\hline 3000 & $6.8 \mathrm{E}-02$ & 4.1E-01 & $6.6 \mathrm{E}+00$ & $1.9 \mathrm{E}-01$ & $1.5 \mathrm{E}+01$ \\
\hline 4000 & $6.8 \mathrm{E}-02$ & 4.1E-01 & $6.6 \mathrm{E}+00$ & $2.0 \mathrm{E}-01$ & $1.7 \mathrm{E}+01$ \\
\hline 5000 & $6.8 \mathrm{E}-02$ & $4.1 \mathrm{E}-01$ & $6.6 \mathrm{E}+00$ & $2.1 \mathrm{E}-01$ & $1.8 \mathrm{E}+01$ \\
\hline 6000 & $6.8 \mathrm{E}-02$ & 4.1E-01 & $6.6 \mathrm{E}+00$ & $2.2 \mathrm{E}-01$ & $1.9 \mathrm{E}+01$ \\
\hline 7000 & 6.8E-02 & 4.1E-01 & $6.6 \mathrm{E}+00$ & $2.2 \mathrm{E}-01$ & $2.0 \mathrm{E}+01$ \\
\hline 8000 & $6.8 \mathrm{E}-02$ & 4.1E-01 & $6.6 \mathrm{E}+00$ & $2.2 \mathrm{E}-01$ & $2.1 \mathrm{E}+01$ \\
\hline 9000 & $6.8 \mathrm{E}-02$ & $4.1 \mathrm{E}-01$ & $6.6 \mathrm{E}+00$ & $2.3 \mathrm{E}-01$ & $2.2 \mathrm{E}+01$ \\
\hline 10000 & $6.9 \mathrm{E}-02$ & 4.1E-01 & $6.6 \mathrm{E}+00$ & 2.3E-01 & $2.3 \mathrm{E}+01$ \\
\hline
\end{tabular}

${ }^{a} 24-\mathrm{h}$ excretion values at $1 \mathrm{~d}$ refer to cumulative excretion 0-24 h after start of intake, at $2 \mathrm{~d}$ to $24-48 \mathrm{~h}$ after start of intake, and so forth. Retention values at $1 \mathrm{~d}$ refer to retention at $24 \mathrm{~h}$ after start of intake, at 2 $\mathrm{d}$ to $48 \mathrm{~h}$ after start of intake, and so forth.

${ }^{b}$ Total content of thoracic compartments shown in Figure 3.1. 
Table 3.12 Model predictions of retention and excretion of uranium (multiple of daily intake) as a function of time after start of continuous inhalation of a relatively insoluble form (Type $\mathrm{S}, 5 \mu \mathrm{m}$ AMAD)

\begin{tabular}{|c|c|c|c|c|c|}
\hline $\begin{array}{c}\text { Days after } \\
\text { start of } \\
\text { intake }^{a}\end{array}$ & $\begin{array}{c}\text { 24-h } \\
\text { urinary } \\
\text { excretion }\end{array}$ & $\begin{array}{l}\text { 24-h fecal } \\
\text { excretion }\end{array}$ & $\begin{array}{l}\text { Retained in } \\
\text { lungs }^{b}\end{array}$ & $\begin{array}{l}\text { Retained in } \\
\text { kidneys }\end{array}$ & $\begin{array}{r}\text { Retained in } \\
\text { total body }\end{array}$ \\
\hline 1 & $4.7 \mathrm{E}-04$ & $2.3 \mathrm{E}-02$ & $6.8 \mathrm{E}-02$ & $9.7 \mathrm{E}-05$ & $6.7 \mathrm{E}-01$ \\
\hline 2 & 7.3E-04 & $1.9 \mathrm{E}-01$ & 1.3E-01 & $2.2 \mathrm{E}-04$ & $1.0 \mathrm{E}+00$ \\
\hline 3 & 7.7E-04 & $3.4 \mathrm{E}-01$ & $1.9 \mathrm{E}-01$ & $3.3 \mathrm{E}-04$ & $1.2 \mathrm{E}+00$ \\
\hline 4 & 8.0E-04 & $4.0 \mathrm{E}-01$ & $2.6 \mathrm{E}-01$ & $4.4 \mathrm{E}-04$ & $1.3 \mathrm{E}+00$ \\
\hline 5 & 8.2E-04 & 4.1E-01 & $3.2 \mathrm{E}-01$ & $5.4 \mathrm{E}-04$ & $1.4 \mathrm{E}+00$ \\
\hline 6 & 8.4E-04 & 4.2E-01 & $3.8 \mathrm{E}-01$ & $6.3 \mathrm{E}-04$ & $1.4 \mathrm{E}+00$ \\
\hline 7 & $8.6 \mathrm{E}-04$ & $4.2 \mathrm{E}-01$ & $4.4 \mathrm{E}-01$ & 7.2E-04 & $1.5 \mathrm{E}+00$ \\
\hline 8 & 8.8E-04 & 4.2E-01 & $5.0 \mathrm{E}-01$ & $8.0 \mathrm{E}-04$ & $1.6 \mathrm{E}+00$ \\
\hline 9 & 8.9E-04 & $4.2 \mathrm{E}-01$ & $5.5 \mathrm{E}-01$ & $8.6 \mathrm{E}-04$ & $1.6 \mathrm{E}+00$ \\
\hline 10 & $9.0 \mathrm{E}-04$ & $4.2 \mathrm{E}-01$ & $6.1 \mathrm{E}-01$ & 9.3E-04 & $1.7 \mathrm{E}+00$ \\
\hline 15 & $9.8 \mathrm{E}-04$ & $4.2 \mathrm{E}-01$ & $9.0 \mathrm{E}-01$ & $1.2 \mathrm{E}-03$ & $2.0 \mathrm{E}+00$ \\
\hline 20 & $1.0 \mathrm{E}-03$ & 4.3E-01 & $1.2 \mathrm{E}+00$ & $1.4 \mathrm{E}-03$ & $2.2 \mathrm{E}+00$ \\
\hline 30 & $1.1 \mathrm{E}-03$ & 4.3E-01 & $1.7 \mathrm{E}+00$ & $1.7 \mathrm{E}-03$ & $2.8 \mathrm{E}+00$ \\
\hline 40 & $1.2 \mathrm{E}-03$ & $4.3 \mathrm{E}-01$ & $2.2 \mathrm{E}+00$ & $1.8 \mathrm{E}-03$ & $3.3 \mathrm{E}+00$ \\
\hline 50 & $1.3 \mathrm{E}-03$ & 4.4E-01 & $2.6 \mathrm{E}+00$ & $2.0 \mathrm{E}-03$ & $3.7 \mathrm{E}+00$ \\
\hline 60 & $1.3 \mathrm{E}-03$ & 4.4E-01 & $3.0 \mathrm{E}+00$ & $2.1 \mathrm{E}-03$ & $4.2 \mathrm{E}+00$ \\
\hline 70 & $1.4 \mathrm{E}-03$ & $4.4 \mathrm{E}-01$ & $3.4 \mathrm{E}+00$ & $2.2 \mathrm{E}-03$ & $4.6 \mathrm{E}+00$ \\
\hline 80 & $1.4 \mathrm{E}-03$ & 4.4E-01 & $3.8 \mathrm{E}+00$ & $2.3 \mathrm{E}-03$ & $5.0 \mathrm{E}+00$ \\
\hline 90 & $1.4 \mathrm{E}-03$ & 4.4E-01 & $4.2 \mathrm{E}+00$ & $2.3 \mathrm{E}-03$ & $5.4 \mathrm{E}+00$ \\
\hline 100 & $1.5 \mathrm{E}-03$ & $4.4 \mathrm{E}-01$ & $4.6 \mathrm{E}+00$ & $2.4 \mathrm{E}-03$ & $5.7 \mathrm{E}+00$ \\
\hline 150 & $1.7 \mathrm{E}-03$ & $4.5 \mathrm{E}-01$ & $6.3 \mathrm{E}+00$ & $2.8 \mathrm{E}-03$ & $7.5 \mathrm{E}+00$ \\
\hline 200 & $1.8 \mathrm{E}-03$ & $4.5 \mathrm{E}-01$ & $7.9 \mathrm{E}+00$ & $3.1 \mathrm{E}-03$ & $9.1 \mathrm{E}+00$ \\
\hline 300 & $2.1 \mathrm{E}-03$ & $4.5 \mathrm{E}-01$ & $1.1 \mathrm{E}+01$ & $3.7 \mathrm{E}-03$ & $1.2 \mathrm{E}+01$ \\
\hline 400 & $2.4 \mathrm{E}-03$ & $4.5 \mathrm{E}-01$ & $1.4 \mathrm{E}+01$ & $4.3 \mathrm{E}-03$ & $1.5 \mathrm{E}+01$ \\
\hline 500 & $2.6 \mathrm{E}-03$ & $4.5 \mathrm{E}-01$ & $1.6 \mathrm{E}+01$ & $4.8 \mathrm{E}-03$ & $1.7 \mathrm{E}+01$ \\
\hline 600 & $2.9 \mathrm{E}-03$ & 4.6E-01 & $1.8 \mathrm{E}+01$ & $5.4 \mathrm{E}-03$ & $2.0 \mathrm{E}+01$ \\
\hline 700 & $3.1 \mathrm{E}-03$ & 4.6E-01 & $2.0 \mathrm{E}+01$ & $5.9 \mathrm{E}-03$ & $2.2 \mathrm{E}+01$ \\
\hline 800 & $3.3 \mathrm{E}-03$ & 4.6E-01 & $2.2 \mathrm{E}+01$ & $6.3 \mathrm{E}-03$ & $2.4 \mathrm{E}+01$ \\
\hline 900 & $3.4 \mathrm{E}-03$ & $4.6 \mathrm{E}-01$ & $2.4 \mathrm{E}+01$ & $6.8 \mathrm{E}-03$ & $2.5 \mathrm{E}+01$ \\
\hline 1000 & $3.6 \mathrm{E}-03$ & $4.6 \mathrm{E}-01$ & $2.6 \mathrm{E}+01$ & $7.2 \mathrm{E}-03$ & $2.7 \mathrm{E}+01$ \\
\hline 1500 & $4.2 \mathrm{E}-03$ & 4.7E-01 & $3.2 \mathrm{E}+01$ & $9.2 \mathrm{E}-03$ & $3.3 \mathrm{E}+01$ \\
\hline 2000 & 4.7E-03 & $4.7 \mathrm{E}-01$ & $3.6 \mathrm{E}+01$ & $1.1 \mathrm{E}-02$ & $3.8 \mathrm{E}+01$ \\
\hline 3000 & $5.3 \mathrm{E}-03$ & 4.7E-01 & $4.2 \mathrm{E}+01$ & $1.4 \mathrm{E}-02$ & $4.4 \mathrm{E}+01$ \\
\hline 4000 & $5.6 \mathrm{E}-03$ & 4.7E-01 & $4.5 \mathrm{E}+01$ & $1.6 \mathrm{E}-02$ & $4.8 \mathrm{E}+01$ \\
\hline 5000 & $5.9 \mathrm{E}-03$ & 4.7E-01 & $4.8 \mathrm{E}+01$ & $1.7 \mathrm{E}-02$ & $5.0 \mathrm{E}+01$ \\
\hline 6000 & $6.1 \mathrm{E}-03$ & 4.7E-01 & $5.0 \mathrm{E}+01$ & $1.8 \mathrm{E}-02$ & $5.3 \mathrm{E}+01$ \\
\hline 7000 & $6.3 \mathrm{E}-03$ & 4.7E-01 & $5.1 \mathrm{E}+01$ & $1.9 \mathrm{E}-02$ & $5.5 \mathrm{E}+01$ \\
\hline 8000 & $6.5 \mathrm{E}-03$ & $4.7 \mathrm{E}-01$ & $5.3 \mathrm{E}+01$ & $2.0 \mathrm{E}-02$ & $5.6 \mathrm{E}+01$ \\
\hline 9000 & $6.6 \mathrm{E}-03$ & 4.7E-01 & $5.4 \mathrm{E}+01$ & $2.1 \mathrm{E}-02$ & $5.8 \mathrm{E}+01$ \\
\hline 10000 & 6.7E-03 & 4.7E-01 & $5.5 \mathrm{E}+01$ & $2.2 \mathrm{E}-02$ & $5.9 \mathrm{E}+01$ \\
\hline
\end{tabular}

${ }^{a} 24-\mathrm{h}$ excretion values at $1 \mathrm{~d}$ refer to cumulative excretion $0-24 \mathrm{~h}$ after start of intake, at $2 \mathrm{~d}$ to $24-48$ $\mathrm{h}$ after start of intake, and so forth. Retention values at $1 \mathrm{~d}$ refer to retention at $24 \mathrm{~h}$ after start of intake, at $2 \mathrm{~d}$ to $48 \mathrm{~h}$ after start of intake, and so forth.

${ }^{b}$ Total content of thoracic compartments shown in Figure 3.1. 


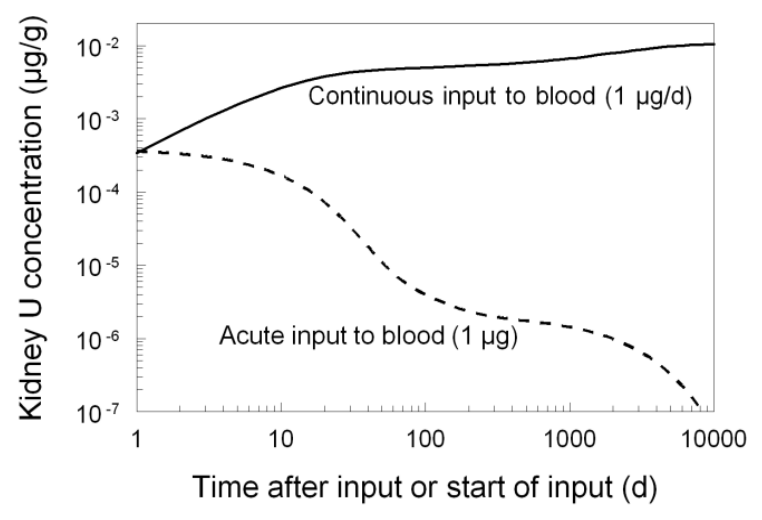

Figure 3.9 Model predictions of the time-dependent concentration of uranium in the kidneys, assuming either acute input of $1 \mu \mathrm{g}$ to blood at time zero or continuous input to blood at the rate $1 \mu \mathrm{g} / \mathrm{d}$.

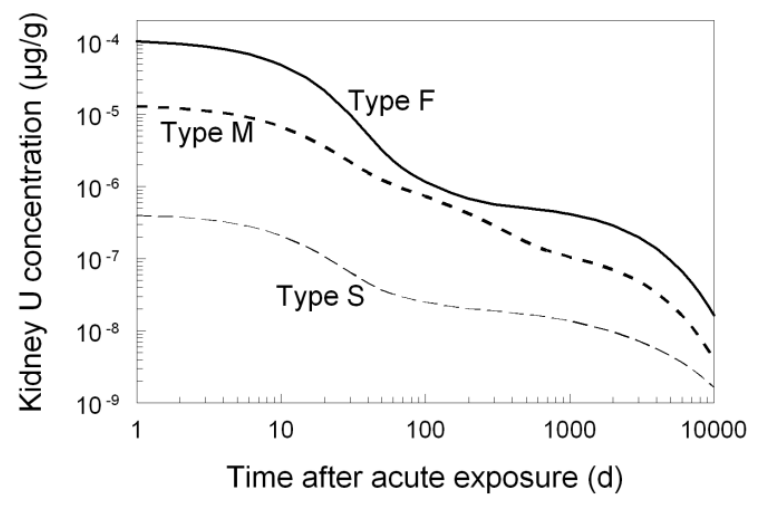

Figure 3.10 Model predictions of the concentration of uranium in the kidneys as a function of time after acute inhalation of $1 \mu \mathrm{g}$ of uranium of Type F, Type M, or Type $S$ ( $5 \mu \mathrm{m}$ AMAD). 


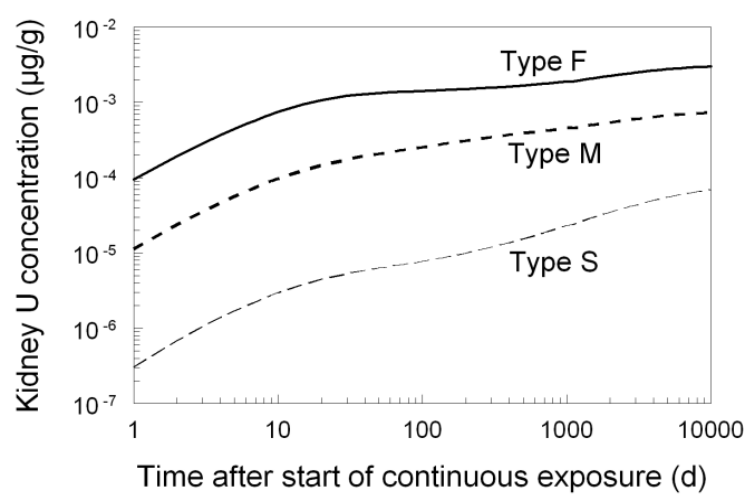

Figure 3.11 Model predictions of the concentration of uranium in the kidneys as a function of time after start of continuous inhalation of uranium of Type F, Type M, or Type $S$ (5 $\mu$ m AMAD) at the rate $1 \mu \mathrm{g} / \mathrm{d}$.

Model predictions of the concentration ratio R of uranium in kidneys ( $\mu \mathrm{g}$ U/g kidney) to uranium in urine ( $\mu \mathrm{g} \mathrm{U} / \mathrm{mL}$ urine) are listed in Table 3.13 for acute inhalation of uranium; predictions are shown graphically in Figure 3.12. The ratio $\mathrm{R}$ is higher for Type $\mathrm{F}$ than for Type M or Type S, which differ only slightly from one another. 
Table 3.13 Model predictions of kidney to urine concentration ratio as a function of time following acute inhalation ${ }^{b}$ of uranium by a worker (particle size $=5 \mu \mathrm{m}$ AMAD)

\begin{tabular}{|c|c|c|c|}
\hline \multirow{2}{*}{$\begin{array}{l}\text { Time after } \\
\text { exposure }^{a} \\
\text { (d) }\end{array}$} & \multicolumn{3}{|c|}{$\begin{array}{c}\text { Concentration ratio } \\
\text { Kidney } U(\mu \mathrm{g} / \mathrm{g}): \text { Urinary } U(\mu \mathrm{g} / \mathrm{mL})\end{array}$} \\
\hline & Type $^{b}$ & Туре M & Type S \\
\hline 1 & 16 & 10 & 5.7 \\
\hline 2 & 28 & 22 & 22 \\
\hline 3 & 29 & 22 & 23 \\
\hline 4 & 29 & 22 & 23 \\
\hline 5 & 29 & 22 & 23 \\
\hline 6 & 30 & 22 & 23 \\
\hline 7 & 30 & 22 & 23 \\
\hline 8 & 30 & 21 & 22 \\
\hline 9 & 30 & 21 & 22 \\
\hline 10 & 30 & 21 & 22 \\
\hline 15 & 29 & 19 & 20 \\
\hline 20 & 28 & 17 & 17 \\
\hline 30 & 24 & 14 & 14 \\
\hline 40 & 20 & 12 & 12 \\
\hline 50 & 17 & 11 & 11 \\
\hline 60 & 16 & 10 & 10 \\
\hline 70 & 16 & 10 & 10 \\
\hline 80 & 17 & 10 & 10 \\
\hline 90 & 18 & 10 & 10 \\
\hline 100 & $\mathrm{C}$ & 10 & 10 \\
\hline 110 & $\mathrm{C}$ & 11 & 10 \\
\hline 120 & $\mathrm{C}$ & 11 & 10 \\
\hline 130 & $\mathrm{C}$ & 11 & 10 \\
\hline 140 & $\mathrm{C}$ & 11 & 10 \\
\hline 150 & $\mathrm{C}$ & 11 & 10 \\
\hline 175 & $\mathrm{C}$ & 12 & 10 \\
\hline 200 & $\mathrm{C}$ & 12 & 10 \\
\hline 225 & $\mathrm{C}$ & 13 & 10 \\
\hline 250 & $\mathrm{C}$ & 13 & 11 \\
\hline 275 & $\mathrm{C}$ & 14 & 11 \\
\hline 300 & $\mathrm{C}$ & 15 & 11 \\
\hline 325 & $\mathrm{C}$ & 16 & 11 \\
\hline 365 & $\mathrm{C}$ & 18 & 11 \\
\hline
\end{tabular}

${ }^{a}$ Day 1 refers to ratio at $24 \mathrm{~h}$ after exposure, Day 2 at $48 \mathrm{~h}$ after exposure, and so forth.

${ }^{b}$ Ratios for Type $\mathrm{F}$ are applicable to intravenous injection of uranium and, for Day 2 and beyond, to ingestion of uranium.

${ }^{c}$ Projected ratios for acute intake of soluble material may involve large errors beyond 3 mo after intake because urine levels would have declined by several orders of magnitude by this time. 


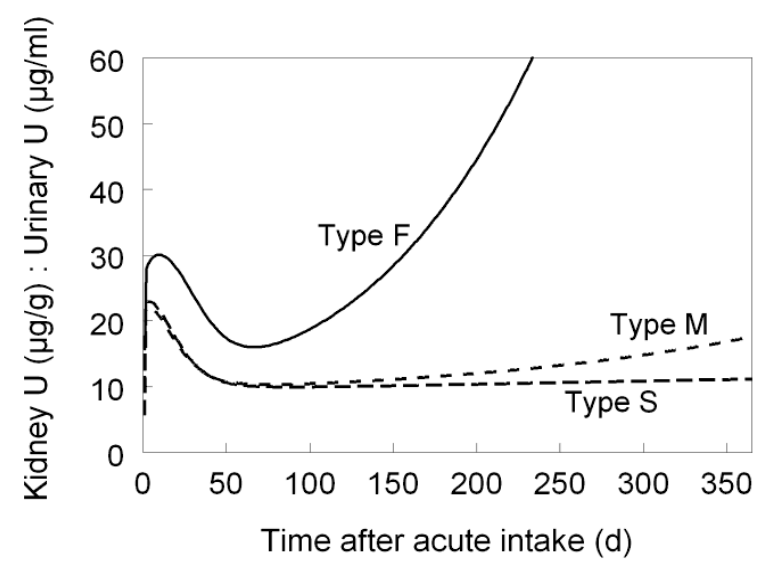

Figure 3.12 Model predictions of the concentration ratio of uranium in kidneys $(\mu \mathrm{g} / \mathrm{g})$ to uranium in urine $(\mu \mathrm{g} / \mathrm{mL})$ as a function of time after acute inhalation of uranium (particle size $5 \mu \mathrm{m}$ AMAD).

Model predictions of the concentration ratio $\mathrm{R}$ of uranium in kidneys to uranium in urine are listed in Table 3.14 for continuous intake of uranium; predictions are shown graphically in Figure 3.13. For all practical purposes the same curve may be applied to inhalation of any of the default absorption types, ingestion, or direct input into blood, provided the intake rate remains constant. 
Table 3.14 Model predictions of kidney to urine concentration ratio as a function of time after the start of continuous intake of uranium at a constant rate by inhalation, ingestion, or direct input into blood

\begin{tabular}{|c|c|}
\hline $\begin{array}{l}\text { Time after } \\
\text { exposure }^{a} \\
\text { (d) }\end{array}$ & $\begin{array}{c}\text { Concentration ratio }^{b} \\
\text { Kidney } U(\mu \mathrm{g} / \mathrm{g}): \text { Urinary } U \\
(\mu \mathrm{g} / \mathrm{mL})\end{array}$ \\
\hline 1 & 0.8 \\
\hline 2 & 1.6 \\
\hline 3 & 2.3 \\
\hline 4 & 2.9 \\
\hline 5 & 3.5 \\
\hline 6 & 4.0 \\
\hline 7 & 4.4 \\
\hline 8 & 4.8 \\
\hline 9 & 5.2 \\
\hline 10 & 5.5 \\
\hline 15 & 6.6 \\
\hline 20 & 7.2 \\
\hline 30 & 7.9 \\
\hline 40 & 8.2 \\
\hline 50 & 8.4 \\
\hline 70 & 8.5 \\
\hline 100 & 8.6 \\
\hline 200 & 9.0 \\
\hline 300 & 9.3 \\
\hline 400 & 9.6 \\
\hline 500 & 9.9 \\
\hline 700 & 10 \\
\hline 1000 & 11 \\
\hline 2000 & 13 \\
\hline 3000 & 14 \\
\hline 4000 & 15 \\
\hline 5000 & 16 \\
\hline 7000 & 17 \\
\hline 10000 & 17 \\
\hline
\end{tabular}

${ }^{a}$ Day 1 refers to ratio at $24 \mathrm{~h}$ after start of exposure, Day 2 at $48 \mathrm{~h}$ after start of exposure, and so forth.

${ }^{b}$ Values derived for inhalation of relatively soluble (Type F) material but model estimates are not sensitive to absorption type or mode of intake provided rate of uptake to blood remains nearly constant. 


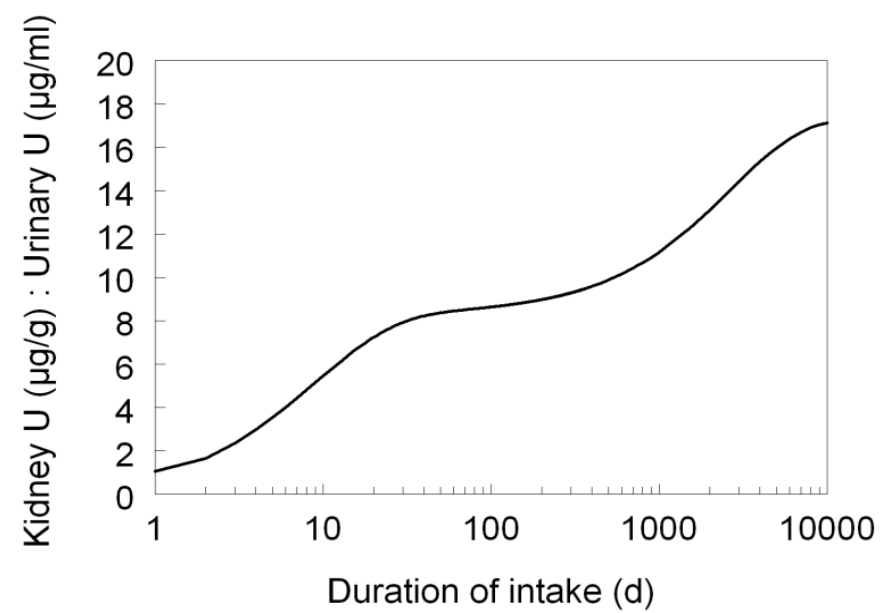

Figure 3.13 Model predictions of the concentration ratio of uranium in kidneys $(\mu \mathrm{g} / \mathrm{g})$ to uranium in urine $(\mu \mathrm{g} / \mathrm{mL})$ as a function of duration of continuous inhalation of uranium at a constant rate. The curve applies to any absorption type (particle size $5 \mu \mathrm{m}$ AMAD).

\subsection{Estimates of Effective Dose Per Unit Intake of Natural Uranium Isotopes}

Determination of compliance with radiation reference guidance levels for uranium requires application of effective dose coefficients for each of the major uranium isotopes. Effective dose coefficients for ${ }^{234} \mathrm{U},{ }^{235} \mathrm{U}$, and ${ }^{238} \mathrm{U}$ are given in Table 3.15 for the case of intravenous injection and in Table 3.16 for inhalation of relatively soluble (Type F), moderately soluble (Type $\mathrm{M}$ ), or relatively insoluble (Type $\mathrm{S}$ ) forms of uranium. For the inhalation cases the assumed particle size is $5 \mu \mathrm{m}$ AMAD. The effective dose coefficients for intravenous injection might be applied, for example, to the case of a puncture wound contaminated with a relatively soluble form of uranium.

The dose coefficients listed in Tables 3.15 and 3.16 were initially derived in terms of dose per unit activity $(\mathrm{Sv} / \mathrm{Bq})$. Conversion to dose per unit mass was based on the specific activities of ${ }^{234} \mathrm{U},{ }^{235} \mathrm{U}$, and ${ }^{238} \mathrm{U}$ listed in Table 3.17. Coefficients given in terms of dose per unit mass may be used to compare derived reference guidance for exposure to uranium based on radiological reference guidance to reference guidance based on uranium as a chemical hazard. 
Table 3.15 Effective dose coefficients for intravenously injected $U$ isotopes

\begin{tabular}{ccc}
\hline \multirow{2}{*}{ U isotope } & \multicolumn{2}{c}{ Effective dose coefficient } \\
\cline { 2 - 3 } Sv/g \\
\hline${ }^{234} \mathrm{U} / \mathbf{B q}$ & $5.3 \times 10^{2}$ \\
${ }^{235} \mathrm{U}$ & $2.3 \times 10^{-6}$ & $1.7 \times 10^{-1}$ \\
${ }^{238} \mathrm{U}$ & $2.1 \times 10^{-6}$ & $2.6 \times 10^{-2}$ \\
\hline
\end{tabular}

Table 3.16 Effective dose coefficients for inhalation of uranium isotopes of Type F, M, or S (5 $\mu \mathrm{m}$ AMAD)

\begin{tabular}{cccc}
\hline Type & U isotope & $\mathbf{E}(\mathbf{S v} / \mathbf{B q})$ & $\mathbf{E}(\mathbf{S v} / \mathbf{g ~ U})$ \\
\hline $\mathrm{F}$ & ${ }^{234} \mathrm{U}$ & $6.4 \times 10^{-7}$ & $1.5 \times 10^{2}$ \\
& ${ }^{235} \mathrm{U}$ & $6.0 \times 10^{-7}$ & $4.8 \times 10^{-2}$ \\
& ${ }^{238} \mathrm{U}$ & $5.8 \times 10^{-7}$ & $7.3 \times 10^{-3}$ \\
$\mathrm{M}$ & ${ }^{234} \mathrm{U}$ & $2.1 \times 10^{-6}$ & $4.9 \times 10^{2}$ \\
& ${ }^{235} \mathrm{U}$ & $1.8 \times 10^{-6}$ & $1.4 \times 10^{-1}$ \\
& ${ }^{238} \mathrm{U}$ & $1.6 \times 10^{-6}$ & $2.0 \times 10^{-2}$ \\
$\mathrm{~S}$ & ${ }^{234} \mathrm{U}$ & $6.8 \times 10^{-6}$ & $1.6 \times 10^{3}$ \\
& ${ }^{235} \mathrm{U}$ & $6.1 \times 10^{-6}$ & $4.9 \times 10^{-1}$ \\
& ${ }^{238} \mathrm{U}$ & $5.7 \times 10^{-6}$ & $7.1 \times 10^{-2}$ \\
\hline
\end{tabular}

Table 3.17 Specific activities of $U$ isotopes

\begin{tabular}{cc}
\hline U isotope & $\begin{array}{c}\text { Specific activity } \\
(\mathbf{B q} / \mathbf{g})\end{array}$ \\
\hline${ }^{234} \mathrm{U}$ & $2.32 \times 10^{8}$ \\
${ }^{235} \mathrm{U}$ & $8.01 \times 10^{4}$ \\
${ }^{238} \mathrm{U}$ & $1.25 \times 10^{4}$ \\
\hline
\end{tabular}




\section{VARIATION WITH TIME IN URINARY URANIUM: A COMPLICATING FACTOR IN INTERPRETATION OF URINE MEASUREMENTS}

Uranium has a high rate of renal clearance. According to the systemic model for uranium described in Section 3, about two-thirds of uranium atoms entering blood at time zero are excreted in urine during the first $24 \mathrm{~h}$. Because of its high rate of clearance in urine, the concentration of uranium in a urine sample collected during work hours may be dominated by intake occurring earlier in the day. This is illustrated by the following hypothetical chronic exposure case involving idealized conditions designed for computational and expository convenience. It is assumed in this example that the biokinetic models described in Section 3 are reasonably accurate predictors of the rate of urinary excretion of inhaled uranium.

Example 4.1. A person with no previous occupational exposure to uranium begins work at a uranium mill. The work schedule is 8 am to 4 pm, Monday through Friday. (Greater detail such as removal from exposure during lunch and breaks would not be useful for purposes of this illustration.) The worker is exposed daily to a moderately soluble form (Type M) of airborne uranium of particle size $5 \mu \mathrm{m}$ AMAD. The concentration of airborne uranium in the work area is constant during each workday but varies from one day to the next. Weekly intake is $55 \mu \mathrm{g}$ over each of the first three weeks. During the fourth week the ordered daily intakes are $20,12,6,2$, and $15 \mu \mathrm{g} \mathrm{U}$, again giving a total intake of $55 \mu \mathrm{g}$ for the week. The rate of urinary excretion of uranium over a 7-day period starting at 8 am on Monday of the fourth week, as predicted by the models in Section 3 with the daily intakes described above as model input (assuming a constant intake rate during each 8 -h work period), are shown in Figure 4.1. The urinary excretion rate rises sharply during work hours. During the workweek the rate of urinary excretion is influenced considerably more by exposure during that week than by cumulative exposure over the 4-week period. A measurement of the urinary excretion rate during work hours in the fourth week would not be a useful indicator of the cumulative exposure over the 4-week period unless the urine sample was collected at the start of the workday. The best sampling period with regard to minimizing the influence of very recent exposure would be on Monday morning before the start of work, after removal from exposure for about 64 hours.

To back-calculate intake of uranium on the basis of urinary uranium, one must start with a known or assumed pattern of exposure. If exposures are spread out over time it usually suffices to assume either a constant intake rate during work hours or, to simplify calculations, continuous exposure at a constant rate during the exposure period with no allowance for time away from work. This is illustrated by the following hypothetical one-week exposure case. 


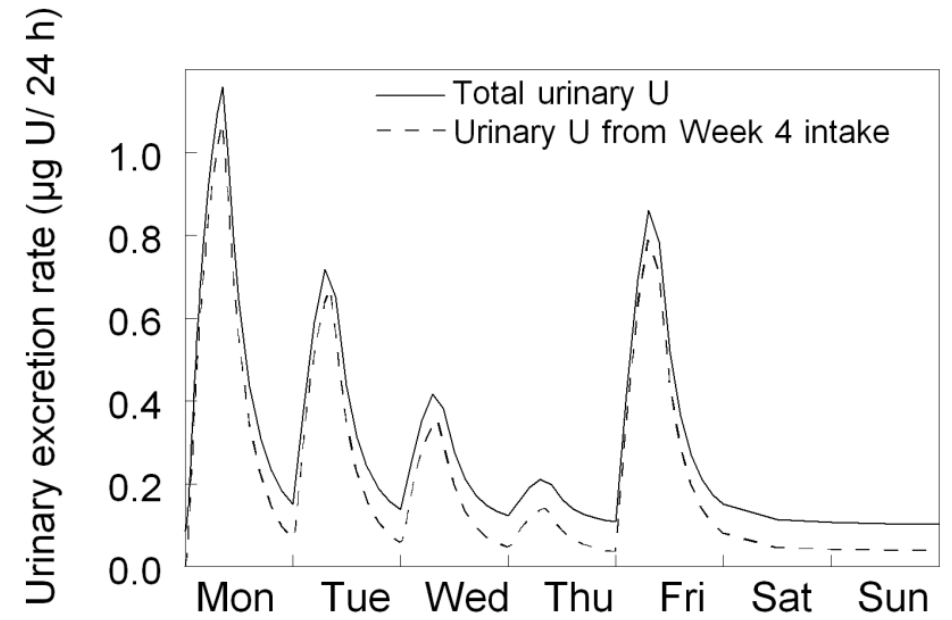

Figure 4.1 For the hypothetical case described in Example 4.1, model predictions of the urinary excretion rate (rate of entry of uranium into the urinary bladder contents) during Week 4. Urinary U during most work hours in Week 4 results primarily from same-day intake and is only a weak reflection of cumulative intake since the start of exposure.

Example 4.2. A person with no previous occupational exposure to uranium begins work at a uranium mill. Measured air concentrations of uranium in his work area during the first week average $4.0 \mu \mathrm{g} / \mathrm{m}^{3}$ on Monday, $2.4 \mu \mathrm{g} / \mathrm{m}^{3}$ on Tuesday, $1.2 \mu \mathrm{g} / \mathrm{m}^{3}$ on Wednesday, $0.4 \mu \mathrm{g} / \mathrm{m}^{3}$ on Thursday, and $3.0 \mu \mathrm{g} / \mathrm{m}^{3}$ on Friday. A urine sample collected the following Monday morning before the start of work shows an excretion rate of $0.039 \mu \mathrm{g} \mathrm{U} / \mathrm{d}$ when extrapolated to a daily urine volume of $1600 \mathrm{~mL}$ (reference value for an adult male given in ICRP Publication 89, 2002). A site health physicist (HP) uses the biokinetic models described in Section 3 to back-calculate the worker's total intake the preceding week based on the urinalysis. The HP assumes the worker was exposed to Type M material of particle size 5 $\mu \mathrm{m}$ AMAD based on recent measurements of solubility and particle size of airborne material in the building. The HP makes three estimates of total intake based on three different assumptions concerning the pattern of intake:

Case (a) - The rate of intake each day was proportional to the average concentration of uranium in air in the building that day.

Case (b) - Intake occurred at a constant rate during the 40 work hours.

Case (c) - Intake occurred at a constant rate from 8 am on Monday to 4 pm on Friday including hours away from work (104 hours elapsed time).

Back-calculations of uranium intake are made as follows. In Case (a) it is assumed that there was a unit intake $(1 \mu \mathrm{g})$ on Monday. Because daily intakes are assumed to be proportional to the average air concentration of uranium in the building, assumed intakes are $1 \mu \mathrm{g} \times 2.4 / 4.0=$ $0.6 \mu \mathrm{g}$ on Tuesday, $1 \mu \mathrm{g} \times 1.2 / 4.0=0.3 \mu \mathrm{g}$ on Wednesday, $1 \mu \mathrm{g} \times 0.4 / 4.0=0.1 \mu \mathrm{g}$ on Thursday, and $1 \mu \mathrm{g} \times 3.0 / 4.0=0.75 \mu \mathrm{g}$ on Friday. With these intakes as model input, the models in Section 3 predict a urinary excretion rate of $0.00196 \mu \mathrm{g} / \mathrm{d}$ at $8 \mathrm{am}$ on Monday morning. Because the observed urinary excretion rate is $0.039 \mu \mathrm{g} / \mathrm{d}$, the intakes used as model input must be increased by a factor of $0.039 / 0.00196=19.90$ to reproduce the observed excretion rate. Therefore, based on the exposure pattern assumed in Case (a), the 
estimated total intake is $19.90 \times(1.0+0.6+0.3+0.1+0.75) \mu \mathrm{g}=54.7 \mu \mathrm{g}$. In Case (b) it is assumed that intake was $1 \mu \mathrm{g}$ each 8 -h workday. With this intake rate used as model input, the models predict a urinary excretion rate of $0.00363 \mu \mathrm{g} / \mathrm{d}$ at $8 \mathrm{am}$ on Monday morning. Because the observed urinary excretion rate is $0.039 \mu \mathrm{g} / \mathrm{d}$, the intake rate used as model input must be increased by a factor of $0.039 / 0.00363=10.74$ to reproduce the observed excretion rate. Therefore, based on the exposure pattern assumed in Case (b), the estimated intake is $10.74 \times(1.0+1.0+1.0+1.0+1.0) \mu \mathrm{g}=53.7 \mu \mathrm{g}$. In Case (c) it is assumed that intake was $1 \mu \mathrm{g}$ each $24-h$ period. With this intake rate used as input, the models predict a urinary excretion rate of $0.00313 \mu \mathrm{g} / \mathrm{d}$ at 8 am on Monday morning. Because the observed urinary excretion rate is $0.039 \mu \mathrm{g} / \mathrm{d}$, the intake rate used as model input must be increased by a factor of $0.039 / 0.00313=12.46$ to reproduce the observed excretion rate. Therefore, based on the exposure pattern assumed in Case (c), the estimated intake is $12.46 \times(104 \mathrm{~h} \times 1 \mu \mathrm{g} / 24 \mathrm{~h})=$ $54.0 \mu \mathrm{g}$. The results of the analysis, including the predicted concentration of uranium in the kidneys at 8 am on Monday morning, are summarized in Table 4.1. The three different patterns of assumed intake yield essentially the same estimates of total intake (and hence effective dose) and kidney concentration of uranium. In this example, the estimate of total intake of uranium for the week and the concentration of uranium in the kidney are insensitive to the assumed temporal pattern of intake during the week, provided urinary uranium is measured after the rapidly excreted portion of the uranium intake has been eliminated.

Table 4.1 Model predictions of total uranium intake based on urinary uranium measurement after weekend and alternate assumed patterns of exposure (see Example 4.2)

\begin{tabular}{|c|c|c|}
\hline Assumed exposure pattern & $\begin{array}{l}\text { Estimated } \\
\text { total intake } \\
\quad(\mu \mathrm{g} U)\end{array}$ & $\begin{array}{c}\text { Model prediction of kidney } U \\
\text { concentration at time of urine } \\
\text { measurement } \\
(\mu \mathrm{g} U / \mathrm{g} \text { kidney })\end{array}$ \\
\hline $\begin{array}{l}\text { Proportional to average concentration of } \\
\text { uranium in air in building }\end{array}$ & 54.7 & 0.00054 \\
\hline Constant intake rate during work hours & 53.7 & 0.00054 \\
\hline $\begin{array}{l}\text { Constant, continuous intake } \\
\text { (including non-work hours) } \\
\text { Monday, } 8 \text { am - Friday, } 4 \text { pm }\end{array}$ & 54.0 & 0.00054 \\
\hline
\end{tabular}

The following examples are based on the idealized situation in which the concentration of uranium in air in the workplace is constant and the worker is exposed to the contaminated atmosphere for 8 hours a day, five days a week.

The strong dependence of the measured concentration of uranium in urine on the time of measurement is illustrated in Figures 4.2-4.4 for different forms of inhaled uranium. Also shown in these figures is the projected change in the concentration of uranium in the kidneys over the same period of exposure. Model predictions are for inhalation of uranium of Type F (Figure 4.2), Type M (Figure 4.3), or Type S (Figure 4.4) with a particle size of $5 \mu \mathrm{m}$ AMAD. Model 
predictions are based on an assumed total weekly intake of $1 \mathrm{mg} \mathrm{U}$ starting about $2 \mathrm{mo}$ (precisely, 9 full weeks or 63 days) before the first time shown. Two different patterns of exposure are addressed in each of these figures: continuous inhalation at a constant rate (dashed curves); and intake at a constant rate during work hours of 8 am to $4 \mathrm{pm}$, Monday through Friday (solid curves). Compared with the urinary excretion rate based on continuous intake, the rate based on intake during work hours only is about 3 times higher at the end of a work shift and one-fourth to one-third times as high at the beginning of the next work shift. According to the model, the concentration of uranium in the kidneys changes relatively slowly with time, and the concentration resulting from intermittent intake can be approximated reasonably well as a continuous exposure based on the same weekly intake.
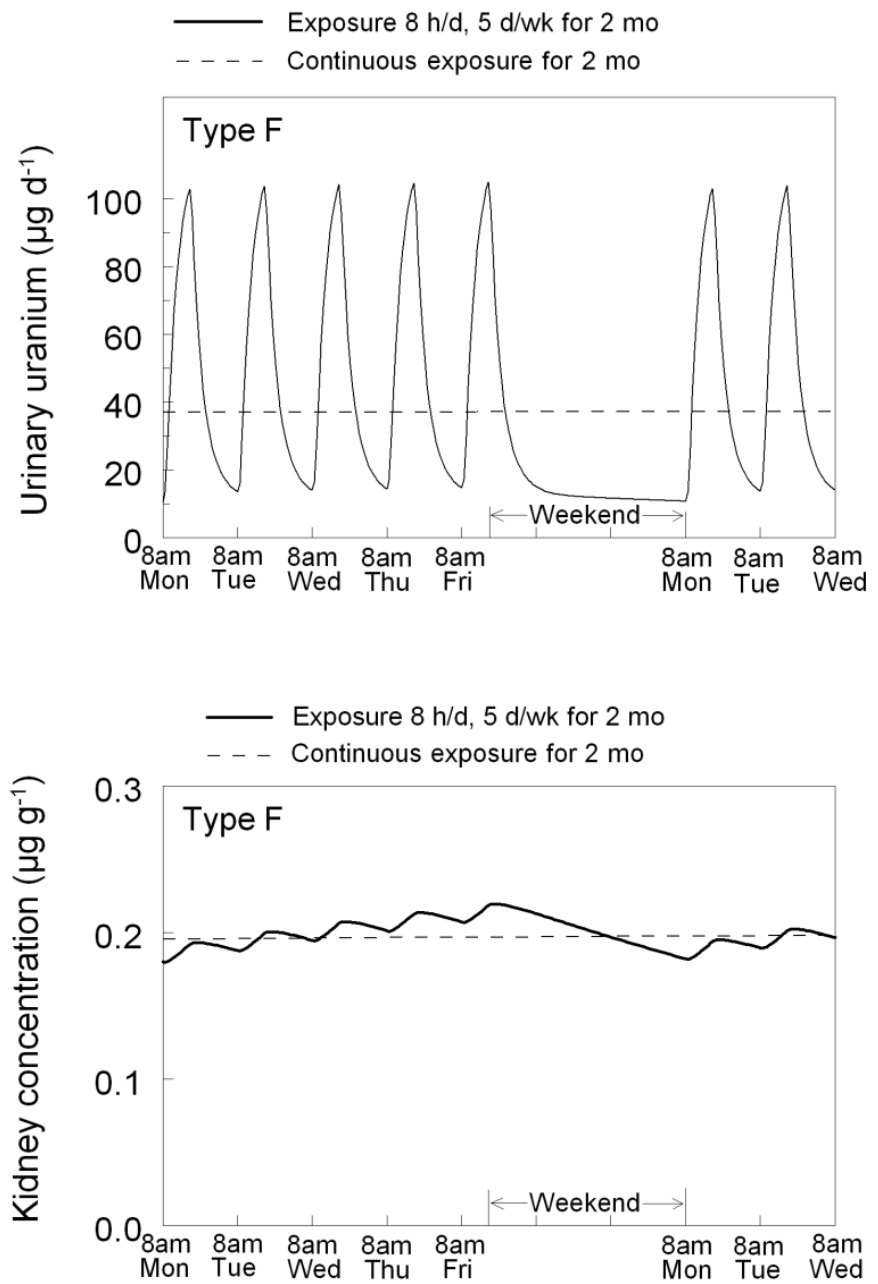

Figure 4.2 For inhalation of a relatively soluble form of uranium (Type F, $5 \mu \mathrm{m}$ AMAD; intake $=1 \mathrm{mg} / \mathrm{wk}$ ), projected urinary excretion rate (top panel) and concentration of uranium in kidneys (bottom panel) for different patterns of exposure: continuous intake at a constant rate (dashed curve) or inhalation at a constant rate during regular work hours (solid curve). It is assumed that exposure began 9 wk before earliest time shown. 

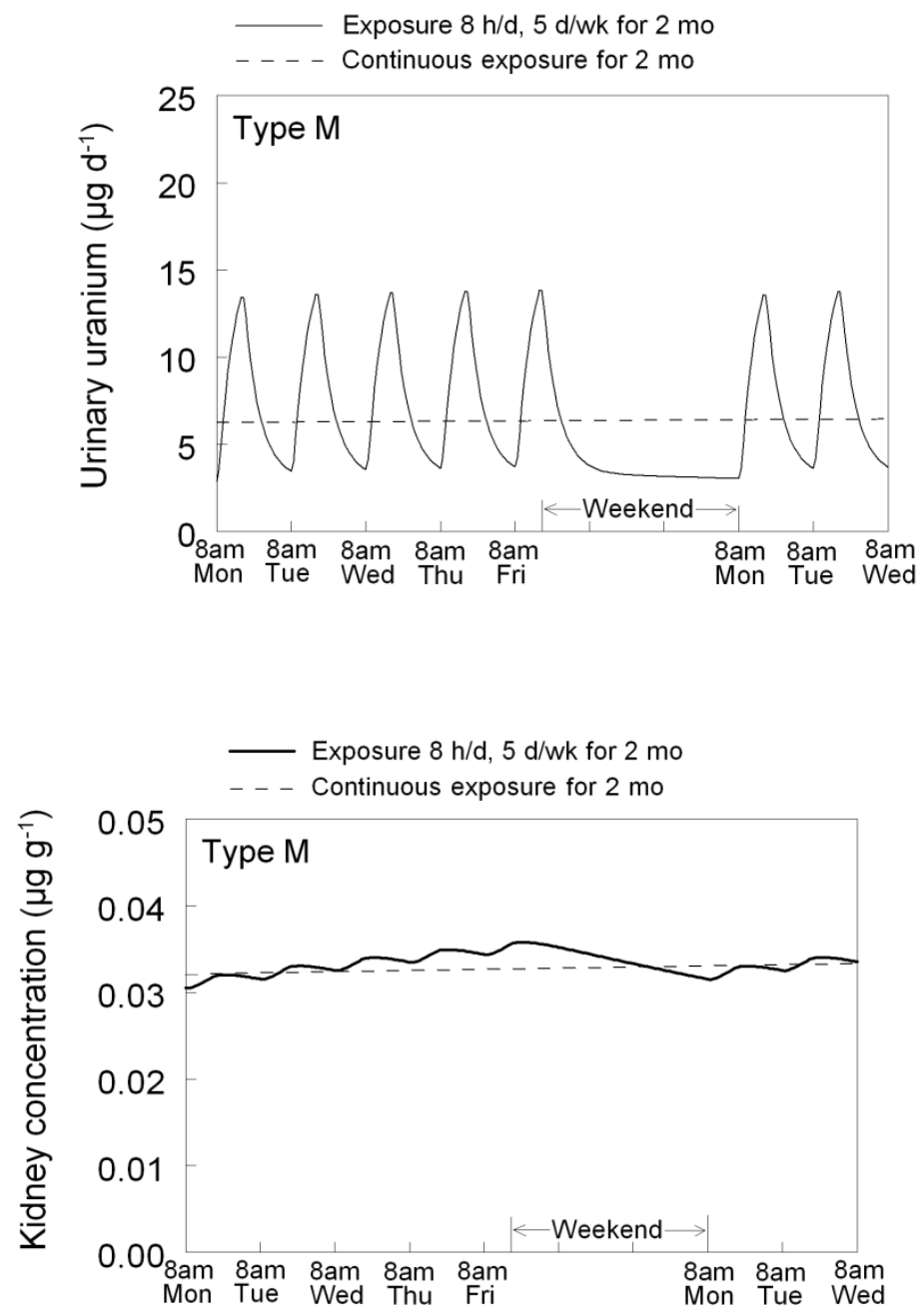

Figure 4.3 For inhalation of a moderately soluble form of uranium (Type M, $5 \mu$ m AMAD; intake $=1 \mathrm{mg} / \mathrm{wk}$ ), projected urinary excretion rate (top panel) and concentration of uranium in kidneys (bottom panel) for different patterns of exposure: continuous intake at a constant rate (dashed curve) or inhalation at a constant rate during regular work hours (solid curve). It is assumed that exposure began 9 wk before earliest time shown. 

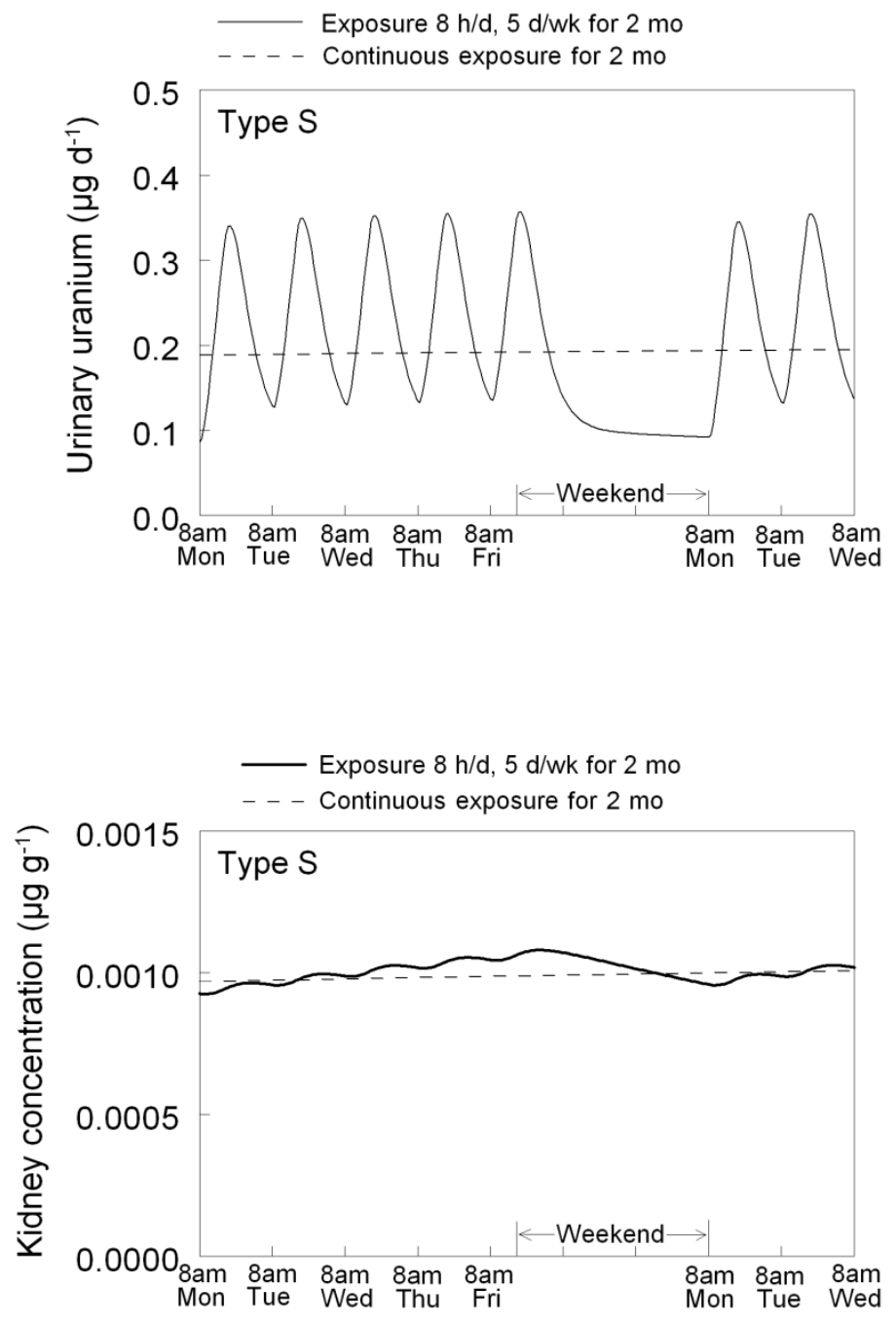

Figure 4.4 For inhalation of a relatively insoluble form of uranium (Type $S, 5 \mu \mathrm{m}$ AMAD; intake $=1 \mathrm{mg} / \mathrm{wk}$ ), projected urinary excretion rate (top panel) and concentration of uranium in kidneys (bottom panel) for different patterns of exposure: continuous intake at a constant rate (dashed curve) or inhalation at a constant rate during regular work hours (solid curve). It is assumed that exposure began 9 wk before earliest time shown.

As illustrated in Figure 4.5, rapid increases and declines in the urinary excretion rate of uranium due to discontinuities in exposure is expected to occur even after exposure to uranium for several years. As in Figures 4.2-4.4, two different patterns of exposure are addressed in Figure 4.5: continuous inhalation at a constant rate (dashed curves); and intake at a constant rate during work hours of 8 am to $4 \mathrm{pm}$, Monday through Friday (solid curves). Again, weekly intake of uranium is assumed to be $1 \mathrm{mg}$, but in this case the exposure is assumed to have started five years before the times depicted in the figure. After this length of time the contribution of recently absorbed uranium to urinary uranium has declined slightly due to buildup of uranium in skeleton and other tissues and release from these tissues to blood; however, recently absorbed 
uranium still represents a substantial portion of the total excreted in urine, particularly for Type F material.
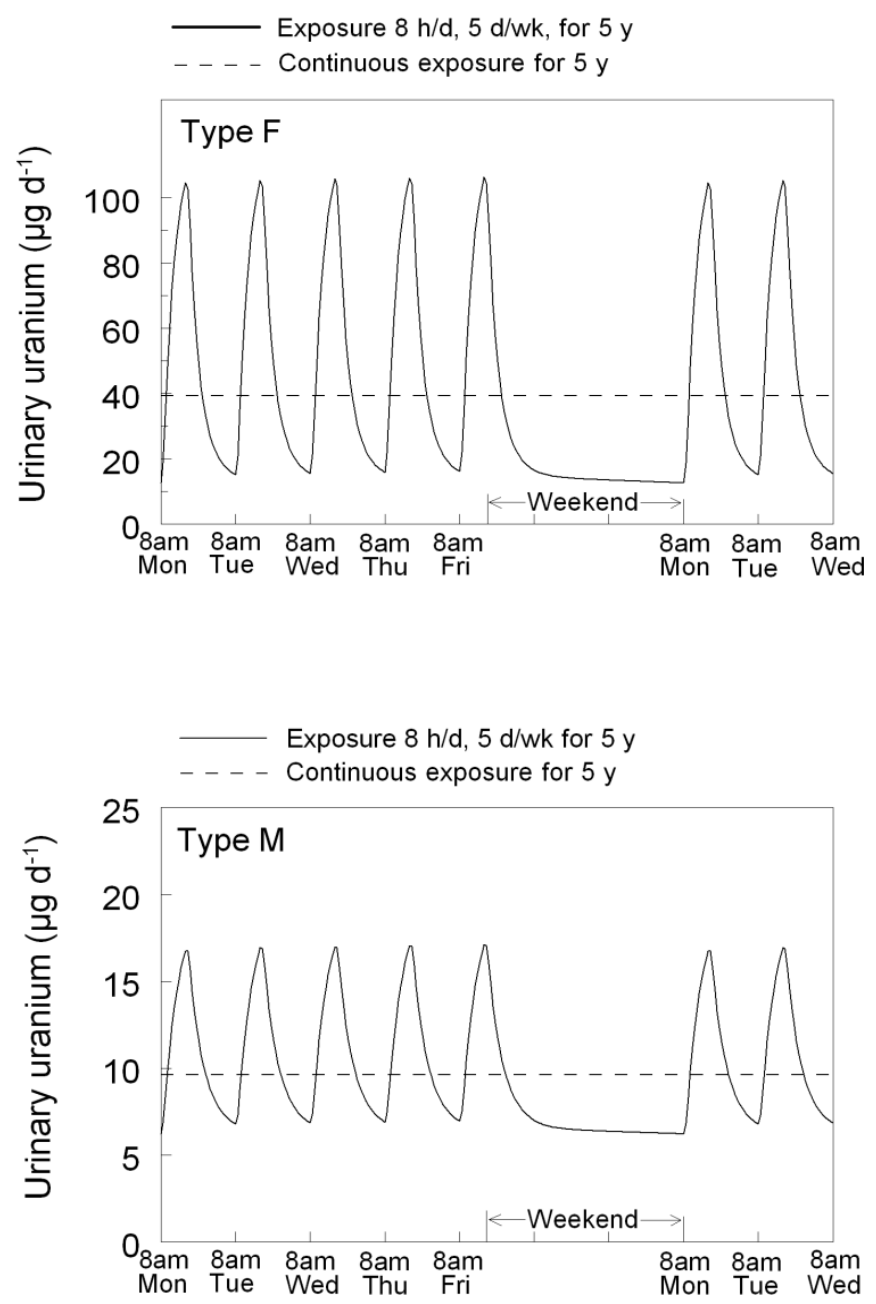

Figure 4.5 For inhalation of a relatively soluble (Type F, top panel) or moderately soluble (Type M, bottom panel) form of uranium $(5 \mu \mathrm{m}$ AMAD, intake $=1 \mathrm{mg} / \mathrm{wk})$, projected urinary excretion rate for different patterns of exposure: continuous intake at a constant rate (dashed curve) or inhalation at a constant rate during regular work hours (solid curve). It is assumed that exposure began 5 y earlier.

To summarize, a major portion of uranium entering blood at time zero is excreted in urine within the next $24 \mathrm{~h}$. As a result, a urine sample collected during or soon after work hours may not provide a useful measure of exposure over the period since the previous urine measurement. In the design of a monitoring program for uranium, the potentially rapid variation in urinary uranium should be taken into account, and a method of urine sampling should be developed with the goal of determining, or at least not underestimating, the average rate of urinary excretion of uranium in each chronically exposed worker. The most efficient or feasible method of meeting this goal may vary from one site to another. A method that may be workable in most cases 
involves collection of a spot sample 48-72 hours after the last potentially elevated exposure to uranium (e.g., upon return to work after a weekend) after potentially large variations in the rate of urinary excretion of uranium have subsided. Due to variation in the rate of urinary excretion of uranium over any 24-h period, the uranium content of a spot sample should be converted to an estimate of 24-h excretion rate of uranium as described in Section A.2 of Appendix A. Also, it should be taken into account that 24-h urinary excretion of urine determined a few days after exposure may underestimate the average concentration in urine. Ideally, the extent of underestimate, if any, would be checked from time to time (perhaps quarterly) by making extensive measurements during a one-week period and comparing the derived average rate of excretion of uranium based on the collective samples with an estimate based on a spot sample collected the next Monday morning. If this type of occasional check on results from spot samples is not feasible at a given site, adjustments to measured concentrations of uranium in urine after removal from exposure for 48-72 $\mathrm{h}$ could be based on model predictions such as those shown in Figures 4.2-4.5. Model predictions described in this section indicate that if the concentration of uranium in air in the work place were constant over an extended period, then the concentration of uranium in a Monday morning urine sample would be roughly a factor of 3.5 below the average based on 168 hours of continuous exposure for inhalation of uranium as Type $\mathrm{F}$ material and roughly a factor of 2 below the average for inhalation of uranium as Type $\mathrm{M}$ or Type $\mathrm{S}$ material.

The above considerations apply to chronic rather than acute exposures. After an acute exposure the urinary uranium concentrations are expected to change in a somewhat smoother (although not perfectly smooth) pattern than suggested in Figures 4.1-4.5 for chronic occupational intakes. This is illustrated in Figure 4.6, which shows the pattern of decline of urinary uranium in a worker acutely exposed to uranium as an oxide (actual case study).

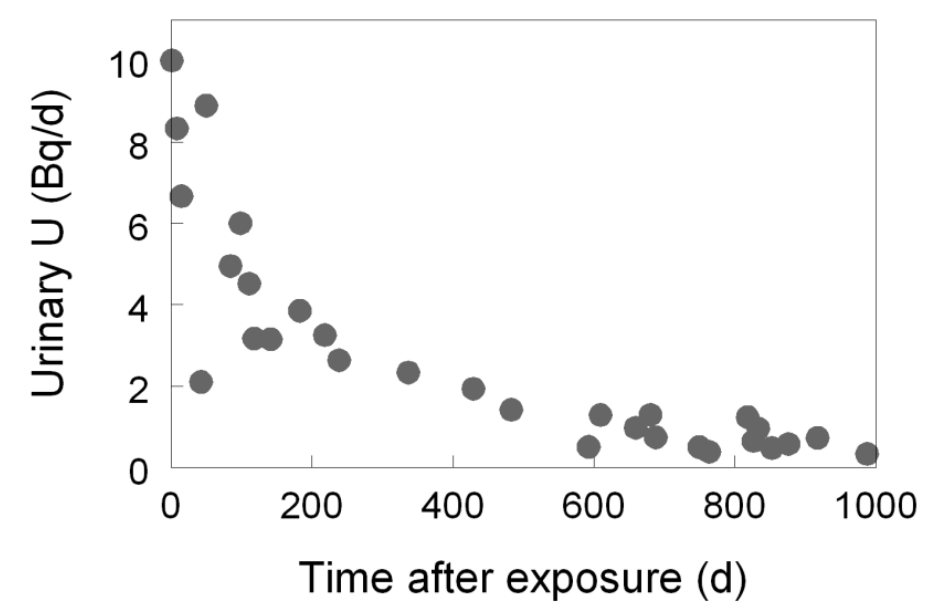

Figure 4.6 Sequential measurements of urinary uranium in a worker acutely exposed to uranium as an oxide. 


\section{DERIVATION OF INVESTIGATION AND IMMEDIATE ACTION LEVELS}

\subsection{Objective}

The investigation and immediate action levels given in Table 1.1 are expressed in terms of the uranium concentration in the kidneys and the annual effective dose, which are not measurable quantities. The present section gives investigation levels and immediate action levels in terms of measurable quantities. Derivations of action values are explained in sufficient detail to allow calculation of site-specific values when warranted.

\subsection{Models and Assumptions Used in the Derivations}

It is not known whether there are significant differences with gender in the biokinetics of uranium, dose per unit exposure to airborne uranium, or concentration of uranium in the kidneys per unit exposure. Some components of the models used to calculate dose or tissue concentration per unit intake of uranium apparently depend on gender, but these factors tend to offset one another in calculations of dose or tissue concentration per unit exposure to airborne uranium. For example, the average adult female might receive a higher effective dose per unit intake of uranium than the average adult male due to gender differences in organ masses, but in terms of effective dose per unit exposure to airborne uranium this difference would be offset by gender differences in air intake rates. Similarly, it might be that the concentration of uranium in the kidneys builds to a higher level on average in adult females than adult males following inhalation of a unit mass of uranium due to gender differences in kidney mass, but the kidney concentration per unit exposure may not be strongly gender dependent due to offsetting gender differences in the air intake rate.

The action levels derived in this report are based on characteristics of a reference adult male as defined in ICRP Publication 89 (2002). Derivations of action levels involving the rate of intake of airborne uranium are based on a breathing rate of $1.2 \mathrm{~m}^{3} \mathrm{~h}^{-1}$. Derivations involving chronic exposure to airborne uranium in the workplace are based on exposure to a fixed concentration of uranium in air for $2000 \mathrm{~h} \mathrm{y}^{-1}$, giving an annual air intake $2400 \mathrm{~m}^{3}$. The volume of urine excreted daily is assumed to be $1.6 \mathrm{~L}$ and the mass of feces excreted daily is assumed to be $150 \mathrm{~g}$, based on reference values for an adult male given in ICRP Publication 89 (2002b). The assumed particle size of airborne uranium is $5 \mu \mathrm{m}$ AMAD, the default value for occupational intake recommended in ICRP Publication 68 (1994b). The models summarized in Section 3 or, where applicable, the tables of model predictions in Section 3 are used to convert the primary chemical and radiological guidance levels to measurable quantities.

The isotopic mixtures of uranium considered in this section are depleted, natural, and enriched uranium with different levels of ${ }^{235} \mathrm{U}$ enrichment. Natural uranium is assumed to contain $0.0057 \%{ }^{234} \mathrm{U}, 0.72 \%{ }^{235} \mathrm{U}$, and $99.2743 \%{ }^{238} \mathrm{U}$ by mass, corresponding to $50.45 \%{ }^{234} \mathrm{U}, 2.20 \%$ ${ }^{235} \mathrm{U}$, and $47.35 \%{ }^{238} \mathrm{U}$ by activity based on specific activities of ${ }^{234} \mathrm{U},{ }^{235} \mathrm{U}$, and ${ }^{238} \mathrm{U}$ given in Table 3.17. Depleted uranium is assumed to contain $0.0005 \%{ }^{234} \mathrm{U}, 0.25 \%{ }^{235} \mathrm{U}$, and $99.7495 \%$ ${ }^{238} \mathrm{U}$ by mass, corresponding to $8.39 \%{ }^{234} \mathrm{U}, 1.45 \%{ }^{235} \mathrm{U}$, and $90.16 \%{ }^{238} \mathrm{U}$ by activity based on 
specific activities of these isotopes given in Table 3.17. The ${ }^{234} \mathrm{U}$ content of enriched uranium is assumed to be related to the ${ }^{235} \mathrm{U}$ content by the equation:

$$
\%^{234} \mathrm{U}=0.0015+0.0058 \mathrm{E}+0.000054 \mathrm{E}^{2}
$$

where, $\mathrm{E}=\%{ }^{235} \mathrm{U}$ by mass. Equation 5.1 is a curve fit to measurements of ${ }^{234} \mathrm{U}$ in uranium enriched by the gaseous diffusion technique. The equation is reasonably consistent with limited data on the ${ }^{234} \mathrm{U}$ content of uranium enriched by the gas centrifuge method (Bush et al. 2001).

Equation 5.1 can be used together with the specific activities of ${ }^{234} \mathrm{U},{ }^{235} \mathrm{U}$, and ${ }^{238} \mathrm{U}$ given in Table 3.17 to derive the following expression for the specific activity, SpA, of depleted, natural, or enriched uranium:

$$
S p A=\left(3.7 \times 10^{4}\right)\left(0.43+0.38 E+0.0034 E^{2}\right) B q / g
$$

The factor $0.43+0.38 \mathrm{E}+0.0034 \mathrm{E}^{2}$ in Equation 5.2 represents the specific activity in units of $\mu \mathrm{Ci} / \mathrm{g}$ (units traditionally used in the United States), and the factor $3.7 \times 10^{4}$ is used to convert from $\mu \mathrm{Ci} / \mathrm{g}$ to $\mathrm{Bq} / \mathrm{g}$. The factor $0.43+0.38 \mathrm{E}+0.0034 \mathrm{E}^{2}$ is nearly identical to the expression for the specific activity of enriched uranium given in Appendix B to 10CRF20: $0.4+0.38 \mathrm{E}+$ $0.0034 \mathrm{E}^{2} \mu \mathrm{Ci} / \mathrm{g}$.

Derivations of action levels for acute exposure, defined as an exposure occurring within an 8-h workday, are based on the assumption of instantaneous intake of uranium. Derivations for exposure periods between one day and one month (typically about 22 workdays) are based on an intermittent exposure pattern approximating potential exposure times during a workweek. For example, action levels for the average concentration of uranium in air for a 40-h workweek are based on the assumption of continuous intake of uranium at a constant rate from 8 am to 4 pm each workday for five consecutive days, with no lunch break or other breaks. Calculations for chronic exposures over periods greater than one month are based on the assumption of continuous intake 24 hours a day and 7 days each week at a rate that produces the intended total intake per workweek. For example, if it is assumed that total intake during each 8-h workday is $1 \mu \mathrm{g}$, then the weekly intake would be 5 workdays/wk $\times 1 \mu \mathrm{g} /$ workday $=5 \mu \mathrm{g} / \mathrm{wk}$, and the intake rate based on the computationally convenient assumption of continuous exposure would be:

$$
(5 \mu \mathrm{g} / \mathrm{wk}) /(7 \mathrm{~d} / \mathrm{wk})=0.714 \mu \mathrm{g} / \mathrm{d} \text {. }
$$

\subsection{Action Levels Based on Air Monitoring}

This section provides information on action levels for the case of exposure to an unknown form of airborne uranium ("worst case") and for cases where some information is known on the absorption type or the isotopic composition (e.g., percent ${ }^{235} \mathrm{U}$ enrichment) or both. 


\subsubsection{Action Levels for the Concentration of Airborne Uranium if the Form of Uranium is Not Known}

In many cases of exposure to airborne uranium the form of inhaled uranium is not known with much certainty. Secondary reference guidance levels for such cases are set to: (1) prevent nephrotoxicity assuming a worst-case situation with regard to the solubility of the airborne material [i.e., 100\% of airborne uranium is assumed to be relatively soluble (Type F)]; and (2) limit radiogenic cancer risk assuming a worst-case situation for radiological toxicity with regard to the solubility of airborne uranium [i.e., $100 \%$ of airborne uranium is assumed to be ${ }^{234} \mathrm{U}$ in relatively insoluble form (Type S)]. Effective dose coefficients for ${ }^{234} \mathrm{U}$ are applied as a cautious measure in that the isotopic ratio of uranium often is not known with much certainty, and coefficients for ${ }^{234} \mathrm{U}$ are slightly higher than coefficients for ${ }^{235} \mathrm{U}$ or ${ }^{238} \mathrm{U}$ (Table 3.16). If information is sufficient to narrow the range of plausible forms of uranium, the secondary reference guidance levels provided below could be modified by applying the same methods to the narrower range of plausible situations.

The peak concentration of uranium in the kidneys resulting from intake of a given mass of uranium depends on the length of the exposure period. Thus, action levels designed to avoid chemical toxicity are provided here for relatively short, intermediate, and relatively long exposure periods.

The estimated committed effective dose from annual intake of a given activity of uranium is independent of the pattern of intake during the year, but it is important to bound intake of activity in any given part of the year to avoid having to impose stringent action levels during other parts of the year. Hence, action levels designed to limit radiation effects are also provided here for short, intermediate, and long exposure periods.

The biokinetic models described in Section 3 predict that inhalation of air with a mass concentration of $1 \mu \mathrm{g} \mathrm{U} / \mathrm{m}^{3}$ over a single 40 -h work week results in a predicted peak kidney concentration of $0.0044 \mu \mathrm{g} \mathrm{U} / \mathrm{g}$ kidney, based on Type F material of particle size $5 \mu \mathrm{m}$ AMAD. Investigation and immediate action levels for avoidance of chemical toxicity are based on peak kidney concentrations of 0.3 and $1.0 \mu \mathrm{g} \mathrm{U} / \mathrm{g}$ kidney, respectively (Table 1.1). The investigation level for the average concentration of uranium in air over a 40 -h workweek is calculated as follows:

$$
1 \mu \mathrm{g} \mathrm{U} / \mathrm{m}^{3} \times(0.3 \mu \mathrm{g} \mathrm{U} / \mathrm{g}) /(0.0044 \mu \mathrm{g} \mathrm{U} / \mathrm{g})=68 \mu \mathrm{g} \mathrm{U} / \mathrm{m}^{3} .
$$

The immediate action level is calculated as follows:

$$
1 \mu \mathrm{g} \mathrm{U} / \mathrm{m}^{3} \times(1.0 \mu \mathrm{g} \mathrm{U} / \mathrm{g}) / 0.0044 \mu \mathrm{g} \mathrm{U} / \mathrm{g}=227 \mu \mathrm{g} \mathrm{U} / \mathrm{m}^{3} .
$$

This derived immediate action level is conservatively rounded down to $200 \mu \mathrm{g} \mathrm{U} / \mathrm{m}^{3}$. For consistency between different action levels, the immediate action level of $68 \mu \mathrm{g} \mathrm{U} / \mathrm{m}^{3}$ derived above is rounded down to $60 \mu \mathrm{g} \mathrm{U} / \mathrm{m}^{3}$ (i.e., 0.3 times the rounded immediate action level). 
Inhalation of air with a concentration of $1 \mu \mathrm{g} \mathrm{U} / \mathrm{m}^{3}$ over two consecutive workweeks results in a predicted peak kidney concentration of about $0.0068 \mu \mathrm{g} \mathrm{U} / \mathrm{g}$ kidney. The investigation level based on this concentration is calculated as follows:

$$
1 \mu \mathrm{g} \mathrm{U} / \mathrm{m}^{3} \times(0.3 \mu \mathrm{g} \mathrm{U} / \mathrm{g}) / 0.0068 \mu \mathrm{g} \mathrm{U} / \mathrm{g}=44 \mu \mathrm{g} \mathrm{U} / \mathrm{m}^{3} \text {. }
$$

The immediate action level is calculated as follows:

$$
1 \mu \mathrm{g} \mathrm{U} / \mathrm{m}^{3} \times(1.0 \mu \mathrm{g} \mathrm{U} / \mathrm{g}) / 0.0068 \mu \mathrm{g} \mathrm{U} / \mathrm{g}=147 \mu \mathrm{g} \mathrm{U} / \mathrm{m}^{3}
$$

These investigation and immediate action levels are rounded to 45 and $150 \mu \mathrm{g} \mathrm{U} / \mathrm{m}^{3}$, respectively.

Inhalation of air with a concentration of $1 \mu \mathrm{g} \mathrm{U} / \mathrm{m}^{3}$ over one month (22 workdays) results in a predicted peak kidney concentration of about $0.009 \mu \mathrm{g} \mathrm{U} / \mathrm{g}$ kidney. The investigation level based on this concentration is calculated as follows:

$$
1 \mu \mathrm{g} \mathrm{U} / \mathrm{m}^{3} \times(0.3 \mu \mathrm{g} \mathrm{U} / \mathrm{g}) / 0.009 \mu \mathrm{g} \mathrm{U} / \mathrm{g}=33 \mu \mathrm{g} \mathrm{U} / \mathrm{m}^{3} \text {. }
$$

The immediate action level is calculated as follows:

$$
1 \mu \mathrm{g} \mathrm{U} / \mathrm{m}^{3} \times(1.0 \mu \mathrm{g} \mathrm{U} / \mathrm{g}) / 0.009 \mu \mathrm{g} \mathrm{U} / \mathrm{g}=111 \mu \mathrm{g} \mathrm{U} / \mathrm{m}^{3} \text {. }
$$

These investigation and immediate action levels are rounded to 30 and $100 \mu \mathrm{g} \mathrm{U} / \mathrm{m}^{3}$, respectively.

For avoidance of chemical toxicity, action levels for long-term average concentrations of uranium in air, defined as averages over 3 mo or longer, are based on predicted equilibrium concentrations of uranium in the kidneys occurring for long-term continuous exposure to airborne uranium at a constant rate. As indicated in Section 3, daily inhalation of $1 \mu \mathrm{g}$ of Type F uranium of particle size $5 \mu \mathrm{m}$ AMAD for an extended period is predicted to result in an equilibrium concentration of $0.003 \mu \mathrm{g} \mathrm{U} / \mathrm{g}$ kidney. The intake rate that would result in an equilibrium concentration of $0.3 \mu \mathrm{g} \mathrm{U} / \mathrm{g}$ kidney, the investigation level, is calculated as follows:

$$
(0.3 / 0.003) \mu \mathrm{g} \mathrm{U} / \mathrm{d}=100 \mu \mathrm{g} \mathrm{U} / \mathrm{d}=36,500 \mu \mathrm{g} \mathrm{U} / \mathrm{y} .
$$

The mass concentration of Type F uranium in air in the workplace corresponding to this intake rate is calculated as follows:

$$
36,500 \mu \mathrm{g} / \mathrm{y} /\left[(2000 \mathrm{~h} / \mathrm{y}) \cdot\left(1.2 \mathrm{~m}^{3} / \mathrm{h}\right)\right]=15 \mu \mathrm{g} / \mathrm{m}^{3}
$$

The fixed mass concentration of Type $\mathrm{F}$ material in air that would result in an equilibrium concentration of $1.0 \mu \mathrm{g} \mathrm{U} / \mathrm{g}$ kidney (an immediate action level) is calculated as follows:

$$
(1.0 / 0.3) \times 15 \mu \mathrm{g} / \mathrm{m}^{3}=50 \mu \mathrm{g} / \mathrm{m}^{3} .
$$


Action levels for limitation of radiation effects are based on the assumption that airborne uranium is in relatively insoluble form (Type $S$ ). The committed effective dose coefficient for inhalation of ${ }^{234} \mathrm{U}$ of Type $\mathrm{S}\left(5 \mu \mathrm{m}\right.$ AMAD) is $6.8 \times 10^{-6} \mathrm{~Sv} / \mathrm{Bq}$. The annual intake of ${ }^{234} \mathrm{U}$ of Type $\mathrm{S}$ corresponding to an effective dose of $0.02 \mathrm{~Sv}$ (investigation level) is calculated as follows:

$$
0.02 \mathrm{~Sv} / 6.8 \times 10^{-6} \mathrm{~Sv} / \mathrm{Bq}=2940 \mathrm{~Bq}
$$

The fixed activity concentration of ${ }^{234} U$ in air based on this intake over one year of occupational exposure is calculated as follows:

$$
2940 \mathrm{~Bq} / \mathrm{y} /\left[(2000 \mathrm{~h} / \mathrm{y}) \cdot\left(1.2 \mathrm{~m}^{3} / \mathrm{h}\right)\right]=1.2 \mathrm{~Bq} / \mathrm{m}^{3} \text {. }
$$

The fixed activity concentration of ${ }^{234} \mathrm{U}$ in air corresponding to an annual effective dose of $0.05 \mathrm{~Sv}$ (immediate action level) is calculated as follows:

$$
(0.05 \mathrm{~Sv} / 0.02 \mathrm{~Sv}) \times 1.2 \mathrm{~Bq} / \mathrm{m}^{3}=3.0 \mathrm{~Bq} / \mathrm{m}^{3}
$$

The action levels derived above for an unknown form of airborne uranium are summarized in Table 5.1. For consistency with action levels based on mass concentration, the activity concentrations applied to long-term exposure is increased by factors of 2, 3, and 4 for application to exposures over $1 \mathrm{mo}, 2 \mathrm{wk}$, and $1 \mathrm{wk}$, respectively.

For example, if the mass concentration of uranium in air averaged over 3 mo does not exceed $15 \mu \mathrm{g} / \mathrm{m}^{3}$ and the average activity concentration over that time does not exceed $1.2 \mathrm{~Bq} / \mathrm{m}^{3}$, uranium confinement is considered to be adequate and no action is required. If the average mass concentration in air exceeds $15 \mu \mathrm{g} / \mathrm{m}^{3}$ but does not exceed $50 \mu \mathrm{g} / \mathrm{m}^{3}$, or the average activity concentration in air exceeds $1.2 \mathrm{~Bq} / \mathrm{m}^{3}$ but does not exceed $3.0 \mathrm{~Bq} / \mathrm{m}^{3}$, an investigation level has been reached and the investigative procedures listed in Table 1.1 should be performed. If the average mass concentration in air exceeds $50 \mu \mathrm{g} / \mathrm{m}^{3}$ or the average activity concentration in air exceeds $3.0 \mathrm{~Bq} / \mathrm{m}^{3}$, an immediate action level has been reached and the immediate actions listed in Table 1.1 should be performed.

For depleted uranium, natural uranium, or slightly enriched uranium, the mass concentrations given in Table 5.1 are more restrictive than the corresponding activity concentrations. With regard to the investigation level, the activity concentration $1.2 \mathrm{~Bq} / \mathrm{m}^{3}$ is more restrictive than the mass concentration $15 \mu \mathrm{g} / \mathrm{m}^{3}$ for ${ }^{235} \mathrm{U}$ enrichment levels greater than $4.5 \%$. With regard to the immediate action level, the activity concentration $3 \mathrm{~Bq} / \mathrm{m}^{3}$ is more restrictive than the mass concentration $50 \mu \mathrm{g} / \mathrm{m}^{3}$ for ${ }^{235} \mathrm{U}$ enrichment levels greater than $3 \%$. 
Table 5.1 Investigation and immediate action levels of uranium in air for application to cases in which the form of uranium is not known

\begin{tabular}{|c|c|c|}
\hline Level & $\begin{array}{c}\text { Mass } \\
\text { concentration } \\
\left(\mu \mathrm{g} / \mathbf{m}^{3}\right) \\
\end{array}$ & $\begin{array}{c}\text { Activity } \\
\text { concentration } \\
\left(\mathbf{B q} / \mathbf{m}^{3}\right) \\
\end{array}$ \\
\hline \multicolumn{3}{|l|}{ Investigation level $^{a}$} \\
\hline Average over a $40-\mathrm{h}$ workweek & 60 & $4.8^{b}$ \\
\hline Average over 2 consecutive 40 -h workweeks & 45 & $3.6^{b}$ \\
\hline Average over a month (22 workdays) & 30 & $2.4^{b}$ \\
\hline Average over 3 mo & 15 & 1.2 \\
\hline \multicolumn{3}{|l|}{ Immediate action level $^{a}$} \\
\hline Average over a 40 -h workweek & 200 & $12^{b}$ \\
\hline Average over 2 consecutive 40 -h workweeks & 150 & $9.0^{b}$ \\
\hline Average over a month (22 workdays) & 100 & $6.0^{b}$ \\
\hline Average over 3 mo & 50 & 3.0 \\
\hline
\end{tabular}

The action levels listed in Table 5.1 have implications regarding action levels for shorter exposure periods. For example, an 8 -h average air concentration exceeding $1 \mathrm{mg} \mathrm{U} / \mathrm{m}^{3}$ indicates that immediate action is needed because the average over a 40 -h workweek would exceed $200 \mu \mathrm{g} \mathrm{U} / \mathrm{m}^{3}$ regardless of the air concentration during the remainder of the week. Similarly, an average air concentration of $23 \mu \mathrm{g} \mathrm{U} / \mathrm{m}^{3}$ for two consecutive months indicates that immediate action is needed because the average over 3 mo would exceed $15 \mu \mathrm{g} \mathrm{U} / \mathrm{m}^{3}$ regardless of the air concentration during the third month.

\subsubsection{Action Levels for the Concentration of Uranium in Air for Reasonably Well Characterized Forms of Uranium}

If airborne uranium is reasonably well characterized with regard both to solubility and isotopic mixture, higher action levels than those given in Table 5.1 may apply. In the following hypothetical example, action levels for the air concentration of uranium averaged over a 1-y period are recalculated on the basis of known characteristics of the airborne material.

Example 5.1. Suppose airborne uranium is known to be depleted uranium with solubility properties consistent with Type M material, and the particle size is determined to be about $5 \mu \mathrm{m}$ AMAD. As indicated in Section 3, the equilibrium concentration of uranium in the kidneys based on continuous inhalation at the rate $1 \mu \mathrm{g} \mathrm{U} / \mathrm{d}$ is $0.00075 \mu \mathrm{g} \mathrm{U} / \mathrm{g}$ kidney for Type $\mathrm{M}$ material ( $5 \mu \mathrm{m}$ AMAD). The annual intake eventually leading to the limiting concentration of $0.3 \mu \mathrm{g} \mathrm{U} / \mathrm{g}$ kidney is calculated as:

$$
\text { (365 d x } 1 \mu \mathrm{g} \mathrm{U} / \mathrm{d} \text { x } 0.3 \mu \mathrm{g} \mathrm{U} / \mathrm{g} \text { kidney) / } 0.00075 \mu \mathrm{g} \mathrm{U} / \mathrm{g} \text { kidney = 146,000 } \mu \mathrm{g} \mathrm{U} \text {. }
$$


The concentration of uranium in air corresponding to this intake, and hence to an equilibrium concentration of $0.3 \mu \mathrm{g} \mathrm{U} / \mathrm{g}$ kidney, is derived by dividing $146,000 \mu \mathrm{g}$ by the reference value for occupational intake of air in a year:

$$
146,000 \mu \mathrm{g} / 2400 \mathrm{~m}^{3}=61 \mu \mathrm{g} / \mathrm{m}^{3} \text {. }
$$

Thus, the chemically based investigation level for this known form of airborne uranium is about four times greater than the chemically based investigation level for airborne uranium of unknown form (Table 5.1).

The radiologically based investigation level in terms of mass concentration of airborne depleted uranium of Type $\mathrm{M}$ and particle size $5 \mu \mathrm{m}$ AMAD is calculated as:

$$
\left[(0.02 \mathrm{~Sv} / \mathrm{E}) / 2400 \mathrm{~m}^{3}\right] / \mathrm{SpA}(\mathrm{DU})
$$

where $\mathrm{E}$ is the effective dose coefficient for depleted uranium with the reference isotopic composition given in Section 5.2 and $\mathrm{SpA}(\mathrm{DU})$ is the specific activity of that isotopic mixture.

The value $\mathrm{E}$ is derived as a linear combination of the effective dose coefficients given in Table 3.16 for ${ }^{234} \mathrm{U}\left(2.1 \times 10^{-6} \mathrm{~Sv} / \mathrm{Bq}\right),{ }^{235} \mathrm{U}\left(1.8 \times 10^{-6} \mathrm{~Sv} / \mathrm{Bq}\right)$, and ${ }^{238} \mathrm{U}\left(1.6 \times 10^{-6} \mathrm{~Sv} / \mathrm{Bq}\right)$ of Type $\mathrm{M}$ and particle size $5 \mu \mathrm{m}$ AMAD:

$$
\begin{aligned}
\mathrm{E}= & 0.0839 \times\left(2.1 \times 10^{-6} \mathrm{~Sv} / \mathrm{Bq}\right)+0.0145 \times\left(1.8 \times 10^{-6} \mathrm{~Sv} / \mathrm{Bq}\right) \\
& +0.9016 \times\left(1.6 \times 10^{-6} \mathrm{~Sv} / \mathrm{Bq}\right)=1.645 \times 10^{-6} \mathrm{~Sv} / \mathrm{Bq},
\end{aligned}
$$

where, $0.0839,0.0145$, and 0.9016 are reference fractions of total activity in depleted uranium represented by ${ }^{234} \mathrm{U},{ }^{235} \mathrm{U}$, and ${ }^{238} \mathrm{U}$, respectively (Section 5.2). Thus, the radiologically based investigation level for the air concentration of this form of uranium is

$$
\left[0.02 \mathrm{~Sv} / 1.645 \times 10^{-6} \mathrm{~Sv} / \mathrm{Bq}\right] / 2400 \mathrm{~m}^{3}=5.065 \mathrm{~Bq} / \mathrm{m}^{3} \text {. }
$$

This investigation level is about four times greater than the radiologically based investigation level for airborne uranium of unknown form (Table 5.1).

Based on the reference composition of depleted uranium given in Section 5.2, the specific activity $\operatorname{SpA}(\mathrm{DU})$ of depleted uranium is $1.383 \times 10^{4} \mathrm{~Bq} / \mathrm{g}$. Therefore, the radiologically based investigation level of $5.065 \mathrm{~Bq} / \mathrm{m}^{3}$ derived above is equivalent to

$$
5.065 \mathrm{~Bq} / \mathrm{m}^{3} / 1.383 \times 10^{4} \mathrm{~Bq} / \mathrm{g}=0.000366 \mathrm{~g} / \mathrm{m}^{3}=366 \mu \mathrm{g} / \mathrm{m}^{3} .
$$

Thus, the chemically based investigation level of $61 \mu \mathrm{g} / \mathrm{m}^{3}$ derived earlier is more restrictive than the radiologically based value for airborne depleted uranium of Type $\mathrm{M}$ and particle size $5 \mu \mathrm{m}$ AMAD. 
The methods used in the above example to derive a radiologically based action level for depleted uranium of known solubility and particle size can be generalized to any form of airborne uranium of known solubility, isotopic composition, and particle size. The following equation can be used to derive a radiologically based investigation level $R$ in units of $\mu \mathrm{g} \mathrm{U} / \mathrm{m}^{3}$ and hence directly comparable with chemically based levels:

$$
\begin{gathered}
R=\left(0.02 S v \times 10^{6} \mu g / g\right) \div \\
{\left[\left(2400 m^{3} \times F 4 \times E 4 \times S 4\right)+(F 5 \times E 5 \times S 5)+(F 8 \times E 8 \times S 8)\right]}
\end{gathered}
$$

where,

$0.02 \mathrm{~Sv}$ is the primary reference guidance level for radiologically based investigation levels; $\mathrm{F} 4, \mathrm{~F} 5$, and F8 are mass fractions of ${ }^{234} \mathrm{U},{ }^{235} \mathrm{U}$, and ${ }^{238} \mathrm{U}$, respectively, in the material;

$\mathrm{E} 4, \mathrm{E} 5$, and E8 are effective dose coefficients (Sv/Bq) for ${ }^{234} \mathrm{U},{ }^{235} \mathrm{U}$, and ${ }^{238} \mathrm{U}$, respectively, each derived on the basis of the solubility and particle size distribution of the material; $\mathrm{S} 4=$ specific activity of ${ }^{234} \mathrm{U}=2.32 \times 10^{8} \mathrm{~Bq} / \mathrm{g}$;

$\mathrm{S} 5=$ specific activity of ${ }^{235} \mathrm{U}=8.01 \times 10^{4} \mathrm{~Bq} / \mathrm{g}$;

$\mathrm{S} 8=$ specific activity of ${ }^{238} \mathrm{U}=1.25 \times 10^{4} \mathrm{~Bq} / \mathrm{g}$; and

$2400 \mathrm{~m}^{3}$ is a reference value for annual intake of air during work hours.

Equation 5.3 was used to calculate radiologically based investigation levels for airborne uranium (averages over a 1-y period) in units of $\mu \mathrm{g} \mathrm{U} / \mathrm{m}^{3}$, for depleted uranium, natural uranium, or ${ }^{235} \mathrm{U}$ enriched uranium of Type F, Type M, or Type $\mathrm{S}$. The default particle size $5 \mu \mathrm{m}$ AMAD was applied. Effective dose coefficients E4, E5, and E8 for these absorption types were taken from Table 3.16. Results of the analysis are summarized and compared with chemically based investigation levels in Figure 5.1 and Table 5.2. The chemically based investigation levels are derived from the equilibrium concentrations of uranium in the kidneys indicated in Section 3 for continuous inhalation of uranium at the constant rate of $1 \mu \mathrm{g} / \mathrm{d}$ :

\section{$0.003 \mu \mathrm{g} \mathrm{U} / \mathrm{g}$ kidney for Type F; $0.00075 \mu \mathrm{g} \mathrm{U} / \mathrm{g}$ kidney for Type M; $0.000078 \mu \mathrm{g} \mathrm{U} / \mathrm{g}$ kidney for Type S.}

The method of calculation of the chemically based investigation levels was described earlier.

The labels $\operatorname{Rad} \mathrm{X}$ and Chem X, where X represents absorption type F, M, or S, in Figure 5.1 refer to radiologically (Rad) and chemically (Chem) based limits, respectively, for inhalation of uranium of Type $\mathrm{X}$. The investigation level for Type $\mathrm{X}$ and a given isotopic composition is determined by the lower of the curves Chem $X$ and $\operatorname{Rad} X$ at their points of intersection with a vertical line drawn through the ${ }^{235} \mathrm{U}$ content on the horizontal axis. If the percentage of ${ }^{235} \mathrm{U}$ by weight is known, but the solubility of the material is unknown, the lower of the curves Chem F and Rad S directly above the percentage of ${ }^{235} \mathrm{U}$ by weight should be used. If the percentage of ${ }^{235} \mathrm{U}$ by weight is known only within a range, the upper limit of the range should be used. 
The calculations indicate the following with regard to investigation levels for airborne depleted, natural, or ${ }^{235} \mathrm{U}$-enriched uranium of particle size 5 $\mu$ m AMAD:

- Investigation levels derived from the chemical primary reference guidance level depend on the solubility but not the isotopic composition of the airborne material and are 15 $\mu \mathrm{g} / \mathrm{m}^{3}, 61 \mu \mathrm{g} / \mathrm{m}^{3}$, and $585 \mu \mathrm{g} / \mathrm{m}^{3}$ for Types F, M, and S, respectively.

- Investigation levels derived from the radiological primary reference guidance level vary with the isotopic composition as well as the solubility of the airborne material and become increasingly restrictive with increasing ${ }^{235} \mathrm{U}$ content, due primarily to increasing levels of accompanying ${ }^{234} \mathrm{U}$.

- For Type F material, the chemical reference guidance is limiting for ${ }^{235} \mathrm{U}$ content up to about $44 \%{ }^{235} \mathrm{U}$ by mass, and radiological reference guidance is limiting for higher ${ }^{235} \mathrm{U}$ content.

- For Type M material, the chemical reference guidance is limiting for ${ }^{235} \mathrm{U}$ content up to about $3.7 \%{ }^{235} \mathrm{U}$ by mass, and the radiological reference guidance is limiting for higher ${ }^{235} \mathrm{U}$ content.

- For Type $\mathrm{S}$ material, the radiological reference guidance is limiting regardless of the isotopic composition of the material.

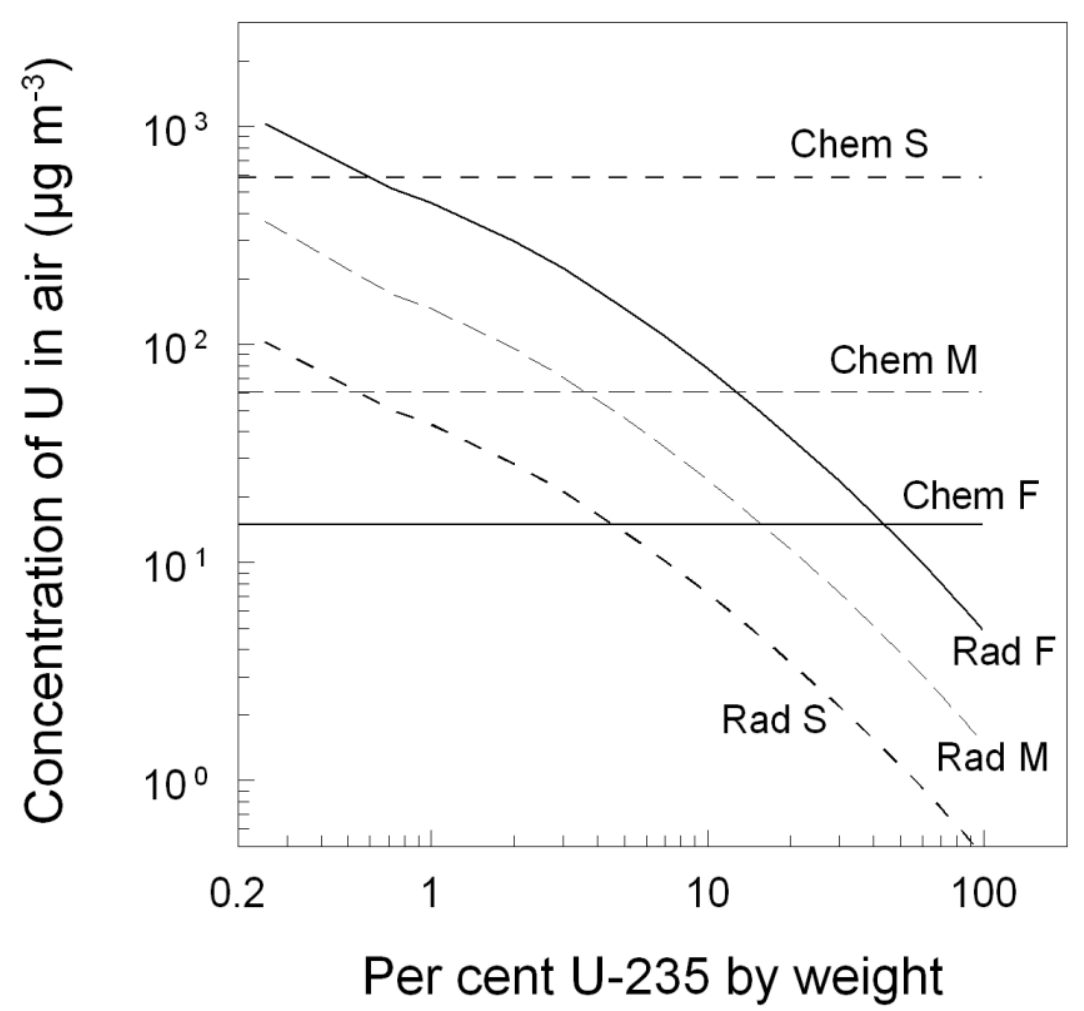

Figure 5.1 Graphs used to determine investigation levels for the concentration of uranium in air. The cases considered are depleted, natural, or ${ }^{235} \mathrm{U}$-enriched uranium of Type $\mathrm{F}, \mathrm{M}$, or $S(5 \mu \mathrm{m}$ AMAD). The investigation level for Type $X(X=F, M$, or $S)$ and a given isotopic composition is determined by the lower of the curves $\operatorname{Chem} X$ and $\operatorname{Rad} X$ at their points of intersection with a vertical line through the ${ }^{235} U$ content (horizontal axis). 
Table 5.2 Investigation levels for the concentration of depleted, natural, or ${ }^{235} \mathrm{U}$ enriched uranium in air for different levels of solubility of uranium, based on the default particle size $5 \mu \mathrm{m}$ AMAD. The investigation level for Type $X(X=F, M$, or $\mathrm{S}$ ) and a given isotopic composition is the lower of the derived values based on chemical and radiological reference guidance.

\begin{tabular}{|c|c|c|c|}
\hline \multirow{2}{*}{$\begin{array}{l}\text { Percentage of }{ }^{235} \mathrm{U} \text { in } \\
\text { mixture by mass }\end{array}$} & \multicolumn{3}{|c|}{ Concentration of uranium in air $\left(\mu \mathrm{g} / \mathrm{m}^{3}\right)$} \\
\hline & Type F & Type M & Type $S$ \\
\hline \multicolumn{4}{|c|}{ Investigation levels based on radiological reference guidance } \\
\hline $0.25^{a}$ & 1030 & 366 & 104 \\
\hline $0.72^{b}$ & 521 & 171 & 50.8 \\
\hline $1^{c}$ & 449 & 146 & 43.5 \\
\hline $2^{c}$ & 299 & 95.4 & 28.8 \\
\hline $3^{c}$ & 224 & 70.5 & 21.4 \\
\hline $4^{c}$ & 178 & 55.7 & 17.0 \\
\hline $5^{c}$ & 147 & 46.0 & 14.0 \\
\hline $7^{c}$ & 109 & 33.8 & 10.3 \\
\hline $10^{c}$ & 77.4 & 23.9 & 7.33 \\
\hline $15^{c}$ & 51.2 & 15.8 & 4.84 \\
\hline $20^{c}$ & 37.6 & 11.5 & 3.55 \\
\hline $30^{c}$ & 23.7 & 7.25 & 2.23 \\
\hline $40^{c}$ & 16.7 & 5.12 & 1.58 \\
\hline $50^{c}$ & 12.6 & 3.86 & 1.19 \\
\hline $60^{c}$ & 9.93 & 3.04 & 0.94 \\
\hline $70^{c}$ & 8.06 & 2.46 & 0.76 \\
\hline $75^{c}$ & 7.33 & 2.24 & 0.69 \\
\hline $80^{c}$ & 6.70 & 2.05 & 0.63 \\
\hline $85^{c}$ & 6.15 & 1.88 & 0.58 \\
\hline $90^{c}$ & 5.67 & 1.73 & 0.53 \\
\hline $93^{c}$ & 5.41 & 1.65 & 0.51 \\
\hline $95^{c}$ & 5.24 & 1.60 & 0.49 \\
\hline $97^{c}$ & 5.09 & 1.55 & 0.48 \\
\hline $99^{c}$ & 4.94 & 1.51 & 0.47 \\
\hline
\end{tabular}

Any mixture of ${ }^{234} \mathrm{U}$,

$$
{ }^{235} \mathrm{U} \text {, and }{ }^{238} \mathrm{U}
$$
585

${ }^{a}$ Represents depleted uranium; ${ }^{234} \mathrm{U}$ content assumed to be $0.0005 \%$ by mass.

${ }^{b}$ Represents unprocessed natural uranium; ${ }^{234} \mathrm{U}$ content assumed to be $0.0057 \%$ by mass.

${ }^{c}$ Derivations of air concentrations of uranium based on relative contents of ${ }^{234} \mathrm{U}$ and ${ }^{235} \mathrm{U}$ typically found in uranium enriched by the gaseous diffusion process. 
Example 5.2. Suppose that workers are exposed to natural uranium in air. The ${ }^{235} \mathrm{U}$ content of natural uranium is about $0.72 \%$ by mass. The investigation level for airborne uranium can be determined either from Figure 5.1 or Table 5.2. Based on Figure 5.1:

- The investigation level for a relatively soluble form (Type F) is about $15 \mu \mathrm{g} / \mathrm{m}^{3}$, because a vertical line passing through 0.72 on the E-axis $\left(\mathrm{E}=\%{ }^{235} \mathrm{U}\right.$ by weight $)$ would intersect the curve labeled Chem $F$ at about $15 \mu \mathrm{g} / \mathrm{m}^{3}$ and the curve Rad $\mathrm{F}$ at a much higher value, about $500 \mu \mathrm{g} / \mathrm{m}^{3}$. In this case the investigation level based on chemical reference guidance is the same as given in Table 5.1 because inhalation of Type F material is the most restrictive situation regarding chemical toxicity when dealing with an unknown form of uranium.

- The investigation level for a moderately soluble form (Type M) is about four times higher $\left(\sim 60 \mu \mathrm{g} / \mathrm{m}^{3}\right)$ than that for Type $\mathrm{F}$, because a vertical line passing through 0.72 on the E-axis would intersect the curve Rad M near $60 \mu \mathrm{g} / \mathrm{m}^{3}$ and would intersect the curve Chem $\mathrm{M}$ at a higher value.

- The investigation level for a relatively insoluble form (Type $S$ ) is about $50 \mu \mathrm{g} / \mathrm{m}^{3}$, because a vertical line passing through 0.72 on the E-axis would intersect the curve Rad S near $50 \mu \mathrm{g} / \mathrm{m}^{3}$ and would intersect the curve Chem S near $600 \mu \mathrm{g} / \mathrm{m}^{3}$.

Table 5.2 is easier to use than Figure 5.1 for natural uranium or other isotopic compositions addressed in the table. Based on Table 5.2:

- The investigation level for a relatively soluble form (Type F) of natural uranium is 15 $\mu \mathrm{g} / \mathrm{m}^{3}$. This is the investigation level for any mixture of ${ }^{234} \mathrm{U},{ }^{235} \mathrm{U}$, and ${ }^{238} \mathrm{U}$ based on chemical reference guidance. It is lower than the value $521 \mu \mathrm{g} / \mathrm{m}^{3}$ based on radiological reference guidance.

- The investigation level for a moderately soluble form (Type M) of natural uranium is $61 \mu \mathrm{g} / \mathrm{m}^{3}$, which is the value based on chemical reference guidance. This value is less than the value $171 \mu \mathrm{g} / \mathrm{m}^{3}$ based on radiological reference guidance.

- The investigation level for a relatively insoluble form (Type $S$ ) of natural uranium is $50.8 \mu \mathrm{g} / \mathrm{m}^{3}$, which is the value based on radiological reference guidance. This value is less than the value $585 \mu \mathrm{g} / \mathrm{m}^{3}$ based on chemical reference guidance.

Analogous graphs and tabulated values for determining immediate action levels for the concentration of depleted, natural, or enriched uranium in air are given in Figure 5.2 and Table 5.3, respectively. The methods of derivation of immediate action levels for different mixtures of ${ }^{234} \mathrm{U},{ }^{235} \mathrm{U}$, and ${ }^{238} \mathrm{U}$ are the same as described above for investigation levels, with the limiting kidney concentration changed from 0.3 to $1.0 \mu \mathrm{g} \mathrm{U} / \mathrm{g}$ kidney and the limiting annual effective dose coefficient changed from 0.02 to $0.05 \mathrm{~Sv}$. 
The calculations indicate the following with regard to immediate action levels for airborne depleted, natural, or ${ }^{235} \mathrm{U}$-enriched uranium of particle size 5 $\mu$ m AMAD:

- Immediate action levels derived from chemical reference guidance depend on the solubility but not the isotopic composition of the airborne material and are $50 \mu \mathrm{g} / \mathrm{m}^{3}, 203$ $\mu \mathrm{g} / \mathrm{m}^{3}$, and $1950 \mu \mathrm{g} / \mathrm{m}^{3}$ for Types F, M, and S, respectively.

- Immediate action levels derived from radiological reference guidance vary with the isotopic composition as well as the solubility of the airborne material and become increasingly restrictive with increasing ${ }^{235} \mathrm{U}$ content, due primarily to increasing levels of accompanying ${ }^{234} \mathrm{U}$.

- For Type F material, chemical reference guidance is limiting for ${ }^{235} \mathrm{U}$ content up to about $35 \%{ }^{235} \mathrm{U}$ by mass, and radiological reference guidance is limiting for higher ${ }^{235} \mathrm{U}$ content.

- For Type $\mathrm{M}$ material, chemical reference guidance is limiting for ${ }^{235} \mathrm{U}$ content up to about $2.5 \%{ }^{235} \mathrm{U}$ by mass, and radiological reference guidance is limiting for higher ${ }^{235} \mathrm{U}$ content.

- For Type S material, radiological reference guidance is limiting regardless of the isotopic composition of the material.

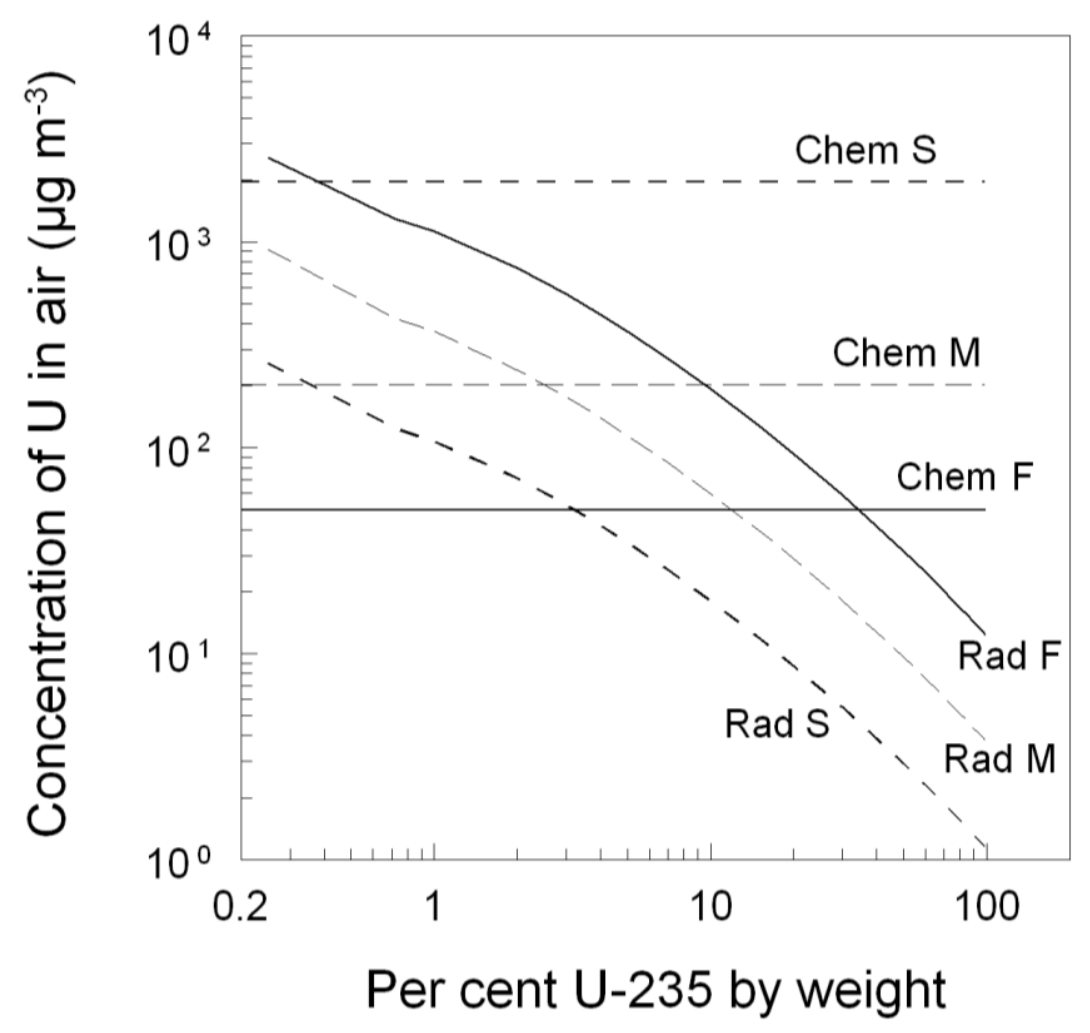

Figure 5.2 Graphs used to determine immediate action levels for the concentration of uranium in air. The cases considered are depleted, natural, or ${ }^{235} \mathrm{U}$-enriched uranium of Type F, M, or S (5 $\mu \mathrm{m}$ AMAD). The immediate action level for Type $X(X=F, M$, or $S)$ and a given isotopic composition is determined by the lower of the curves Chem $X$ and 
Rad $X$ at their points of intersection with a vertical line through the ${ }^{235} \mathrm{U}$ content (horizontal axis).

Table 5.3 Immediate action levels for the concentration of depleted, natural, or ${ }^{235} \mathrm{U}$-enriched uranium in air for different levels of solubility (different absorption types) of uranium, based on the default particle size $5 \mu \mathrm{m}$ AMAD. The immediate action level for Type $X(X=F, M$, or $S)$ and a given isotopic composition is the lower of the derived values based on chemical and radiological reference guidance.

\begin{tabular}{|c|c|c|c|}
\hline \multirow{2}{*}{$\begin{array}{l}\text { Percentage of }{ }^{235} \mathrm{U} \text { in } \\
\text { mixture by mass }\end{array}$} & \multicolumn{3}{|c|}{ Concentration of uranium in air $\left(\mu \mathrm{g} / \mathrm{m}^{3}\right)$} \\
\hline & Type F & Type M & Type $S$ \\
\hline \multicolumn{4}{|c|}{ Investigation levels based on radiological reference guidance } \\
\hline $0.25^{a}$ & 2570 & 916 & 260 \\
\hline $0.72^{b}$ & 1300 & 428 & 127 \\
\hline $1^{c}$ & 1120 & 365 & 109 \\
\hline $2^{c}$ & 748 & 238 & 71.9 \\
\hline $3^{c}$ & 559 & 176 & 53.5 \\
\hline $4^{c}$ & 445 & 139 & 42.4 \\
\hline $5^{c}$ & 368 & 115 & 35.0 \\
\hline $7^{c}$ & 272 & 84.5 & 25.8 \\
\hline $10^{c}$ & 193 & 59.8 & 18.3 \\
\hline $15^{c}$ & 128 & 39.4 & 12.1 \\
\hline $20^{c}$ & 93.9 & 28.8 & 8.87 \\
\hline $30^{c}$ & 59.1 & 18.1 & 5.58 \\
\hline $40^{c}$ & 41.8 & 12.8 & 3.94 \\
\hline $50^{c}$ & 31.5 & 9.65 & 2.97 \\
\hline $60^{c}$ & 24.8 & 7.59 & 2.34 \\
\hline $70^{c}$ & 20.2 & 6.16 & 1.90 \\
\hline $75^{c}$ & 18.3 & 5.60 & 1.73 \\
\hline $80^{c}$ & 16.7 & 5.12 & 1.58 \\
\hline $85^{c}$ & 15.4 & 4.70 & 1.45 \\
\hline $90^{c}$ & 14.2 & 4.33 & 1.34 \\
\hline $93^{c}$ & 13.5 & 4.13 & 1.27 \\
\hline $95^{c}$ & 13.1 & 4.00 & 1.23 \\
\hline $97^{c}$ & 12.7 & 3.88 & 1.20 \\
\hline $99^{c}$ & 12.3 & 3.77 & 1.16 \\
\hline
\end{tabular}

Investigation levels based on chemical reference guidance

\footnotetext{
Any mixture of ${ }^{234} \mathrm{U}, \quad 50 \quad 203 \quad 1950$ ${ }^{235} \mathrm{U}$, and ${ }^{238} \mathrm{U}$

${ }^{a}$ Represents depleted uranium; ${ }^{234} \mathrm{U}$ content assumed to be $0.0005 \%$ by mass.

${ }^{b}$ Represents unprocessed natural uranium; ${ }^{234} \mathrm{U}$ content assumed to be $0.0057 \%$ by mass.

${ }^{c}$ Derivations of air concentrations of uranium based on relative contents of ${ }^{234} \mathrm{U}$ and ${ }^{235} \mathrm{U}$ typically found in uranium enriched by the gaseous diffusion process.
} 


\subsection{Action Levels Based on Urinary Uranium}

Action levels based on the concentration of uranium in urine depend on the exposure conditions, including the form of inhaled uranium and the time-course of exposure relative to the time of collection of the urine sample. If the form of the radionuclide or pattern of exposure is not known, worst-case assumptions are made.

Interpretation of routine urinary uranium measurements becomes increasingly difficult as the sampling interval is widened. In the following it is assumed that urinary uranium measurements are made routinely at intervals no greater than 3 months. Also, it is assumed that the site bioassay program has been designed as far as feasible to avoid substantial underestimates of the average rate of urinary excretion of uranium for chronically exposed workers (see Section 4). Suppose, for example, that a worker is chronically exposed to moderately soluble uranium and a 24-h urine sample is collected $48-72 \mathrm{~h}$ after the last potential exposure. Then the average urinary excretion level could be assumed to be twice the measured value based on model predictions discussed in Section 4, or adjustment of the measured value could be made on the basis of site-specific information as discussed in Section 4. If a urine sample is a composite of several samples taken at different times of day during a work week, no adjustment of the measured value would be needed.

Designers of a monitoring program for uranium should keep in mind that urinary uranium is a reflection of the amount of uranium reaching the systemic circulation and may not be a reliable indicator of the content of uranium in the lungs. In situations where airborne uranium is likely to include a relatively insoluble component, the monitoring program should supplement urinary measurements with regular fecal measurements, external chest measurements, or both.

\subsubsection{Action Levels for Urinary Uranium for Inhalation of an Unknown Form of Uranium}

Tables 3.13 and 3.14 can be used to estimate the maximum concentration of uranium in the kidneys based on an elevated level of uranium in a routine urine sample, provided sampling is performed at least quarterly.

Regardless of the form of inhaled uranium or the pattern of exposure during a period no greater than $3 \mathrm{mo}$, the concentration of uranium in the kidneys in units of $\mu \mathrm{g} \mathrm{U/g}$ kidney is predicted to be no more than 30 times the concentration in urine in units of $\mu \mathrm{g} \mathrm{U} / \mathrm{mL}$ urine (Tables 3.13 and 3.14). The investigation level of $0.3 \mu \mathrm{g} \mathrm{U} / \mathrm{g}$ kidney corresponds to $(0.3 \mu \mathrm{g} / \mathrm{g}) /(30 \mu \mathrm{g} / \mathrm{g}$ per $\mu \mathrm{g} / \mathrm{mL})=0.01 \mu \mathrm{g} / \mathrm{mL}$ urine or $10 \mu \mathrm{g} \mathrm{U} / \mathrm{L}$ urine. The immediate action level $1.0 \mu \mathrm{g} \mathrm{U} / \mathrm{g}$ kidney corresponds to $33 \mu \mathrm{g} \mathrm{U} / \mathrm{L}$ urine.

Assignment of radiologically based action levels for an unknown form of uranium is complicated by the fact that relatively low concentrations of uranium in urine do not preclude the possibility of intake of elevated quantities of insoluble uranium and buildup of activity in the lungs. If the presence of an insoluble component is known or suspected, urinary uranium data should be supplemented with regular fecal measurements, external chest measurements, or both. 
The following calculations are based on the assumption that either: (a) the presence of a significant insoluble component of airborne uranium has been eliminated by in vitro solubility tests, or (b) chest measurements made at intervals of at most a few months do not indicate accumulation of uranium in the chest. In effect, it is assumed that airborne uranium is predominantly in soluble or moderately soluble form.

Suppose that routine measurements are made $\mathrm{T}$ days apart and the estimate of 24-h urinary uranium based on the present measurement is X Bq. Four different exposure possibilities are considered, and the investigation level is taken as the most restrictive of these cases:

Case 1 - Acute inhalation of uranium of Type $\mathrm{F}$

Case 2 - Acute inhalation of uranium of Type $\mathrm{M}$

Case 3 - Continuous inhalation of uranium of Type $\mathrm{F}$

Case 4 - Continuous inhalation of uranium of Type M.

As discussed earlier in this report, the exposure pattern indicated in Cases 3 and 4 does not occur in the workplace because the worker is removed from exposure at least three-fourths of the time. However, the assumption of continuous exposure may be used as a surrogate for chronic occupational intake for purposes of projecting accumulation of activity in tissues and radiation doses and evaluating bioassay data.

Dose coefficients $D_{F}$ and $D_{M}$ for ${ }^{234} U$ of Type $F$ and Type $M$, respectively, are used in the calculation as a conservative approach because these coefficients are slightly higher than corresponding values for ${ }^{235} \mathrm{U}$ and ${ }^{238} \mathrm{U}$ (Table 3.16). For Cases 1 and 2, the highest calculated uranium intakes and hence the highest calculated radiation doses result if the exposure is assumed to have occurred $\mathrm{T}$ days earlier, i.e., soon after collection of the previous urine sample. This is because the ICRP models predict that fractional daily excretion of uranium in urine declines monotonically with time after an acute inhalation intake (see Tables 3.7 and 3.8), and the intake estimated from a urine measurement of $\mathrm{X} \mathrm{Bq}$ is greatest if $\mathrm{X}$ is assumed to represent the smallest feasible fraction of intake. Denote by $A_{F}$ and $A_{M}$ the model predictions of fractional urinary excretion of intake $T$ days after acute intake of uranium of Type $F$ and Type $M$, respectively. A candidate investigation level in terms of 24-h urinary uranium based on Case 1 is the value $\mathrm{X}_{1}(\mathrm{~Bq})$ such that:

$$
\begin{aligned}
& D_{F} X_{1} / A_{F}=0.02(S v) \text {, or } \\
& X_{1}=0.02 A_{F} / D_{F} .
\end{aligned}
$$

Similarly, a candidate investigation level $\mathrm{X}_{2}$ based on Case 2 is

$$
\mathrm{X}_{2}=0.02 \mathrm{~A}_{\mathrm{M}} / \mathrm{D}_{\mathrm{M}} .
$$

For Cases 3 and 4, candidate investigation levels $X_{3}$ and $X_{4}$ in terms of 24-h urinary uranium are based on the dose coefficients $D_{F}$ and $D_{M}$ and the fraction of daily intake $C_{F}$ and $C_{M}$ excreted during day $\mathrm{T}$ after the beginning of continuous intake (see Tables 3.10 and 3.11). For an investigation level to be reached the annual intake assuming continuous exposure for $365 \mathrm{~d}$ 
would have to correspond to a committed effective dose of $0.02 \mathrm{~Sv}$. For inhalation of Type F material this means that

$$
\begin{aligned}
& 365 \mathrm{D}_{\mathrm{F}} \mathrm{X}_{3} / \mathrm{C}_{\mathrm{F}}=0.02 \text {, or } \\
& \mathrm{X}_{3}=0.02 \mathrm{C}_{\mathrm{F}} / 365 \mathrm{D}_{\mathrm{F}} .
\end{aligned}
$$

Similarly, for inhalation of Type M material this means that

$$
\mathrm{X}_{4}=0.02 \mathrm{C}_{\mathrm{M}} / 365 \mathrm{D}_{\mathrm{M}}
$$

Therefore, in terms of 24-h urinary uranium, the investigation level is the minimum of these four values:

$$
\begin{aligned}
& \mathrm{X}_{1}=0.02 \mathrm{~A}_{\mathrm{F}} / \mathrm{D}_{\mathrm{F}} \\
& \mathrm{X}_{2}=0.02 \mathrm{~A}_{\mathrm{M}} / \mathrm{D}_{\mathrm{M}} \\
& \mathrm{X}_{3}=0.02 \mathrm{C}_{\mathrm{F}} / 365 \mathrm{D}_{\mathrm{F}} \\
& \mathrm{X}_{4}=0.02 \mathrm{C}_{\mathrm{M}} / 365 \mathrm{D}_{\mathrm{M}} .
\end{aligned}
$$

The fractions $A_{F}$ and $A_{M}$ based on acute intake of Types $F$ and $M$ are taken from Tables 3.7 and 3.8, respectively. The fractions $\mathrm{C}_{\mathrm{F}}$ and $\mathrm{C}_{\mathrm{M}}$ based on chronic intake of Type $\mathrm{F}$ and $\mathrm{M}$ are taken from Tables 3.10 and 3.11, respectively. The dose coefficients $\mathrm{D}_{\mathrm{F}}$ and $\mathrm{D}_{\mathrm{M}}$ are both taken from Table 3.16. For example, if measurements are made monthly $(T=30 \mathrm{~d})$, the four values $\mathrm{X}_{1}, \mathrm{X}_{2}$, $\mathrm{X}_{3}$, and $\mathrm{X}_{4}$ are as follows:

$$
\begin{aligned}
& X_{1}=\left(0.02 \times 6.6 \times 10^{-4}\right) / 6.4 \times 10^{-7}=21 \mathrm{~Bq} \\
& X_{2}=\left(0.02 \times 2.6 \times 10^{-4}\right) / 2.1 \times 10^{-6}=2.6 \mathrm{~Bq} \\
& X_{3}=(0.02 \times 0.25) /\left(365 \times 6.4 \times 10^{-7}\right)=21 \mathrm{~Bq} \\
& X_{4}=(0.02 \times 0.037) /\left(365 \times 2.1 \times 10^{-6}\right)=0.97 \mathrm{~Bq} .
\end{aligned}
$$

The minimum of these four values, $0.97 \mathrm{~Bq}$, is the investigation level in terms of 24-h urinary uranium. Expressed in terms of the concentration of uranium in urine, the investigation level is $0.97 \mathrm{~Bq} / 1.6 \mathrm{~L}=0.6 \mathrm{~Bq} / \mathrm{L}$, where 1.6 L is the reference value for the volume of urine excreted per day.

The immediate action level based on radiological reference guidance can be calculated in the same way, with the committed effective dose $0.02 \mathrm{~Sv}$ replaced by $0.05 \mathrm{~Sv}$. As a result of the 2.5 times higher target dose, the immediate action level is 2.5 times higher than the investigation level, or:

$$
2.5 \times 0.6 \mathrm{~Bq} / \mathrm{L}=1.5 \mathrm{~Bq} / \mathrm{L} \text {. }
$$

For any sampling interval between $1 \mathrm{wk}$ and $3 \mathrm{mo}$, the radiologically based investigation or immediate action level for an uncertain form of uranium based on urinary uranium is determined by exposure Case 4 (continuous inhalation of Type $\mathrm{M}$ material), provided the possibility of relatively insoluble uranium or buildup of uranium in the chest has been eliminated. 
Investigation and immediate action levels based on Case 4 do not depend strongly on the sampling interval provided $\mathrm{T}$ is at least $1 \mathrm{wk}$. Therefore, the investigation level $0.6 \mathrm{~Bq} / \mathrm{L}$ and immediate action level $1.5 \mathrm{~Bq} / \mathrm{L}$ are adopted for uncertain forms of uranium and any sampling interval up to 3 mo.

The derived action levels for an unknown form of airborne uranium based on urinary excretion measurements are summarized in Table 5.4.

Table 5.4 Investigation and immediate action levels for urine for application to cases in which the form of airborne uranium is not known ${ }^{a}$

\begin{tabular}{lcc}
\hline Level & $\begin{array}{c}\text { Mass concentration } \\
\text { in urine } \\
(\boldsymbol{\mu g} / \mathbf{L})\end{array}$ & $\begin{array}{c}\text { Activity concentration } \\
\text { in urine } \\
(\mathbf{B q} / \mathbf{L})\end{array}$ \\
\hline Investigation level & 10 & $0.6^{b}$ \\
Immediate action level & 33 & $1.5^{b}$ \\
\hline
\end{tabular}

\footnotetext{
${ }^{a}$ Assuming urine sampling is performed at least quarterly.

${ }^{b}$ It is assumed that the presence of a relatively insoluble form of airborne uranium is considered unlikely in view of in vitro solubility tests or that reasonably frequent chest measurements do not indicate accumulation of uranium in the chest.
}

\subsubsection{Action Levels for Urinary Uranium for Inhalation of a Reasonably Well Characterized Form of Uranium}

When the form of inhaled uranium is reasonably well characterized, investigation and immediate action levels based on urinary uranium may be calculated from the appropriate table in Section3. The method of derivation of action levels in this case is the same as described above for an unknown form of airborne uranium except that one limits attention to a specific form of uranium rather than considering alternate forms and taking the minimum derived value.

Example 5.3. Suppose that a worker is chronically exposed to low levels of airborne uranyl nitrate confirmed by in vitro testing to be highly soluble in simulated lung fluid, and there is no reason to suspect intake of other forms of uranium. Suppose further that urine measurements are made monthly. The chemically based investigation and immediate action levels can be derived from Table 3.14, which provides kidney to urine concentration ratios for continuous intake of any form of uranium. According to Table 3.14, the kidney to urine concentration ratio at $30 \mathrm{~d}$ would be 7.9. The investigation level of $0.3 \mu \mathrm{g} \mathrm{U} / \mathrm{g}$ kidney corresponds to:

$$
0.3 \mu \mathrm{g} / \mathrm{g} / 7.9 \mu \mathrm{g} / \mathrm{g} \text { per } \mu \mathrm{g} / \mathrm{mL}=0.038 \mu \mathrm{g} / \mathrm{mL} \text { urine or } 38 \mu \mathrm{g} \mathrm{U} / \mathrm{L} \text { urine. }
$$

The immediate action level $1.0 \mu \mathrm{g} \mathrm{U} / \mathrm{g}$ kidney corresponds to $127 \mu \mathrm{g} \mathrm{U} / \mathrm{L}$ urine. Table 3.10, which addresses continuous intake of uranium of Type F, can be used to derive the radiologically 
based investigation and immediate action levels. The radiologically based investigation level of urinary uranium would be:

$$
(0.02 \times 0.25) /\left(365 \times 6.4 \times 10^{-7}\right)=21 \mathrm{~Bq} / \mathrm{d},
$$

where

0.25 is the fraction of daily intake excreted in urine on Day 30 after the start of intake, and

$6.4 \times 10^{-7} \mathrm{~Sv} / \mathrm{Bq}$ is the dose coefficient for inhalation of uranium of Type F.

This corresponds to an activity concentration in urine of:

$$
21 \mathrm{~Bq} \mathrm{~d}^{-1} / 1.6 \mathrm{~L}_{\text {urine }} \mathrm{d}^{-1}=13 \mathrm{~Bq} / \mathrm{L} \text {. }
$$

The radiologically based immediate action level would be 2.5 times higher or $33 \mathrm{~Bq} / \mathrm{L}$.

\subsubsection{Action Levels for Urinary Uranium for Intake through a Wound}

Uranium can enter the systemic circulation through a puncture wound or by penetration through burned, scraped, or even intact skin. In general, this type of exposure must be limited through enforcement of safe work practices rather than through numerical guidelines for uranium concentrations in the work environment or bioassay. Nevertheless, it is important to monitor a worker who has been exposed to uranium through a wound or intact skin to determine whether removal from further exposure or medical intervention is indicated.

Depending on the information available, Table 3.5 and Table 3.6 might be used to estimate the rate of transfer of uranium from a wound or skin to blood on the basis of urinary excretion measurements. If there is no evidence of intake of uranium by inhalation or ingestion, the rate of transfer of uranium from the wound to blood can be estimated from a series of urine samples taken after the wound incident. A rapid fall in the urinary excretion rate in the days following the incident suggests fast mobilization of the uranium from the wound to blood, as may occur after a soluble form of uranium enters the body through a puncture wound. A slowly declining, constant, or increasing rate of urinary excretion over an extended period indicates the presence of a less soluble form of uranium.

Example 5.4. A worker involved in fuel fabrication for a research reactor receives a puncture wound from an object contaminated with highly enriched uranium with specific activity estimated as $2 \times 10^{6} \mathrm{~Bq} / \mathrm{g}$ [see Equation 5.2]. He is removed from further exposure. The uranium content of 24-h urine samples is determined for Days $1(0-24 \mathrm{~h}), 2,3,5,7,15,20$, and 30 after the incident. Measured values for these eight days are 5000, 235, 120, 140, 100, 90, 30, and $18 \mathrm{~Bq}$, respectively. The measurements are plotted (Figure 5.3), and it is determined that the excretion pattern over time is reasonably similar to that given in Table 3.5 (see Column 2) for the case of acute uptake of uranium to blood at time zero. Based on the assumption of acute uptake to blood, total uptake is estimated from data for each 24-h observation period by dividing the 24-h excretion value by the fraction of uptake indicated for the corresponding day in Table 3.5. For example, 24-h excretion on Day 2 is $235 \mathrm{~Bq}$, and Table 3.5 indicates that about $2.3 \%$ of the total uptake would be excreted on Day 2, giving estimated uptake of 235/0.023 = 10,200 Bq. 
Estimates derived in this way for Days 1, 3, 5, 7, 15, 20, and 30 are 7810, 6670, 9330, 8330, 14800,7140 , and $7830 \mathrm{~Bq}$, respectively. The average of the eight estimates of uptake to blood is $\sim 9000 \mathrm{~Bq}$. Based on a specific activity of $2 \times 10^{6} \mathrm{~Bq} / \mathrm{g}$, the mass of uranium absorbed to blood is:

$$
9000 \mathrm{~Bq} / 2 \times 10^{6} \mathrm{~Bq} / \mathrm{g}=0.0045 \mathrm{~g}=4500 \mu \mathrm{g} .
$$

According to Table 3.5, the kidney content at $1 \mathrm{~d}$ after acute uptake to blood is $11 \%$ of the uptake or

$$
0.11 \times 4500 \mu \mathrm{g}=495 \mu \mathrm{g} .
$$

The concentration of uranium in the kidneys at this time would be approximately

$$
495 \mu \mathrm{g} \mathrm{U} / 310 \mathrm{~g} \text { kidney }=1.6 \mu \mathrm{g} \mathrm{U} / \mathrm{g} \text { kidney, }
$$

which exceeds the primary chemical reference guidance level of $1.0 \mu \mathrm{g} \mathrm{U} / \mathrm{g}$ kidney. Based on the retention values for kidneys given in Table 3.5, the kidney concentration would fall below $1.0 \mu \mathrm{g} \mathrm{U} / \mathrm{g}$ kidney within the next two weeks. From Table 3.15, the dose coefficient for intravenous injection of ${ }^{234} \mathrm{U}$ (the most conservative of the coefficients for ${ }^{234} \mathrm{U},{ }^{235} \mathrm{U}$, and ${ }^{238} \mathrm{U}$ ) is $2.3 \times 10^{-6} \mathrm{~Sv} / \mathrm{Bq}$. The projected effective dose from the intake is:

$$
9000 \mathrm{~Bq} \times 2.3 \times 10^{-6} \mathrm{~Sv} / \mathrm{Bq}=0.021 \mathrm{~Sv} .
$$

This exceeds the primary radiological reference guidance level $(0.02 \mathrm{~Sv})$ for intake during any 1 y period. The worker should not return to uranium work areas for about a year.

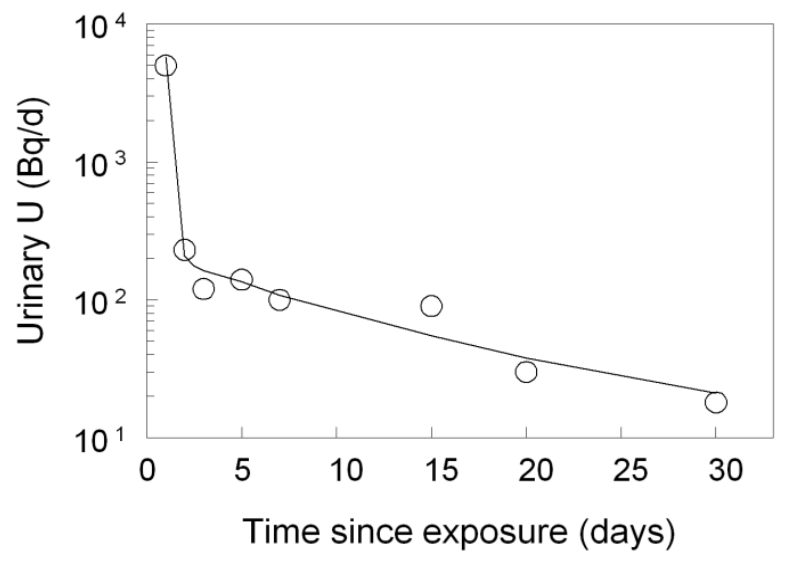

Figure 5.3 Pattern of change with time in urinary uranium for the hypothetical worker in Example 5.4. Curve is model fit to measured values (circles) based on acute uptake of uranium to blood at time zero (see Table 3.5). 
Example 5.5. A worker receives an injury that leaves a small piece of depleted uranium metal embedded in muscle tissue. A decision is made not to remove the metal surgically unless urinary uranium measurements indicate the need for intervention at some point based, for example, on the general reference guidance given in Table 1.1. Periodic urine measurements over the first $2 \mathrm{y}$ after the incident indicate a nearly constant urinary excretion rate of about $8(6-10) \mu \mathrm{g} \mathrm{U} / \mathrm{d}$, or roughly $3 \mathrm{mg} / \mathrm{y}$ (Figure 5.4). The steady rate of urinary excretion of uranium suggests a nearly constant rate of migration of uranium from the embedded metal to blood, estimated from the systemic model for uranium to be nearly the same as the urinary excretion rate $(\sim 3 \mathrm{mg} / \mathrm{y})$.

At $2 \mathrm{y}$ after intake the uranium concentration in the kidneys in units of $\mu \mathrm{g} \mathrm{U} / \mathrm{g}$ kidney is predicted on the basis of Table 3.14 to be about 10 times the concentration of uranium in urine in units of $\mu \mathrm{g} \mathrm{U} / \mathrm{mL}$ urine. In this case the nearly constant concentration in urine is about $(8 \mu \mathrm{g} \mathrm{U} / \mathrm{d}) /(1600 \mathrm{~mL}$ urine $/ \mathrm{d}) \sim 0.005 \mu \mathrm{g} \mathrm{U} / \mathrm{mL}$. Therefore, the concentration of uranium in the kidneys is estimated as:

$$
10(\mu \mathrm{g} \mathrm{U} / \mathrm{g} \text { kidney/ } \mu \mathrm{g} \mathrm{U} / \mathrm{mL}) \times 0.005 \mu \mathrm{g} \mathrm{U} / \mathrm{mL} \text { or } 0.05 \mu \mathrm{g} \mathrm{U} / \mathrm{g} \text { kidney. }
$$

This is well below the investigation level of $0.3 \mu \mathrm{g} \mathrm{U} / \mathrm{g}$ kidney based on chemical toxicity. For evaluation of the potential radiological hazard, effective dose coefficients given in Table 3.15 in units of $\mathrm{Sv} / \mathrm{g}$ are used to derive an effective dose coefficient $\mathrm{E}$ for the case of direct input of depleted uranium to blood, based on the assumption that depleted uranium consists of $0.25 \%$ ${ }^{235} \mathrm{U}, 0.0005 \%{ }^{234} \mathrm{U}$, and $99.7495 \%{ }^{238} \mathrm{U}$ :

$$
\mathrm{E}_{\mathrm{DU}}=(0.000005 \times 530)+(0.0025 \times 0.17)+(0.997495 \times 0.026)=0.029 \mathrm{~Sv} / \mathrm{g} .
$$

The level of input of $\mathrm{U}$ to blood required to yield the radiological criterion for investigative actions is:

$$
0.02 \mathrm{~Sv} \mathrm{y}^{-1} / 0.029 \mathrm{~Sv} \mathrm{~g}^{-1}=0.69 \mathrm{~g} / \mathrm{y}=690 \mathrm{mg} / \mathrm{y},
$$

which is about 230 times the estimated rate of migration of uranium from the embedded metal. Thus, medical intervention is not indicated in this case.

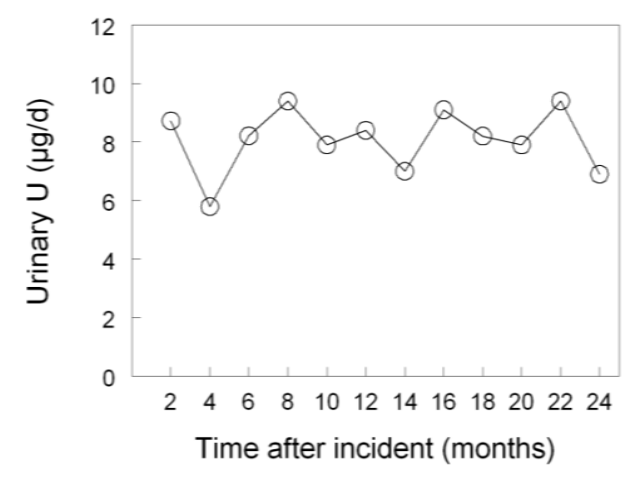

Figure 5.4 Urinary data for the hypothetical case described in Example 5.5. 
The systemic model described in Section 3 may be used in conjunction with a wound model that predicts the rate of mobilization of uranium from a wound to blood, but in any event it is important to continue to monitor the actual rate of mobilization of uranium to blood as reflected in urinary excretion measurements. The reader is referred to NCRP Report No. 156 (2006) for information on the behavior of uranium and other radionuclides in wounds and a description of a model depicting idealized rates of mobilization of activity to blood. Experimental data on the rate of penetration of uranium through burned, scraped, or intact skin and references to related studies can be found in papers by de Rey et al. 1983, Lopez et al. 2000, and Petitot et al. 2007.

\subsection{Action Levels Based on Measurement of Uranium in Feces}

In the case of inhalation of uranium in relatively insoluble form, with no significant soluble component, the radiation dose to the lungs is the main concern. For such forms there will generally be little deposition of uranium in the kidneys because of the low level of absorption of uranium to blood. Fecal excretion measurements may be made in conjunction with urinary excretion measurements to examine the possibility of inhalation of an insoluble form of uranium or to estimate radiation doses from such an exposure.

Radiologically based action levels for fecal uranium are applicable in cases where inhalation of a relatively insoluble form of uranium is known or suspected. Inhalation of a relatively insoluble form of uranium might be indicated, for example, by published solubility data for the type of material being handled, by in vitro solubility measurements of the specific material to which workers are thought to be exposed, by indications of buildup of uranium in the chest based on external measurements, or by determination of the ratio of the rates of fecal and urinary excretion of uranium in chronically exposed workers. A relatively insoluble form of uranium is indicated if the fecal excretion rate is more than an order of magnitude greater than the urinary excretion rate.

Radiologically based action levels for fecal uranium are determined by the same general approach used to derive radiologically based action levels for urinary uranium, with urinary excretion rates replaced in the computations by fecal excretion rates. The approach is illustrated by the following hypothetical case.

Example 5.6. A group of workers is exposed daily to an airborne uranium compound generally considered to be soluble or, at worst, moderately soluble in the lungs. However, routine measurements of urinary uranium $30 \mathrm{~d}$ after the start of exposure are much lower than predicted from air monitoring data if inhalation of either Type $\mathrm{F}$ or Type $\mathrm{M}$ material is assumed. Fecal measurements are made, and it is found that daily fecal excretion in the workers is about two orders of magnitude greater than daily urinary excretion. It is concluded that all or nearly all of the airborne uranium is relatively insoluble (Type $\mathrm{S}$ ). The investigation level corresponds to a fecal excretion rate of:

$$
(0.02 \times 0.43) /\left(365 \times 6.8 \times 10^{-6}\right)=3.5 \mathrm{~Bq} / \mathrm{d},
$$

where

$0.02 \mathrm{~Sv}$ is the dosimetric criterion for an investigation level, 
0.43 is the fraction of daily intake projected to be excreted in feces on Day 30 after the start of exposure assuming Type $\mathrm{S}$ material (Table 3.12), and

$6.8 \times 10^{-6} \mathrm{~Sv} / \mathrm{Bq}$ is the inhalation dose coefficient for ${ }^{234} \mathrm{U}$ of Type $\mathrm{S}$ (Table 3.16).

Assuming that the mass of feces excreted per day is $150 \mathrm{~g}$, the investigation level in terms of the concentration of uranium in feces is:

$$
3.5 \mathrm{~Bq} \mathrm{~d}^{-1} / 150 \mathrm{~g} \mathrm{~d}^{-1}=0.023 \mathrm{~Bq} / \mathrm{g} \text { feces. }
$$

The immediate action level corresponds to a fecal excretion rate of:

$$
(0.05 \times 0.43) /\left(365 \times 6.8 \times 10^{-6}\right)=8.7 \mathrm{~Bq} / \mathrm{d} .
$$

In terms of the concentration of uranium in feces the immediate action level is:

$$
\text { 8.7 } \mathrm{Bq} \mathrm{d}^{-1} / 150 \mathrm{~g} \mathrm{~d}^{-1} \sim 0.058 \mathrm{~Bq} / \mathrm{g} \text { feces. }
$$

The investigation and immediate action levels derived above for a 30-d interval between measurements turns out to be relatively insensitive to the length of time between routine measurements. This is because the predicted fraction of inhaled uranium of Type $\mathrm{S}$ excreted daily in feces quickly approaches the deposition fraction in the respiratory tract, excluding the anterior nasal passages ( $\sim 0.48$ for the particle size $5 \mu \mathrm{m}$ AMAD) (Table 3.12). Therefore, the action levels derived above are adopted (after rounding) as action levels for fecal uranium for cases in which a high ratio (>30) of daily fecal uranium to daily urinary uranium is determined.

Rounded investigation and immediate action levels based on fecal measurements are listed in Table 5.5.

Table 5.5 Investigation and immediate action levels for feces for cases in which chronic inhalation of a relatively insoluble form of uranium is known or suspected

\begin{tabular}{lc}
\hline \multicolumn{1}{c}{ Level } & $\begin{array}{c}\text { Activity concentration in feces } \\
(\mathbf{B q} / \mathbf{g})\end{array}$ \\
\hline Investigation level & 0.025 \\
Immediate action level & 0.06 \\
\hline
\end{tabular}

\subsection{Action Levels Based on External Measurement of Uranium in the Chest}

External measurements over the chest are used to detect accumulation of uranium in the lungs. The preferred detector is a germanium detector (WHO, 2001), but sodium iodide and phoswich detectors have also been used (ATSDR, 1999). The ${ }^{235} \mathrm{U}$ activity in the lungs is estimated from measurement of photon emissions from ${ }^{235} \mathrm{U}(186 \mathrm{keV})$. In some measurement systems the ${ }^{238} \mathrm{U}$ 
activity is also estimated by measurement of photon emissions from its daughter ${ }^{234} \mathrm{Th}(63 \mathrm{keV}$ and $93 \mathrm{keV}$ ), assuming that ${ }^{234} \mathrm{Th}$ is in equilibrium with ${ }^{238} \mathrm{U}$.

The minimum detectable activity (MDA) of ${ }^{235} \mathrm{U}$ or ${ }^{238} \mathrm{U}$ (i.e., ${ }^{234} \mathrm{Th}$ ) in the lungs depends on the type of detector used and the counting time. The MDA for a counting time of 45-60 min using a germanium detector is on the order of $4 \mathrm{~Bq}$ of ${ }^{235} \mathrm{U}$ and $100 \mathrm{~Bq}$ of ${ }^{238} \mathrm{U}$ (WHO 2001; Kramer et al. 2003).

The MDA expressed in terms of total uranium in the chest depends on the isotopic composition of uranium. For example, if ${ }^{235} \mathrm{U}$ is measured with a germanium detector and the counting time is $30 \mathrm{~min}$, the MDA may be on the order of $100-150 \mathrm{~Bq}$ for natural uranium but $40-70 \mathrm{~Bq}$ for $5 \%$ enriched uranium.

Default action levels for routine periodic in vivo lung measurements recommended in this report are based on the assumption that the estimated lung content represents steady-state conditions. That is, the rate of deposition of inhaled uranium in the lungs is assumed to equal the rate of loss of uranium from the lungs.

For purposes of deriving action levels for in vivo lung counts, the counts are assumed to represent activity in the 10 thoracic compartments of the HRTM shown in Figure 3.1: $\mathrm{AI}_{1}, \mathrm{AI}_{2}$, $\mathrm{AI}_{3}, \mathrm{bb}_{1}, \mathrm{bb}_{2}, \mathrm{bb}_{\mathrm{SEQ}}, \mathrm{BB}_{1}, \mathrm{BB}_{2}, \mathrm{BB}_{\mathrm{SEQ}}$, and $\mathrm{LN}_{\mathrm{TH}}$. Action levels are derived under the assumption that inhaled uranium is Type $\mathrm{M}$ material and the particle size is $5 \mu \mathrm{m}$ AMAD. This is a cautious assumption in that it yields a higher lung dose from a fixed amount of uranium in the lungs than if the material were assumed to be Type $S$. This is because Type $M$ and Type $S$ materials are predicted to have different time-dependent distributions in the lungs due to different transfer rates among respiratory compartments, and a larger portion of Type $\mathrm{M}$ than Type $\mathrm{S}$ material is predicted to reside in the bronchi (BB compartments in Figure 3.1) and bronchioles (bb compartments). Due to the relatively small masses of the bronchi and bronchioles, the dose per unit alpha activity within each of these regions is substantially higher than the dose per unit alpha activity within the relatively massive alveolar-interstitial region.

The HRTM predicts that under steady-state conditions the annual lung dose is approximately $8 \times 10^{-4} \mathrm{~Sv}$ per $\mathrm{Bq}$ of uranium of Type $\mathrm{M}$ in the lungs (range $7-9 \times 10^{-4} \mathrm{~Sv} / \mathrm{Bq}$, depending on the assumed isotopic composition of uranium). The lung dose represents about $92 \%$ of the effective dose for inhaled uranium of Type $\mathrm{M}$ and particle size $5 \mu \mathrm{m}$ AMAD. The investigation level should be the steady-state uranium content in the lungs corresponding to an annual lung dose of $0.92 \times 0.02 \mathrm{~Sv} / 0.12=0.153 \mathrm{~Sv}$, where $0.02 \mathrm{~Sv}$ is the limiting committed effective dose for an investigation level and 0.12 is the tissue weighting factor applied to lung in the derivation of effective dose. Therefore, the investigation level for an in vivo measurement of uranium in the lungs is $0.153 \mathrm{~Sv} / 8 \times 10^{-4} \mathrm{~Sv} \mathrm{~Bq}^{-1}=191 \mathrm{~Bq}$. This is rounded to $200 \mathrm{~Bq}$ in view of the sizable uncertainties in estimates of total uranium in the lungs.

The immediate action level is calculated in the same way, substituting $0.05 \mathrm{~Sv}$ for $0.02 \mathrm{~Sv}$ as the limiting annual committed effective dose. The derived immediate action level for the lung burden is $500 \mathrm{~Bq}$ when rounded to one significant digit. 
Investigation and immediate action levels for routine periodic external measurement of uranium in the chest are listed in Table 5.6.

Table 5.6 Investigation and immediate action levels for uranium in the chest based on routine periodic measurements

\begin{tabular}{lc}
\hline \multicolumn{1}{c}{ Level } & Total activity in the lungs $(\mathbf{B q})$ \\
\hline Investigation level & 200 \\
Immediate action level & 500 \\
\hline
\end{tabular}

Special chest measurements may be required for workers thought to have been acutely exposed to moderately soluble or relatively insoluble uranium, to determine whether work restrictions should be imposed. For example, if a chest measurement is made $10 \mathrm{~d}$ after acute inhalation of material thought to be highly insoluble, the immediate action level would be:

$$
(0.05 \times 0.058) / 6.8 \times 10^{-6}=426 \mathrm{~Bq},
$$

where,

$0.05 \mathrm{~Sv} / \mathrm{y}$ is the dosimetric criterion for an immediate action level, 0.058 is the fraction of intake predicted to be retained in the lungs $10 \mathrm{~d}$ after acute intake of Type $S$ material (Table 3.9), and

$6.8 \times 10^{-6} \mathrm{~Sv} / \mathrm{Bq}$ is the inhalation dose coefficient for ${ }^{234} \mathrm{U}$ of Type $\mathrm{S}$ (Table 3.16). 


\section{REFERENCES}

Akamine, A. U.; Duchen Silva, M. A.; Saiki, M.; Vasconcellos, M. B. A.; de Andrade, S. L.; Fulfaro, R. (2007). "Determination of uranium in human head hair of a Brazilian population group by epithermal neutron activation analysis." J. Radioanal. Nucl. Chem. 271:607-609.

Alberth, D. P; Szrom, F. (2007). "Operation Iraqi freedom depleted uranium bioassay screening program update.” Health Physics Program, U.S. Army Center for Health Promotion and Preventive Medicine, 2007 Force Health Protection Conference, August 6-10, 2007.

Alexander, R. E. (1974). Applications of Bioassay for Uranium. WASH-1251, Washington, DC: USAEC.

Alexander, R. E.; Neel, R. B.; Puskin, J. S.; Brodsky, A. (1986). Internal Dosimetry Model for Applications to Bioassay at Uranium Mines. NUREG-0874, U.S. Nuclear Regulatory Commission, Washington, DC.

André, S.; Métivier, H.; Auget, D.; Lantenois, G.; Boyer, M.; Masse, R. (1989). "Lung dissolution of uranium tetrafluoride in rats and baboons. Comparison with dissolution by alveolar macrophages in culture and chemical dissolution." Human Toxicol. 8:111-119.

Ansoborlo, E.; Chazel, V.; Houpert, P.; Hengé-Napoli, M. H.; Paquet, F.; Hodgson, A.; Stradling, N. (1998a). "Assessment of physico-chemical and biokinetic properties of uranium peroxide hydrate $\mathrm{UO}_{4} . "$ Health Phys. 75:389-397.

Ansoborlo, E.; Hodgson, A.; Stradling, G. N.; Hodgson, S.; Metivier, H.; Hengé-Napoli, M. H.; Jarvis, N.; Birchall, A. (1998b). "Exposure implications for uranium aerosols formed at a new laser enrichment facility: Application of the ICRP respiratory tract and systemic model." Radiat. Prot. Dosim. 79:23-27.

Ansoborlo, E; Chalabreysse, J.; Escallon, S.; Hengé-Napoli, M. H. (1990). "In vitro solubility of uranium tetrafluoride with oxidizing medium compared with in vivo solubility in rats." Int. J. Radiat. Biol. 58:681-689.

Ansoborlo, E.; Chazel, V.; Hengé-Napoli, M. H.; Pihet, P.; Rannou, A.; Bailey, M. R.; Tradling, N. (2002). "Determination of the physical and chemical properties, biokinetics, and dose coefficients of uranium compounds handled during nuclear fuel fabrication in France." Health Phys. 82:279-289.

Assistant Secretary of Defense. Guidance for depleted uranium (DU) bioassay urinalysis, attachment to the Memorandum, Policy for the Operation Iraqi Freedom depleted uranium (DU) medical management, HA Policy: 03-012; Department of Defense; 2003. (Available at http://www.ha.osd.mil/policies/2003/03-012.pdf.)

ATSDR (1999). Toxicological Profile for Uranium. U.S. Department of Health and Human Services. Public Health Service. Agency for Toxic Substances and Disease Registry. 
ATSDR (2001). "Summary report. Hair analysis panel discussion: Exploring the state of the science." Meeting held June 12-13, 2001 in Atlanta, GA. Agency for Toxic Substances and Disease Registry (available at http://www.atsdr.cdc.gov/hac/hair_analysis/pdfs.html).

Bailey, M.; Davis, K. (2002). "Estimations of kidney uranium concentrations from published reports of uranium intakes in man where subsequent effects on kidney function were monitored." Annexe A to The Health Hazards of Depleted Uranium Munitions Part II. The Royal Society, London. www.royalsoc.ac.uk/du.

Ballou, J. E.; Gies, R. A.; Case, A. C.; Haggard, D. L.; Bushbom, R. L.; Ryan, J. L. (1986). "Deposition and early disposition of inhaled ${ }^{233} \mathrm{UO}_{2}\left(\mathrm{NO}_{3}\right)_{2}$ and ${ }^{232} \mathrm{UO}_{2}\left(\mathrm{NO}_{3}\right)_{2}$ in the rat." Health Phys. 51:755-771.

Barber, J. M.; Forrest, R. D. (1995). "A study of uranium lung clearance at a uranium processing plant." Health Phys. 68:661-669.

Beau, P. G.; Chalabreysse, J. (1989). "Knowledge gained from bioassay data on some metabolic and toxicological features of uranium hexafluoride and its degradation products." Radiat. Prot. Dosim. 26:107-112.

Becker, J. S.; Burow, M.; Boulyga, S. F.; Pickhardt, C.; Hille, R.; Ostapczuk, P. (2002). "ICPMS determination of uranium and thorium concentrations and U-235/U-238 isotope ratios at trace and ultratrace levels in urine." Atomic Spectroscopy 23:177-182.

Becker, J. S.; Burow, M.; Zoriy, M. V.; Pickhardt, C.; Ostapczuk, P.; Hille, R. (2004). "Determination of uranium and thorium at trace and ultratrace levels in urine by laser ablation ICP-MS." Atomic Spectroscopy 25:197-202.

Becker, J. S. (2005). "Inductively coupled plasma mass spectrometry (ICP-MS) and laser ablation ICP-MS for isotope analysis of long-lived radionuclides." Int. J. Mass Spectrometry 242:183-195.

Bencze, K. ( 1994). "Determination of metals in human hair.” In Seiler, H.; Sigel, A.; Sigel, H., Handbook on Metals in Clinical and Analytical Chemistry. Boca Raton, FL. CRC Press, pp. 201-216.

Bentley, K. W.; Wyatt, J. H.; Wilson, D. J.; Dixon, R. J. (1982). "Uranium and plutonium in hair as an indicator of body burden in mice of different age and sex." Bull. Environ. Contam. Toxicol. 28:691-696.

Bhanti, D. P.; Malvankar, S. V.; Kotrappa, P. (1986). "Measurement of specific alpha radioactivity with respect to size for Kerala monazite sand using aerosol centrifuge." J. Nucl. Sci. Technol. 23:1023-1025. 
Boback, M. W. (1975). "A review of uranium excretion and clinical urinalysis data in accidental exposure cases." Proceedings of the Conference on Occupational Health Experience with Uranium, pp. 226-243. Arlington, Virginia, April 28-30, 1975, ERDA 93, U.S. Energy Research and Development Administration.

Bogard, J. S. (1996). Review of Uranium Bioassay Techniques. ORNL 5867. Oak Ridge National Laboratory, Oak Ridge Tennessee.

Bouvier-Capely, C.; Ritt, J.; Baglan, N; Cossonnet, C. (2004). "Potentialities of mass spectrometry (ICP-MS) for actinides determination in urine." Appl. Radiat. Isotopes 60:629-633.

Brown, S. H. (2008). “The new generation of uranium in situ recovery facilities: Design improvements should reduce radiological impacts relative to first generation uranium solution mining plants.” WM 08 Conference, February 25-March 1, 2008, Phoenix, Arizona; Paper \#8414.

Bush, W.; Ekenstam, G.; Janov, J.; Kuhn, E.; Ryjinski, M. (2001). "IAEA experience with environmental sampling at gas centrifuge enrichment plants in the European Union." Proceedings of the $42^{\text {nd }}$ Annual Meeting of the Institute of Nuclear Materials Management. IAEA-SM-367/10/04. Indian Wells, California.

Byrne, A. R.; Benedik, L. (1991). "Uranium content of blood, urine and hair of exposed and nonexposed persons determined by radiochemical neutron activation analysis, with emphasis on quality control." Sci. Total Environ. 107:143-157.

Canu, I. G.; Ellis, E. D.; Tirmarche, M. (2008). "Cancer risk in nuclear workers occupationally exposed to uranium - emphasis on internal exposure.” Health Phys. 94:1-17.

Centers for Disease Control and Prevention, National Center for Environmental Health, Third National Report on Human Exposure to Environmental Chemicals, National Health and Nutrition Examination Surveys (NHANES), July 2005. (Available at http://www.cdc.gov/exposurereport/results_01.htm.)

Cernichiari, E.; Brewer, R.; Myers, G. J.; Marsh, D. O.; Lapham, L. W.; Cox, C.; Shamlaye, C. F.; Berlin, M.; Davidson, P. W.; Clarkson, T. W. (1995). "Monitoring methyl mercury during pregnancy: Maternal hair predicts fetal brain exposure.” Neurotoxicology 16:705-710.

Cernichiari, E.; Myers, G. J.; Ballatori, N.; Zareba, G.; Vyas, J.; Clarkson, T. (2007). "The biological monitoring of prenatal exposure to methylmercury." Neurotoxicology 28:1015-1022.

Chalabreysse, J. (1970). "Etude et résultats d'examens effectués à la suite d'une inhalation de composés dits solubles d'uranium naturels." Radioprotection 5:pp. 1-17 and pp. 305-310.

Chalabreysse, J.; Beau, P. G.; Chevalier, C.; Jeanmaire, L.; Bataller, G.; Bérard, P.; Gibert, B. (1989). "French experience with uranium compounds." Radiat. Prot. Dosim. 26:49-56. 
Chazel, V.; Houpert, P.; Ansoborlo, E. (1998). "Effect of $\mathrm{U}_{3} \mathrm{O}_{8}$ specific surface area on in vitro dissolution, biokinetics, and dose coefficients." Radiat. Prot. Dosim. 79:39-42.

Chazel, V.; Houpert, P.; Hengé-Napoli, M. H.; Paquet, F.; Ansoborlo, E (2000a). "Experimental determination of the solubility of industrial UF 4 particles.” Radiat. Prot. Dosim. 92:289-294.

Chazel, V.; Houpert, P.; Ansoborlo, E.; Hengé-Napoli, M. H.; Paquet, F. (2000b). "Variation of solubility, biokinetics and dose coefficients of industrial uranium oxides according to specific surface area." Radiat. Prot. Dosim. 88:223-231.

Chou, C.-H. S. J.; Pohl, H.R.(2005). "Health effects classification and its role in the derivation of minimal risk levels: Renal effects." Regul. Toxicol. Pharm. 42:202-208.

Cook, N.; Holt, F. B. (1974). "The solubility of some uranium compounds in simulated lung fluid." Health Phys. 27:69-77.

Cooper, J. R.; Stradling, G. N.; Smith, H.; Ham, S. E. (1982). "The behaviour of uranium-233 oxide and uranyl-233 nitrate in rats." Int. J. Radiat. Biol. 41:421-433.

Damon, E. G.; Eidson, A. F.; Hahn, F. F.; Griffith, W. W.; Guilmette, R. A. (1984).

"Comparison of early lung clearance of yellowcake aerosols in rats with in vitro dissouton and IR analysis." Health Phys. 42:469-477.

Dennis, N. A.; Blauer, H. M.; Kent, J. E. (1982). "Dissolution fractions and half times of single source yellowcake in simulated lung fluids." Health Phys. 42:469-477.

de Rey, B. M.; Lanfranchi, H. E.; Cabrini, R. L. (1983). "Percutaneous absorption of uranium compounds." Environ. Res. 30:480-491.

DOE (1988). Health Physics Manual of Good Practices for Uranium Facilities. EGG-2530 UC41. Department of Energy, Idaho National Engineering Laboratory.

Dorrian, M. D.; Bailey, M. R. (1995). "Particle size distributions of radioactive aerosols measured in workplaces." Radiat. Prot. Dosim. 60:119-113.

Duport, P.; Robertson, R.; Ho, K.; Horvath, F. (1991). "Flow-through dissolution of uraniumthorium ore dust, uranium concentrate, uranium dioxide, and thorium alloy in simulated lung fluid." Radiat. Prot. Dosim. 38:121-133.

Eidson, A. F.; Mewhinney, J. A. (1980). "In vitro solubility of yellow cake samples from four uranium mills and implications for bioassay interpretation." Health Phys. 39:893-902.

Eidson, A. F. (1990). Biological Characterisation of Radiation Exposure and Dose Estimates for Inhaled Uranium Mining Effluents. NUREG/CR-5489 TI90 012914, U.S. Nuclear Regulatory Commission. 
Eidson, A. F. (1994). "The effect of solubility on inhaled uranium compound clearance: A review." Health Phys. 67:1-14.

Ellender, M. (1987). "The clearance of uranium after deposition of the nitrate and bicarbonate in two regions of the rat lung." Human Toxicol. 6:479-482.

Endo, A.; Yamaguchi, Y.; Eckerman, K. F. (2005). Nuclear Decay Data for Dosimetry Calculations - Revised Data of ICRP Publication 38, JAERI 1347, Japan Atomic Energy Research Institute.

Fisher, D. R.; Jackson, P. O.; Brodaczynski, G. G.; Scherpelz, R. I. (1982). Measurements of ${ }^{234} U,{ }^{238} U$, and ${ }^{230}$ Th in Excreta of Uranium Mill Crushermen. NUREG/CR 2503, PNL-4027, Pacific Northwest Laboratory, Richland, Washington.

Fisher, D. R; Swint, M. J.; Kathren, R. L. (1991). "Modified biokinetic model for uranium from analysis of acute exposure to UF6." Health Phys. 60:335-342.

Fisher, D. R.; Briant, J. K (1994). "Assessment of accidental intakes of uranyl acetylacetonate (UAA)." Radiat. Prot. Dosim. 53:263-267.

Foulkes, E. C. (1990). "The concept of critical levels of toxic heavy metals in target tissues." Crit. Rev. Toxicol. 20:327-339.

Galibin, G. P.; Parfenov, Y. D. (1971). "Inhalation study on metabolism of insoluble uranium compounds." In Walton, W. H., ed., Inhaled Particles 111. Vol. 1, 201-208. Old Woking Surrey, United Kingdom: Unwin Bros. Ltd.

Gilman, A. P.; Villeneuve, D. C.; Secours, V. E.; Yagminas, A. P.; Tracy, B. L.; Quinn, J. M.; Valli, V. E.; Moss, M. A. (1998). "Uranyl nitrate: 91-day toxicity studies in the New Zealand white rabbit.” Toxicol. Sci. 41:129-137.

Gonnen, R.; Kol, R.; Laichter, Y.; Marcus, P.; Halicz, L.; Karpas, Z. (2000). "Determination of uranium in human hair by acid digestion and FIAS-ICPMS." J. Radioanal. Nucl. Chem. 243:559-562.

Guilmette, R. A.; Parkhurst, M. A.; Miller, G.; Hahn, E. F.; Roszell, L. E.; Daxon, E. G.; Little, T. T.; Whicker, J. J.; Cheng, Y. S.; Traub, R. J.; Lodde, G. M.; Szrom, F.; Bihl, D. E.; Creek, K. L.; McKee, C. B. (Project Administrator) (2004). "Human health risk assessment of Capstone depleted uranium aerosols." Attachment 3 to the Capstone Summary Report. October 2004.

Hang, W.; Zhu, L. W.; Zhong, W. W.; Mahan, C. (2004). "Separation of actinides at ultra-trace level from urine matrix using extraction chromatography-inductively coupled plasma mass spectrometry.” J. Analyt. Atomic Spectrometry 19:966-972.

Harris, W. B. (1961). "The experimental clearance of uranium dust from the human body." In Davies, C. N., ed. Inhaled Particles and Vapors. Vol. I. London: Pergamon Press; 209-220. 
Harrison, J. D.; Metivier, H.; Leggett, R. W.; Nosske, D.; Paquet, F.; Phipps, A.; Taylor, D. (2001). "Reliability of the ICRP's dose coefficients for members of the public. II. Uncertainties in the absorption of ingested radionuclides and the effect on dose estimates." Radiat. Prot. Dosim. 95:295-308.

Hinners, T. A.; Terrill, W. J.; Kent, J. L.; Colucci, A. V. (1974). "Hair-metal binding." Environmental Health Perspectives 8:191-199.

Hodgson, A.; Moody, J. C.; Stradling, G. N.; Bailey, M. R.; Birchall A. (2000). Application of the ICRP Respiratory Tract Model to Uranium Compounds Produced During the Manufacture of Nuclear Fuel. NRPB Report M1156. Chilton, UK.

ICRP (1959). International Commission on Radiological Protection. Report of Committee 2 on Permissible Dose for Internal Radiation. ICRP Publication 2. Oxford: Pergamon Press.

ICRP (1977). International Commission on Radiological Protection. Recommendations of the International Commission on Radiological Protection. ICRP Publication 26. Oxford: Pergamon Press.

ICRP (1979). International Commission on Radiological Protection. Limits for Intakes of Radionuclides by Workers. ICRP Publication 30, Part 1. Oxford: Pergamon Press.

ICRP (1980). International Commission on Radiological Protection. Limits for Intakes by Workers. ICRP Publication 30, Part 2. Oxford: Pergamon Press.

ICRP (1981). International Commission on Radiological Protection. Limits for Intakes by Workers, ICRP Publication 30, Part 3. Oxford: Pergamon Press.

ICRP (1987). International Commission on Radiological Protection. Lung Cancer Risk from Indoor Exposures to Radon Daughters. ICRP Publication 50. Oxford: Pergamon Press.

ICRP (1988). International Commission on Radiological Protection. Limits for Intakes by Workers. ICRP Publication 30, Part 4. Oxford: Pergamon Press.

ICRP (1991). International Commission on Radiological Protection. 1990 Recommendations of the International Commission on Radiological Protection. ICRP Publication 60. Oxford: Pergamon Press.

ICRP (1993a). International Commission on Radiological Protection. Age-dependent Doses to Members of the Public from Intake of Radionuclides, Part 2, ICRP Publication 67. Oxford: Pergamon Press.

ICRP (1993b). International Commission on Radiological Protection. Protection Against Radon-222 at Home and at Work. ICRP Publication 65. Oxford: Pergamon Press. 
ICRP (1994a). International Commission on Radiological Protection. Human Respiratory Tract Model for Radiological Protection. ICRP Publication 66. Oxford: Pergamon Press.

ICRP (1994b). International Commission on Radiological Protection. Dose Coefficients for Intakes of Radionuclides by Workers. ICRP Publication 68. Oxford: Pergamon Press.

ICRP (1995a). International Commission on Radiological Protection. Age-dependent Doses to Members of the Public from Intake of Radionuclides, Part 3, ICRP Publication 69. Oxford: Pergamon Press.

ICRP (1995b). International Commission on Radiological Protection. Age-dependent Doses to Members of the Public from Intake of Radionuclides, Part 4, ICRP Publication 71. Oxford: Pergamon Press.

ICRP (2002a). International Commission on Radiological Protection. Supporting Guidance 3. Guide for the Practical Application of the ICRP Human Respiratory Tract Model. Oxford: Pergamon Press.

ICRP (2002b). International Commission on Radiological Protection. Basic Anatomical and Physiological Data for Use in Radiological Protection: Reference Values. ICRP Publication 89. Oxford: Pergamon Press.

ICRP (2006). International Commission on Radiological Protection. Human Alimentary Tract Model for Radiological Protection. ICRP Publication 100. Oxford: Pergamon Press.

ICRP (2008). International Commission on Radiological Protection. The 2007 Recommendations of the International Commission on Radiological Protection. ICRP Publication 103. Oxford: Pergamon Press.

Jackson, S. (1966). "Creatinine in urine as an index of urinary excretion rate." Health Phys. 12:843-850.

Kalkwarf, D. R. (1979). Solubility Classification of Airborne Products from Uranium Ores and Tailings Piles. NUREG/CR-0350, PNL-2870. Pacific Northwest Laboratory, Richland, Washington.

Karpas, Z.; Halicz, L.; Roiz, J.; Marko, R.; Katorza, E.; Lorber, A.; Goldbart, Z. (1996). "Inductively coupled plasma mass spectrometry as a simple, rapid, and inexpensive method for determination of uranium in urine and fresh water. Comparison with LIF." Health Phys. 71:879885 .

Karpas, Z.; Lorber, A.; Elish, P.; Marcus, P.; Roiz, J.; Marko, R.; Kol, R.; Brikner, D.; Halicz, L. (1998). "Uranium in urine - normalization to creatinine." Health Phys. 74:86-90.

Karpas, Z. (2001). “Uranium Bioassay - Beyond Urinalysis.” Health Phys. 81:460-463. 
Karpas, Z.; Lorber, A.; Sela, H.; Paz-Tal, O.; Hagag, Y.; Kurttio, P.; Salonen, L. (2005a). "Measurement of the U-234/U-238 ratio by MC-ICPMS in drinking water, hair, nails, and urine as an indicator of uranium exposure." Health Phys. 89:315-321.

Karpas, Z.; Paz-Tal, O.; Lorber, A.; Salonen, L.; Komulainen, H.; Auvinen, A.; Saha, H.; Kurttio, P. (2005b). "Urine, hair, and nails as indicators for ingestion of uranium in drinking water." Health Phys. 88:229-242.

Kathren, R. L.; Moore, R. H. (1986); “Acute accidental inhalation of U: A 38-year follow-up." Health Phys. 51:609-619.

Kathren, R. L.; Burklin, R. K. (2008). “Acute chemical toxicity of uranium.” Health Phys. 94:170-179.

Kotrappa, P.; Bhanti, D. P.; Jha, G. (1979). "Measurement of specific alpha radioactivity with respect to size for uranium ore dust using aerosol centrifuge." Health Phys. 36:738-740.

Kramer, G. H.; Hauck, B. M.; Allen, S. A.; Dantas, B. M.; Dantas, A. L.; Azeredo, A. (2003). "Lung counting: summing techniques to reduce the MDA." Health Phys. 85:220-227.

Krystek, P.; Ritsema, R. (2008). "An incident study about acute and chronic human exposure to uranium by high-resolution inductively coupled plasma mass spectrometry." Int. J. Hygiene Environ. Health, Jan 8, 2008 (Epub ahead of print).

Leach, L. J.; Yuile, C. L.; Hodge, H. C.; Sylvester, G. E.; Wilson, H. B. (1973). “A five-year inhalation study with natural uranium dioxide (UO2) dust-II. Post-exposure retention and biologic effects in the monkey, dog and rat." Health Phys. 25:239-258.

Leggett, R. W. (1989). "The behavior and chemical toxicity of uranium in the kidney: A reassessment." Health Phys. 57:365-383.

Leggett, R. W. (1992). “A generic age-specific biokinetic model for calcium-like elements.” Radiat. Prot. Dosim. 41:183-198.

Leggett, R. W. (1994). "Basis for the ICRP's age-specific biokinetic model for uranium." Health Phys. 67:589-610.

Leggett, R. W.; Harrison, J. D. (1995). "Fractional absorption of ingested U in humans." Health Phys. 68:484-498.

Leggett, R. W.; Eckerman, K. F.; Boice, J. D. (2005). “A respiratory model for uranium aluminide based on occupational data." J. Radiol. Prot. 25:1-12.

Luessenhop, A.J.; Gallimore, J. C; Sweet, W. H.; Struxness, E. G.; Robinson, J (1958). The toxicology in man of hexavalent uranium following intravenous administration." Amer. J. Roent. 79:83-100. 
López, R.; Díaz, S.; Ubios, A. M.; Cabrini, R. L. (2000). "Percutaneous toxicity of uranyl nitrate: its effect in terms of exposure area and time." Health Phys. 78:434-437.

Marco, R.; Katorza, E.; Gonen, R.; German, U.; Tshuva, A.; Pelled, O.; Paz-Tal, O.; Adout, A.; Karpas, Z. (2008). "Normalisation of spot urine samples to 24-h collection for assessment of exposure to uranium." Rad. Prot. Dosim. 130:213-223.

Maxell, S. L; Fauth, D. J. (2002). Rapid Actinide Column Extraction Methods for Bioassay Samples. WSRC-MS-2002-00997. Westinghouse Savannah River Company.

Maynard, E. A.; Hodge, H. C. (1949). "Studies of the toxicity of various uranium compounds when fed to experimental animals." In Voegetlin, C.; Hodge, H. C., ed., The Pharmocology and Toxicology of Uranium Compounds. National Nuclear Energy Service, Division VI, Vol. 1, 309376. New York: McGraw-Hill.

McDiarmid, M. A.; Engelhardt, S. M.; Dorsey, C. D.; Oliver, M.; Gucer, P.; Wilson, P. D.; Kane, R.; Cernich, A.; Kaup, B.; Anderson, L.; Hoover, D.; Brown, L.; Albertini, R.; Gudi, R.; Squibb, K. S. (2009). "Surveillance results of depleted uranium-exposed Gulf War I veterans: Sixteen years of follow-up." J. Toxicol. Environ. Health A. 72:14-29.

McLaughlin, D. A. (2005). Oak Ridge National Laboratory Internal Dosimetry Program Technical Basis Document, Revision 7, December 21, 2005.

Métivier, H.; Poncy, J. L.; Rateau, G., Stradling, G. N.; Moody, J. C.; Gray, S. A. (1992). "Uranium behaviour in the baboon after the deposition of a ceramic form of uranium dioxide and uranium octoxide in the lungs: implications for human exposure." Radioprotection 27:263-281.

Mohagheghi, A. H.; Shanks, S. T.; Zigmond, J. A.; Simmons, G. L.; Ward, S. L. A (2005). “A Survey of Uranium and Thorium Background Levels in Water, Urine, and Hair and Determination of Uranium Enrichments by ICP-MS." J. Radioanalyt. Nucl. Chem. 263:189-195.

Monleau, M.; De Meo, M.; Paquet, F.; Chazel, V.; Gerard Dumenil, G.; Donnadieu-Claraz, M. (2006). "Genotoxic and Inflammatory Effects of Depleted Uranium Particles Inhaled by Rats." Toxicological Sciences 89:287-295.

Moore, R. H.; Kathren R. L. (1985). “A World War II uranium hexafluoride inhalation event with pulmonary implications for today." J. Occup. Med. 27:753-756.

Morrow, P. E.; Gibb, F. R.; Beiter, H. D. (1972). "Inhalation studies of uranium trioxide.” Health Phys. 23:273-280.

Morrow, P. E.; Gelein, R. M.; Beiter, H. D.; Scott, J. B.; Picano, J. J.; Yuile, C. L. (1982).

"Inhalation and intravenous studies of $\mathrm{UF}_{6} / \mathrm{UO}_{2} \mathrm{~F}_{2}$ in dogs." Health Phys. 43:859-873. 
Morrow, P. E. (1984). "Biokinetics and toxicology of uranium.” In Moore, R. H., ed. Biokinetics and analysis of uranium in man. United States Uranium Registry, USUR-05, HEHF-47, 1984:E1-E27. Available from National Technical Information Service, 5285 Port Royal Road, Springfield, VA, 22151.

NCRP (1987). Use of Bioassay Procedures for Assessment of Internal Radionuclide Deposition, National Council on Radiation Protection and Measurements, NCRP Report No. 87. Bethesda, Maryland.

NCRP (2006). Development of a Biokinetic Model for Radionuclide-contaminated Wounds and Procedures for Their Assessment, Dosimetry and Treatment. NCRP Report No. 156. Bethesda, Maryland: National Council on Radiation Protection and Measurements.

NHANES (2005). Third National Report on Human Exposure to Environmental Chemicals. Centers for Disease Control, U.S. Department of Human and Health Services, Public Health Service, Atlanta, Georgia.

Ough, E. A.; Lewis, B. J.; Andrews, W. S.; Bennett, L. G. I.; Hancock, R. G. V.;

Scott, K. (2002). "An examination of uranium levels in Canadian Forces personnel who served in the Gulf War and Kosovo." Health Phys. 82:527-532.

Parrish, R. R.; Thirlwall, M.; Pickford, C.; Horstwood, M. S. A.; Gerdes, A.; Anderson, J.; Coggon, D. (2006). "Determination of ${ }^{238} \mathrm{U} /{ }^{235} \mathrm{U},{ }^{236} \mathrm{U} /{ }^{238} \mathrm{U}$ and uranium concentration in urine using SF-ICP-MS and MC-ICP-MS: An interlaboratory comparison.” Health Phys. 90:127-138.

Pellow, P. G.; Stradling, G. N.; Hodgson, A.; Fell, T. P.; Phipps, A.; Ellender, M. (1996). Biokinetics of Uranium Tributyl Phosphate in the Rat: Implications for Occupational Exposure. NRPB Report M682. Chilton, UK.

Petitot, F.; Felon, S.; Moreels, A. M.; Claraz, M.; Delissen, O.; Tourlonias, E.; Dhieux, B.; Maubert, C.; Paquet, F. (2007). "Incorporation and distribution of uranium in rats after a contamination on intact or wounded skin." Health Phys. 92:464-474.

Pomroy, C.; Noel, L. (1981). "Retention of uranium thorax burdens in fuel fabricators." Health Phys. 41:393-400.

Price, A. (1989). "Review of methods for assessment of intake of uranium by workers at BNFL Springfields.” Radiat. Prot. Dosim. 26:35-42.

Priest, N. D.; Howell, G. R.; Grenn, D.; Haines, J. W. (1982). "Uranium in bone - metabolic and autoradiographic studies in rat." Human Toxicol. 1:97-114.

Rich, B.; Hinnefeld, S.; Lagerquist, C.; Mansfield, W.; Munson, L.; Wagner, E.; Vallario, E. (1988). Health Physics Manual of Good Practices at Uranium Facilities. EGG-2530, UC-41, U.S. Department of Energy. 
Schieferdecker, H.; Dilger, H.; Doerfel, H. (1985). "Inhalation of U aerosols from $\mathrm{UO}_{2}$ fuel element fabrication." Health Phys. 48:29-48.

Schaumlöffel, D.; Giusti, P.; Zoriy, M. V.; Pickhardt, C.; Szpunar, J.; Lobinski, R.; Becker, S. J. (2005). "Ultratrace determination of uranium and plutonium by nano-volume flow injection double-focusing sector field inductively coupled plasma mass spectrometry (nFI-ICP-SFMS)." J. Analyt. Atomic Spectrometry 20:17-21.

Spoor, N. L.; Hursh, J. B. (1973). "Protection criteria." In Hodge, H. C.; Stannard, J. N.; Hursh, J. B.; Eds. Uranium, Plutonium, Transplutonic Elements: Handbook of Experimental Pharmacology, Vol. 36, Chap. 5., 241-270, Springer-Verlag, New York.

Squibb, K. S.; Leggett, R. W.; McDiarmid, M. (2005). "Prediction of renal concentrations of depleted uranium and radiation dose in Gulf War veterans with embedded shrapnel." Health Phys. 89:267-273.

Stopps, G. J.; Todd, M. (1982). The Chemical Toxicity of Uranium with Special Reference to Effects on the Kidney and the Use of Urine for Biological Monitoring. INFO-0074. Atomic Energy Control Board of Canada, Box 1046, Ottawa, K1P5S9.

Stradling, G. N.; Stather, J. W.; Strong, J. C.; Sumner, S. A.; Towndrow, C. G.; Moody, J. C.; Sedgwick, D.; Cooke, N. (1985). "The metabolism of some industrial uranium tetrafluorides after deposition in the rat lung." Human Toxicol. 4:159-168.

Stradling, G. N.; Stather, J. W.; Gray, S. A.; Moody, J. C.; Ellender, M., Hodgson, A.; Sedgwick, D.; Cooke, N. (1987). "Metabolism of uranium in the rat after inhalation of two industrial forms of ore concentrate: The implications for occupational exposure." Human Toxicol. 4:563-572.

Stradling, G. N.; Stather, J. W.; Price, A.; Cooke, N. (1989a). "Limits on intake and the interpretation of monitoring data for workers exposed to industrial uranium bearing dusts." Radiat. Prot. Dosim. 26:83-87.

Stradling, G. N.; Stather, J. W.; Strong, J. C.; Sumner, S. A.; Moody, J. C.; Towndrow, C. G.; Hodgson, A.; Sedgwick, D.; Cooke, N. (1989b). "Metabolism of an industrial $\mathrm{UO}_{2}$ dust after deposition in the rat lung." Human Toxicol. 4:563-572.

Stradling, G. N.; Hodgson, A.; Ansoborlo, E.; Berard, P.; Etherington, G.; Fell, T.; Rance, E.; Le Guen, B. (2002). Industrial Uranium Compounds: Exposure Limits, Assessment of Intake and Toxicity after Inhalation. NRPB Report W22. Chilton, UK.

Struxness, E. G.; Luessenhop, A. J.; Bernard, S. R.; Gallimore, J. C. (1956). "The distribution and retention of hexavalent uranium in man." Proceedings of International Conference on the Peaceful Uses of Atomic Energy, Vol. 10, pp. 186-195. United Nations, New York. 
Sula, M. J.; Carbaugh, E. H.; Bihl, D. E. (1989). Technical Basis for Internal Dosimetry at Hanford. PNL-6866, UC-41. Pacific Northwest Laboratory, Richland, Washington.

SuLu, Zhao Fu-Yao (1990). "Nephrotoxic limit and annual limit on intake for natural U." Health Phys. 58:619-623.

Sutton, M.; Burastero, S. R. (2004). "Uranium(VI) solubility and speciation in simulated elemental human biological fluids.” Chem. Res. Toxicol. 17:1468-1480.

Swift, J. A. (1996). "Morphology and histochemistry of human hair.” In Jolles, P.; Zahn, H.; Hoecker, H., Formation and Structure of Human Hair, 149-175. Birkhaueser, Basel, Switzerland.

Szrom, F., Alberth, D.P. (2007). "Operation Iraqi freedom depleted uranium bioassay screening program update.” Health Physics Program, U.S. Army Center for Health Promotion and Preventive Medicine, 2007 Force Health Protection Conference, August 6-10, 2007.

Todorov, T. I.; Ejnik, J. W.; Millick, F. G.; Centeno, J. A. (2007). “Chemical and histological assessment of depleted uranium in tissues and biological fluids." In Depleted Uranium Properties, Uses, and Health Consequences. Miller, A. C., ed. CRC Press, Boca Raton, Florida.

UNSCEAR (2000). Sources and Effects of Ionizing Radiation. United Nations Scientific Committee on the Effects of Atomic Radiation UNSCEAR 2000 Report to the General Assembly with Scientific annexes. New York: United Nations.

US Army Medical Command. Medical management of Army personnel exposed to depleted uranium (DU); OTSG/MEDCOM Policy Memo 07-022, 26 June 2007; Ft. Sam Houston, TX: Office of the US Army Surgeon General; 2007. (Available at http://www.pdhealth.mil/downloads/OTSG-MEDCOM_Policy_Memo_07-022.pdf.)

USEPA (1999a). Understanding Variation in Partition Coefficient, $K_{d}$ Values, Vol 1: The $K_{d}$ Model, Methods of Measurement, and Application of Chemical Reaction Codes. EPA 402-R-99004A. U.S. Environmental Protection Agency, Washington, DC.

USEPA (1999b). Understanding Variation in Partition Coefficient, $K_{d}$ values, Vol 2: Review of Geochemistry and Available $K_{d}$ Values for Cadmium, Cesium, Chromium, Lead, Plutonium, Radon, Strontium, Thorium, Tritium $\left({ }^{3} H\right)$, and Uranium. EPA 402-R-99-004B. U.S. Environmental Protection Agency, Washington, DC.

USEPA (1988). Limiting Values of Radionuclide Intake and Air Concentration and Dose Conversion Factors for Inhalation, Submersion, and Ingestion. EPA-520/1-88-020;

Environmental Protection Agency, Washington, DC, United States Government Printing Office; Federal Guidance Report 11.

USNRC (1974). Applications of Bioassay for Uranium. Regulatory Guide 8.11. U.S. Nuclear Regulatory Commission, Washington, DC. 
USNRC (1988). Bioassay at Uranium Mills. Regulatory Guide 8.22. U.S. Nuclear Regulatory Commission, Washington, DC.

USNRC (1991). Standards for Protection Against Radiation. Nuclear Regulatory Commission, Washington, DC: United States Government Printing Office; Title 10, Code of Federal Regulations, Part 20, Appendix B.

U.S. National Research Council (2008). Review of Toxicologic and Radiologic Risks to Military Personnel from Exposure to Depleted Uranium During and After Combat. The National Academies Press, Washington, DC.

Voegtlin, C.; Hodge, H. C., eds. (1953). Pharmacology and Toxicology of Uranium Compounds, National Nuclear Energy Series, Division VI - Volume I, Parts III and IV. McGraw-Hill, New York.

West, C. M.; Scott, L.; Schultz, N. B. (1979). "Sixteen years of uranium personnel monitoring experience. In retrospect." Health Phys. 36:665-669.

WHO (2001). Depleted Uranium. Sources, Exposure and Health Effects. Department of Protection of the Human Environment, WHO/SDE/PHE/01.1. World Health Organization, Geneva.

Wrenn, M. E.; Durbin, P. W.; Howard, B.; Lipsztein, J.; Rundo, J.; Still, E. T.; Willis, D. L. (1985). "Metabolism of ingested U and Ra." Health Phys. 48:601-633. 



\section{APPENDIX A: BASIC COMPONENTS OF A URANIUM BIOASSAY PROGRAM}

\section{A.1. Common Methods of Monitoring for Uranium}

A uranium monitoring program should include bioassay measurements for individual workers as well as direct monitoring of workplace conditions. A bioassay measurement is defined as an analysis of radioactive material in biological material excreted or otherwise removed from the body (in vitro measurement) or in body organs or the whole body by external measurement (in vivo measurement).

Continuous air monitoring during work hours generally is the primary method of monitoring uranium exposure in the workplace. An air monitoring program should include not only determination of the mass concentration and activity concentration of uranium in air but also measurement of the solubility of aerosols in which uranium is carried. The main purpose of the solubility measurements is to determine whether a substantial portion of airborne material is likely to be insoluble (i.e., dissolved at an extremely slow rate) in lung fluid and thus to present an increased radiation hazard due to long-term retention in the lungs.

Other methods of monitoring of the workplace include use of portable survey meters to measure alpha or beta activity on surfaces or gamma radiation in air, and detection of removable radionuclides on surfaces based on smear samples. These types of measurements are not easily converted to meaningful estimates of intake of uranium and are not addressed in this report.

Bioassay measurements provide checks on the effectiveness of direct monitoring of workplace conditions and allow derivation of radiation dose estimates and uranium concentrations in the kidneys when intakes of uranium are identified. Three main types of bioassay measurements are used in monitoring programs for uranium:

- measurement of uranium in urine;

- measurement of uranium in feces;

- in vivo measurements of uranium in the chest.

In addition, nostril swabs are used to check for possible inhalation of uranium following an accidental release. Nostril swabs are not reliable quantitative measures of inhaled uranium and are not addressed in this report.

Some investigators have evaluated hair and toenails as bioassay media for uranium (Karpas 2001; Karpas et al. 2005; Mohagheghi et al. 2005). As discussed in Appendix B, the value of hair or nail samples as measures of uranium intake is limited by the possible presence of significant external deposits of uranium that cannot be removed by washing the samples. 


\section{A.2. Frequency and Normalization of Bioassay Measurements}

Bioassay measurements are divided into four categories:

- baseline measurements;

- routine measurements during potential exposure to uranium;

- special measurements;

- termination measurements.

Baseline bioassay measurements are made prior to initial work activities involving uranium.

Routine bioassay measurements are made at regular intervals during the period of work with uranium to confirm that appropriate controls exist and to assess radiation dose and the concentration of uranium in the kidneys associated with routine intake of uranium.

Special bioassay measurements may be made if an abnormally high intake of uranium is known or suspected. Circumstances indicating the need for special measurements include:

- presence of unusually high levels of radionuclides in nasal passages;

- entry into contaminated areas without appropriate exposure controls;

- operational events with a reasonable likelihood that a worker was exposed to unknown quantities of airborne radioactive material (e.g., loss of container integrity);

- incidents that result in entry of radionuclides through wounds;

- an unfavorable trend in routine measurements.

A termination bioassay measurement is made when a worker is no longer subject to the uranium bioassay program because of termination of employment or change in work location.

Urinary uranium is the most common type of bioassay measurement made for uranium workers. Action levels for urinary uranium generally are given in terms of 24-h urinary excretion of uranium. In practice, the rate of excretion of uranium in urine often is based on a spot sample rather than 24-h collection of urine. Due to diurnal variation in the rate of urinary excretion of uranium, the mass or activity of uranium in a spot sample should be normalized to a 24-h excretion rate on the basis of the creatinine content of the sample (Jackson, 1966; Karpas et al. 1998; Marco et al. 2008). Reference values for 24 -h creatinine excretion are $1.7 \mathrm{~g} / \mathrm{d}$ for an adult male and $1.0 \mathrm{~g} / \mathrm{d}$ for an adult female (ICRP 2002). If the creatinine content of a spot urine sample has not been determined, 24-h urinary uranium should be estimated by normalizing the excreted volume of urine to the reference $24-\mathrm{h}$ volume of $1.6 \mathrm{~L}$ for adult males and $1.2 \mathrm{~L}$ for adult females (ICRP 2002). Although the action levels given in this report are based on characteristics of a reference adult male, estimates of 24-h urinary uranium based on spot samples should be based on gender-specific 24 -h values for urine volume and creatinine excretion.

Determination of the frequency of routine urine measurements depends mainly on the exposure potential of the individual. At least quarterly sampling is recommended for workers who are frequently near uranium sources. Weekly urine sampling is recommended for workers such as uranium miners or millers who routinely work in areas with elevated concentrations of airborne uranium. 
When an elevated intake of uranium is known or suspected, special urinalyses should be used to estimate the level of intake and determine the rate of removal of uranium from the body. Special samples might be collected daily for a few days following an incident and at wider intervals after a pattern of change with time in urinary uranium starts to emerge. Special samples are ended when background concentrations of urinary uranium are approached. Measurements involving about 5000 individuals across the U.S. indicate that the concentration of uranium in urine in persons without occupational exposure typically is on the order of 9 ng per liter (geometric mean) and rarely above $50 \mathrm{ng}$ per liter (NHANES 2005).

Fecal bioassay generally is not collected routinely but may be included in special bioassay programs as an aid in determining total intake and the possibility of accumulation of insoluble activity in the lungs. In case of inhalation of a relatively insoluble uranium aerosol, there may be little absorption of uranium to blood and hence little urinary excretion of uranium, but typically there is still clearance from the lungs to feces. A low urinary to fecal excretion ratio for uranium in a worker provides suggestive evidence that all or nearly all of the inhaled uranium is in relatively insoluble form.

In vivo thorax measurements should be made routinely on an annual or semi-annual basis, even if airborne uranium is thought to be in soluble form. Special in vivo thorax measurements should be used to estimate the level of intake in the event of known or suspected short-term exposure to relatively insoluble uranium. Exposure to relatively insoluble forms of uranium may not be revealed by urinalysis due to a low rate of dissolution of the inhaled material in the lungs and subsequent absorption of uranium to blood.

\section{A.3. Overview of Analytical Methods for Uranium Bioassay}

\section{A.3.1. In vitro Measurement of Uranium}

In general, methods of measurement of urinary uranium also apply to fecal uranium except that for fecal measurement the matrix requires extensive preparation. For example, for alpha spectroscopy the preparation of fecal samples includes ashing, cleaning by co-precipitation, and solvent extraction followed by electrodeposition and alpha spectroscopy (ATSDR 1999).

Bogard 1996 reviewed approximately 50 articles on measurements of uranium in excreta and tissues. The major methods identified include alpha spectrometry, liquid scintillation spectrometry, fluorometry, phosphorometry, neutron activation analysis, fission-track counting, UV-visible absorption spectrophotometry, resonance ionization mass spectrometry, and inductively-coupled plasma mass spectrometry (ICP-MS). Table A.1 provides an overview of the analytical methods identified (Bogard 1996).

Articles published in the last few years describe new approaches for sample analysis such as laser ablation ICP-MS and chromatography-inductively coupled plasma mass spectrometry. Also, there has been improved effectiveness and reduced cost of some older methods.

A recent review by Todorov et al. 2007 on analytical methods for detection of uranium in tissues and biological fluids contains a comparative summary of methods including sample preparation 
and cost (Table A.2). The review by Todorov and coworkers was concerned with measurement of depleted uranium, but the same methods are applicable to natural or enriched uranium.

Table A.1 Uranium detection levels for different analytical methods (Bogard 1996)

\begin{tabular}{|c|c|c|c|}
\hline Method & $\begin{array}{c}\text { Measurement } \\
\text { level } \\
(\mathrm{ng} / \mathrm{L}) \\
\end{array}$ & $\begin{array}{l}\text { Detection } \\
\text { limit } \\
(\text { ng/L) } \\
\end{array}$ & Description \\
\hline $\begin{array}{l}\text { UV-visible } \\
\text { spectrophotometry }\end{array}$ & $5,000-66,000$ & $\mathrm{NA}^{\mathrm{a}}$ & $\begin{array}{l}\text { Uranium determined from } \\
\text { absorbance of uranyl-arsenazo III at } \\
653 \mathrm{~nm}\end{array}$ \\
\hline $\begin{array}{l}\text { UV-visible } \\
\text { spectrophotometry } \\
\text { (variation) }\end{array}$ & NA & 290 & $\begin{array}{l}\text { Measurement of difference in } \\
\text { absorbance at } 665 \text { and } 800 \mathrm{~nm} \text { using } \\
\text { dual-beam spectrophotometer. }\end{array}$ \\
\hline $\begin{array}{l}\text { Fluorometry }(\mathrm{NaF} \text { and } \\
\mathrm{NaF} / \mathrm{LiF})\end{array}$ & $100 \pm 100$ & NA & Based on ASTM standard (1983) \\
\hline UV laser fluorometry & $1000-7000$ & NA & $\begin{array}{l}\text { Use of laser provides frequency } \\
\text { control for used interference }\end{array}$ \\
\hline UV laser fluorometry & 0.01 & NA & $\begin{array}{l}\text { Co-precipitating uranium from } \\
\text { aqueous solution with } \mathrm{CaF}_{2}\end{array}$ \\
\hline Kinetic phosphorescence & $15-30$ & 10 & $\begin{array}{l}\text { Estimates uranyl ion concentration by } \\
\text { phosphorescence intensity after } \\
\text { pulsed laser excitation }\end{array}$ \\
\hline $\begin{array}{l}\text { Alpha particle energy } \\
\text { spectrometry }\end{array}$ & NA & $\begin{array}{c}7 \mathrm{E}-07 \\
1 \mathrm{E}-03 \\
2 \mathrm{E}-03 \\
8.0 \\
40\end{array}$ & $\begin{array}{l}\mathrm{U}-232 \\
\mathrm{U}-233 \\
\mathrm{U}-234 \\
\mathrm{U}-235 \\
\mathrm{U}-238\end{array}$ \\
\hline $\begin{array}{l}\text { Neutron activation } \\
\text { analysis }\end{array}$ & $1-5000$ & NA & $\mathrm{U}-238$ \\
\hline Fission-track analysis & $100-700$ & 10 & $\mathrm{U}-235$ \\
\hline Delayed neutron analysis & 500 & NA & $\mathrm{U}-235$ \\
\hline $\begin{array}{l}\text { Resonance ionization mass } \\
\text { spectroscopy }\end{array}$ & 1000 & 50 & \\
\hline $\begin{array}{l}\text { Inductively coupled } \\
\text { plasma-mass spectrometry }\end{array}$ & $\begin{array}{c}74-372 \\
2000-8000\end{array}$ & NA & $\begin{array}{l}\mathrm{U}-235 \\
\mathrm{U}-238\end{array}$ \\
\hline
\end{tabular}

${ }^{a} \mathrm{NA}=$ not available. 
Table A.2 Instrument analysis techniques used for uranium in biological samples (Todorov 2007)

\begin{tabular}{|c|c|c|c|c|c|}
\hline Method & $\begin{array}{c}\text { Total U } \\
\text { detection } \\
\text { limit } \\
(\text { ng/L) }\end{array}$ & $\begin{array}{l}\text { Type of } \\
\text { analysis } \\
\text { possible }\end{array}$ & Precision $^{a}$ & $\begin{array}{c}\text { Sample } \\
\text { throughput }\end{array}$ & Cost \\
\hline $\begin{array}{l}\text { Kinetic } \\
\text { phosphorescence } \\
\text { analysis }\end{array}$ & 10 & Total U & $5 \%$ & High & Low \\
\hline Alpha spectrometry & 40 & $\begin{array}{l}\text { Total and } \\
\text { isotopic U }\end{array}$ & $10 \%$ & Low & Moderate \\
\hline $\begin{array}{l}\text { Thermal ionization } \\
\text { mass spectrometry }\end{array}$ & $<1$ & $\begin{array}{l}\text { Total and } \\
\text { isotopic U }\end{array}$ & $0.02 \%$ & Low & High \\
\hline $\begin{array}{l}\text { Instrumental neutron } \\
\text { activation analysis }\end{array}$ & 10 & $\begin{array}{l}\text { Total and } \\
\text { isotopic U }\end{array}$ & $10 \%$ & Low & High \\
\hline $\begin{array}{l}\text { Delayed neutron } \\
\text { counting }\end{array}$ & 10 & $\begin{array}{l}\text { Total and } \\
\text { isotopic U }\end{array}$ & $10 \%$ & Moderate & High \\
\hline $\begin{array}{l}\text { Inductively coupled } \\
\text { plasma-mass } \\
\text { spectrometry }\end{array}$ & $<1$ & $\begin{array}{l}\text { Total and } \\
\text { isotopic U }\end{array}$ & $0.1-5 \%$ & High & Moderate \\
\hline
\end{tabular}

Use of ICP-MS for analysis of uranium in bioassay samples has increased considerably in recent years (Becker 2005). Advantages of this method compared with other common techniques such as alpha spectrometry include some or all of the following: high sensitivity, low cost, ease of sample preparation, and short analysis time (Karpas et al 1996; Maxell and Fauth 2002; Hang et al. 2004; Bouvier-Capely et al. 2004; Becker 2005). Table A.3 compares limits of detections of variations of ICP-MS. 
Table A.3 Limits of detection of variations of the ICP-MS method of measuring uranium in urine

\begin{tabular}{lllc}
\hline \multicolumn{1}{c}{ Reference } & \multicolumn{1}{c}{$\begin{array}{c}\text { Sample } \\
\text { Preparation }\end{array}$} & Instrument & $\begin{array}{c}\text { Limit of } \\
\text { detection }^{\prime} \\
\text { (ng/L) }\end{array}$ \\
\hline Becker 2004 & Laser ablation & SF-ICP-MS & 0.1 \\
Karpas et al. 1996 & Nitric acid dilution & Q- ICP-MS & 3.0 \\
Hang et al. 2004 & Online extraction & Q-ICP-MS & 2.0 \\
Schaumlöffel et al. 2005 & $\begin{array}{l}\text { Digestion, } \\
\text { preconcentration }\end{array}$ & SF-ICP-MS & 1.6 \\
Becker, et al. 2002 & Digestion & SF-ICP-MS & 0.1 \\
Mohagheghi et al. 2005 & Direct dilution & Q-ICP-MS & 15 \\
Parrish 2006 & Digestion, extraction & MC-ICP- & $<1$ \\
& & MS & \\
Krystek et al. 2008 & Direct dilution & HR-ICP-MS & 0.2 \\
\hline${ }^{a}$ SF = sector field, Q = quadrupole, MC = multi-collector, HR = high resolution.
\end{tabular}

\section{A.3.2. In vivo Measurement of Uranium}

External measurements over the chest are used to detect accumulation of uranium in the lungs. The preferred detector for uranium in vivo counting is a germanium detector (WHO 2001), but sodium iodide and phoswich detectors have also been used (ATSDR 1999).

The ${ }^{235} \mathrm{U}$ activity in the lungs is estimated from measurement of photon emissions from ${ }^{235} \mathrm{U}$ $(186 \mathrm{keV})$. In some measurement systems the ${ }^{238} \mathrm{U}$ activity is also estimated by measurement of photon emissions from its daughter ${ }^{234} \mathrm{Th}(63 \mathrm{keV}$ and $93 \mathrm{keV})$, assuming that ${ }^{234} \mathrm{Th}$ is in equilibrium with ${ }^{238} \mathrm{U}$.

In vivo counting systems generally are calibrated using phantoms made of polystyrene or other tissue equivalent material and having shapes similar to the human torso. Uranium sources with known activity are inserted into the phantom at locations where uranium would be expected to accumulate in a human body, and relationships are determined between the known and detected activity (DOE 1988).

The accuracy of chest measurements of uranium is limited by:

- the weak photon energies, particularly for ${ }^{234} \mathrm{Th}$; 
- the low yield of photon emissions;

- uncertainty in the calibration associated with uncertainties and individual differences in chest wall thickness and location of internally deposited uranium in the chest;

- uncertainty in the assumption of equilibrium of ${ }^{234} \mathrm{Th}$ and ${ }^{238} \mathrm{U}$.

Additionally, the level of ${ }^{234} \mathrm{U}$ in the lungs is not revealed by external measurements and must be estimated on the basis of an assumed isotopic composition of inhaled uranium. The isotopic composition of inhaled uranium is reasonably well known in some cases from information on the form of uranium being handled and also can be estimated from the relative concentrations of uranium isotopes in urine of the exposed worker.

The minimum detectable activity (MDA) of total uranium in the chest depends on the type of detector used, the counting time, and the isotopic composition of uranium in the chest. The MDA for a counting time of 45-60 min using a germanium detector is on the order of $4 \mathrm{~Bq}$ of ${ }^{235} \mathrm{U}$ and $100 \mathrm{~Bq}$ of ${ }^{238} \mathrm{U}$ (WHO 2001; Kramer et al. 2003). The MDA for total activity in the chest depends on the percentage of total activity represented by ${ }^{235} \mathrm{U}$ and ${ }^{238} \mathrm{U}$ and hence on the isotopic composition of inhaled uranium.

\section{A.4. Examples of Ongoing Uranium Bioassay Programs}

\section{A.4.1. Oak Ridge National Laboratory}

Oak Ridge National Laboratory (ORNL) is a Department of Energy (DOE) operation. DOE requirements for occupational radiation protection are given in Title 10 of the Code of Federal Regulations, Part 835 (10CFR835). These requirements include specific dose limits but are also subject to the ALARA (As Low As Reasonably Achievable) principle. Dose limits specified in 10CFR835 are in terms of the committed effective dose equivalent (CEDE) as defined in ICRP Publication 26 (1977). In the following description of the ORNL program, "dose" refers to CEDE.

10CFR835 requires an employee to participate in a bioassay program if intakes of uranium or other radionuclides in any 1-y period are likely to result in a dose exceeding $0.001 \mathrm{~Sv}$. At a minimum, bioassay programs must be able to demonstrate compliance with a dose limit of $0.05 \mathrm{~Sv}$, but the goal is to keep doses below $0.001 \mathrm{~Sv}$.

The bioassay program at ORNL addresses potential exposure to a number of different radionuclides including uranium (McLaughlin 2005). The program bases monitoring requirements on exposure trends and measured internal doses. Data from 1992 through 2004 indicate that $\sim 15 \%$ of employees participate in the monitoring program, $>95 \%$ of monitored workers have no detectable intakes, $>90 \%$ of detected intakes resulted in an estimated dose less than $0.001 \mathrm{~Sv}$, and all intakes resulting in doses of $0.001 \mathrm{~Sv}$ or greater arose from abnormal events. From the evaluation of historical records it was determined that:

- routine bioassay monitoring has detected intakes that were not identified by other indicators;

- internal doses exceeding 0.001 Sv are unusual;

- the potential for exceeding regulatory dose limits exists at ORNL. 
Participation in the routine monitoring program generally is based on an individual's radiological work history and present type of work, but any employee may choose to participate in the program. Participants who have not performed radiological work for one year are considered for removal from the program. The minimum monitoring frequency is an annual urinalysis and in vivo lung count. More frequent monitoring is required in many workers on the basis of the type of work performed, potential for exposure, and the individual's work history.

Special monitoring is implemented only after an unplanned, uncontrolled radiation release that could result in a dose $>0.001 \mathrm{~Sv}$. Following an incident, the need for special bioassay sampling is determined on a situation specific basis by the Internal Dosimetrist and Surveillance Section personnel. If the Internal Dosimetrist is unavailable, special monitoring can be initiated by any of a number of possible findings such as a positive nostril swab, detection of radionuclides inside a worker's respiratory equipment, exposure to a specified level of uranium in air, identification of specified levels of external alpha or beta-gamma activity on certain areas of the body, and identification of specified levels of removable alpha or beta-gamma activity in and around work areas.

Action levels that have been established to ensure that follow-up monitoring is taken as appropriate are listed in Table A.4.

Table A.4 ORNL administrative control action levels for an accidental exposure

\begin{tabular}{ll}
\hline$>0.005 \mathrm{~Sv}$ & - Collect and analyze at least three consecutive 24-h urine \\
& samples. Collect and analyze 24-h urine sample \\
approximately one week after intake. Continue to sample & on regular basis. Fecal sampling should be considered. \\
- Perform whole body (or appropriate organ) count every two & to three days following intake. \\
- Review air sample data. & - Perform bioassay of others in area if appropriate. \\
& - Check external dose for the year and limit exposure as \\
& necessary. \\
& - Perform several appropriate bioassay measurements during \\
& the 2-3 weeks following exposure. \\
- & Measurements should be distributed throughout time period. \\
- & Discontinue measurement method when results are below \\
& detection for 2 consecutive sampling periods. \\
& - Use estimated dose equivalent as recorded value. \\
& - Confirmatory measurement may be performed 2-3 days \\
& after exposure.
\end{tabular}


Urine sampling is the preferred method of in vitro measurement. Twenty-four hour urine samples are suggested for the routine program and are mandatory in most cases for unusual events. NCRP Report No. 87, "Use of Bioassay Procedures for Assessment of Internal Radionuclide Deposition," (NRCP 1987) is referred to for details.

For special bioassay requirements it is suggested that fecal samples be collected for several days immediately after the event.

The following methods are employed in the analysis of in vitro samples: alpha spectrometry, liquid scintillation, and gamma spectroscopy.

In vivo lung measurement is performed with a three-detector array of germanium detectors placed in contact with the chest. The baseline count time is $30 \mathrm{~min}$, but adjustments are made on the basis of estimated chest wall thickness.

\section{A.4.2. U.S. Army Center for Health Promotion and Preventive Medicine}

Depleted uranium (DU) is used by the U.S. military in armor-piercing munitions and tank armor. Largely as a result of lessons learned from the 1991 Gulf War, a DU bioassay program was instituted for subsequently deployed U.S. military personnel who have the potential for exposure to DU through embedded DU fragments, inhalation, ingestion, and contamination of wounds.

The U.S. Army Center for Health Promotion and Preventive Medicine (USACHPPM) has developed a uranium bioassay program for U.S. Army personnel potentially exposed to DU. The goal is to identify personnel with elevated exposures to DU and refer them to a follow-up and medical surveillance program conducted by the U.S. Department of Veterans Affairs (Szrom and Alberth 2007).

The U.S. Army program requires that redeployed personnel fill out a post-deployment health assessment questionnaire, which is reviewed by medical personnel. If a potential exposure to DU is indicated, a DU-specific questionnaire is completed and reviewed by medical personnel, who assign one of three potential exposure categories:

- Category I - soldiers in, on, or near an armored vehicle struck and penetrated with DU munitions;

- Category II - soldiers entering DU-damaged vehicles;

- Category III - soldiers with incidental DU exposure.

Soldiers assigned to Category I or II must submit a urine specimen (24-h samples preferred) for uranium and isotopic ratios analyses (Assistant Secretary of Defense 2003 and U.S. Army Medical Command 2007). Participation is voluntary for soldiers assigned to Category III.

Inductively coupled plasma - mass spectrometry (ICP-MS) is used to determine the ${ }^{238} \mathrm{U}$ mass concentration and ${ }^{235} \mathrm{U} /{ }^{238} \mathrm{U}$ ratio measurement in urine samples. Detection limits are $\sim 1 \mathrm{ng} / \mathrm{L}$ or $\sim 0.00001 \mathrm{~Bq} / \mathrm{L}$ for ${ }^{238} \mathrm{U}$ concentration and $\sim 5 \mathrm{ng}{ }^{238} \mathrm{U} / \mathrm{L}$ for ${ }^{235} \mathrm{U} /{ }^{238} \mathrm{U}$ ratio measurements.

Interpretation of urinary uranium measurements is based on current ICRP models, e.g., the respiratory model shown in Figure 3.1 and the systemic model shown in Figure 3.8. Exposure 
dates are estimated from the DU questionnaires. The ICRP models are used to calculate screening levels for urinary uranium based on the assumed exposure time and mode of exposure. The screening level for a given case is indicative of an effective dose below $0.005 \mathrm{~Sv}$ and a kidney concentration below $3 \mu \mathrm{g}$ DU / g kidney.

Urinary uranium levels less than $25 \mathrm{ng} \mathrm{U} / \mathrm{L}$ and less than the screening level for the specific exposure case are considered as negative results. If the uranium concentration is greater than $25 \mathrm{ng} \mathrm{U} / \mathrm{L}$, an isotopic ratio analysis is performed in an effort to determine whether the excreted uranium is largely DU. If the isotopic ratios are indicative of DU, the radiation dose and renal concentration attributable to DU are estimated. The USACHPPM sends the results of the analyses, including comparison with background urinary uranium concentrations (CDC 2005) and interpretations, to the soldier's health care provider who is responsible for communicating the results to the soldier. The USACHPPM also provides archive copies of the results and interpretations to the U.S. Army Dosimetry Center and the Department of Defense Deployment Health Clinical Center (Szrom and Alberth 2007). 


\section{APPENDIX B: FEASIBILITY OF USING HAIR AND NAILS AS BIOASSAY MEDIA FOR URANIUM}

\section{B.1. Studies of Uranium Levels in Hair and Nails}

A number of investigators have proposed the use of hair or toenails as biomarkers for intake of uranium (Byrne and Benedik 1991; Karpas et al. 1996, 2005a, 2005b; Gonnen et al. 2000; Karpas 2001; Ough et al. 2002; Akamine et al. 2007). A review of the literature was performed to assess the potential usefulness and practicality of these biomarkers in a uranium bioassay program.

The following paragraphs summarize the key findings of this review. The main conclusion is that uranium measured in hair and nails cannot be assumed to arise wholly, or even mainly, from internally deposited uranium.

Most of the studies of uranium in hair and nails have been aimed at determining baseline concentrations of uranium in environmentally exposed persons. A wide range of uranium concentrations have been found. For example, Gonnen et al. 2002 found a mean concentration in hair of $62 \mathrm{ng} \mathrm{U} / \mathrm{g}$ and a range of 10-180 $\mathrm{ng} \mathrm{U} / \mathrm{g}$ in an Israeli population, and Akamine et al. 2007 determined a mean of $15.4 \mathrm{ng} \mathrm{U} / \mathrm{g}$ and a range of 2.1-49.8 $\mathrm{ng} \mathrm{U} / \mathrm{g}$ in a Brazilian population.

Karpas et al. 2005a, 2005b estimated the relative quantities of absorbed uranium excreted in urine, hair, and nails. They measured the concentration of uranium in urine, hair, and nails due to continuous exposure through ingestion of drinking water. The study population consisted of 205 individuals living in 134 different households in southern Finland where drinking water is supplied from private wells. The population was selected to include a wide range of daily intake of uranium in drinking water. Hair and toenail samples were rinsed to remove external uranium prior to acid digestion and analysis. The authors found that the uranium content in all excretion pathways was correlated with the uranium intake. The amount of uranium removed per unit time through each pathway was calculated using urinary volume, hair, and nail growth values for Reference Man. The amounts of uranium excreted through urine and hair were estimated to be roughly equivalent, and excretion through nails was estimated as $<1 \%$ of total excretion.

Karpas et al. 2005b state that "The most significant conclusion from both types of analysis is that the amount of uranium removed through hair growth is equivalent to removal through urine, as has been pointed out previously (Karpas 2001). This clearly indicates that the omission of this factor in the current biokinetic models [for uranium] is a shortcoming of these models."

A high level of excretion of internally deposited uranium in hair as claimed by Karpas and coworkers is inconsistent with extensive data on the fate of internally deposited uranium in laboratory animals and humans. The preponderance of uranium that reaches blood is excreted in urine within a few days after intake and in adults $>90 \%$ is excreted in urine within a few weeks. The balance is largely accounted for by bone and kidney deposits and fecal excretion. Very low uranium concentrations in skin and hair have been found at times from a few days to a few months after exposure (Struxness et al. 1956; Bentley et al. 1982). 
The discrepancy between the results of the biokinetic studies of administered uranium and the results of Karpas and coworkers is not clear, but it could be that the measured uranium in hair, at least, is largely exogenous in origin despite the efforts of the investigators to clean the hair samples. A review of the literature reveals the difficulty in distinguishing between internal and external sources of metals in hair.

\section{B.2. The Problem of Distinguishing Between Internal and External Sources}

Hair is composed of hard keratin and is chemically denser than other forms of keratin such as calluses and dander flakes. Where the hair shaft separates from the follicle it undergoes "disjunctive" keratizination, which involves the splitting of layers and exposing surfaces not previously exposed. Keratinized cells have tiny pores littering their surfaces. The cells are flattened and tightly bound to their neighbors in a very complex array that may begin to split apart by an unknown process, allowing external agents to be trapped in openings near the outer surface of the hair (ATSDR 2001). The binding of metals in hair is believed to involve sulfur, which is found in high concentration in hair, as well as carboxyl groups (Hinners et al. 1974). The common method for visualizing keratin groups in keratin fibers is with an aqueous solution of uranyl salts in which ionic binding of the uranyl ion occurs (Swift 1996).

It has been found that trace elements bind to human hair to different degrees. For example, copper is very firmly bound to hair and is difficult to remove by washing. In fact, measurements have revealed that copper migrates into the hair on washing. In contrast, such a treatment causes considerable loss of cadmium (Bencze 1994).

In samples taken at a lead-exposed workplace it was found that Turkish women had significantly lower levels of lead in hair than German women although the blood lead levels were the same. A closer investigation revealed that the Turkish women all worked in head scarves and the German women worked bareheaded. The concentration difference was still appreciable after the hair samples had been cleaned. The exogenous lead could not be removed completely (Bencze 1994).

The Agency for Toxic Substances and Disease Registry (ATSDR) convened a panel of experts in fields of hair analysis, toxicology, and medicine to review and discuss the current state of the science related to hair analysis, specifically its use in assessing environmental exposures (ATSDR 2001). The panelists agreed that using hair analysis as a diagnostic tool for exposure to metals is severely limited by difficulties in distinguishing between internal and external sources of metals. Arsenic was frequently used by panel members to illustrate pros and cons of hair and nails as biomarkers for internal exposure.

- In a study of arsenic levels in tap water, urine, hair, and nails, persons drinking bottled water but bathing in tap water with average arsenic concentration $345 \mu \mathrm{g} / \mathrm{L}$ had on average 12 times higher levels of arsenic in hair than persons drinking and bathing in tap water with arsenic containing $30 \mu \mathrm{g} / \mathrm{L}$. Arsenic levels in urine were similar in the two groups, indicating similar levels of absorbed arsenic in the groups. This example illustrates the difficulties in using hair concentrations alone to draw inferences regarding the magnitude of absorption of a metal to blood. 
- Various studies have examined the role or effectiveness of washing hair in order to distinguish between endogenous and exogenous sources of arsenic. These studies suggest that no truly good washing method exists to remove arsenic. If hair is not washed aggressively, exogenous arsenic will remain. If hair is washed too aggressively, endogenous arsenic may be removed. Concentrations of arsenic in hair will vary depending on washing method, with no method shown to be capable of removing all arsenic.

- Findings suggest that external activity is also an issue with nails. For example, a study that measured arsenic in nails over time following arsenic ingestion revealed the following: (1) elevated levels of arsenic were measured in distal segments of unscraped nails and believed to be deposited by sweat; (2) scraped nails during the same period did not reveal elevated levels; and (3) samples of scraped nails taken later in time showed elevated arsenic levels as a result of the ingestion episode.

- Examples were given to demonstrate valid uses of nails, at least, as a biomarker. A panelist summarized the results of a case study in which he was requested to evaluate an individual with peripheral neuropathy months after possible exposures to lead and arsenic. Total arsenic urinalysis had been performed closer to the time of exposure, but not a fractionated analysis. To evaluate past exposures, a toenail sample was taken down to the growth plate, which was negative. These results were used to conclude that the individual had not been exposed to arsenic within the past year.

\section{B.3. Example of a Toxin for Which Hair is a Workable Bioassay Medium}

The ATSDR hair analysis panelists generally agreed that despite considerable efforts to determine relationships between concentration of various chemical toxins in hair and adverse health effects from those toxins, relationships have been established for only one toxin: methylmercury. For example, a relation has been established between maternal hair levels of methylmercury and observed developmental neurological abnormalities in offspring.

Cernichiari et al. 1995, 2007 and Zareba 2008 discuss the advantages of maternal hair as bioassay medium for estimating prenatal exposure to methylmercury. Their conclusions are summarized below. Original references to the cited information can be found in Cernichiari et al. 2007.

Studies on laboratory animals indicate that methylmercury enters hair via the follicle and is only accumulated when the follicle is in the growing phase. These findings were confirmed in studies of human hair grafted onto mice. Autoradiographic observations in these studies demonstrated that radioactive methylmercury was taken up by the keratinocytes and eventually deposited in the high sulfur keratin proteins. Once incorporated into the hair strand, the mercury level remains stable. This suggests that the levels of mercury along the length of the hair strand should provide a historical record of the levels of the transportable methylmercury in plasma.

Hair levels of mercury closely follow whole blood levels in the same individual and over a wide range of concentrations in blood. The concentration ratio of hair to whole blood is expected to show variation from one individual to another due to genetic differences. The ratio of hair to whole blood levels appears to change with age, but this is not firmly established. 
The uptake of mercury into hair is apparently selective to methylmercury and does not occur with inorganic mercury. In several individuals who were highly exposed to inorganic mercury, hair levels were slightly elevated over background, but were one to two orders of magnitude lower than those that would be expected from the same blood levels of methylmercury. This is a useful attribute of hair as a measure of methylmercury in blood because some inorganic mercury may be present in the blood stream of fish eating populations. Some methylmercury is converted to inorganic mercury in the GI tract, whereupon some absorption back into the blood stream may occur. Methylmercury is slowly converted to inorganic mercury in various body tissues and this might also contribute to blood levels of inorganic mercury. Maternal amalgam tooth fillings also elevate levels of inorganic mercury in both maternal and cord blood.

Experimental data support the use of hair as a biological indicator of brain methylmercury levels. Little uptake of inorganic mercury took place into hair. Inorganic mercury is known to be poorly transported across the blood-brain barrier. In fact, blood levels of methylmercury that correspond to the observed levels of inorganic mercury would have been expected to result in severe brain damage. The fact that these subjects had no neurological signs or symptoms is consistent with findings on the disposition of radioactive inorganic mercury where no radioactivity was detected in the head region. Thus it appears that uptake into hair mimics uptake into brain for both organic and inorganic species of mercury.

In the context of epidemiological studies, the hair sample offers appreciable practical advantages in that the collection is non-invasive, transport and storage are simple, and no refrigeration is required. A single hair sample can show the history of methylmercury levels in blood over months or even years, depending on the length of the hair strands. Non-destructive physical methods such as X-ray fluorescent spectrometry can measure mercury in single strands of hair. The difference in mercury levels between each strand has been shown to be less than the analytical variance.

Cernichiari et al. 2007 conclude that the use of maternal hair as an index of fetal brain levels is well justified because it offers practical advantages and because it has a firm physiological basis. 


\section{APPENDIX C: OTHER RADIONUCLIDES FREQUENTLY ENCOUNTERED AT URANIUM FACILITIES}

\section{C.1. Purpose of This Appendix}

Radionuclides other than the natural uranium isotopes ${ }^{234} \mathrm{U},{ }^{235} \mathrm{U}$, and ${ }^{238} \mathrm{U}$ sometimes are present in relatively high quantities at a uranium facility. The most frequently encountered such radionuclides are members of the ${ }^{238} \mathrm{U}$ and ${ }^{235} \mathrm{U}$ chains, with ${ }^{238} \mathrm{U}$ progeny typically being much more abundant than ${ }^{235} \mathrm{U}$ progeny. Health risks from exposure to ${ }^{238} \mathrm{U}$ progeny (excluding ${ }^{234} \mathrm{U}$ ) include lung cancer from inhalation of ${ }^{230} \mathrm{Th},{ }^{226} \mathrm{Ra}$, or short-lived progeny of ${ }^{222} \mathrm{Rn}$; risk of bone cancer from inhalation or ingestion of ${ }^{226} \mathrm{Ra}$; and risk of a number of different types of cancer from external exposure to photons emitted by different members of these chains.

Manmade radionuclides may be present at trace levels at some types of uranium facilities. For example, if the facility handles uranium feed material recycled from spent reactor fuel, the material may contain transuranics (e.g., ${ }^{237} \mathrm{~Np}$ and ${ }^{238-241} \mathrm{Pu}$ ), fission products (e.g., ${ }^{99} \mathrm{Tc}$ ), and uranium isotopes not found in nature (e.g., ${ }^{236} \mathrm{U}$ ) (Rich et al. 1988).

This appendix illustrates situations in which elevated levels of various members of the ${ }^{238} \mathrm{U}$ and

${ }^{235} \mathrm{U}$ chains may be encountered at uranium facilities and tabulates summary information on members of the two chains. Effective dose coefficients and biokinetic model predictions needed for interpretation of bioassay are tabulated for the following potentially significant types of internal exposure at uranium facilities: acute inhalation of soluble or moderately soluble forms of ${ }^{226} \mathrm{Ra}$; acute inhalation of moderately soluble or relatively insoluble forms of ${ }^{230} \mathrm{Th}$; and chronic inhalation of short-lived ${ }^{222} \mathrm{Rn}$ progeny. It is beyond the scope of this report to provide biokinetic and dosimetric predictions for a comprehensive set of radionuclides and exposure situations encountered at uranium facilities.

\section{C.2. Examples}

Uranium in raw ores is composed of approximately $99.27 \%{ }^{238} \mathrm{U}, 0.72 \%{ }^{235} \mathrm{U}$, and $0.0057 \%{ }^{234} \mathrm{U}$ by mass. Uranium-234 is part of the ${ }^{238} U$ chain, and ${ }^{235} U$ heads a separate chain. The ${ }^{238} U$ chain typically represents about $98 \%$ of the total activity of these two chains in uranium ore.

The ${ }^{238} \mathrm{U}$ and ${ }^{235} \mathrm{U}$ chains (excluding members with trivial yield) and their summary decay data are listed in Tables C.1 and C.2, respectively. Unprocessed uranium ore contains all of the radionuclides listed in Tables C.1 and C.2, with chain members nearly in equilibrium with the parent radionuclides ${ }^{238} \mathrm{U}$ and ${ }^{235} \mathrm{U}$ except for any reduction in activity in the lower portion of the ${ }^{238} \mathrm{U}$ chain due to escape of ${ }^{222} \mathrm{Rn}$ into air.

The kerma constants given in the last columns of Tables C. 1 and C.2 indicate the relative hazards of the chain members as sources of external exposure per unit activity present. Bismuth-214 in the ${ }^{238} \mathrm{U}$ chain has a high yield of energetic photons and can be a particularly important source of external exposure at uranium facilities where its long-lived predecessor ${ }^{226} \mathrm{Ra}$ is present in high quantity. 
Table C.1 The ${ }^{238} \mathrm{U}$ chain and decay data (Endo et al. 2005)

\begin{tabular}{|c|c|c|c|c|c|c|c|c|c|c|}
\hline \multirow{3}{*}{ Nuclide } & \multirow{3}{*}{ Half-life } & \multirow{3}{*}{$\begin{array}{l}\text { Decay } \\
\text { mode }^{a}\end{array}$} & \multicolumn{8}{|c|}{ Energy (MeV / nuclear transformation) } \\
\hline & & & \multirow{2}{*}{$\begin{array}{l}\text { Total } \\
\text { alpha }\end{array}$} & \multicolumn{2}{|c|}{$\begin{array}{l}\text { Prominent } \\
\text { alpha }\end{array}$} & \multirow{2}{*}{$\begin{array}{c}\text { Total } \\
\text { photon }\end{array}$} & \multicolumn{2}{|c|}{$\begin{array}{c}\begin{array}{c}\text { Prominent } \\
\text { photon }\end{array} \\
\end{array}$} & \multirow{2}{*}{$\begin{array}{c}\text { Total } \\
\text { electron }\end{array}$} & \multirow{2}{*}{$\begin{array}{c}\text { Kerma } \\
\text { constan } \\
\left(\mathbf{G y}-\mathbf{m}^{2} /\right. \\
\text { Bq-s) }\end{array}$} \\
\hline & & & & $\begin{array}{c}\text { Yield } \\
(\%)\end{array}$ & Energy & & $\begin{array}{c}\text { Yield } \\
(\%)\end{array}$ & Energy & & \\
\hline U-238 & $4.47 \mathrm{E}+9 \mathrm{y}$ & $\alpha, \mathrm{SF}$ & 4.19 & 79 & 4.20 & $<0.01$ & 3.04 & 0.016 & 0.009 & $2.0 \mathrm{E}-18$ \\
\hline Th-234 & $24.1 \mathrm{~d}$ & $\beta-$ & - & - & - & 0.011 & 4.84 & 0.063 & 0.062 & $2.8 \mathrm{E}-18$ \\
\hline $\mathrm{Pa}-234 \mathrm{~m}$ & 1.17 m & $\beta-$, IT & - & - & - & 0.016 & 0.84 & 1.001 & 0.817 & 7.3E-19 \\
\hline U-234 & $2.46 \mathrm{E}+5 \mathrm{y}$ & $\alpha$ & 4.76 & 71.4 & 4.78 & $<0.01$ & 4.18 & 0.016 & 0.014 & 2.7E-18 \\
\hline Th-230 & $7.54 \mathrm{E}+4 \mathrm{y}$ & $\alpha$ & 4.67 & 76.4 & 4.69 & $<0.01$ & 3.32 & 0.015 & 0.015 & $2.4 \mathrm{E}-18$ \\
\hline Ra-226 & $1600 \mathrm{y}$ & $\alpha$ & 4.77 & 94.4 & 4.78 & $<0.01$ & 3.59 & 0.186 & 0.004 & $5.1 \mathrm{E}-19$ \\
\hline Rn-222 & $3.82 \mathrm{~d}$ & $\alpha$ & 5.49 & 99.9 & 5.49 & $<0.01$ & 0.08 & 0.51 & $<0.001$ & $1.5 \mathrm{E}-20$ \\
\hline Po-218 & $3.1 \mathrm{~m}$ & $\alpha, \beta-$ & 6.00 & 100 & 6.00 & - & - & - & $<0.001$ & - \\
\hline $\mathrm{Pb}-214$ & $26.8 \mathrm{~m}$ & $\beta-$ & - & - & - & 0.253 & 37.6 & 0.352 & 0.295 & $1.5 \mathrm{E}-17$ \\
\hline $\mathrm{Bi}-214$ & $19.9 \mathrm{~m}$ & $\beta-, \alpha$ & $<0.1$ & 0 & 5.45 & 1.48 & 46.1 & 0.609 & 0.663 & $5.0 \mathrm{E}-17$ \\
\hline Po-214 & $1.6 \mathrm{E}-4 \mathrm{~s}$ & $\alpha$ & 7.69 & 100 & 7.69 & $<0.01$ & 0.01 & 0.8 & $<0.001$ & $3.1 \mathrm{E}-21$ \\
\hline $\mathrm{Pb}-210$ & $22.2 \mathrm{y}$ & $\beta-, \alpha$ & $<0.1$ & $<0.01$ & 3.72 & $<0.01$ & 10.11 & 0.011 & 0.04 & $9.4 \mathrm{E}-18$ \\
\hline Bi-210 & $5.01 \mathrm{~d}$ & $\beta-, \alpha$ & $<0.1$ & $<0.01$ & 4.64 & $<0.01$ & $<0.01$ & 0.304 & 0.389 & $1.5 \mathrm{E}-23$ \\
\hline Po-210 & $138.4 \mathrm{~d}$ & $\mathrm{~A}$ & 5.30 & 100 & 5.30 & $<0.01$ & $<0.01$ & 0.803 & $<0.001$ & $3.6 \mathrm{E}-22$ \\
\hline
\end{tabular}

${ }^{a} \mathrm{SF}=$ spontaneous fission, $\mathrm{IT}=$ isomeric transition

Table C.2 The ${ }^{235} \mathrm{U}$ chain and decay data (Endo et al. 2005)

\begin{tabular}{|c|c|c|c|c|c|c|c|c|c|c|}
\hline \multirow{3}{*}{ Nuclide } & \multirow{3}{*}{ Half-life } & \multirow{3}{*}{$\begin{array}{l}\text { Decay } \\
\text { mode }^{a}\end{array}$} & \multicolumn{8}{|c|}{ Energy (MeV / nuclear transformation) } \\
\hline & & & \multirow{2}{*}{$\begin{array}{l}\text { Total } \\
\text { alpha }\end{array}$} & \multicolumn{2}{|c|}{$\begin{array}{c}\text { Prominent } \\
\text { alpha }\end{array}$} & \multirow{2}{*}{$\begin{array}{l}\text { Total } \\
\text { photon }\end{array}$} & \multicolumn{2}{|c|}{$\begin{array}{c}\text { Prominent } \\
\text { photon }\end{array}$} & \multirow{2}{*}{$\begin{array}{c}\text { Total } \\
\text { electron }\end{array}$} & \multirow{2}{*}{$\begin{array}{c}\text { Kerma } \\
\text { constant } \\
\left(\mathbf{G y}-\mathbf{m}^{2} /\right. \\
\text { Bq-s) }\end{array}$} \\
\hline & & & & $\begin{array}{c}\text { Yield } \\
(\%)\end{array}$ & Energy & & $\begin{array}{c}\text { Yield } \\
(\%)\end{array}$ & Energy & & \\
\hline U-235 & $7.04 \mathrm{E}+8 \mathrm{y}$ & $\alpha$ & 4.39 & 55.6 & 4.40 & 0.167 & 57.2 & 0.186 & 0.053 & $1.3 \mathrm{E}-17$ \\
\hline Th-231 & $25.5 \mathrm{~h}$ & $\beta-$ & - & - & - & 0.027 & 26.55 & 0.013 & 0.162 & $1.8 \mathrm{E}-17$ \\
\hline $\mathrm{Pa}-231$ & $3.28 \mathrm{E}+4 \mathrm{y}$ & $\alpha$ & 4.97 & 25.6 & 5.02 & 0.045 & 19.4 & 0.013 & 0.054 & 1.6E-17 \\
\hline Ac-227 & $21.8 \mathrm{y}$ & $\beta-, \alpha$ & 0.07 & 0.6 & 4.95 & $<0.01$ & 1.36 & 0.013 & 0.015 & $9.7 \mathrm{E}-19$ \\
\hline Th-227 & $18.7 \mathrm{~d}$ & $\alpha$ & 5.88 & 24.1 & 6.04 & 0.132 & 19.66 & 0.012 & 0.075 & $2.0 \mathrm{E}-17$ \\
\hline Fr-223 & $22.0 \mathrm{~m}$ & $\beta-, \alpha$ & $<0.1$ & $<0.01$ & 5.46 & 0.058 & 33.9 & 0.05 & 0.383 & $1.1 \mathrm{E}-17$ \\
\hline $\mathrm{Ra}-223$ & $11.4 \mathrm{~d}$ & $\alpha$ & 5.67 & 51.6 & 5.72 & 0.141 & 25.94 & 0.084 & 0.078 & $1.3 \mathrm{E}-17$ \\
\hline Rn-219 & $3.96 \mathrm{~s}$ & $\alpha$ & 6.75 & 79.4 & 6.82 & 0.059 & 10.8 & 0.271 & 0.007 & $2.5 \mathrm{E}-18$ \\
\hline Po-215 & $1.8 \mathrm{E}-3 \mathrm{~s}$ & $\alpha$ & 7.39 & 99.9 & 7.39 & $<0.01$ & 0.04 & 0.439 & $<0.001$ & $6.9 \mathrm{E}-21$ \\
\hline $\mathrm{Pb}-211$ & $36.1 \mathrm{~m}$ & $\beta-$ & - & - & - & 0.064 & 3.78 & 0.405 & 0.454 & 2.6E-18 \\
\hline Bi-211 & $2.14 \mathrm{~m}$ & $\alpha, \beta-$ & 6.55 & 83.5 & 6.62 & 0.047 & 12.88 & 0.351 & 0.01 & $2.2 \mathrm{E}-18$ \\
\hline Tl-207 & $4.77 \mathrm{~m}$ & $\beta-$ & - & - & - & $<0.01$ & 0.26 & 0.898 & 0.495 & $8.6 \mathrm{E}-20$ \\
\hline Po-211 & $0.516 \mathrm{~s}$ & $\alpha$ & 7.44 & 98.9 & 7.45 & $<0.01$ & 0.56 & 0.898 & $<0.001$ & $3.1 \mathrm{E}-19$ \\
\hline
\end{tabular}


After extraction of uranium from ores mined by conventional techniques (underground or strip mining), the mill tailings contain only a small percentage of the original uranium isotopes but nearly all of most other members of the ${ }^{238} \mathrm{U}$ and ${ }^{235} \mathrm{U}$ chains. Because the concentrations of ${ }^{230} \mathrm{Th}$ and ${ }^{226} \mathrm{Ra}$ have not been reduced and ${ }^{222} \mathrm{Rn}$ and its short-lived progeny are still being produced by decay of ${ }^{226} \mathrm{Ra}$, the tailings represent many of the same internal and external radiation hazards as the unprocessed uranium ore.

In situ leaching (ISL) has become a common method of extracting uranium from underground deposits of low grade ores that are not economically recoverable by conventional mining techniques (Brown 2008). ISL involves introduction of a solvent solution, called a lixiviant, through injection wells drilled into the underground ore body. Lixiviants used in U.S. operations often consist of water containing added oxygen and carbon dioxide or sodium bicarbonate, which mobilize the uranium by reversing the chemical conditions that led to uranium deposition. The pregnant leach solution is pumped to the surface, fed to a mill, and processed to extract the uranium. Most radionuclides in the ${ }^{238} \mathrm{U}$ and ${ }^{235} \mathrm{U}$ chains are not mobilized from the underground deposit to a significant extent by the lixiviant, but relatively large quantities of ${ }^{230} \mathrm{Th},{ }^{226} \mathrm{Ra}$, and ${ }^{222} \mathrm{Rn}$ may be brought to the surface. The concentrations of these radionuclides in the solution may be much different from that of ${ }^{238} \mathrm{U}$. Typically, mobilized ${ }^{226} \mathrm{Ra}$ is in the form of carbonates or sulfates and represents about $5-15 \%$ of the equilibrium ${ }^{226} \mathrm{Ra}$ in the host formation.

The radiation protection program requirements at an ISL facility are similar in many respects to requirements at conventional uranium mining and milling facilities. For example, the requirements at an ISL facility include a uranium bioassay program; monitoring of long-lived alpha emitters $\left({ }^{234} \mathrm{U},{ }^{235} \mathrm{U},{ }^{238} \mathrm{U},{ }^{230} \mathrm{Th}\right.$, and $\left.{ }^{226} \mathrm{Ra}\right)$ in air in process and packaging areas; monitoring for external exposure; monitoring for ${ }^{226} \mathrm{Ra}$ build-up in equipment; and monitoring of ${ }^{222} \mathrm{Rn}$ and its short-lived progeny. Monitoring of ${ }^{222} \mathrm{Rn}$ at ISL facilities is particularly important at the front end of the process where ${ }^{222} \mathrm{Rn}$ is most likely to emanate from solutions returning from underground (Brown, 2008).

Monitoring at ISL facilities indicates considerable disequilibrium between ${ }^{222} \mathrm{Rn}$ and its shortlived progeny in many cases. Situations have been observed in well-ventilated areas in which the concentration of ${ }^{222} \mathrm{Rn}$ in air is high but concentrations of ${ }^{222} \mathrm{Rn}$ progeny are low. In contrast, concentrations of ${ }^{222} \mathrm{Rn}$ progeny considerably higher than that of ${ }^{222} \mathrm{Rn}$ have been observed in poorly ventilated areas. Thus, monitoring at ISL facilities should include measurement of ${ }^{222} \mathrm{Rn}$ daughters as well as ${ }^{222} \mathrm{Rn}$ itself (Brown 2008).

\section{C.3. Biokinetic and Dosimetric Data for ${ }^{226} \mathrm{Ra}$}

Data on clearance of inhaled radium compounds from the respiratory tract in laboratory animals and human subjects generally indicate that the compounds are relatively soluble (Type F) or moderately soluble (Type M) in the lungs (ICRP 1995b). Estimated fractional absorption of radium from the gastrointestinal tract to blood typically has been in the range $0.1-0.2$ in studies involving human subjects (ICRP 1993a). The ICRP applies an absorption fraction of 0.2 to radium for the cases of ingestion or inhalation of soluble or moderately soluble forms by adults (ICRP 1993a). 
The systemic biokinetic model for radium currently recommended by the ICRP is described in ICRP Publication 67 (1993a). The model structure is similar to that for uranium (Figure 3.8), but some of the non-skeletal compartments in the uranium model are combined in the radium model. For example, red blood cells and blood plasma are combined to form a single blood compartment. Parameter values for radium are given in Table C.3.

Table C.3 Transfer coefficients in the biokinetic model for systemic radium (ICRP 1993a)

\begin{tabular}{lc}
\hline \multicolumn{1}{c}{ Path } & $\begin{array}{c}\text { Transfer coefficient } \\
\left(\mathbf{d}^{-1}\right)\end{array}$ \\
\hline Plasma to urinary bladder contents & $6.060 \times 10^{-1}$ \\
Plasma to upper large intestine contents & $2.179 \times 10^{1}$ \\
Plasma to trabecular bone surface & $9.720 \times 10^{0}$ \\
Plasma to cortical bone surface & $7.780 \times 10^{0}$ \\
Plasma to ST0 & $2.268 \times 10^{1}$ \\
Plasma to ST1 & $7.000 \times 10^{0}$ \\
Plasma to ST2 & $7.000 \times 10^{-2}$ \\
Plasma to Liver 1 & $3.500 \times 10^{-1}$ \\
Trabecular bone surface to plasma & $5.780 \times 10^{-1}$ \\
Trabecular bone surface to exchangeable volume & $1.160 \times 10^{-1}$ \\
Cortical bone surface to plasma & $5.780 \times 10^{-1}$ \\
Cortical bone surface to exchangeable volume & $1.160 \times 10^{-1}$ \\
ST0 to plasma & $7.560 \times 10^{0}$ \\
ST1 to plasma & $6.930 \times 10^{-1}$ \\
ST2 to plasma & $3.800 \times 10^{-4}$ \\
Liver to plasma & $1.390 \times 10^{-2}$ \\
Exchangeable trabecular bone volume to surface & $1.850 \times 10^{-2}$ \\
Exchangeable to nonexchangeable trabecular bone volume & $4.600 \times 10^{-3}$ \\
Exchangeable cortical bone volume to surface & $1.850 \times 10^{-2}$ \\
Exchangeable to nonexchangeable cortical bone volume & $4.600 \times 10^{-3}$ \\
Nonexchangeable cortical bone volume to plasma & $8.210 \times 10^{-5}$ \\
Nonexchangeable trabecular bone volume to plasma & $4.930 \times 10^{-4}$ \\
\hline
\end{tabular}

The biokinetics of radioactive progeny of ${ }^{226} \mathrm{Ra}$ produced in the body is assumed to differ from that of ${ }^{226} \mathrm{Ra}$. Radon-222 produced in exchangeable and non-exchangeable bone volume compartments is assumed to migrate to blood at rates of 1.5 and $0.36 \mathrm{~d}^{-1}$, respectively. Radon-222 produced in soft tissues or bone surface is assumed to be removed to blood at the rate $100 \mathrm{~d}^{-1}$. Radon reaching blood is assumed to be removed from the body by exhalation at the rate $1 \mathrm{~min}^{-1}$. Other radioactive progeny of ${ }^{226} \mathrm{Ra}$ are assumed to be removed to blood at the rate of bone turnover if produced in bone volume, but if produced in other compartments they are assumed to transfer rapidly to blood $\left(1000 \mathrm{~d}^{-1}\right)$ and to behave according to their own characteristic biological behavior. For example, ${ }^{210} \mathrm{~Pb}$ that is transferred to blood after being produced in soft tissues or bone surface is assumed to behave as described in the ICRP's current 
biokinetic model for lead (ICRP 1993a). Additional details concerning the assumed behavior of ${ }^{226} \mathrm{Ra}$ progeny produced in the body are given on pp. 86-87 of ICRP Publication 67 (1993a).

Model predictions of retention and excretion of ${ }^{226} \mathrm{Ra}$ following acute inhalation of soluble and moderately soluble forms by a worker are given in Tables C.4 and C.5, respectively. The assumed particle size in each case is $5 \mu \mathrm{m}$ AMAD. Estimated 50-y effective doses for these same cases are given in Table C.6.

Table C.4 Model predictions of retention and excretion of ${ }^{226} \mathrm{Ra}$ (fraction of intake) following acute inhalation of a relatively soluble form (Type F, $5 \mu \mathrm{m}$ AMAD)

\begin{tabular}{rccc}
\hline Day after intake & $\begin{array}{c}\text { 24-h urinary } \\
\text { excretion }\end{array}$ & $\begin{array}{c}\text { 24-h fecal } \\
\text { excretion }\end{array}$ & Retained in body \\
\hline 1 & $4.9 \mathrm{E}-03$ & $1.0 \mathrm{E}-01$ & $5.0 \mathrm{E}-01$ \\
2 & $8.3 \mathrm{E}-04$ & $1.3 \mathrm{E}-01$ & $2.9 \mathrm{E}-01$ \\
3 & $5.7 \mathrm{E}-04$ & $8.1 \mathrm{E}-02$ & $1.8 \mathrm{E}-01$ \\
5 & $2.8 \mathrm{E}-04$ & $2.6 \mathrm{E}-02$ & $9.1 \mathrm{E}-02$ \\
7 & $1.4 \mathrm{E}-04$ & $1.0 \mathrm{E}-02$ & $6.2 \mathrm{E}-02$ \\
10 & $5.5 \mathrm{E}-05$ & $3.5 \mathrm{E}-03$ & $4.7 \mathrm{E}-02$ \\
15 & $1.9 \mathrm{E}-05$ & $9.2 \mathrm{E}-04$ & $3.9 \mathrm{E}-02$ \\
20 & $1.2 \mathrm{E}-05$ & $4.9 \mathrm{E}-04$ & $3.6 \mathrm{E}-02$ \\
30 & $9.7 \mathrm{E}-06$ & $3.6 \mathrm{E}-04$ & $3.2 \mathrm{E}-02$ \\
40 & $8.1 \mathrm{E}-06$ & $3.0 \mathrm{E}-04$ & $2.8 \mathrm{E}-02$ \\
50 & $6.9 \mathrm{E}-06$ & $2.5 \mathrm{E}-04$ & $2.5 \mathrm{E}-02$ \\
60 & $5.8 \mathrm{E}-06$ & $2.1 \mathrm{E}-04$ & $2.3 \mathrm{E}-02$ \\
70 & $4.9 \mathrm{E}-06$ & $1.8 \mathrm{E}-04$ & $2.1 \mathrm{E}-02$ \\
80 & $4.2 \mathrm{E}-06$ & $1.5 \mathrm{E}-04$ & $1.9 \mathrm{E}-02$ \\
90 & $3.5 \mathrm{E}-06$ & $1.3 \mathrm{E}-04$ & $1.8 \mathrm{E}-02$ \\
100 & $3.0 \mathrm{E}-06$ & $1.1 \mathrm{E}-04$ & $1.7 \mathrm{E}-02$ \\
\hline
\end{tabular}


Table C.5 Model predictions of retention and excretion of ${ }^{226} \mathrm{Ra}$ (fraction of intake) following acute inhalation of a moderately soluble form (Type M, $5 \mu \mathrm{m}$ AMAD)

\begin{tabular}{ccccc}
\hline Day after intake & $\begin{array}{c}\text { 24-h urinary } \\
\text { excretion }\end{array}$ & $\begin{array}{c}\text { 24-h fecal } \\
\text { excretion }\end{array}$ & $\begin{array}{c}\text { Retained in } \\
\text { lungs }\end{array}$ & $\begin{array}{c}\text { Retained in } \\
\text { body }\end{array}$ \\
\hline 1 & $1.6 \mathrm{E}-03$ & $1.1 \mathrm{E}-01$ & $5.8 \mathrm{E}-02$ & $5.0 \mathrm{E}-01$ \\
2 & $3.1 \mathrm{E}-04$ & $1.5 \mathrm{E}-01$ & $5.6 \mathrm{E}-02$ & $2.7 \mathrm{E}-01$ \\
3 & $2.1 \mathrm{E}-04$ & $8.0 \mathrm{E}-02$ & $5.5 \mathrm{E}-02$ & $1.6 \mathrm{E}-01$ \\
5 & $1.1 \mathrm{E}-04$ & $1.8 \mathrm{E}-02$ & $5.3 \mathrm{E}-02$ & $9.3 \mathrm{E}-02$ \\
7 & $5.7 \mathrm{E}-05$ & $5.4 \mathrm{E}-03$ & $5.2 \mathrm{E}-02$ & $7.6 \mathrm{E}-02$ \\
10 & $2.7 \mathrm{E}-05$ & $1.9 \mathrm{E}-03$ & $5.0 \mathrm{E}-02$ & $6.8 \mathrm{E}-02$ \\
15 & $1.4 \mathrm{E}-05$ & $9.3 \mathrm{E}-04$ & $4.6 \mathrm{E}-02$ & $6.2 \mathrm{E}-02$ \\
20 & $1.1 \mathrm{E}-05$ & $7.2 \mathrm{E}-04$ & $4.3 \mathrm{E}-02$ & $5.8 \mathrm{E}-02$ \\
30 & $9.5 \mathrm{E}-06$ & $5.7 \mathrm{E}-04$ & $3.8 \mathrm{E}-02$ & $5.1 \mathrm{E}-02$ \\
40 & $8.2 \mathrm{E}-06$ & $4.7 \mathrm{E}-04$ & $3.4 \mathrm{E}-02$ & $4.6 \mathrm{E}-02$ \\
50 & $7.2 \mathrm{E}-06$ & $3.9 \mathrm{E}-04$ & $3.1 \mathrm{E}-02$ & $4.2 \mathrm{E}-02$ \\
60 & $6.3 \mathrm{E}-06$ & $3.3 \mathrm{E}-04$ & $2.8 \mathrm{E}-02$ & $3.8 \mathrm{E}-02$ \\
70 & $5.6 \mathrm{E}-06$ & $2.8 \mathrm{E}-04$ & $2.6 \mathrm{E}-02$ & $3.5 \mathrm{E}-02$ \\
80 & $5.0 \mathrm{E}-06$ & $2.5 \mathrm{E}-04$ & $2.4 \mathrm{E}-02$ & $3.2 \mathrm{E}-02$ \\
90 & $4.5 \mathrm{E}-06$ & $2.1 \mathrm{E}-04$ & $2.2 \mathrm{E}-02$ & $3.0 \mathrm{E}-02$ \\
100 & $4.1 \mathrm{E}-06$ & $1.9 \mathrm{E}-04$ & $2.0 \mathrm{E}-02$ & $2.8 \mathrm{E}-02$ \\
\hline
\end{tabular}

Table C.6 Effective dose coefficients for inhaled ${ }^{226} \operatorname{Ra}(5 \mu \mathrm{m}$ AMAD)

\begin{tabular}{cc}
\hline Absorption type & Effective dose $(\mathbf{S v} / \mathbf{B q})$ \\
\hline F & $4.4 \mathrm{E}-07$ \\
M & $2.2 \mathrm{E}-06$ \\
\hline
\end{tabular}

\section{C.4. Biokinetic and Dosimetric Data for ${ }^{230} \mathrm{Th}$}

Data on clearance of inhaled thorium compounds from the respiratory tract in laboratory animals and human subjects generally indicate moderate (Type $\mathrm{M}$ ) to low (Type S) solubility in the lungs (ICRP 1995b). Measurements on laboratory animals and human subjects indicate low absorption of thorium from the gastrointestinal tract to blood. The ICRP applies an absorption fraction of 0.0005 to thorium for the cases of ingestion or inhalation of moderately soluble or relatively insoluble forms by adults (ICRP 1995a).

The systemic biokinetic model for thorium currently recommended by the ICRP is described in ICRP Publication 69 (1995a). The model structure is shown in Figure C.1. Parameter values for thorium are given in Table C.7. 


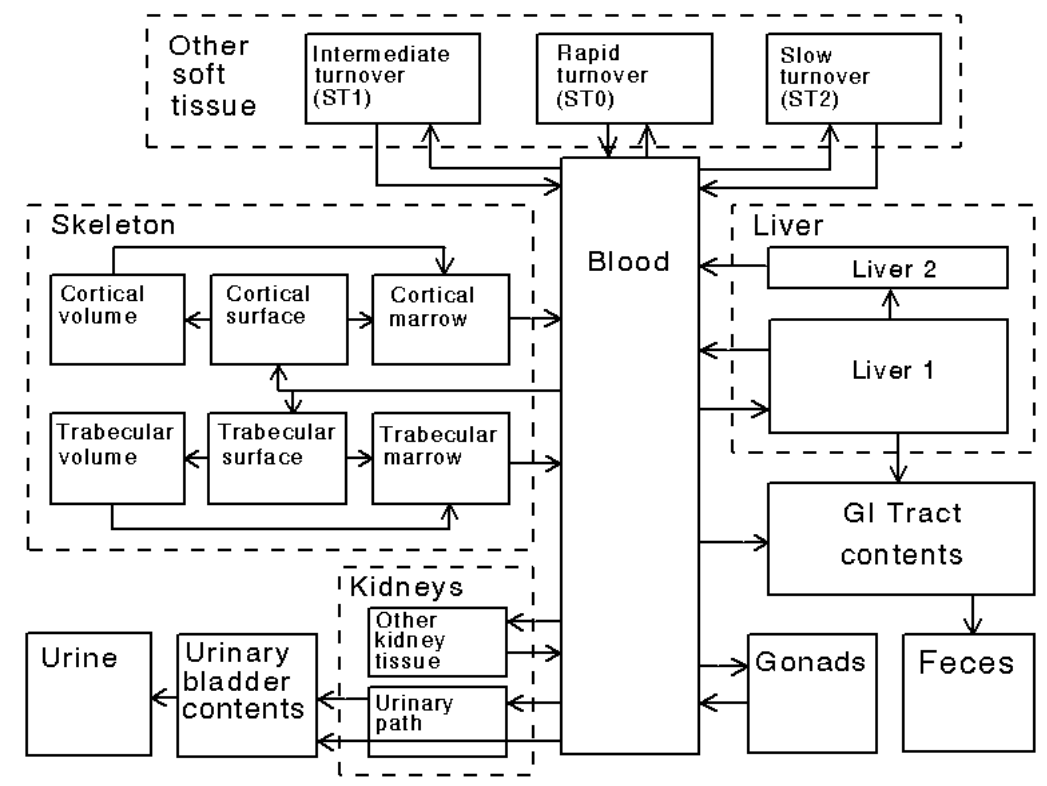

Figure C.1 Structure of the systemic biokinetic model for thorium (ICRP 1995a).

The biokinetics of radioactive progeny of ${ }^{230} \mathrm{Th}$ produced in the body is assumed to differ from that of ${ }^{230} \mathrm{Th}$. The general scheme for treatment of progeny of ${ }^{230} \mathrm{Th}$ is the same as that described above regarding progeny of ${ }^{226} \mathrm{Ra}$ produced in the body. Thorium-230 decays to ${ }^{226} \mathrm{Ra}$, which is assumed to be removed to blood at the rate of bone turnover if produced in bone volume but if produced in other compartments is assumed to transfer rapidly to blood and to behave according to the transfer coefficients for radium given in Table C.3. Subsequent members of the ${ }^{230} \mathrm{Th}$ chain are assumed to behave as described in Section C. 3 for ${ }^{226}$ Ra progeny. Additional details concerning the assumed behavior of thorium progeny produced in the body are given on pp. 47-48 of ICRP Publication 69 (1995a). 
Table C.7 Transfer coefficients in the biokinetic model for systemic thorium (ICRP 1995a)

\begin{tabular}{lc}
\hline \multicolumn{1}{c}{ Path } & $\begin{array}{c}\text { Transfer coefficient } \\
\left(\mathbf{d}^{-1}\right)\end{array}$ \\
\hline Blood to Liver 1 & $9.700 \times 10^{-2}$ \\
Blood to cortical surface & $6.793 \times 10^{-1}$ \\
Blood to trabecular surface & $6.793 \times 10^{-1}$ \\
Blood to urinary bladder contents & $1.067 \times 10^{-1}$ \\
Blood to kidneys (urinary path) & $6.793 \times 10^{-2}$ \\
Blood to other kidney tissue & $1.940 \times 10^{-2}$ \\
Blood to upper large intestine contents & $9.700 \times 10^{-3}$ \\
Blood to testes & $6.800 \times 10^{-4}$ \\
Blood to ovaries & $2.100 \times 10^{-4}$ \\
Blood to ST0 & $8.320 \times 10^{-1}$ \\
Blood to ST1 & $2.430 \times 10^{-1}$ \\
Blood to ST2 & $3.880 \times 10^{-2}$ \\
ST0 to blood & $4.620 \times 10^{-1}$ \\
Kidneys urinary path to urinary bladder contents & $4.620 \times 10^{-2}$ \\
Other kidney tissue to blood & $3.800 \times 10^{-4}$ \\
ST1 to blood & $9.500 \times 10^{-4}$ \\
ST2 to blood & $1.900 \times 10^{-5}$ \\
Trabecular surface to volume & $2.470 \times 10^{-4}$ \\
Trabecular surface to marrow & $4.930 \times 10^{-4}$ \\
Cortical surface to volume & $4.110 \times 10^{-5}$ \\
Cortical surface to marrow & $8.210 \times 10^{-5}$ \\
Trabecular volume to marrow & $4.930 \times 10^{-4}$ \\
Cortical volume to marrow & $8.210 \times 10^{-5}$ \\
Bone marrow compartments to blood & $7.600 \times 10^{-3}$ \\
Liver 1 to Liver 2 & $9.500 \times 10^{-4}$ \\
Liver 1 to small intestine contents & $4.750 \times 10^{-4}$ \\
Liver 1 to blood & $4.750 \times 10^{-4}$ \\
Liver 2 to blood & $2.110 \times 10^{-4}$ \\
Testes or ovaries to blood & $1.900 \times 10^{-4}$ \\
\hline & \\
\hline
\end{tabular}

Model predictions of retention and excretion of ${ }^{230}$ Th following acute inhalation of moderately soluble (Type M) and relatively insoluble (Type $\mathrm{S}$ ) forms by a worker are given in Tables C.8 and C.9, respectively. The assumed particle size in each case is $5 \mu \mathrm{m}$ AMAD. Estimated 50-y effective doses for these same cases are given in Table C.10. 
Table C.8 Model predictions of retention and excretion of ${ }^{230} \mathrm{Th}$ (fraction of intake) following acute inhalation of a moderately soluble form (Type M, $5 \mu \mathrm{m}$ AMAD)

\begin{tabular}{rcccc}
\hline $\begin{array}{c}\text { Day after } \\
\text { intake }\end{array}$ & $\begin{array}{c}\text { 24-h urinary } \\
\text { excretion }\end{array}$ & $\begin{array}{c}\text { 24-h fecal } \\
\text { excretion }\end{array}$ & $\begin{array}{c}\text { Retained in } \\
\text { lungs }\end{array}$ & $\begin{array}{c}\text { Retained in } \\
\text { body }\end{array}$ \\
\hline 1 & $1.1 \mathrm{E}-03$ & $1.1 \mathrm{E}-01$ & $5.8 \mathrm{E}-02$ & $5.0 \mathrm{E}-01$ \\
2 & $2.3 \mathrm{E}-04$ & $1.5 \mathrm{E}-01$ & $5.6 \mathrm{E}-02$ & $2.6 \mathrm{E}-01$ \\
3 & $1.4 \mathrm{E}-04$ & $8.0 \mathrm{E}-02$ & $5.5 \mathrm{E}-02$ & $1.5 \mathrm{E}-01$ \\
5 & $9.7 \mathrm{E}-05$ & $1.3 \mathrm{E}-02$ & $5.3 \mathrm{E}-02$ & $9.2 \mathrm{E}-02$ \\
7 & $7.5 \mathrm{E}-05$ & $2.3 \mathrm{E}-03$ & $5.2 \mathrm{E}-02$ & $8.3 \mathrm{E}-02$ \\
10 & $5.8 \mathrm{E}-05$ & $5.7 \mathrm{E}-04$ & $5.0 \mathrm{E}-02$ & $8.0 \mathrm{E}-02$ \\
15 & $4.5 \mathrm{E}-05$ & $4.2 \mathrm{E}-04$ & $4.6 \mathrm{E}-02$ & $7.7 \mathrm{E}-02$ \\
20 & $3.8 \mathrm{E}-05$ & $3.6 \mathrm{E}-04$ & $4.3 \mathrm{E}-02$ & $7.5 \mathrm{E}-02$ \\
30 & $3.0 \mathrm{E}-05$ & $2.8 \mathrm{E}-04$ & $3.8 \mathrm{E}-02$ & $7.2 \mathrm{E}-02$ \\
40 & $2.4 \mathrm{E}-05$ & $2.1 \mathrm{E}-04$ & $3.4 \mathrm{E}-02$ & $6.9 \mathrm{E}-02$ \\
50 & $2.0 \mathrm{E}-05$ & $1.6 \mathrm{E}-04$ & $3.1 \mathrm{E}-02$ & $6.7 \mathrm{E}-02$ \\
60 & $1.7 \mathrm{E}-05$ & $1.3 \mathrm{E}-04$ & $2.8 \mathrm{E}-02$ & $6.5 \mathrm{E}-02$ \\
70 & $1.5 \mathrm{E}-05$ & $1.0 \mathrm{E}-04$ & $2.6 \mathrm{E}-02$ & $6.4 \mathrm{E}-02$ \\
80 & $1.4 \mathrm{E}-05$ & $8.0 \mathrm{E}-05$ & $2.4 \mathrm{E}-02$ & $6.3 \mathrm{E}-02$ \\
90 & $1.2 \mathrm{E}-05$ & $6.4 \mathrm{E}-05$ & $2.2 \mathrm{E}-02$ & $6.2 \mathrm{E}-02$ \\
100 & $1.1 \mathrm{E}-05$ & $5.2 \mathrm{E}-05$ & $2.05-02$ & $6.1 \mathrm{E}-02$ \\
\hline
\end{tabular}

Table C.9 Model predictions of retention and excretion of ${ }^{230} \mathrm{Th}$ (fraction of intake) following acute inhalation of a relatively insoluble form (Type $S, 5 \mu \mathrm{m}$ AMAD)

\begin{tabular}{ccccc}
\hline $\begin{array}{c}\text { Day after } \\
\text { intake }\end{array}$ & $\begin{array}{c}\text { 24-h urinary } \\
\text { excretion }\end{array}$ & $\begin{array}{c}\text { 24-h fecal } \\
\text { excretion }\end{array}$ & $\begin{array}{c}\text { Retained in } \\
\text { lungs }\end{array}$ & $\begin{array}{c}\text { Retained in } \\
\text { body }\end{array}$ \\
\hline 1 & $1.3 \mathrm{E}-05$ & $1.1 \mathrm{E}-01$ & $6.4 \mathrm{E}-02$ & $4.9 \mathrm{E}-01$ \\
2 & $3.3 \mathrm{E}-06$ & $1.6 \mathrm{E}-01$ & $6.3 \mathrm{E}-02$ & $2.5 \mathrm{E}-01$ \\
3 & $1.9 \mathrm{E}-06$ & $8.4 \mathrm{E}-02$ & $6.2 \mathrm{E}-02$ & $1.4 \mathrm{E}-01$ \\
5 & $1.4 \mathrm{E}-06$ & $1.4 \mathrm{E}-02$ & $6.1 \mathrm{E}-02$ & $7.3 \mathrm{E}-02$ \\
7 & $1.1 \mathrm{E}-06$ & $2.5 \mathrm{E}-03$ & $6.0 \mathrm{E}-02$ & $6.3 \mathrm{E}-02$ \\
10 & $9.2 \mathrm{E}-07$ & $6.5 \mathrm{E}-04$ & $5.8 \mathrm{E}-02$ & $6.0 \mathrm{E}-02$ \\
15 & $7.7 \mathrm{E}-07$ & $4.9 \mathrm{E}-04$ & $5.5 \mathrm{E}-02$ & $5.7 \mathrm{E}-02$ \\
20 & $6.9 \mathrm{E}-07$ & $4.4 \mathrm{E}-04$ & $5.3 \mathrm{E}-02$ & $5.5 \mathrm{E}-02$ \\
30 & $5.9 \mathrm{E}-07$ & $3.5 \mathrm{E}-04$ & $4.9 \mathrm{E}-02$ & $5.1 \mathrm{E}-02$ \\
40 & $5.3 \mathrm{E}-07$ & $2.8 \mathrm{E}-04$ & $4.6 \mathrm{E}-02$ & $4.8 \mathrm{E}-02$ \\
50 & $4.8 \mathrm{E}-07$ & $2.3 \mathrm{E}-04$ & $4.4 \mathrm{E}-02$ & $4.5 \mathrm{E}-02$ \\
60 & $4.4 \mathrm{E}-07$ & $1.9 \mathrm{E}-04$ & $4.2 \mathrm{E}-02$ & $4.3 \mathrm{E}-02$ \\
70 & $4.1 \mathrm{E}-07$ & $1.5 \mathrm{E}-04$ & $4.0 \mathrm{E}-02$ & $4.1 \mathrm{E}-02$ \\
80 & $3.9 \mathrm{E}-07$ & $1.3 \mathrm{E}-04$ & $3.9 \mathrm{E}-02$ & $4.0 \mathrm{E}-02$ \\
90 & $3.8 \mathrm{E}-07$ & $1.1 \mathrm{E}-04$ & $3.8 \mathrm{E}-02$ & $3.9 \mathrm{E}-02$ \\
100 & $3.7 \mathrm{E}-07$ & $9.1 \mathrm{E}-05$ & $3.7 \mathrm{E}-02$ & $3.8 \mathrm{E}-02$ \\
\hline
\end{tabular}


Table C.10 Effective dose coefficients for inhaled ${ }^{230} \mathrm{Th}$ (5 $\mu \mathrm{m}$ AMAD)

\begin{tabular}{cc}
\hline Absorption type & $\begin{array}{c}\text { Effective dose } \\
\text { (Sv/Bq) }\end{array}$ \\
\hline $\mathrm{M}$ & $2.8 \mathrm{E}-05$ \\
$\mathrm{~S}$ & $7.2 \mathrm{E}-06$ \\
\hline
\end{tabular}

\section{C.5. Exposure to ${ }^{222} \mathrm{Rn}$ Progeny}

Radon-222 is a naturally occurring radioactive gas, formed as the decay product of ${ }^{226} \mathrm{Ra}$. Because ${ }^{222} \mathrm{Rn}$ is inert, nearly all inhaled ${ }^{222} \mathrm{Rn}$ is subsequently exhaled. However, airborne ${ }^{222} \mathrm{Rn}$ decays into a series of solid short-lived radioisotopes $\left({ }^{218} \mathrm{Po},{ }^{214} \mathrm{~Pb},{ }^{214} \mathrm{Bi}\right.$, and $\left.{ }^{214} \mathrm{Po}\right)$ that are inhaled along with ${ }^{222} \mathrm{Rn}$ and deposit in the respiratory tract. Because of their short halflives, these radionuclides may decay to a significant extent in the respiratory tract before clearance can take place. Two of these progeny, ${ }^{218} \mathrm{Po}$ and ${ }^{214} \mathrm{Po}$, are alpha emitters and represent most of the dose to the lungs from inhaled ${ }^{222} \mathrm{Rn}$ and its progeny.

The ICRP currently does not apply its standard biokinetic and dosimetric modeling scheme for internal emitters to the case of inhalation of ${ }^{222} \mathrm{Rn}$ progeny. Rather, the ICRP recommends that assessment of risk from exposure to radon progeny should be based on epidemiological studies relating excess lung cancer in miners to radon exposure (ICRP 1993b, 1994a).

Historically, the concentration of ${ }^{222} \mathrm{Rn}$ progeny in air has been measured in Working Levels (WL), and exposure to ${ }^{222} \mathrm{Rn}$ progeny in air has been measured in Working Level Months (WLM). A Working Level is defined as any combination of the short-lived radioactive progeny in one liter of air that will result in the ultimate emission of $1.3 \mathrm{E}+05 \mathrm{MeV}$ of alpha energy $\left(1 \mathrm{WL}=2.083 \mathrm{E}-05 \mathrm{~J} / \mathrm{m}^{3}\right)$. A Working Level Month is defined as exposure for 1 working month (170 hours) to an airborne concentration of $1 \mathrm{WL}(1 \mathrm{WLM}=1 \mathrm{WL} \times 170$ hours $=0.00354$ $\left.\mathrm{J} \cdot \mathrm{h} / \mathrm{m}^{3}\right)$.

ICRP Publication 50 (1987) gives an estimate of effective dose per unit exposure to ${ }^{222} \mathrm{Rn}$ progeny of $6.4 \mathrm{mSv}$ per WLM (ICRP 1987). UNSCEAR uses a similar value of $5.7 \mathrm{mSv}$ per WLM for its dose evaluations (UNSCEAR 2000). ICRP Publication 65 (1993b) gives an estimated effective dose of $4 \mathrm{mSv}$ per WLM for workers.

Recall that the following primary reference guidance for limitation of radiation effects is used in this report as part of the basis for determining action levels from monitoring data for uranium (see Sections 1 and 2): The committed effective dose from intake of uranium during any 1-y period should not exceed $0.02 \mathrm{~Sv}$ as an average over any 5-y period and should not exceed 0.05 $\mathrm{Sv}$ in any single year, and the value $0.02 \mathrm{~Sv}$ should be used for planning purposes for any 1-y period. For consistency, the same primary reference guidance should be applied to other radionuclides encountered at uranium facilities. If the effective dose per unit exposure to ${ }^{222} \mathrm{Rn}$ progeny is taken as the rounded value $5 \mathrm{mSv}$ per WLM, an annual dose of $0.02 \mathrm{~Sv}$ would correspond to exposure of 4 WLM per year. Both the NRC (1991) and EPA (1988) have adopted limits of 4 WLM per year for exposure to ${ }^{222} \mathrm{Rn}$ in the workplace. 


\section{APPENDIX D: COMPARISON OF REFERENCE GUIDANCE IN THIS REPORT WITH U.S. FEDERAL AGENCY GUIDANCE AND REGULATIONS}

\section{D.1. U.S. Nuclear Regulatory Commission Regulatory Guides and Regulation \\ D.1.1. Regulatory Guide 8.11: Applications of Bioassay for Uranium}

Regulatory Guide 8.11 (USNRC, 1974) provides criteria for the development and implementation of a bioassay program for natural uranium isotopes at any uranium facility. The guidance is concerned with inhalation of uranium compounds and is programmatic in nature. Guidance is given on determination of whether bioassay procedures are necessary, who should participate in a bioassay program, selection of bioassay techniques, frequency of measurements, bioassay results that should initiate actions, and specific actions that should be taken at each action level.

The technical basis of Regulatory Guide 8.11 is WASH-1251, "Applications of Bioassay for Uranium" (Alexander 1974). The guidance in WASH-1251 and hence in Regulatory Guide 8.11 is consistent with the version of 10CFR20 in effect at the time. The radiological guidance in that version of 10CFR 20 was based on the concept of the dose to the critical organ introduced in ICRP Publication 2 (1959).

The guidance in Regulatory Guide 8.11 for avoidance of chemical toxicity from uranium was designed to limit the mass concentration of uranium in the kidneys to $3 \mu \mathrm{g} \mathrm{U} / \mathrm{g}$ kidney. The guidance was expressed in terms of the mass of uranium reaching blood.

Regulatory Guide 8.11 gives rules for selection of bioassay measurement techniques based on the purpose of measurements and the expected "transportability" (solubility) of inhaled uranium compounds. For example, if the purpose is to check the adequacy of the air sampling program and the airborne material is expected to be transportable (soluble) in the lungs, then urinary uranium should be measured. If the purpose is to check the air sampling program and the material is expected to be non-transportable (relatively insoluble) in the lungs, then an in vivo lung count is the preferred measurement, measurement of uranium in feces is the second choice, and measurement of uranium in urine is the third choice.

Rules also are given for measurement frequency on the basis of the type of measurement (urinary excretion or in vivo lung count), the average and maximum bioassay measurement of that type over the most recent quarter, and the solubility of the material in the lungs. Recommended measurement frequencies are given in bioassays per year at equally spaced intervals and vary from 1 to 12 for in vivo lung counts and from 2 to 52 for urinary excretion measurements.

Regulatory Guide 8.11 provides action points based on bioassay results for the case of acute intake of uranium and lists associated actions. Action points for limiting radiological risk are expressed as multiples of the annual Maximum Permissible Dose Commitment $\left(\mathrm{MPD}_{\mathrm{c}}\right)$ implied by the bioassay results. The $\mathrm{MPD}_{\mathrm{c}}$, taken from the version of $10 \mathrm{CFR} 20$ in effect at the time, is a 
$50-\mathrm{y}$ integrated dose of 15 rem to lung or 30 rem to bone. Action points designed to avoid chemical toxicity from intake of uranium are expressed in terms of the quantity $\mathrm{L}=2.7 \mathrm{mg}$ of uranium reaching blood, assuming that the inhaled material is soluble and $43 \%$ of inhaled uranium is absorbed to blood.

Specific action points implied by the methods of Regulatory Guide 8.11 generally are based on single intakes. The action points are determined from complex graphs and generally vary with the sampling period and solubility of the inhaled material. It is difficult to make meaningful comparisons of those action points with the action levels given in the present report.

\section{D.1.2 Regulatory Guide 8.22: Bioassay at Uranium Mills}

Regulatory Guide 8.22 provides criteria for the development and implementation of a bioassay program for workers exposed to natural uranium isotopes at a uranium mill. The guidance is applicable to portions of other uranium facilities where the possibility of exposure to yellowcake or ore dust exists.

The technical basis of Regulatory Guide 8.22 is NUREG-0874, Internal Dosimetry Model for Applications to Bioassay at Uranium Mills (Alexander et al. 1986). The primary radiological guidance is based on the concept of committed effective dose equivalent (CEDE) as defined in ICRP Publications 26 (1977) and applied in ICRP Publication 30 (1979, 1980, 1981, 1986). NUREG-0874 states that the dosimetric model adopted is "primarily" that published in ICRP Publication 30. For example, NUREG-0874 applies the respiratory model framework of ICRP Publication 30 but assigns different parameter values developed by the authors of NUREG-0874 specifically for application to low-fired yellowcake, high-fired yellowcake, and ore dust. The systemic biokinetic model applied in NUREG-0874 differs from the systemic model for uranium used in ICRP Publication 30 with regard to uptake and retention times of uranium in systemic tissues.

Insofar as comparisons are possible, specific numerical guidance in NUREG-0874 differs from Appendix B to 10CFR20, due largely to differences in the underlying biokinetic models. For example, NUREG-0874 defines special parameter values for high-fired and low-fired yellowcake and gives Derived Air Concentrations (DACs) of $1.63 \mathrm{~Bq} / \mathrm{m}^{3}\left(4.4 \times 10^{-11} \mu \mathrm{Ci} / \mathrm{mL}\right)$ for high-fired yellowcake and $2.85 \mathrm{~Bq} / \mathrm{m}^{3}\left(7.7 \times 10^{-11} \mu \mathrm{Ci} / \mathrm{mL}\right)$ for low-fired yellowcake. These two values do not correspond to any of the DACs listed or implied in Appendix B to 10CFR20 for natural isotopic mixtures of uranium. Both values fall between the DACs for ${ }^{234} \mathrm{U}$, ${ }^{235} \mathrm{U}$, or ${ }^{238} \mathrm{U}$ listed in Appendix B to 10CFR20 for Class W material $\left(11 \mathrm{~Bq} / \mathrm{m}^{3}\right.$ or $\left.3 \times 10^{-10} \mu \mathrm{Ci} / \mathrm{mL}\right)$ and Class Y material $\left(0.74 \mathrm{~Bq} / \mathrm{m}^{3}\right.$ or $\left.2 \times 10^{-11} \mu \mathrm{Ci} / \mathrm{mL}\right)$.

NUREG-0874 provides material-specific and exposure-specific (acute or continuous) limiting values for intake, air concentration, urinary excretion rate, lung burden, and other measurable or calculated quantities. The materials considered are high-fired yellowcake, low-fired yellowcake, ore dust, and mixtures of these materials.

Regulatory Guide 8.22 condenses the large set of limiting values given in NUREG-0874 to a small set of action levels, resulting in differences from some of the material-specific and exposure-specific values given in NUREG-0874. Action levels are tabulated in Regulatory 
Guide 8.22 for urinary uranium expressed as mass of uranium per unit volume of urine $(\mu \mathrm{g} / \mathrm{L})$ and externally measured uranium in the chest expressed as total activity in the chest (nCi or Bq). Modifications and simplifications of limiting values proposed in NUREG-0874 are based mainly on practical considerations such as the uncertainties in measurements of uranium in urine or in the lungs at relatively low levels of intake, the need to provide simple guidance, and the relatively high cost of in vivo lung counts.

The action levels for urinary excretion rates and lung burdens given in Regulatory Guide 8.22 are intended to ensure that the average air concentration of yellowcake does not exceed $3.7 \times 10^{-6} \mathrm{~Bq} / \mathrm{mL}\left(10^{-10} \mu \mathrm{Ci} / \mathrm{mL}\right)$ for a 40 -h workweek and the average air concentration of ore dust does not exceed $3.7 \times 10^{-6} \mathrm{~Bq} / \mathrm{mL}$ for a period of one calendar quarter. The activity concentration $3.7 \times 10^{-6} \mathrm{~Bq} \mathrm{U} / \mathrm{mL}$ corresponds to a mass concentration of $0.15 \mathrm{mg} \mathrm{U} / \mathrm{m}^{3}$ for yellowcake or ore dust. For comparison, Appendix B to 10CFR20 (Footnote 3) specifies a limit of $0.20 \mathrm{mg} \mathrm{U} / \mathrm{m}^{3}$ for airborne uranium containing no more $5 \%{ }^{235} \mathrm{U}$ by weight.

Regulatory Guide 8.22 indicates that site-specific action levels based on models and methods of NUREG-0874 may be proposed to the NRC:

"Action levels and actions [tabulated in Regulatory Guide 8.22] are acceptable as a basis for a uranium mill bioassay program. Proposals for other action levels and actions from an applicant will be considered on a specific-case basis if accompanied by a description of how the information in NUREG-0874 was used to derive those different criteria."

Action levels listed in Regulatory Guide 8.22 are compared in Table D.1 with values recommended in the present report. Overall, recommendations in the present report are more restrictive than those given in Regulatory Guide 8.22. However, the values from the present report are for poorly characterized forms of airborne uranium and thus are based on worst-case assumptions, while those from Regulatory Guide 8.22 are for more narrowly determined exposure situations. 


\begin{tabular}{|c|c|c|}
\hline & Regulatory Guide 8.22 & This report \\
\hline $\begin{array}{l}\text { Primary radiological and } \\
\text { chemical reference } \\
\text { guidance }\end{array}$ & Appendix B to 10CFR20 & $\begin{array}{l}\text { ICRP Pub. } 60 \text { and limiting } \\
\text { concentration of } 1.0 \mu \mathrm{g} \mathrm{U} / \mathrm{g} \text { kidney }\end{array}$ \\
\hline Biokinetic models applied & $\begin{array}{l}\text { Variations of ICRP Pub. } 30 \\
\text { models developed by authors of } \\
\text { NUREG-0874 }\end{array}$ & $\begin{array}{l}\text { Respiratory model from ICRP } \\
\text { Pub. } 66 \text {, alimentary tract model fron } \\
\text { ICRP Pub. 100, and systemic } \\
\text { biokinetic model from ICRP Pub. } 6\end{array}$ \\
\hline Urine sampling frequency & $\begin{array}{l}\text { Depends on potential for U intake } \\
\text { and solubility of inhaled material. } \\
\text { For workers in ore dust or } \\
\text { yellowcake areas, sampling at } \\
\text { least monthly and more often for } \\
\text { specified conditions }\end{array}$ & $\begin{array}{l}\text { Depends on potential for U intake. } \\
\text { Weekly sampling recommended for } \\
\text { workers routinely in areas with } \\
\text { elevated airborne U (e.g., miners or } \\
\text { millers). More frequent sampling } \\
\text { after known elevated intake. }\end{array}$ \\
\hline Timing of urine sampling & $\begin{array}{l}\text { At least } 36 \mathrm{~h} \text { after most recent } \\
\text { work in potentially contaminated } \\
\text { areas }\end{array}$ & $\begin{array}{l}48-72 \mathrm{~h} \text { after the last potential } \\
\text { exposure or pooled samples } \\
\text { representative of full week }\end{array}$ \\
\hline Forms of $\mathrm{U}$ addressed & Yellowcake and ore dust & All forms \\
\hline $\begin{array}{l}\text { Maximum acceptable level } \\
\text { of airborne } \mathrm{U}\end{array}$ & $\begin{array}{l}0.15 \mathrm{mg} / \mathrm{m}^{3} \text { or } 3.7 \mathrm{~Bq} / \mathrm{m}^{3} \\
\text { averaged over any } 40-\mathrm{h} \\
\text { workweek for yellowcake or any } \\
\text { 3-month period for ore dust }\end{array}$ & $\begin{array}{l}{ }^{b} 0.2 \mathrm{mg} / \mathrm{m}^{3} \text { or } 12 \mathrm{~Bq} / \mathrm{m}^{3} \text { averaged } \\
\text { over a } 40 \text {-h workweek but smaller } \\
\text { acceptable values if averaged over } \\
\text { longer periods (see Figure D.1). }\end{array}$ \\
\hline $\begin{array}{l}\text { Investigation level }{ }^{a} \text { based } \\
\text { on urinary U }\end{array}$ & $15 \mu \mathrm{g} / \mathrm{L}$ & ${ }^{b} 10 \mu \mathrm{g} / \mathrm{L}$ or $0.6 \mathrm{~Bq} / \mathrm{L}$ \\
\hline $\begin{array}{l}\text { Immediate action level }{ }^{a} \\
\text { based on urinary } \mathrm{U}\end{array}$ & $35 \mu \mathrm{g} / \mathrm{L}$ & ${ }^{b} 33 \mu \mathrm{g} / \mathrm{L}$ or $1.5 \mathrm{~Bq} / \mathrm{L}$ \\
\hline $\begin{array}{l}\text { Investigation level }{ }^{a} \text { for } \\
\text { in vivo count of } \mathrm{U} \text { in chest }\end{array}$ & $330 \mathrm{~Bq}$ & ${ }^{b} 200 \mathrm{~Bq}$ \\
\hline $\begin{array}{l}\text { Immediate action level }{ }^{a} \text { for } \\
\text { in vivo count of } \mathrm{U} \text { in chest }\end{array}$ & $590 \mathrm{~Bq}$ & ${ }^{b} 500 \mathrm{~Bq}$ \\
\hline $\begin{array}{l}\text { Investigation level based on } \\
\text { fecal U }\end{array}$ & Not given & ${ }^{b} 0.025 \mathrm{~Bq} / \mathrm{g}$ \\
\hline $\begin{array}{l}\text { Immediate action level } \\
\text { based on fecal U }\end{array}$ & Not given & ${ }^{b} 0.06 \mathrm{~Bq} / \mathrm{g}$ \\
\hline
\end{tabular}

\footnotetext{
${ }^{a}$ Terminology differs from Regulatory Guide 8.22. Comparisons with present report based on corrective actions for different levels of urinary $U$ (see Tables 1 and 2 of Regulatory Guide 8.22).

${ }^{b}$ Default values based on worst-case assumptions for intake of an unknown form of uranium (Section 5). The methods described in Section 5 can be applied to site-specific data to demonstrate that different values are appropriate for a given facility or work area.
} 


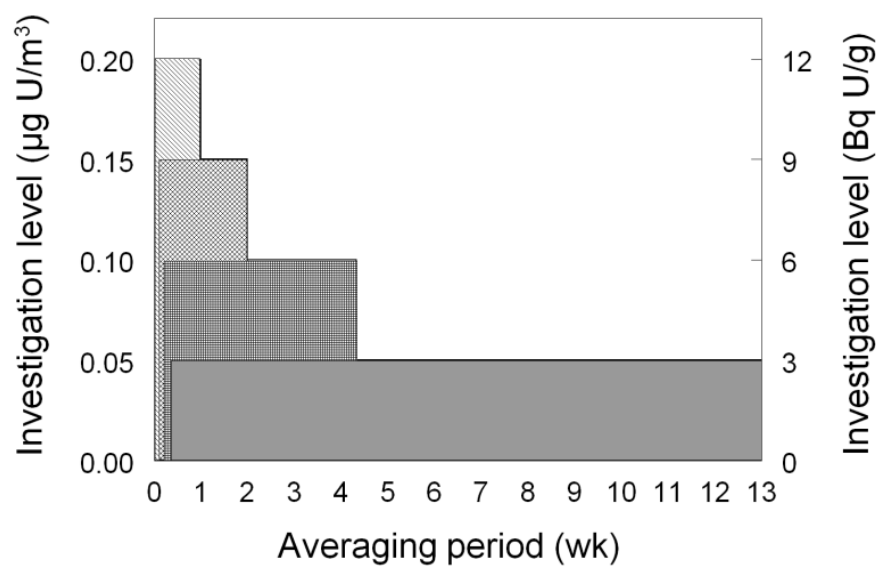

Figure D.1 For an unknown form of uranium, reference guidance values given in this report for the average concentration of uranium for different exposure periods. Regulatory Guide 8.22 limits the air concentration to $0.15 \mathrm{mg} \mathrm{U} / \mathrm{m}^{3}$ or $3.7 \mathrm{~Bq} \mathrm{U} / \mathrm{m}^{3}$ as an average over a 40-h workweek, but for any number of repeated workweeks.

\section{D.1.3. Appendix B to 10CFR20}

\section{D.1.3.1. Limitation of Radiation Doses}

Appendix B to 10CFR20 provides Annual Limits on Intake (ALIs) and Derived Air Concentrations (DACs) for radionuclides in the workplace or environment. The values are based on radiological guidance given in ICRP Publication 26 (1977) and biokinetic and dosimetric models of ICRP Publication 30 (1979, 1980, 1981, 1988).

The guidance in ICRP Publication 26 (1977) is based on the concept of committed effective dose equivalent (CEDE), defined as a weighted sum of committed dose equivalents to radiosensitive tissues. The tissue weighting factors (Column 2 of Table D.2) represent the relative contribution of the different tissues to the total detriment for the case of uniform irradiation of the whole body. Health effects are categorized as stochastic, meaning that the probability of occurrence is a function of dose (e.g., cancer), or nonstochastic, meaning that the effect is expected to occur when the dose reaches or exceeds a threshold value (e.g., cataracts). To prevent stochastic effects, the effective dose from exposure in a year is limited to $0.05 \mathrm{~Sv}$. To prevent nonstochastic effects, the dose equivalent to organs from intakes in a year is limited to $0.5 \mathrm{~Sv}$ except that the lens of the eye is limited to $0.15 \mathrm{~Sv}$. 
Table D.2 Tissue weighting factors given in ICRP Publications 26 (1977), 60 (1991), and 103 (2008)

\begin{tabular}{lccc}
\hline \multirow{2}{*}{ Organ or tissue } & \multicolumn{3}{c}{ Tissue weighting factor $\left(\mathbf{w}_{\mathbf{T}}\right.$ ) } \\
\cline { 2 - 4 } & ICRP Pub. 26 & ICRP Pub. 60 & ICRP Pub. 103 \\
\hline Gonads & 0.25 & 0.20 & 0.08 \\
Bone marrow (red) & 0.12 & 0.12 & 0.12 \\
Colon & -- & 0.12 & 0.12 \\
Lung & 0.12 & 0.12 & 0.12 \\
Stomach & -- & 0.12 & 0.12 \\
Urinary bladder & -- & 0.05 & 0.04 \\
Breast & 0.15 & 0.05 & 0.12 \\
Liver & -- & 0.05 & 0.04 \\
Esophagus & -- & 0.05 & 0.04 \\
Thyroid & 0.03 & 0.05 & 0.04 \\
Skin & -- & 0.01 & 0.01 \\
Bone surface & 0.03 & 0.01 & 0.01 \\
Brain & -- & -- & 0.01 \\
Salivary glands & -- & -- & 0.01 \\
Remainder & $0.30^{a}$ & $0.05^{b}$ & $0.12^{c}$ \\
\hline
\end{tabular}

${ }^{a}$ In ICRP Pub. 26 the $\mathrm{w}_{\mathrm{T}}$ for Remainder is applied to the average dose to the five remaining tissues receiving the highest dose, excluding the skin, lens of the eye, and the extremities.

${ }^{b}$ In ICRP Pub. 60 the $\mathrm{w}_{\mathrm{T}}$ for Remainder is applied to the mass-weighted average dose to adrenals, brain, extrathoracic airways, small intestine, kidneys, muscle, pancreas, spleen, thymus, and uterus, except when the following "splitting rule" applies: If one of these 10 tissues receives a dose greater than any of the 12 individual tissues for which weighting factors are specified, half of the weighting factor $(0.025)$ is applied to that tissue and the other half is applied to the mass-weighted committed equivalent dose in the rest of the Remainder tissues.

${ }^{c}$ In ICRP Pub. 103 the $\mathrm{w}_{\mathrm{T}}$ for Remainder is applied to the arithmetic mean of doses to adrenals, extrathoracic (ET) region, gallbladder, heart, kidneys, lymphatic nodes, muscle, oral mucosa, pancreas, prostate, small intestine, spleen, thymus, and uterus/cervix.

An occupational ALI for a radionuclide is defined in Appendix B of 10CFR20 as the annual intake by a reference worker that would result in either a committed effective dose equivalent of $0.05 \mathrm{~Sv}$ or a committed dose equivalent of $0.5 \mathrm{~Sv}$ to an organ or tissue. An occupational DAC for an inhaled radionuclide is the ALI divided by $2400 \mathrm{~m}^{3}$ as a reference value for annual intake of air during work hours.

Footnotes to Appendix B of 10CFR20 provide rules for calculating limiting values for a mixture of radionuclides based on the limiting values for individual radionuclides in the mixture. If the identity and concentration of each radionuclide in a mixture are known, the limiting values are derived as follows: For each radionuclide in the mixture, determine the ratio of the concentration present in the mixture and the concentration tabulated in Appendix B for that individual radionuclide. The sum of such ratios for all of the radionuclides in the mixture may not exceed 1.0. If the identity of each radionuclide in a mixture is known but the concentration of one or more of the radionuclides in the mixture is not known, the DAC for the mixture is the most restrictive of the limiting DACs for any radionuclide in the mixture. 
Inhalation dose coefficients used to calculate the ALIs and DACs for occupational intake given in 10CFR20 are based on a particle size of $1 \mu \mathrm{m}$ AMAD, which is the default particle size recommended in ICRP Publication 30. ALIs and DACs are given for each of three solubility classes of radioactive material addressed in the respiratory model used in ICRP Publication 30: Class D, Class W, and Class Y. These solubility classes represent material that is relatively soluble, moderately soluble, and relatively insoluble, respectively, in the lungs and hence are analogous to Types F, M, and S used in the ICRP's current respiratory tract model. The letters $\mathrm{D}, \mathrm{W}$, and $\mathrm{Y}$ refer to retention times of days, weeks, or years, respectively, in the pulmonary region of the lung.

In the present report, guidance values developed to limit radiation doses to workers from internally deposited uranium isotopes are based on primary radiological guidance given in ICRP Publication 60 (1991), which superseded ICRP Publication 26 (1977). The biokinetic models applied here are the respiratory tract model described in ICRP Publication 66 (1994a), the alimentary tract model described in ICRP Publication 100 (2006), and the systemic biokinetic model for uranium described in ICRP Publication 69 (1995a). The default particle size for airborne material is $5 \mu \mathrm{m}$ AMAD.

The primary guidance in ICRP Publication 60 is based on the concept of effective dose. This is the same concept as the CEDE of ICRP Publication 26, but the tissue weighting factors (Column 3 of Table D.2) and the limit on the effective dose differ from those of ICRP Publication 26. The committed effective dose from occupational intakes during any 1-y period (the "annual effective dose") is limited to $0.02 \mathrm{~Sv}$ as an average over any 5 -y period and to 0.05 Sv for any single year. Although ICRP Publication 60 provides guidance for prevention of nonstochastic effects, the guidance for prevention of stochastic effects generally is more restrictive. Thus, the ALI is calculated simply as $\mathrm{E}_{\text {limit }} / \mathrm{e}(50)$, where $\mathrm{E}_{\text {limit }}$ is the limiting effective dose $(0.02$ $\mathrm{Sv}$ in this case) and e(50) is the committed effective dose coefficient (Sv/Bq). The DAC for occupational intake is calculated as:

$$
D A C=A L I \div \text { Annual air intake }=\left[E_{\text {limit }} \div e(50) \div 2400 m^{3}\right]
$$

ALIs and DACs are not applied explicitly in the present report, but radiation-based action levels for uranium in air as defined in this report are conceptually the same as the DAC. These action levels are calculated from Equation D.1, with $\mathrm{E}_{\text {limit }}=0.02 \mathrm{~Sv}$ used to derive an investigation level and $\mathrm{E}_{\text {limit }}=0.05 \mathrm{~Sv}$ used to derive an action level.

Table D.3 compares action levels based on the methods and models of the present report with DACs given in Appendix B to 10CFR20. Comparisons are made for relatively soluble, moderately soluble, and relatively insoluble forms of each of the natural uranium isotopes. For relatively soluble forms of uranium the DACs from 10CFR20 fall between the investigation and immediate action levels based on present methods for all three isotopes. For moderately soluble forms the DACs from 10CFR20 are close to the immediate action levels based on the present methods. For relatively insoluble material the DACs from 10CFR20 are 40-50\% lower than the investigation levels based on the present methods. 


\section{Table D.3 Comparison of action levels for ${ }^{234} \mathrm{U},{ }^{235} \mathrm{U}$, and ${ }^{238} \mathrm{U}$ in air derived in this report with DACs from Appendix B of 10CFR20}

Relatively soluble

DAC (10CFR20, Class D, $1 \mu \mathrm{m})$

Investigation level (This report, Type F, $5 \mu \mathrm{m}$ )

Immediate action level (This report, Type F, $5 \mu \mathrm{m}$ )

Moderately soluble

DAC (10CFR20, Class W, $1 \mu \mathrm{m})$

Investigation level (This report, Type M, $5 \mu \mathrm{m}$ )

Immediate action level (This report, Type M, $5 \mu \mathrm{m}$ )

Relatively insoluble

DAC (10CFR20, Class Y, $1 \mu \mathrm{m})$

Investigation level (This report, Type $S, 5 \mu \mathrm{m}$ )

Immediate action level (This report, Type $S, 5 \mu \mathrm{m}$ )

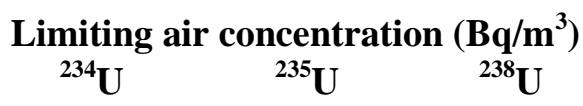

19

13

33

22

14

35

14

36

11

4.0

11

4.6

11

9.9

12

5.2

13

$\begin{array}{lll}0.74 & 0.74 & 0.74 \\ 1.2 & 1.4 & 1.5 \\ 3.0 & 3.4 & 3.7\end{array}$

\section{D.1.3.2. Avoidance of Chemical Toxicity}

Appendix B to 10CFR20 (Footnote 3) states that chemical toxicity may be the limiting factor for exposure to soluble mixtures of ${ }^{234} \mathrm{U},{ }^{235} \mathrm{U}$, and ${ }^{238} \mathrm{U}$ in air. A limiting air concentration of $0.2 \mathrm{mg} \mathrm{U} / \mathrm{m}^{3}$ is given for mixtures in which the ${ }^{235} \mathrm{U}$ content is no greater than $5 \%$ by mass as an average over a 40-h workweek. Footnote 3 of Appendix B also gives the following formula for the specific activity of ${ }^{235} \mathrm{U}$-enriched uranium (converted here from conventional units to SI units):

$$
S p A=\left(3.7 \times 10^{4}\right)\left(0.4+0.38 E+0.0034 E^{2}\right) B q / g
$$

where, $\mathrm{E}$ is the percentage of ${ }^{235} \mathrm{U}$ by weight and is $\geq 0.72$. Equation D. 2 can be used to determine whether the DAC for a given level of ${ }^{235} \mathrm{U}$ enrichment is more restrictive than a mass concentration limit of $0.2 \mathrm{mg} \mathrm{U} / \mathrm{m}^{3}$. The same formula is applied in the present report to depleted, natural, or enriched uranium except for the number of digits given for the first term of the second factor [0.43 in Equation 5.2 compared with 0.4 in Equation D.2].

The action levels given in the present report in terms of the mass concentration of uranium in air are more stringent overall than the limiting value given in 10CFR20, i.e., $0.2 \mathrm{mg} \mathrm{U} / \mathrm{m}^{3}$ as an average over a 40-h workweek. In 10CFR20 that value applies to the average air concentration over any number of weeks per year, or over an entire career. The 40-h workweek simply specifies the block of time over which the average should be calculated. In the present report the same value is recommended as an immediate action level for an unknown form of airborne uranium, but the recommended limit decreases with the length of the exposure period (i.e., the averaging period) up to an exposure period of $3 \mathrm{mo}$. Immediate action to reduce exposure is indicated if the average air concentration exceeds $0.2 \mathrm{mg} \mathrm{U} / \mathrm{m}^{3}$ over a 40 -h workweek, 
$0.15 \mathrm{mg} \mathrm{U} / \mathrm{m}^{3}$ over two consecutive workweeks, $0.1 \mathrm{mg} \mathrm{U} / \mathrm{m}^{3}$ over a period of one month, or $0.05 \mathrm{mg} \mathrm{U} / \mathrm{m}^{3}$ over $3 \mathrm{mo}$ (Figure D.1). In each case the investigation level is 0.3 times the immediate action level.

\section{D.1.3.3. Sensitivity of the Committed Effective Dose to the Choice of Tissue Weighting Factors}

An action level as defined in the present report is the smaller of two derived values, one based on primary guidance for avoidance of chemical toxicity and the other based on primary guidance for limiting potential effects of radiation. Each of the radiologically based values is inversely proportional to the committed effective dose coefficient for inhalation of a selected form of uranium and a selected particle size and is based on a target dose of $0.02 \mathrm{~Sv}$ (annual committed effective dose) for derivation of an investigation level and $0.05 \mathrm{~Sv}$ for derivation of an immediate action level.

The committed effective dose coefficients used in this report are based on tissue weighting factors recommended in ICRP Publication 60 (1991) (Column 3 of Table D.2). These tissue weighting factors updated the weighting factors recommended in ICRP Publication 26 (1977) and applied in the current version of 10CFR20 (Column 2 of Table D.2). The recently published ICRP Publication 103 (2008) provides another update of the ICRP's tissue weighting factors (Column 4 of Table D.2). It could be argued that tissue weighting factors from ICRP Publication 26 should be used to develop guidance values for exposure to uranium in the workplace because ALIs and DACs in the current version of 10CFR20 are based on those weighting factors. On the other hand, an argument could be made for applying the ICRP's most recently recommended tissue weighting factors, i.e., those from ICRP Publication 103.

An analysis was performed to determine the sensitivity of committed effective dose coefficients E for inhaled ${ }^{234} \mathrm{U},{ }^{235} \mathrm{U}$, and ${ }^{238} \mathrm{U}$ to the set of tissue weighting factors applied. In the following, the abbreviations $\mathrm{E}_{26}, \mathrm{E}_{60}$, and $\mathrm{E}_{103}$ are used for committed effective dose coefficients based on tissue weighting factors given in ICRP Publications 26, 60, and 103, respectively, and the biokinetic models applied in this report.

As illustrated in Table D.4 for inhaled ${ }^{234} \mathrm{U},{ }^{235} \mathrm{U}$, or ${ }^{238} \mathrm{U}$ of Type F, M, or S and particle size $5 \mu \mathrm{m}$ AMAD, committed effective dose coefficients for uranium isotopes are not highly sensitive to the choice of tissue weighting factors. This is because the weighting factors in ICRP Publications 26, 60, and 103 are reasonably similar for those tissues that tend to dominate $\mathrm{E}_{26}$, $\mathrm{E}_{60}$, and $\mathrm{E}_{103}$ for uranium isotopes. For example, the lung dose largely determines $\mathrm{E}_{26}, \mathrm{E}_{60}$, and $\mathrm{E}_{103}$ for inhalation of Type $\mathrm{M}$ or Type $\mathrm{S}$ material, and the lung is given the same weight $(0.12)$ in all three ICRP documents. The most important differences among the three sets of tissue weights are the weights assigned to Bone surface (0.03 in ICRP Publication 26 and 0.01 in ICRP Publications 60 and 103) and differences in the definitions and weights of Remainder tissues. In ICRP Publication 26 the weight 0.3 is given to the dose to Remainder tissues, defined as the average dose to the five remaining tissues receiving the highest doses. In ICRP Publication 60, the weight 0.05 is applied to the mass-weighted average dose to adrenals, brain, extrathoracic airways, small intestine, kidneys, muscle, pancreas, spleen, thymus, and uterus except when the "splitting rule" applies. The splitting rule states that if one of the tissues in this Remainder group 
receives a dose in excess of that received by any of the 12 tissues for which weighting factors are specified (Table D.2), a weighting factor of 0.025 is applied to that tissue and 0.025 is applied to the mass-averaged committed equivalent dose in the rest of the Remainder tissues. In ICRP Publication 103, the weight 0.12 is applied to the average of doses to adrenals, extrathoracic (ET) region, gallbladder, heart, kidneys, lymphatic nodes, muscle, oral mucosa, pancreas, prostate, small intestine, spleen, thymus, and uterus/cervix. For inhaled ${ }^{234} \mathrm{U},{ }^{235} \mathrm{U}$, or ${ }^{238} \mathrm{U}$, differences in the definitions of dose to Remainder tissues and the weighting factors for Remainder tissues account for virtually all of the differences between $\mathrm{E}_{60}$ and $\mathrm{E}_{103}$.

Table D.4 Comparison of committed effective dose coefficients $E_{26}, E_{60}$, and $E_{103}$ for inhaled ${ }^{234} U,{ }^{235} \mathrm{U}$, or ${ }^{238} \mathrm{U}(5 \mu \mathrm{m}$ AMAD) based on tissue weighting factors from ICRP Publications 26, 60, and 103, respectively ${ }^{a}$

\begin{tabular}{ccccc}
\hline \multicolumn{2}{c}{ Absorption type } & Ratio $\mathbf{E}_{\mathbf{2 6}}: \mathbf{E}_{\mathbf{6 0}}$ & Ratio $\mathbf{E}_{\mathbf{1 0 3}}: \mathbf{E}_{\mathbf{6 0}}$ & Ratio $\mathbf{E}_{\mathbf{2 6}}: \mathbf{E}_{\mathbf{1 0 3}}$ \\
\hline${ }^{234} \mathrm{U}$ & & & \\
& $\mathrm{F}$ & 1.69 & 1.03 & 1.64 \\
& $\mathrm{M}$ & 1.06 & 1.07 & 0.99 \\
& $\mathrm{~S}$ & 0.73 & 1.40 & 0.52 \\
${ }^{235} \mathrm{U}$ & & & & \\
& $\mathrm{F}$ & 1.69 & 1.03 & 1.64 \\
& $\mathrm{M}$ & 1.06 & 1.07 & 0.99 \\
& $\mathrm{~S}$ & 0.72 & 1.41 & 0.51 \\
${ }^{238} \mathrm{U}$ & & & & \\
& $\mathrm{F}$ & 1.68 & 1.03 & 1.64 \\
& $\mathrm{M}$ & 1.06 & 1.07 & 0.99 \\
& $\mathrm{~S}$ & 0.72 & 1.42 & 0.51 \\
\hline
\end{tabular}

${ }^{a}$ The biokinetic models described in Section 3 are applied in each case.

\section{D.1.3.4. Title 10 Code of Federal Regulations (CFR) Part 20, Standards for Protection Against Radiation}

These Nuclear Regulatory Commission regulations include consideration of uranium chemical toxicity at 10 CFR 20.1201 (e). Licensees are required to limit the soluble uranium intake by an individual to 10 milligrams in a week in consideration of chemical toxicity. Assuming a 50 week work-year, this level would result in a limit of $500 \mathrm{mg} \mathrm{U}$ intake in a year. In this report we calculate the intake rate of a soluble form of uranium that would result in an equilibrium concentration of $0.3 \mu \mathrm{g} \mathrm{U} / \mathrm{g}$ kidney (the investigation level) to be $36.5 \mathrm{mg} \mathrm{U} / \mathrm{y}$ (Section 5.3.1), or about a factor of 14 lower than the limiting value in 10 CFR 20. The reference immediate action level of $1.0 \mu \mathrm{g} \mathrm{U} / \mathrm{g}$ kidney corresponds to an inhalation rate of $120 \mathrm{mg} \mathrm{U} / \mathrm{y}$.

A limit on ingestion of soluble uranium implied by 10 CFR 20.1201 can be compared with the present report also, by translating an ingestion intake of $10 \mathrm{mg} \mathrm{U}$ per week to an implied kidney $\mathrm{U}$ concentration based on current biokinetic models for uranium. Fractional uptake from the 
alimentary tract to blood is assumed to be 0.02 for relatively soluble forms of uranium in food or drink (Section 3.2.4). From Table 3.9, continuous input to the blood of $1 \mu \mathrm{g} \mathrm{U} / \mathrm{d}$ results in approximately $0.01 \mu \mathrm{g} \mathrm{U} / \mathrm{g}$ kidney after 100 days. Thus, the expected concentration in the kidneys from ingestion at the 10 CFR 20.1201(e) limit, $10 \mathrm{mg}$ U/week intake, and assuming a 5day workweek, results in a daily intake of 2,000 $\mu \mathrm{g} \mathrm{U}$. Scaling the results from Table 3.9 results in $20 \mu \mathrm{g} \mathrm{U} / \mathrm{g}$ kidney, which is twenty times the reference primary guidance level in this report.

\section{D.2. U.S. Department of Energy Regulation and Technical Standard}

\section{D.2.1. 10 CFR 851.23 "Safety and Health Standards."}

In 10 CFR 851.23 (a) (3) and (9) DOE adopts the OSHA generated requirements for U. OSHA's uranium limits are given in 29 CFR 1910.1000 Table Z-1 and are summarized below in Section D.3 of the present report. Specifically, the DOE regulations state:

(a) Contractors must comply with the following safety and health standards that are applicable to the hazards at their covered workplace:

...(3) Title 29 CFR, Part 1910, "Occupational Safety and Health Standards," excluding

29 CFR 1910.1096, "Ionizing Radiation.” [See Section D.3. below for quantitative values.]

...(9) American Conference of Governmental Industrial Hygienists (ACGIH),

"Threshold Limit Values for Chemical Substances and Physical Agents and Biological Exposure Indices," (2005) (incorporated by reference, see $§ 851.27$ ) when the ACGIH Threshold Limit Values (TLVs) are lower (more protective) than permissible exposure limits in 29 CFR 1910. When the ACGIH TLVs are used as exposure limits, contractors must nonetheless comply with the other provisions of any applicable expanded health standard found in 29 CFR 1910.

\section{D.3. U.S. Department of Labor, Occupational Safety and Health Administration (OSHA),}

The Occupational Safety and Health Standards address toxic and hazardous substance, and, in particular, limits for airborne uranium concentrations in air are listed in Table Z-1 Limits for air contaminates at 29 CFR 1910.1000. For soluble uranium compounds the Permitted Exposure Limit (PEL) is $0.05 \mathrm{mg} / \mathrm{m}^{3}$ for an 8-hour Time Weighted Average (TWA). For insoluble uranium compounds the PEL is $0.25 \mathrm{mg} / \mathrm{m}^{3}$. These PELs are equal to $50 \mu \mathrm{g} / \mathrm{m}^{3}$ and $250 \mu \mathrm{g} / \mathrm{m}^{3}$, respectively.

In this report the investigation levels for any mixture of ${ }^{234} \mathrm{U},{ }^{235} \mathrm{U}$, and ${ }^{238} \mathrm{U}$ are $15 \mu \mathrm{g} / \mathrm{m}^{3}$ for relatively soluble mixtures, $61 \mu \mathrm{g} / \mathrm{m}^{3}$ for moderately insoluble mixtures and $585 \mu \mathrm{g} / \mathrm{m}^{3}$ for insoluble mixtures, based on an average over a 1-y period (Table 5.2). Table 5.1 shows that the air concentrations for investigation levels are not constant. Rather, they change from high to low as the exposure time increases from one 40-hour work week to over 3 months. The constant OSHA limits do not appear to account for the build-up of uranium in the kidneys as the exposure time increases in an occupational setting. 


\section{D.4. American Conference of Governmental Industrial Hygienists (ACGIH) Threshold}

Limit Values (TLVs) for chemical substances and physical agents and Biological Exposure Indices (BEIs), 2011.

The TLV-TWA values are given for both soluble and insoluble uranium as $0.2 \mathrm{mg} / \mathrm{m}^{3}$, and the ceiling is $0.6 \mathrm{mg} / \mathrm{m}^{3}$. These values are unchanged from the 2005 edition that was incorporated into DOE regulations and are equal to $200 \mu \mathrm{g} / \mathrm{m}^{3}$ and $600 \mu \mathrm{g} / \mathrm{m}^{3}$, respectively. The comments on comparisons above under Section D.3., above, for OSHA apply here as well. 